

\section{Impact Study of}

\section{Soil Health Card Scheme}

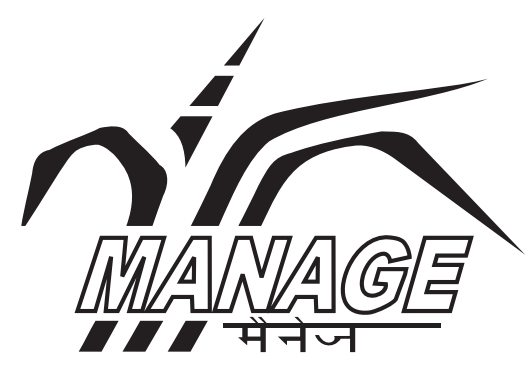

NATIONAL INSTITUTE OF AGRICULTURAL EXTENSION MANAGEMENT (MANAGE)

(An organisation of the Ministry of Agriculture and Farmers Welfare, Govt. of India)

Rajendranagar, Hyderabad - 500 030, Telangana State, India

www.manage.gov.in 
Citation: Reddy A Amarender (2018) Impact Study of Soil Health Card Scheme, National Institute of Agricultural Extension Management (MANAGE), Rajendranagar, Hyderabad 500030, Telangana State, India. 106 pp. 
वी. उषा रानी, मा.ए.स सहानिदेशक

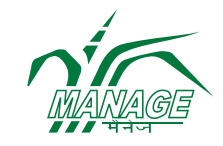

V. Usha Rani, IAS

Director General

\section{Foreword}

Government of India introduced Soil Health Card (SHC) Scheme to facilitate farmers for better understanding of soil and Integrated Nutrient Management (INM). It is a well known fact that soil is the basis for agriculture and protecting the soil is the basic responsibility of every farmer to sustain agriculture. Unfortunately, quality and yields of agriculture produce is not a expected level due to deficiency of various nutrients. At the same time, there is excessive usage of certain nutrients. All this is happening as farmer is not fully aware of various physical, chemical and microbial activities in soil and due to this, farmers are unable to apply fertilizers in balanced and required quantities.

The Department of Agriculture, Cooperation and Farmers Welfare assigned MANAGE to undertake study of implementation of Soil Health Card Scheme. The study brought out important aspects of whole gamut of activities starting from collecting soil sample, analysis and interpretation of data.

I congratulate Dr. Amarender Reddy, Director (Monitoring \& Evaluation) and Principal Investigator and his team for the hard work they have rendered by taking up this study. I hope the study will further strengthen the scheme and will have impact on the farmers knowledge on soil and application of fertilizer in a balanced manner.

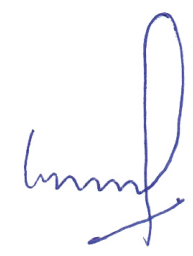

(V. Usha Rani)

\section{राष्ट्रीय कृषि विस्तर प्रबंध (मैनेज)}

(कृषि एवं. किसान कल्याण मंत्रालय, भारत सरकार का संगठण, राजेन्द्रनगर, हैदराबाद-500 030, टी. एस. भारत)

NATIONAL INSTITUTE OF AGRICULTURAL EXTENSION MANAGEMENT (MANAGE)

(An organization of Ministry of Agriculture and Farmers Welfare, Government of India

Rajendranagar, Hyderabad-500 030, T.S. India

Ph: +91(40) 24015253 (0), Fax: 040-24015388

E-mail: dgmanage@manage.gov.in, Web: manage.gov.in 



\section{Acknowledgement}

The study on "Impact of Soil Health Card Scheme" has been carried out at the National Institute of Agricultural Extension Management (MANAGE), Rajendranagar, Hyderabad, as suggested and sponsored by the Ministry of Agriculture and Farmers Welfare, Government of India.

We have benefited immensely from various scholars and officials from different government departments while carrying out this study. At the outset, we would like to thank Smt. V Usha Rani, IAS, Director General of our institute as well as Smt. Rani Kumudhini, IAS then Joint Secretary, INM, Ministry of Agriculture and Farmers Welfare, Government of India for their constant encouragement and support for undertaking this impact study. We are grateful to Smt. Neerja, IAS, Joint Secretary, INM, Ministry of Agriculture and Farmers Welfare, Government of India and Dr. Chaudhary, Additional Commissioner, INM, Department of Agriculture and Cooperation and Farmers Welfare for continuous support and guidance.

We are grateful to directors and joint directors and other officials from different state department of agriculture for their cooperation during the field survey and later interactions in focus group interactions for sharing their valuable suggestions. We thank Dr. Ratna Reddy, Dr. Padma Raju, ex Vice Chancellor, PJTSAU, Rajendranagar, Dr. CP Chandrashekar, former dean, PJTSAU for their guidance and active involvement.

We thank our colleagues in MANAGE for their support and encouragement while carrying out the study.

We are also thankful to the officials and sample farmers in the study area. The study would not have reached this stage without the active co-operation of the sample households, who provided all the required data for the study without any hesitation and expectation. We thank each one of them for their invaluable support.

\section{A Amarender Reddy}

Principal Investigator 


\section{Abbreviations}

ASCI Agriculture Skill Council of India

CACP Commission for Agricultural Costs and Prices

DSS Decision Support System

EC Electrical Conductivity

FAO Food and Agriculture Organization

FC Forward Class

FPCs $\quad$ Farmer Producer Companies

GIS Geographic Information System

GPS Global Positioning System

ICAR Indian Council for Agricultural Research

ICRISAT International Crops Research Institute for the Semi-Arid Tropics

IFPRI International Food Policy Research Institute

IISS Indian Institute of Soil Science

IPCC Intergovernmental Panel on Climate Change

ISRO Indian Space Research Organization

ITPS Intergovernmental Technical Panel on Soils

KVK Krishi Vigyan Kendra

NABARD National Bank for Agriculture and Rural Development

NAPCC NationalAction Plan on Climate Change

NGO Non-Governmental Organization

NMSA National Mission for Sustainable Agriculture

OBC Other Backward Caste

OC Organic Carbon

PPP Public Private Partnership

RAU RajendraAgricultural University

S\&MF Small and Marginal Farmers

SAU State Agricultural University

SC Scheduled Cast

SHC Soil Health Card

ST Scheduled Tribes

STCR Soil Test Based Crop Response

STL Soil Testing Labs

UNCCD United Nations Convention to Combat Desertification

UNFCCC United Nations Framework Convention on Climate Change

WS World Soil Charter 


\section{Contents}

Executive Summary

Page no:

Chapter 1: Introduction

Chapter II: Soil Health in India - Review of Experience

2.1: Soil Health in India

5

2.2: Soil Nutritional Status

5

2.3: Soil Organic Carbon

6

2.4: Soil Health Card to improve Soil Health 7

Chapter III: Policy interventions over the years: International and National $\quad 10$

3.1: Global Policies

3.2: National Policies

Chapter IV: Objectives and Methodology

4.1: Objectives

4.2: Methodology

4.2.1: Selection of States, Districts \& Blocks 13

4.2.2: Structure of Data from Farmers 15

4.2.3: Indicators of inputs of Soil Health Card (SHC) scheme 15

4.2.4: Indicators of activities under SHM 15

4.2.5: Indicators of outputs of the Scheme 16

4.2.6: Indicators of outcomes 16

4.2.7: Indicators of Socio-economic impact 16

4.2.8: Information from key stakeholders \& secondary data 16

Chapter V: Soil Health card Scheme: Design, Coverage \& Impact 17

5.1: SHC Design and Status (inputs/activities/and outputs) 17

5.2: Status of SHC (Financial and human resource allocation) 27

5.3: Farmers feedback on the Design 33

5.4: Design in different States 37

5.5: Improvements required in the SHC Scheme design 38

5.6: Socio-economic characteristics of the sample farmers 41

5.7: Awareness, utilization and outputs under the SHC scheme 42

5.8: Farmers perception and source of information about SHC 48

5.9: Outcomes (Input use and Cost per hectare) of the SHC scheme 57

5.10: Success stories and potential benefits of the SHC scheme 62

5.11: State wise crop wise fertilizer consumption 63 
Chapter VI: Policy Recommendations

6.1 Soil Sampling related (SHC design)

6.2 Soil Health Indicators (SHC design)

74

6.3 Soil Testing Infrastructure

6.4 Soil Extension

6.5 Policy related

References

Annexure-1: Feedback from agricultural officers on status of SHC and improvement needed

Annexure-2: Soil Health \& Soil Testing: Some Practical Issues

Annexure-3: Field Observations compiled across states

Appendix-1: Review of Recent Studies

Appendix -2: Regression Analysis: Determinants of Performance indicators of SHC Scheme (District Level)

Appendix-3: Farmers Questionnaire 


\section{List of Tables}

S.No. Particulars

Pg.Nos.

Table 1: Consumption of Fertilisers in million tonnes in India

Table 2 Soil Quality and Quantity Indicators 12

Table 3 Details of Sampling Framework 14

Table 4A Financial Allocations and Expenditure $\quad 27$

Table 4B Zone wise analysis of funds allocation, release and utilisation $\quad 28$

Table 5: Infrastructure (number of Labs) in 2016-17 29

Table 6A: $\quad$ Samples entered, farmers covered, samples tested and SHCs printed (Cycle-1) 31

Table 6B: $\quad$ Samples entered, farmers covered, samples tested and SHCs printed (Cycle-2) 32

Table 7A: Indicators mentioned in SHCs in different states of USA

Table 7B: Indicators mentioned in SHCs in other countries 36

Table 8: $\quad$ Basic Features of the Sample Households (HH) 41

Table 9: $\quad$ Basic Features of the Sample Households (HH) by irrigation status 41

Table 10: $\quad$ Zone wise awareness about SHC $\quad 42$

Table 11: $\quad$ Farm Size Class wise awareness about SHC $\quad 43$

Table 12: $\quad$ Social group wise awareness about SHC 43

Table13: $\quad$ Awareness about SHC in developed and less developed states $\quad 44$

Table 14: Awareness about SHC by Irrigation Status of the Farmers 45

Table 15: $\quad$ Participation of Farmers in SHC Activities across Regions 46

Table 16: Participation of Farmers in SHC Activities across States 46

Table 17: Participation of Farmers in SHC Activities across Size Classes 47

Table 18: $\quad$ Participation of Farmers in SHC Activities across Social Groups 47

Table 19: $\quad$ Participation of Farmers in SHC Activities across irrigated area groups $\quad 47$

Table 20: $\quad$ Farmers perception about SHC across Regions 48

Table 21: Farmers opinion about SHC across Size Classes 49

Table 22: Farmers opinion about SHC in developed and less developed states 50

Table 23: Farmers opinion about SHC across Irrigation Categories 50

Table 24: Number of plots covered in soil testing across Zones 51

Table 25: Number of plots covered in soil testing across Size Classes. 51

Table 26: Number of plots covered in soil testing 52

Table 27: Number of plots covered in Irrigation Groups $\quad 52$

Table 28: Zone wise source of information about SHC content 53

Table 29: $\quad$ Source of information about SHC content across size classes $\quad 54$

Table 30: $\quad$ Source of information about SHC content by state groups 54

Table 31: Source of information about SHC content by level of irrigation 54

Table 32: Farmers Perceptions about SHC across Zones 55

Table 33: Farmers Perceptions about SHC across Size Classes 55

Table 34: Farmers Perceptions about SHC across Social Categories 56

Table 35: Farmers Perceptions about SHC across States 56 
Table 36: Farmers Perceptions about SHC Irrigated Groups

Table 37: Impact of SHC on fertilizer use, costs and crop yields 58

Table 38: Impact of SHC on fertilizer use, costs and crop yields by farm size category 59

Table 39: Status according to longevity (period of holding SHC) (cotton) 60

Table 40: $\quad$ Status according to longevity of card (Paddy) 60

Table 41: $\quad$ Status according to longevity of card (soybean) 60

Table 42: $\quad$ Status according to longevity of card (pigeon pea) 61

Table 43: $\quad$ Status according to longevity of card (Wheat) 61

Table 44: Success stories of reduction in fertilizer use $\quad 62$

Table 45: Analysis of Fertilizer use by crop across states (CACP data) 2013-14 64

Table 46: $\quad$ Fertilizer use (kg/ha) in 2014-15 66 


\section{List of Maps}

S.No. Particulars

Pg.Nos.

Map 1: $\quad$ Status of Nitrogen and Zinc availability in Indian soil(Source: Economic Times)

Map 2: $\quad$ Status of Phosphorus and Iron availability in Indian soil

Map 3: $\quad$ Status of Potassium, Copper and Manganese availability in Indian soil

Map 4: $\quad$ State Wise Consumption of Fertilizers

Map 5: Changing chemical composition of soils

Map 6: State wise samples collected per 1000 ha.

Map 7: $\quad$ State wise samples collected per 1000 cultivators

Map 8: $\quad$ State wise samples tested per 1000 ha

Map 9: $\quad$ State wise samples tested per 1000 cultivators

Map 10: State wise SHCs printed per 1000 ha.

Map 11: State wise SHCs printed per 1000 cultivators

Map 12: State wise SHCs distributed per 1000 ha

Map 13: State wise SHCs distributed per 1000 cultivators

Map 14: District wise samples collected per 1000 ha

Map 15: District wise samples tested per 1000 ha

Map 16: District wise SHCs printed per 1000 ha

Map 17: State wise number of soil testing laboratories

Map 18: State wise Soil Testing Labs per Million Hectares

Map 19: District wise STLs per million cultivators 


\section{List of Figures}

S.No. Particulars

Pg.Nos.

Fig. 1: Measure of Soil Health

Fig. 2: $\quad$ State wise Fertilizer use (kg/ha) and N:K Ratio

Fig. 3: Progressive expansion in the occurrence of nutrient deficiency

Fig. 4: $\quad$ Fields effected by alkalinity

Fig.5: Importance of including water test in the SHC

Fig.6 Landholding wise awareness about SHC

Fig.7 Method of Soil Sample Collection

Fig.8 Awareness about SHC Scheme

Fig.9 Soil sampling equipment

Fig. 10 Percentage of farmers in SHC activities and perception

Fig. 11 Methods for evaluating Soil Nutrient Status

Fig. 12 Number of plots covered for soil testing

Fig. 13 Number of plots covered in developed and less developed states

Fig. 14 Main Source of Information (\%)

Fig. 15 Farmers perceptions about SHC across social categories

Fig. 16 Farmers perceptions about SHC across States

Fig. 17 Soil Test Interpretation Categories

Fig. 18 Azolla- a potential source of bio fertilizer

Fig. 19 Soil Test Crop Response Based Fertilizer Recommendation System

Fig. 20 Soil Test Crop Response Based Fertilizer Recommendation System 


\section{Executive Summary}

Soil health and fertility are the basis for gaining sustainable profit through higher productivity by the farmers. Using optimal doses of fertilisers and cropping pattern as per the scientific recommendations is the first step towards sustainable farming. Soil testing is a science-based and time-tested tool for assessment of the soil fertility status and soil ailments and nutrient amendment recommendations. Soil testing, as a tool for judicious fertiliser use, works on the principle of profitability, which means if all other factors of production are optimum and none of them are limiting, there is a high probability of obtaining a more profitable response to applied nutrients based on soil testing than those applied on an ad hoc basis.

In India, the current consumption of NPK ratio is 6.7:2.4:1, which is highly skewed towards nitrogen as against the ideal ratio of 4:2:1. India is spending nearly Rupees Seventy thousand crore on fertiliser subsidy every year. According to the estimates, subsidy amount is about Rs. 5,000/ha of net cropped area and about Rs. 5,100/farmer, resulting in excessive use of fertilisers, especially NPK, at the cost of micro nutrients and manure. Hence, there is a need for balanced use of fertilisers. Keeping this in mind, the Government of India introduced Soil Health Card Scheme across India (GoI, 2017).

On December 5, 2015, the Ministry of Agriculture introduced the Soil Health Card scheme. It was approved for implementation in the remaining period of 12th plan. SHC will be provided to all farmers in the country at an interval of two years to enable the farmers to apply recommended doses of nutrients based on soil test values for improved and sustainable soil health and fertility, low costs, and higher profits.

Under the SHC scheme, cropped area was divided into grids of 10 ha for rainfed and 2.5 ha for irrigated. One soil sample from each grid was to be taken, and the test results were to be distributed to all the farmers whose lands fell under the grid. Based on the grid system, of the total 14.1 crore hectare of net cropped area, 73 lakh grid samples were to be collected to cover 7.3 crore ha in rainfed areas and 2.7 crore grid samples were to be collected to cover 6.8 crore ha irrigated land. That is, a total of 3.46 crore grid samples in two years (1.73 crore grid samples per year) and an average of 25,000 grid samples per district/year or 29 grid samples per village/year. With this, all 11 crore farmers will be covered in two years. Every year, 5.2 crore farmers need to be covered.

Under cycle 1, 2.54 crore samples were collected, 2.36 crore samples tested, 9.62 crore soil health cards printed, but only 9.33 crore SHCs distributed. This indicates that $100 \%$ target was achieved in sample collection, $93 \%$ of the target was achieved in soil testing, but only $80 \%$ of the target was achieved in SHC printing. 97\% of the SHCs printed were distributed among the farmers as on September 24, 2017. Cycle 2 has already started in many states. Overall, the progress of the SHC scheme in terms of coverage is satisfactory, and now we have to focus more on the quality of soil sample collection and testing and timely distribution of SHCs to farmers. However, the progress is highly skewed. Some states, such as Karnataka, TN, Chhattisgarh, UP, Maharashtra, Telangana, and AP, were better performers compared to other states. 


\section{Objective of the impact study}

As the SHC scheme has completed more than 2 years of implementation, the ministry has initiated a nationwide impact assessment with the following objectives:

o To examine the design of the SHC scheme in terms of planning, implementation, inputs (staff, financial, and other resources), activities (trainings, lab established, and strengthened), outputs (SHCs printed and distributed to farmers).

o To assess the modalities of delivery of the SHC scheme regarding procurement, sample collection, testing, SHC printing, and disbursal.

o To assess the level of utilisation of SHCs by the farmers across farm size classes in irrigated and rainfed situations.

o To assess the impacts of the SHC scheme on judicious use of fertilisers, bio-fertilisers, organic fertilisers, soil health, cropping choice, cost reduction, farm profitability, and sustainability.

o To provide recommendations for improvement of the overall design of the programme.

\section{Methodology}

Both quantitative and qualitative approaches were adopted to achieve the objectives of the study. Qualitative information was in the form of stakeholder interviews across the states under the study, expert opinion gathering at the national and state level workshops, and interactions with the progressive farmers and agricultural officers. At the quantitative level, both secondary and primary data was collected at the national, state, and farmer levels. Secondary data mostly pertains to collection and analysis of financial and physical achievements of the SHC scheme over the years, infrastructure availability, coverage of SHCs across the states, etc. Besides, information at the international level was collected for some selected countries to see the best practices in the design of soil health cards.

The secondary data was analysed for all the states, while primary data was analysed for 16 states of India representing all agro-climatic zones. A systematic sample was drawn for the impact assessment at the farmer level. Care was taken to represent the whole country and its agro-climatic conditions. A structured questionnaire was canvassed among 3,184 sample farmers across 199 villages in 16 states. In addition, focus group discussions were conducted in each village in order to get feedback from the key informants, farmers not covered in individual surveys, and farmers who had not received their soil health card. All indicators collected from the field survey were classified as inputs (financial and physical inputs under the project), activities (different activities organised under the scheme), outputs (actual outputs of the project), outcomes (whether generated outputs were utilised by the farmers), and impacts (what are the ultimate benefits to the farmers); they're listed here. The analysis was carried out across zones/states and completed by the date of receiving SHC by the farmers, i.e., those who received it more than a year back and those who received it recently. This would help understand the long-term impacts and provide insights into whether agriculture development helps better awareness and demand for SHC. 


\section{Main Findings}

It may be noted that the analysis is based on the representative, though limited, sample size across regions. This is too short a time for the scheme (only two-years old) to carry out a full-fledged impact assessment. The present analysis provides insights into the direction and cautions about any shortcomings. While the following conclusions and recommendations are based on the analysis, the weakness of the assessment needs to be kept in mind.

$\checkmark$ Given the short duration of the scheme, awareness levels are good. . At the same time, participation of farmers in meetings and exposure visits is not high. Awareness campaigns need to be organised on the content of SHCs, use of recommended practices, reduction in fertiliser use, and costs and increase in profitability.

$\checkmark$ There is no apparent or significant bias against socio-economically vulnerable sections. In contrast, small and marginal farmers benefit more in some cases.

$\checkmark$ There is some reduction in fertiliser use, especially nitrogen and increase in bio-fertilisers and other micro-nutrients' use. This is a good sign as the N:P:K ratio was highly skewed towards nitrogen. Costs were reduced due to low fertiliser use. Crop yields also increased for a majority of the crops, although only moderately.

$\checkmark$ A significant impact is the increase in the use of gypsum and other micro nutrients to some extent.

$\checkmark$ There is a need to strengthen the SHC-related extension services to provide better advisories.

$\checkmark$ Two-thirds of the sample farmers indicated that SHC is beneficial, which is encouraging given the short span of the programme.

$\checkmark$ The main complaint from the farmers is the timeliness of providing the results. This, however, is linked to the infrastructure (soil testing labs) and human resources. However, after the introduction of the SHC scheme, the time lag has significantly reduced. Results need to be disseminated before the sowing season so that farmers will practice recommended crop choice and fertilisers.

$\checkmark$ It is important to address these issues to gain confidence of the farmers in adoption of the fertilisers as per the recommendations included in the SHC.

$\checkmark$ The scheme has poor backing from infrastructure and human resources, with significant gaps. Although some southern and western states performed better, in some states, even the allocated resources are not being spent or utilised due to lack of capacities. This should be of high priority in the immediate future.

$\checkmark$ Proactive regions seem to be better in this regard.

$\checkmark$ Lack of capacities with regard to skilled personnel and STLs affects the quality of services, which in turn affects the credibility of the scheme and needs immediate attention.

$\checkmark$ Results need to be provided in time so that farmers can benefit in a better way. 


\section{Level of Utilisation and Impact of the SHC Scheme}

1. About $66 \%$ of the farmers are able to understand the content of the SHC, about $57 \%$ mentioned that the recommendations are suitable for their farms, and about 53\% are able to follow recommendations.

2. The SHC scheme is inclusive in nature; small and marginal farmers are proactive in the adoption of recommendations based on SHC.

3. There was a reduction in the use of urea and DAP by 20 to $30 \%$ in paddy and cotton in some states, resulting in decreased cost of cultivation. The reduction in the cost of cultivation ranged between Rs. 1,000 and Rs. 4,000 per acre.

4. The use of micro-nutrients (especially gypsum) was slightly increased after SHC distribution.

5. There was a significant increase in yield for farmers who practiced recommended practices as per the SHC.

6. With decrease in the cost of cultivation and increase in yields, net incomes of the farmers increased between 30 and $40 \%$ after the SHC scheme.

\section{Constraints of the SHC Scheme}

1. Some farmers complained that the soil test values are not representative of their fields and that the field staff did not collect the soil samples in their presence. To build trust, samples need to be collected in the presence of GRID farmers.

2. Uniform soil GRIDS of 10 ha for rainfed and 2.5 ha for irrigated should be re-examined. The grid size should be determined based on the soil variability index (soil variogram). If variability is high, GRID size should be less and vice versa.

3. Soil variogram needs to be developed at each block level to determine the GRID size at the block level.

4. Many farmers are unable to understand the content and hence are unable to follow the recommended practices.

5. Only $44 \%$ of the farmers mentioned that the extension officers explained the content.

6. SHC distribution and awareness campaigns needs to be arranged before the sowing season so that farmers can practice recommended crop choice and fertilisers.

7. Awareness campaigns need to be organised for the use of SHC in reduction of fertiliser use and costs and increase in yields.

8. Many farmers feel that SHC should also mention one or two physical and micro-biological indicators (such as soil texture, water holding capacity, and water quality and bacterial content).

9. There is a need to identify best practices in soil sample collection (predetermined DRID apps practised in Punjab and TN) and testing for scale-up.

10. Development of GIS-based soil fertility maps at the village/block level and wider publicity through wall posters and display boards in village panchayats should be promoted.

11. The Government should ensure availability of recommended fertilisers and bio-fertilisers at the village level at reasonable prices. 


\section{Soil - Sampling - related (SHC Design ) Improvement}

- There is a need to identify best practices in soil sample collection and testing by examining across countries and different state governments practices. There is also a need for coordination and cooperation.

- The existing uniform grid of 10 ha for drylands and 2.5 ha for irrigated lands does not take local soil variability into consideration. Grid size should be variable based on the soil variability index and should be decided at least at the block level based on soil heterogeneity, fertility maps, cropping pattern, irrigation facilities, and remote sensing maps. If the soil is more variable, grid size should be reduced and vice versa. Sampling errors need to be reduced using variogram. There should be a separate cell to monitor and recommend grid size across the country. This will also reduce cost, money, and manpower and increase the relevance of recommendations to farmers. In order to gain the credibility of the farmers, at least one sample from each farmer should be included where soil variability is high.

- Soil variograms needs to be developed at each block level. Based on the soil variability, the grid size can be determined. Variogram gives information about spatial pattern of continuous soil attributes. The variogram may be used as a critical input to decide required soil samples to be collected based on the soil variability index. More soil samples should be collected if the blocklevel soil variability index was high and vice versa. Variogram is a tool to investigate and quantify the spatial variability of soil properties. The geostatistical literature shows that the following soil quality indicators were found to be the most important for variogram analysis, and they can also be considered by the ministry. The available data with Indian Institute of Soil Science, Satellite maps of remote sensing agency of ISRO, and Land use planning data can be used to estimate block-level soil variograms.

- The following soil indicators may be considered to construct block-level soil variograms: (1) Soil Colour, (2) Slop, (3) Sand (\%), (4) Silt (\%), (5) Clay (\%), (6) Nitrogen (N), (7) Phosphorus (P), (8) Potassium (K), (9)Organic Matter (OM), (10) Organic Carbon (OC), (11) pH, (12) Cation Exchange Capacity (CEC), (13) Electrical conductivity (EC), (14) C:N Ratio, (15) percentage of irrigated area, and (16) cropping pattern. The ICAR-Indian Institute of Soil Science (IISC), Bhopal; ICAR-IISWC- Indian Institute of Soil and Water Conservation, National Remote Sensing Agency (NRSA), Hyderabad; and land classification/atlas can be consulted for developing block-level soil variograms.

- Evidence shows that samples collected from $20 \%$ to $30 \%$ of the farmers in a village are enough to get reasonable soil quality for advising farmers, and hence there was no additional benefit in covering each grid of 10 ha in case of dry lands and 2.5 ha in case of irrigated land if the soil was fairly uniform. In some cases, only 20-30 samples/500 ha are sufficient, as is evident from ICRISAT experiments. This, however, needs to be explained to the farmers so that they would take the SHC recommendations seriously. One needs to be mindful of the efforts and resources gone into ICRISAT experiments. 
- Although grids in some states were predetermined in the mobile app (such as in Punjab), in other cases, the procedure that is followed in dividing the cultivated village land into grids is not known to many agricultural officers and needs to be widely disseminated for accurate sampling, and this should be mentioned in the guidelines. Interestingly, Punjab is adopting GIS-tablet grid identification and GPS-based soil sample collection application, which seems to be working well and is likely to solve many field-level sample collection problems. This model should be adopted across all the states after an in-depth understanding (study) of the model.

- High density soil maps need to be developed for increasing precision at the village level.

- There is a need to give appropriate training, easy-to-use sampling tools, and transport to agricultural officers and agricultural extension officers. Incentives need to be provided for scientific sample collection.

- Coordination of agricultural extension officers and farmers needs to be enhanced and extension officers should make sure that most of the grid farmers, if not all, should be present at the time of soil sample collection. This will build farmers' confidence in SHCs.

- It was observed by the study team that in some of the block agricultural offices, soil samples were kept aside for many days and soils were exposed to moisture and weather. After soil sampling, drying should be done within 15-20 days, and grinding, machine sieving, and bottling should be done in time for proper test results. Sample test results should reach farmers before the sowing season. It might be a good idea to limit samples to the capacities. There should be more focus on the quality of soil sample collection and testing rather than coverage, as we have already covered larger areas and farmers with SHCs. This would create demand for soil testing once the credibility of the testing is established.

\section{Improvement in Soil Health Indicators (SHC Design)}

- The whole chain of soil health-plant-health-human health should be taken into account and there is a need for promotion of application of balanced application of soil (macro and micro) nutrients.

- Excess application of urea results in accumulation of nitrate in the soil and water is becoming a huge environmental problem in India. Hence, water quality information needs to be included in the SHC.

- The soil health card is more focused on chemical nutrient indicators; among physical and biological properties, only soil colour is included. Some more physical properties, such as slope of the land etc. needs to be incorporated as well.

- Microbial activity and moisture retention activity are essential but missing in SHC. Although soil organic matter is indicated, many soil testing labs are not equipped with the latest tools to measure it.

- At least one or two physical and micro-biological indicators (such as soil texture, water holding capacity, water quality, and bacterial content) need to be incorporated. Soil health index needs to be developed and incorporated into SHC, which indicates the overall health of the soil. 
- Although the basic structure of SHC should be uniform, states should adopt/change as per their agro-climatic zones and needs. Some of the indicators that needs to be included in SHC are (i) cropping history, (ii) water resources (soil moisture), (iii) slope of soil, (iv) depth of soil, (v) colour of soil, (vi) soil texture (bulk density), and (vii) micro-biological activity.

\section{Soil Testing Infrastructure (Design and Delivery)}

- About 1,454 labs exist in India, of which only 700 are equipped with micro-nutrient testing facilities. Although agricultural departments procured about 7,000 mobile kits recently, they are not as good as those in full-fledged labs. Very few labs could take up micro nutrient analysis. They are neither equipped with skilled personnel nor chemicals or functional equipment. The infrastructure is grossly inadequate by any standard, given that 11 crore farmers need to be covered.

- Under the current PPP model, investments in labs are to be done by private companies with an element of subsidy. A competitive bidding process based on technical and financial bids needs to be announced, and companies that quote reasonable cost (per sample) should be selected. The Government will pay on a per-sample basis with the condition that they employ qualified and trained chemists. This model will be successful when there is no strong government presence in soil testing. However, the quality of such reports should be checked at random by authentic agencies.

- About $45 \%$ of the sample farmers are inclined to go to private STLs. At the same time, only 20 $\%$ of the farmers are willing to pay for the services. Hence, one must find ways to support farmers in this regard i.e., direct subsidy to the farmers or private STLs, etc. A competitive PPP model could be explored in this regard, while the government should take up the monitoring of the functioning of these labs more seriously. At the same time, there should be special incentive for Farmer Produce Companies (FPCs) to establish soil testing labs. There is a need for encouraging competition among private companies in setting up and running the soil testing labs so that they maintain quality at a reasonable cost. Institutional modalities could be worked out on how to equip and manage STL within the FPCs frame work.

- Some of the private soil testing labs indicated that the cost of sample collection and testing was up to Rs. 1,000 / sample. Some private companies are charging Rs. 75/element; accordingly, for 12 elements, the total cost will be Rs. 900/sample. The government should be more realistic in fixing the prices for private parties. It should focus more on the quality of the services at an acceptable (market) cost.

- There should be strengthening and upgrading of at least one soil testing lab per district as a stateof-the-art lab, equipped with world class infrastructure and accredited by internationally recognised agencies either in the public or the private sector. So, nearly 700 state-of-the-art labs are needed to act as referral labs and to give broad advice to farmers. The cost per unit will be about Rs. 4-5 crore/unit, with a total of Rs. 2,800 crore. However, if this resulted in Rs. 1,000/ha savings in fertiliser use even if we don't consider the yield increase resulting in a saving of Rs. 14,500 crore in a year for the economy. This could be a more worthwhile investment rather than spending money and providing services that have little value to farmers year after year, i.e., ending up spending more in the long run.

- State-of-the-art district level soil testing labs at a direct level should be equipped with Inductively Coupled Plasma Atomic Emission Spectrometry (ICP-AES), which costs about Rs. 40-50 lakh. These labs should have a 24-hour generator for uninterrupted power supply, 
computer labs with colour printing facility, and air conditioned laboratories. In addition, the lab should have the following equipment for conducting soil testing on a large scale:

KEL PLUS automatic nitrogen determination distiller

Automated Flame Photometer (for Potassium)

Automated Spectrophotometer (for Phosphorus)

Atomic Absorption Spectrophotometer (for $\mathrm{Zn}, \mathrm{Fe}, \mathrm{Mn}, \mathrm{Cu}$ )

Water distillation still (20 lit/hour)

All glass distillation unit (5 litre/hour)

Auto analyser (N\&P)

Automated $\mathrm{pH}$ meter

Automated EC meter

Centrifuge

Auto Burette

- Some soil scientists and agricultural officers are of the opinion that test results of mini-kits (mini-labs) are not accurate enough as that of full-fledged labs. Mini kits need to be standardised and tested for errors in calibrations. A mini kit costs about Rs. 94,800, with which the persample cost comes about Rs. 170-200. Some block agricultural offices received five-six mini kits, but they were not able to utilise them, as they were involved in multiple activities. A mini kit is useful for remote villages and tribal communities and should also be used to measure highly volatile elements such as Nitrogen, which needs more frequent measurement. Mini kits can be used exclusively for Nitrogen estimation in all block/mandal-level offices.

- Soil testing is a specialised and highly skill-oriented job. Frequent transfers of soil testing staff adversely affect the skill development within labs as well as the test results. There is a need to build some permanent staff in the labs who are interested and specialised in soil testing. Field observations indicate that only female officers are interested in working with soil testing labs.

Management of state-of-the-art soil testing labs could be established under the purview of FPC's federations or nodal FPCs at the district level. The governance responsibilities should be handed over to them to be run them as business models. The back of the envelop indicates that establishing a state-ofthe-art lab with a Rs. 6 crore loan from NABARD in each district looks viable given that an average of 25,000 samples need to be collected and processed per year. At Rs. 1,500-2,000 per sample (at half the market price for a detailed soil analysis), the investments will be paid back in less than 2 years. The state department can have a monitoring cell created especially for this purpose, and extension services needs to be geared up to deal with soil health advisories. FPCs should be encouraged to set up demonstration plots to increase demand for soil testing by the farmers.

\section{Soil Health Card Delivery issues}

- SHC recommendations should be accompanied by block-level recommendations. There should be an intermediate solution (based on both village-level soil maps and SHC recommendations) to be able to reach the farmer's level.

- There is a need for demonstration of SHC benefits on an experimental basis in each block by adopting a comprehensive approach (systematic and scientific analysis of soil and water) and adoption of recommended doses. This would have much greater impact than the subsidised and less authentic information. General SHC schemes and model farm initiatives should go together. 
- In many villages, agricultural officers are distributing SHCs in awareness campaigns through village presidents and mandals/blocks' democratically elected representatives. However, in some villages, the village revenue assistant distributes SHC and takes signatures without explaining the content. Whenever SHC is distributed in awareness campaigns and meetings directly, a greater number of farmers feel that they are convinced to use recommended practices. There is a need to follow standard protocol to inform farmers about the recommendations of the $\mathrm{SHC}$ when it is handed over to farmers.

- A specialised body is needed both at the central as well as state level for the management of soils. They should be given the responsibility of monitoring the quality of service by various agencies. This also provides continuity of work by the department.

- Development of GIS-based soil fertility maps at the village/block level and wider publicity through wall posters and display boards in village panchayats should be promoted. Advertisements, slogans, etc. should be developed in local languages to increase awareness. This should be taken up in a campaign mode, i.e., on the lines of anti-smoking/tobacco campaign.

- Many farmers are not aware of the SHC portal. The SHC portal should be more farmer friendly and simplified. A professional body may be employed to design the portal in more farmer friendly and effective manner.

- A simple tool to assess the quantity of urea, DAP, and MoP based on SHC needs to be displayed as wall posters in the villages.

- It should be mandatory to enter fertiliser purchases by the farmers on the soil health card by each fertiliser dealer along with the signature. This will not only increase awareness, but it will also help in adoption as per the recommendation.

\section{Policy Recommendations for Improvement}

- Index of soil health needs to be developed and incorporated into SHC, which indicates the overall health of the soil. Based on the index, soils should be classified as grade A, B, or C. The grades can be updated every SHC cycle based on soil tests. This updating of soil health index may act as an incentive to farmers to put in special efforts to upgrade soil health index, say, from Grade C to Grade A, as grade A soils may fetch higher land rental value for agricultural purposes and get higher land sale price if the land is put for sale compared to soils with grade $\mathrm{C}$.

- All agricultural and rural development schemes should make it mandatory to mention soil health index based on SHC along with Aadhar in their application forms in order to get benefits. The SHC information should be linked to Aadhar and be available for download at e-seva in the public domain.

- If the SHC programme is to be successful, the high fertiliser subsidy for NPK needs to be reduced. Prices should reflect true cost to the economy; only then will farmers have an incentive to use fertilisers judiciously according to the recommendations of the SHC. At the same time, subsidy on use of recommended dose of micro-nutrients, bio-fertilisers, and organic inputs should be encouraged. However, the quality of these inputs supplied on subsidy needs to be 
monitored and stringent punishment needs to be enforced if quality standards are not maintained.

- The government should set up state-of-the-art labs to test the quality of micro nutrients supplied. Accreditation of such labs to national/international standard institutes should be initiated. Supply of phosphorous soluble bacteria should be mandatory along with phosphate fertilisers and rock phosphate such as neem-coated urea. FPCs need to be encouraged to take up the SHC scheme as a business model by setting up state-of-the-art labs at the district level. Since FPCs are already involved in selling fertilisers, they are in a better position to stock all the required (according to $\mathrm{SHC}$ recommendations) fertiliser and micro-nutrient compositions and supply them to individual FPCs across the district.

- There should be some incentives/awards for the farmers who grow green manure and vermicompost and whose soil fertility increased over the years based on Soil Health Card.

- Some incentives should be provided to local bodies that encourage good practices such as recycling crop residues, encouraging common lands for corporates, etc.

- Similarly, incentives can be given to villages when they adopt crop rotation with legumes.

- Innovative techniques such as neem-coated urea (for slow release of fertiliser into the soil) need to be promoted by the government. There should be $45 \mathrm{~kg}$ urea bags instead of $50 \mathrm{~kg}$ ones, which will reduce the loss/excessive use of fertilisers by about $10-20 \%$, especially by small and marginal farmers.

- Soil sample collection, testing, and printing at the district level is significantly positively influenced by fertiliser use, number of bank accounts, net sown area, number of soil testing labs, and households with mobiles.

- Other policies, such as water exploitation, electricity, etc., should be in line so that crop diversity can protect soil health in the long run. 


\section{Chapter - I}

\section{Introduction}

According to the latest estimates, 96.40 Million Hectare (Mha) area of India is undergoing the process of land degradation, i.e., 29.32\% of the Total Geographic Area (TGA) of the country during 2011-13. It increased from 94.53 Mha (28.76\% of the TGA) in 2003-05 (GoI, 2016). The states of Rajasthan, Maharashtra, Gujarat, Jammu \& Kashmir, Karnataka, Jharkhand, Odisha, Madhya Pradesh, and Telangana contribute $24 \%$ of the degraded area in the country. Water erosion is the highest contributor (10.98\% in 2011-13 and $10.83 \%$ in 2003-05), followed by vegetation degradation ( $8.91 \%$ in $2011-13$ and $8.60 \%$ in 2003-05) and wind erosion (5.55 \% in 2011- 13 and $5.58 \%$ in 2003-05). The area under desertification (arid, semi-arid, and dry sub-humid regions of the country) during 2011-13 was 82.64 Mha, whereas during 2003-05, it was 81.48 Mha. Thus, there is a cumulative increase of 1.16 Mha area under desertification. The most significant processes of desertification in the arid region have been observed to be wind erosion and, in semi-arid and dry sub-humid regions, vegetation degradation and water erosion (GoI, 2016). These estimates are much higher than the earlier assessment from the National Remote Sensing Agency (NRSA), which estimated the extent of land degradation in India at about 35.5 million hectares in 1999 (Reddy, 2003). This is mainly due to changes in definitions as well as the inclusion of forest degradation (vegetation degradation).

The pace of degradation has gone up during the post-green revolution period due to the intensive use of chemical inputs (Table 1). India has a long history of soil conservation interventions and programmes. From the early $20^{\text {th }}$ century onwards, though, soil conservation was not among the policy priorities until the 1980s. As the extent of degradation increased over the years, soil conservation gained policy attention (refer to appendix table on Policies). However, a more focused approach to soil management has been adopted only after 2014-15. This coincided with the declaration of the international year of soils by the UN. Soil health is a holistic concept that includes the chemical, physical, and biological health of the soil (Figure 1). In line with the UN resolution, the ministry of agriculture introduced the Soil Health Card (SHC) scheme on December 5, 2015. The scheme is an improvement on the earlier National Project on Management of Soil Health and Fertility that was launched during 2008-09.

Fig1: Measure of Soil Health

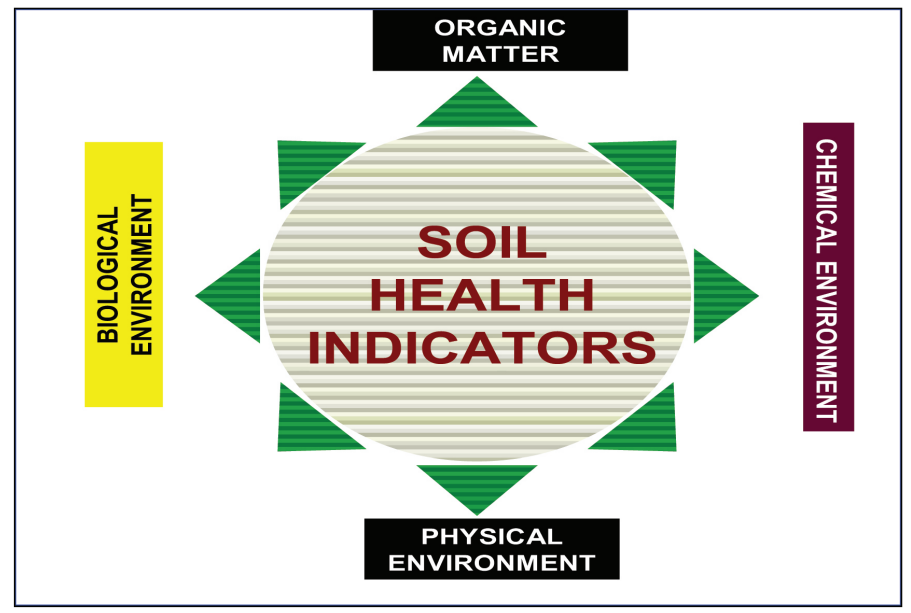

${ }^{1}$ The new estimates refer to process of degradation, which includes heavy degradation and degraded lands, while the earlier estimates included only degraded lands. Besides, the earlier estimates provided forest degradation assessment separates. If these definitional differences are taken into account, the estimates become comparable. 
Table 1: Consumption of Fertilisers in million tonnes in India

\begin{tabular}{|llllllll|}
\hline & \multicolumn{3}{c}{ Million tonnes } & \multicolumn{5}{c|}{ NPK ratio } \\
\hline Year & $\mathbf{N}$ & $\mathbf{P}$ & $\mathbf{K}$ & Total & $\mathbf{N}$ & $\mathbf{P}$ & $\mathbf{K}$ \\
\hline 1956 & 0.1 & 0.0 & 0.0 & 0.1 & 10.4 & 1.3 & 1 \\
\hline 1981 & 3.7 & 1.2 & 0.6 & 5.5 & 5.9 & 1.9 & 1 \\
\hline 1991 & 8.0 & 3.2 & 1.3 & 12.5 & 6.0 & 2.4 & 1 \\
\hline 2001 & 10.9 & 4.2 & 1.6 & 16.7 & 7.0 & 2.7 & \\
\hline 2011 & 16.6 & 8.0 & 3.5 & 28.1 & 4.7 & 2.3 & 1 \\
\hline 2015 & 16.9 & 6.1 & 2.5 & 25.6 & 6.7 & 2.4 & 1 \\
\hline
\end{tabular}

India is consuming about 25.6 million tonnes of fertilisers, mostly Nitrogen (17 million tonnes) followed by Phosphorous ( 6 million tonnes) and Potassium ( 2.5 million tonnes). The current NPK ratio is 6.7:2.4:1, which is highly skewed towards Nitrogen as against the ideal ratio of $4: 2: 1$ (Table 1). There are wide variations across the states in terms of fertiliser use per acre and NPK ratios (Figure 2). India is spending about Rs. 1 lakh crore on fertiliser subsidy. It is estimated that the subsidy amount is about Rs. 6,500/ha of the net cropped area and about Rs. 7,000/farmer, resulting in excessive use of fertilisers, especially Nitrogen, at the cost of micro nutrients and manure (Figure 3). As a result of the excessive and unbalanced use of fertilisers, the amount of food grain produced per $\mathrm{kg}$ of fertiliser applied declined from $13 \mathrm{~kg}$ in the $1970 \mathrm{~s}$ to just $4 \mathrm{~kg}$ by 2010 . In order to promote balanced use of fertilisers, the Government of India introduced the Soil Health Card Scheme across India.

Fig. 2: State-wise Fertiliser use (kg/ha) and N:K Ratio

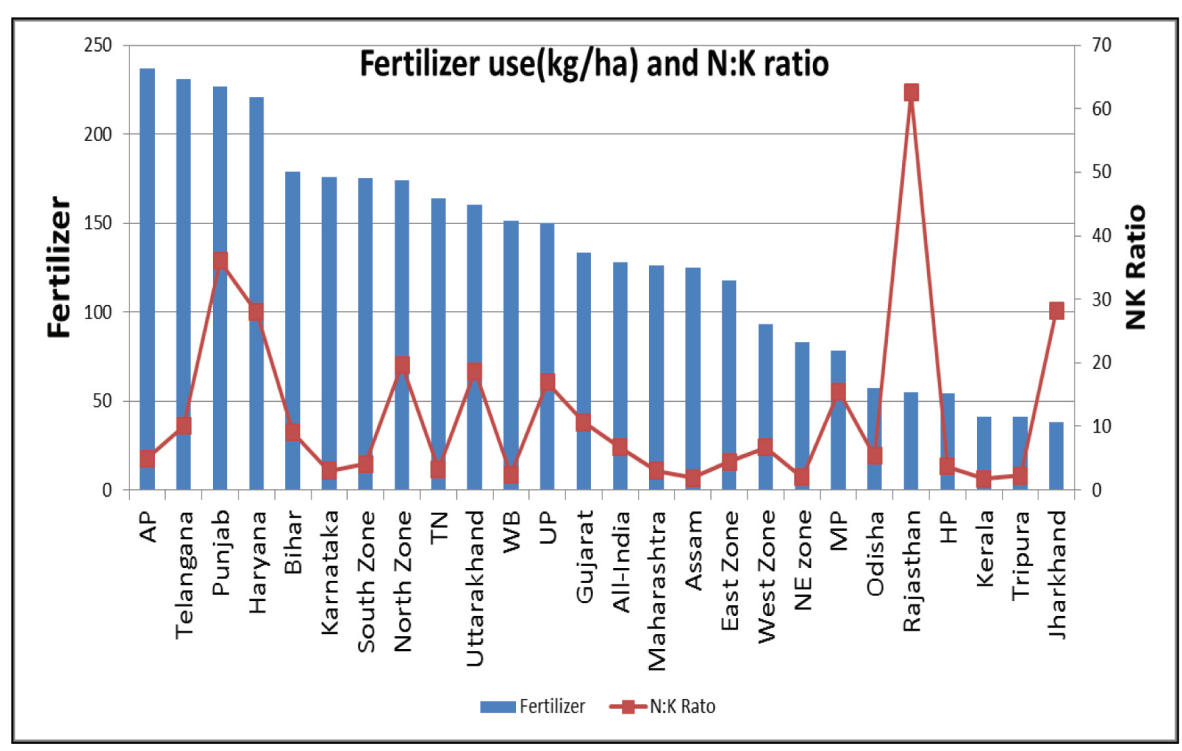

The SHC scheme was approved for implementation for the remaining period of the $12^{\text {th }}$ plan. The scheme aims to provide SHC to all farmers in the country at a regular interval of two years in order to enable the farmers to apply recommended dosages of nutrients to realise improved and sustainable soil health and fertility status and reap higher profits. The scheme has the following objectives:
a) To improve soil quality and profitability to farmers
b) To generate employment for the rural youth
c) To improve timelines in the analysis of soil samples.
d) To introduce a single window approach from collection to the issue of SHC minimising delays and maximising convenience for farmers.
e) To provide online delivery of SHC to farmers using the soil health card portal.
f) To provide soil testing facilities to farmers at their doorstep. 
Fig 3: Progressive expansion in the occurrence of nutrient deficiency

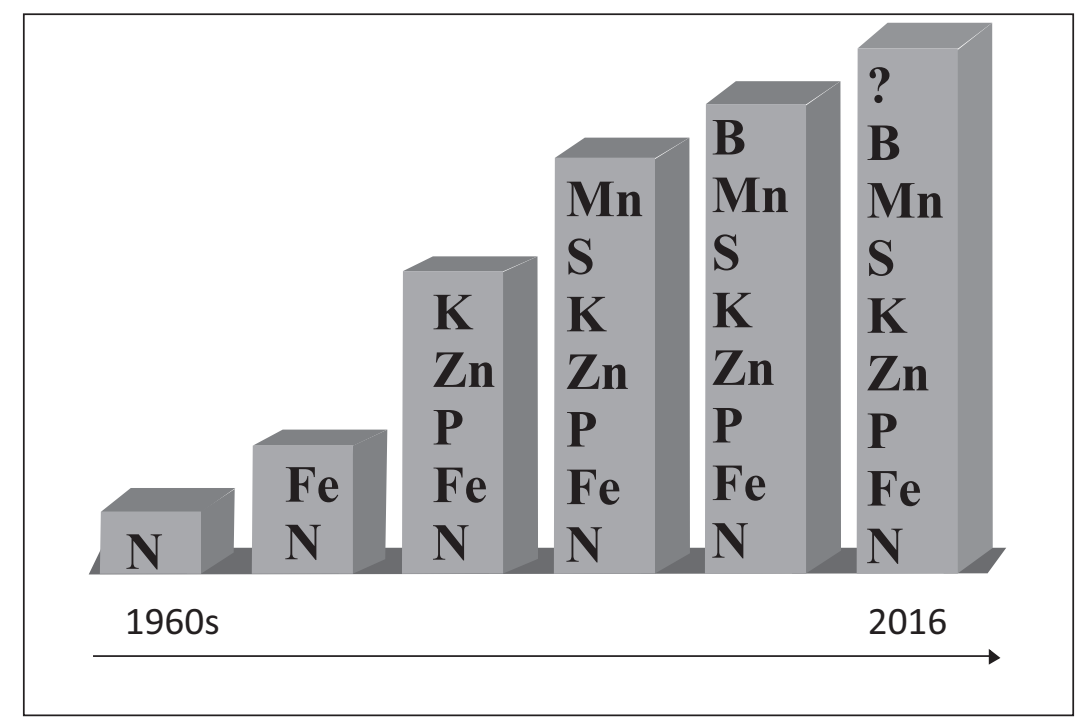

Under the SHC scheme, the cropped area was divided into grids of 10 ha for rainfed and 2.5 ha for irrigated and only one soil sample from each grid was taken. The test results will be distributed among all the farmers whose area was falling under the grid. Based on the grid system, the total 14.1 crore hectares of the net cropped area requires a total of 3.46 crore grid samples (with $52 \%$ of the area under rainfed [ 7.3 crore ha] with 73 lakh grid samples and 48\% area under irrigated [ 6.8 crore ha] with 2.72 crore grid samples). The target is to cover 1.73 crore grid samples per year. This comes to an average of 25,000 grid samples per district/year and 29 grid samples per village/year. With this, all 10.39 crore farmers will be covered in two years. Every year, 5.2 crore farmers need to be covered.

Under cycle 1,2.54 crore samples were collected, 2.36 crore samples tested, 9.62 crore soil health cards printed, but only 9.33 crore SHCs distributed. This indicates that $100 \%$ target was archived in sample collection, $93 \%$ of the target was achieved in soil testing, but only $80 \%$ of the target was achieved in SHC printing. 97\% of the SHCs printed were distributed among the farmers as on September 24, 2017. However, the progress is highly skewed. Some states, such as Karnataka, Tamil Nadu, Chhattisgarh, Uttar Pradesh, Maharashtra, Telangana, and Andhra Pradesh, were better performers compared to other states. 


\section{Chapter -II}

\section{Soil Health in India: Review of Experience}

Though there are a number of studies on the ill effects of poor soil quality across different states of India, they mostly focus on micro situations. There are no all-India studies on the impact of improved soil health. Of late, some studies have assessed the impact of soil health management programmes in Karnataka, Andhra Pradesh, Bihar, Gujarat, etc., where state governments have initiated the programmes viz. Bhoochetana in Karnataka and Krishi Mahostav in Gujarat. Here, the experiences of these initiatives are reviewed briefly (details of the studies are presented in appendix table 2).

Studies have clearly shown that farmers do adopt soil management strategies (Reddy, 2011). Most of these practices are based on their rich experience and vast knowledge of location-specific conditions. Combination of chemical fertilisers and FYM was a predominant practice, along with mixed cropping and legume cultivation. This shows that farmers understand the role of FYM and other organic manure. The analysis also showed a positive sign of the emerging organic markets. The availability of FYM is limited; promotion of fertiliser use (advertisements) and huge subsidy force farmers to use more chemical fertilisers. Farmers have indicated that recommendations provided by scientists without proper soil testing do not hold well for the conditions they are working in.

A study of impact assessment of SHC in three districts of Bihar observed that there is a large gap between recommended and actual application of fertilisers, especially in the case of urea. Despite the recommendations provided by SHC, farmers fail to adopt them (Fishman, et al., 2016). The main reasons for this include: i) farmers didn't understand the contents of the SHC; ii) farmers didn't find the soil analysis and fertiliser recommendations to be reliable or compelling; iii) other factors such as cost, liquidity, or timely availability of specific fertilisers were an added constraint.

On the other hand, studies have shown that when awareness programmes are followed up with supporting programmes such as inputs etc., soil improvements and increased crop yields are conspicuous. For instance, the Bhoochetana programme in Karnataka introduced direct benefit transfer in fertiliser subsidy to increase efficiency and strengthen fertiliser supply chain along integrated nutrient management with emphasis on organic fertilisers. Under this programme, the Karnataka government supplied micro nutrients at 50\% subsidy. The study estimated that total benefits with soil health mapping and soil-test-based fertiliser recommendations along with improved practices would be Rs.4.33 lakh crore, against the estimated cost of Rs 0.254 lakh crore (ICRISAT research report IDC-6). The benefit-cost ratio would be 17:1. Besides economic benefits, there is employment generation and several environmental benefits, including enhancing the sustainability of Indian agriculture, which will be additional benefits.

Similarly, surface drainage technology for saline land reclamation was observed to be technically viable, economically feasible, and socially acceptable. The study by Raju, et al., (2015) clearly showed that land use was intensified, cropping patterns changed in favour of more remunerative crops, and crop yields increased with the use of soil health cards. There was a significant reduction in the maximum and minimum salinity. The mean yield of all crops grown significantly increased to the extent of $186 \%$. Increase in net income was largely related to the increase in crop yield due to soil improvements. 
A significant increase in net income from off-season crops was also observed. The benefit-cost ratio was more than one, and the value of land increased as well (Raju, et.al., 2015).

In a study on on-farm trails in eight districts of Andhra Pradesh, it was found that balanced nutrient treatment in the widespread multi-nutrient (including micro nutrients) deficient soils has resulted in significantly higher yields. Balanced nutrition while increasing crop yields maintained plant nutrient composition. Post-harvest soil testing in the Nalgonda district showed higher contents of soil organic carbon and available nutrients such as $\mathrm{P}, \mathrm{S}, \mathrm{B}$, and $\mathrm{Zn}$ in plots with balanced nutrition treatment. In the absence of balanced nutrition, farmers were losing $8 \%$ to $102 \%$ of current yields in season 1 and $15 \%$ to $24 \%$ in each of the succeeding three to four seasons (Chander, et al., 2014)

\subsection{Soil Health in India}

According to the report "Degraded and Waste Lands of India" by the Indian Council for Agricultural Research (ICAR) and the National Academy for Agricultural Sciences, of the 141 million hectares of total geographical area, about 328.2 million hectares is under cultivation. Of this, about 100 million hectares-or 70\%-is heading down a path where it will be incapable of supporting farming. Farmers are making the soil work more, growing two or more crops a year instead of one without proper soil health management. This unplanned intensification is exacerbating nutrient shortages and changing soils' chemical composition. Levels of organic carbon in soil are dropping across the country, making soils more vulnerable to erosion and possibly resulting in the number of earthworms falling. Not only do these excesses and imbalances reduce the productivity and life of soils, they are now resulting in poor nutritional value of our food. If the soils are deficient in some nutrients, so are the food crops grown on them. Pharma companies have consequently started adding Zinc, Copper, Selenium, Chromium, etc. to fortify their vitamin tablets.

\subsection{Soil Nutritional Status}

Indian Institute of Soil Science, (IISS) data shows that large parts of India are deficient in two or more critical nutrients. Regions such as the Indo-Gangetic plains-Punjab, Haryana, Uttar Pradesh, and Bihar-which produce nearly $50 \%$ of our grains and feed about $40 \%$ of our population are seeing multiple nutrient deficiencies. The reason is the imbalanced use of organic and inorganic inputs. In the past, farmers used to plough the stalks left standing on the field after the harvest, cow dung, etc. back into the soil. This ensured that nutrients taken out of the soil were replenished. The green revolution that started in the 60 s changed all that. High-yielding crop varieties need more water and nutrients, spanning macro nutrients such as Nitrogen and Phosphorus to micro nutrients such as Copper and Boron. However, due to imbalanced fertiliser use, hardly any of these nutrient cycles are being completed. Farmers today use more of Urea (Nitrogen), some Potassium and Phosphorus, but not much else. Further, they choose fertilisers more by affordability and availability than what the soils need. Apart from retarding growth in yields, this unbalanced use has also damaged soils. Too much urea, for instance, turns soils acidic. The ICAR report estimates that 6.98 million hectares, or 2\% of India's total geographical area, have acidic soils. These are mostly in North-East India, south Chhattisgarh, and Kerala. Another 6.7 million hectares are salt-affected. In the absence of historical data on nutrients, the degree of decline cannot be ascertained. These soils are increasingly incapable of supporting agriculture. 


\subsection{Soil Organic Carbon}

Soils are changing from fine to hard. In healthy soils, crop residues are transformed by earthworms and other soil fauna into soft and spongy organic matter called humus (or organic carbon). This soaks up water, creates an environment where soil fauna such as earthworms thrive, and binds the soil's three constituents: sand, silt, and clay. Without humus, the soils compress and harden. Farmers, in a hurry to plant the next crop, burn their fields to clear stalks left standing after the harvest. Cow dung is scarcer. That's partly because with mechanisation, fewer households keep bullocks. The decline of grazing grounds has meant only households large enough to afford fodder can keep milch animals. The recommended amount of farmyard manure is 5-10 tonnes per hectare, whereas farmers add anywhere between zero to five tons. Poorer farmers sell manure instead of ploughing it into their fields. Or, they use dried dung as fuel. The outcomes are predictable. IISS estimated that humus depletion in the top 0$15 \mathrm{~cm}$ is nearly $50 \%$, although it can occasionally be as high as $60-70 \%$ in some soil types. There is $10-$ $20 \%$ loss in the $15-100 \mathrm{~cm}$ below that top layer. As humus falls, properties of the soil change. For example, its ability to absorb water reduces, resulting in erosion. The ICAR report estimates that a total of $126 \mathrm{M}$ ha is suffering from various degrees of water erosion. Of this, 0.68 million hectares are seeing severe, very severe, and extremely severe erosion. Another 0.2 million hectares is seeing "moderately severe" erosion. The report estimates that very severe and severe wind erosion occurs in $16 \%$ of India's total geographical area. Both these processes contribute to desertification-soil turning into a desert. About 81 million hectares, or $25 \%$ of it, is experiencing desertification, says a 2009 ISRO paper titled 'Desertification/land degradation status mapping of India'. Anecdotal information suggests that the number of earthworms and other soil insects is falling.

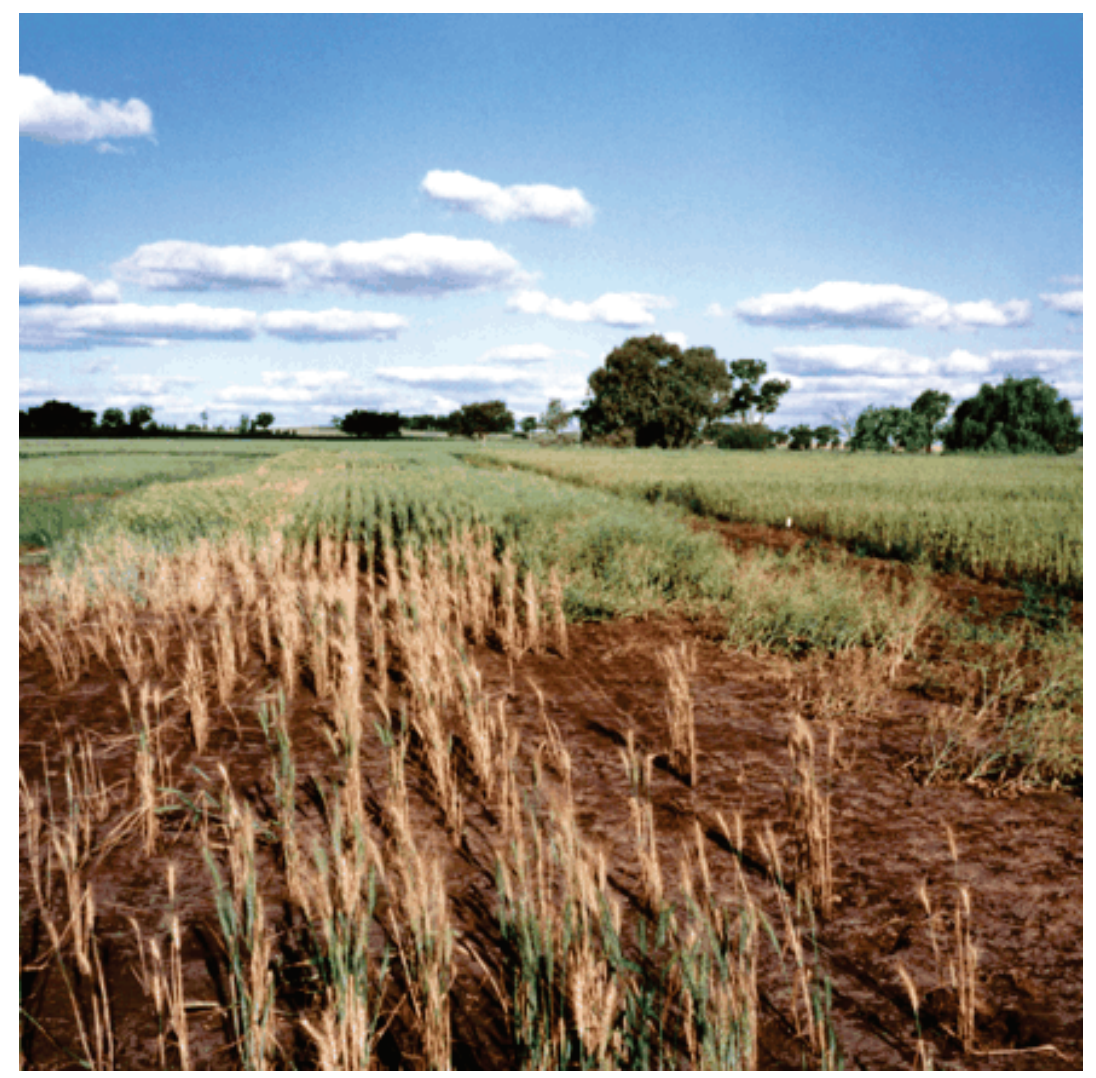

Fig. 4: Fields effected by alkalinity 


\subsection{Soil Health Card to Improve Soil Health}

The Soil Health Card programme is trying to address these problems. However, it is a crisis that we are just starting to deal with. One of the few exceptions is the government's switch to Nutrient-based Subsidy. As a response to growing micro nutrient shortages, it falls short, partly because the price signals it sends out about the nutrients to use are national while the shortages are local; partly because the government has decontrolled prices of $\mathrm{P}$ and $\mathrm{K}$ while holding on to prices of $\mathrm{N}$. As a result, every time $\mathrm{P}$ and $\mathrm{K}$ prices soar, farmers dump more urea than other fertilisers; and partly because it doesn't extend the subsidy to organic manure or all 20 micronutrients: it only covers Boron and Zinc. We do not have pan-India authentic baseline data about soil nutrient concentrations. The Indian Institute of Soil Science (IISS) data, as shown in (Map 1, Map 2, Map 3 and Map 4), was derived from samples collected by soil-testing labs. The quantum of deficiency in these maps has been calculated by gauging the minimum concentration of a nutrient required (for that soil type) for above normal yields. However, macro nutrient deficiency has been mapped for only 18 odd states.

In the case of micro nutrients, we know their concentration in even fewer states with a very limited sample. There is no authentic data on pan-India soil microbial population and activity. Tamil Nadu, Gujarat, and Punjab are better in this regard than other states. India has 140 million farmers, but our labs cannot process more than 8 million soil samples in a year. It will take us 15 years, at this rate, to tell every farmer what their soil needs. The larger question is about the soils' physical condition: can they support the hydrological cycle? And for that, you need humus and soil biota. Earthworm populations, organic carbon levels, and yields are the highest when a combination of balanced fertilisation and farmyard manure is used. However, India doesn't have enough cow dung. Organic waste can be used instead of cow dung, but we need to figure out better ways to segregate organic and inorganic waste and get it across to fields. Various state governments are encouraging composting pits where agricultural and household wastes can decompose into manure that is then ploughed back into the soil.

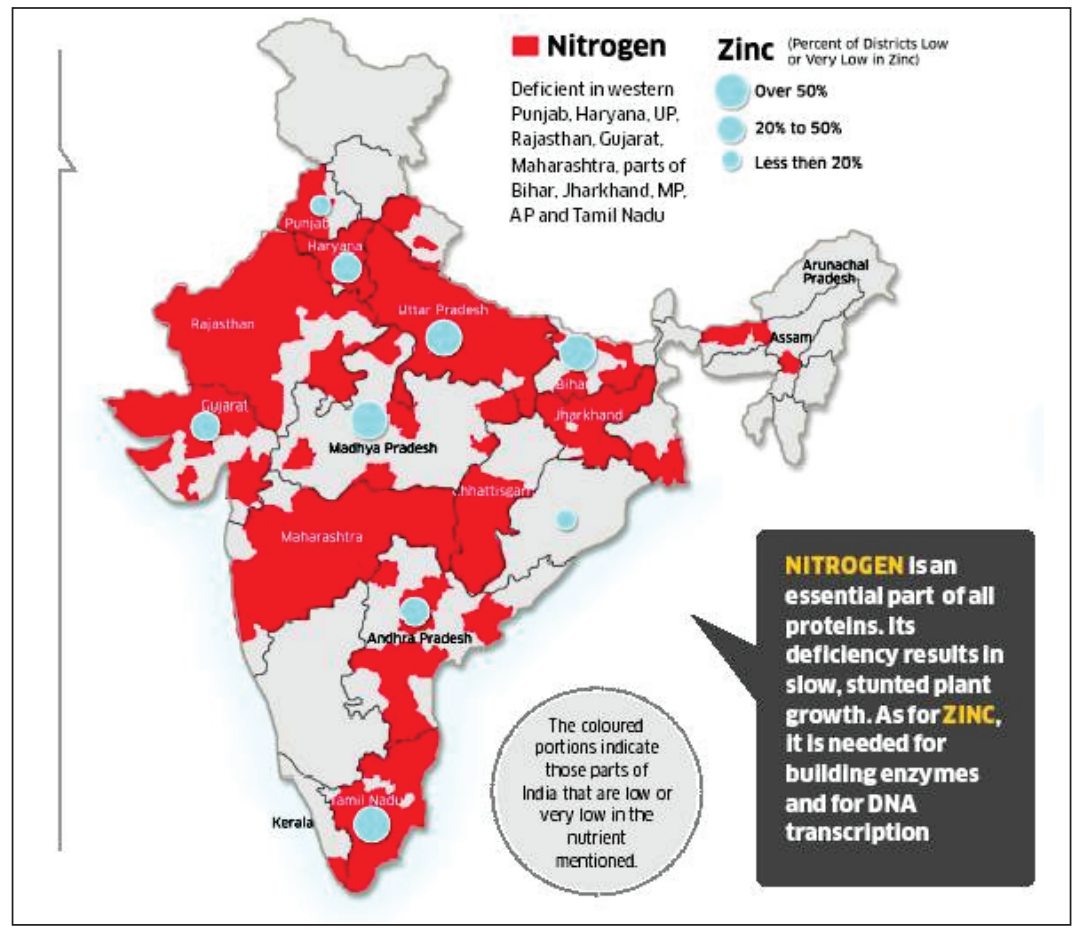

Map 1: Status of Nitrogen and Zinc availability in Indian soil (source: Economic Times) 


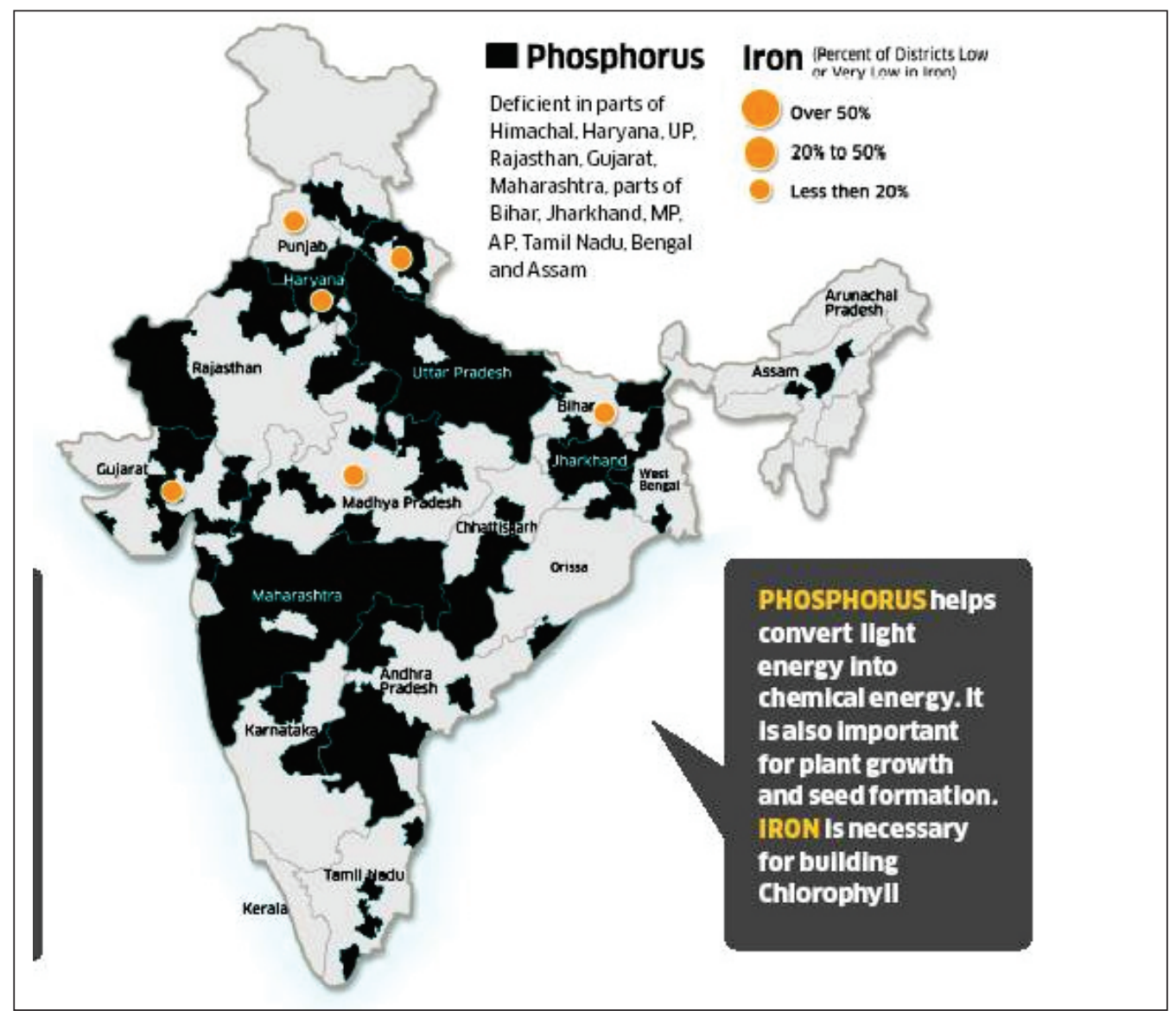

Map 2: Status of Phosphorus and Iron availability in Indian soil

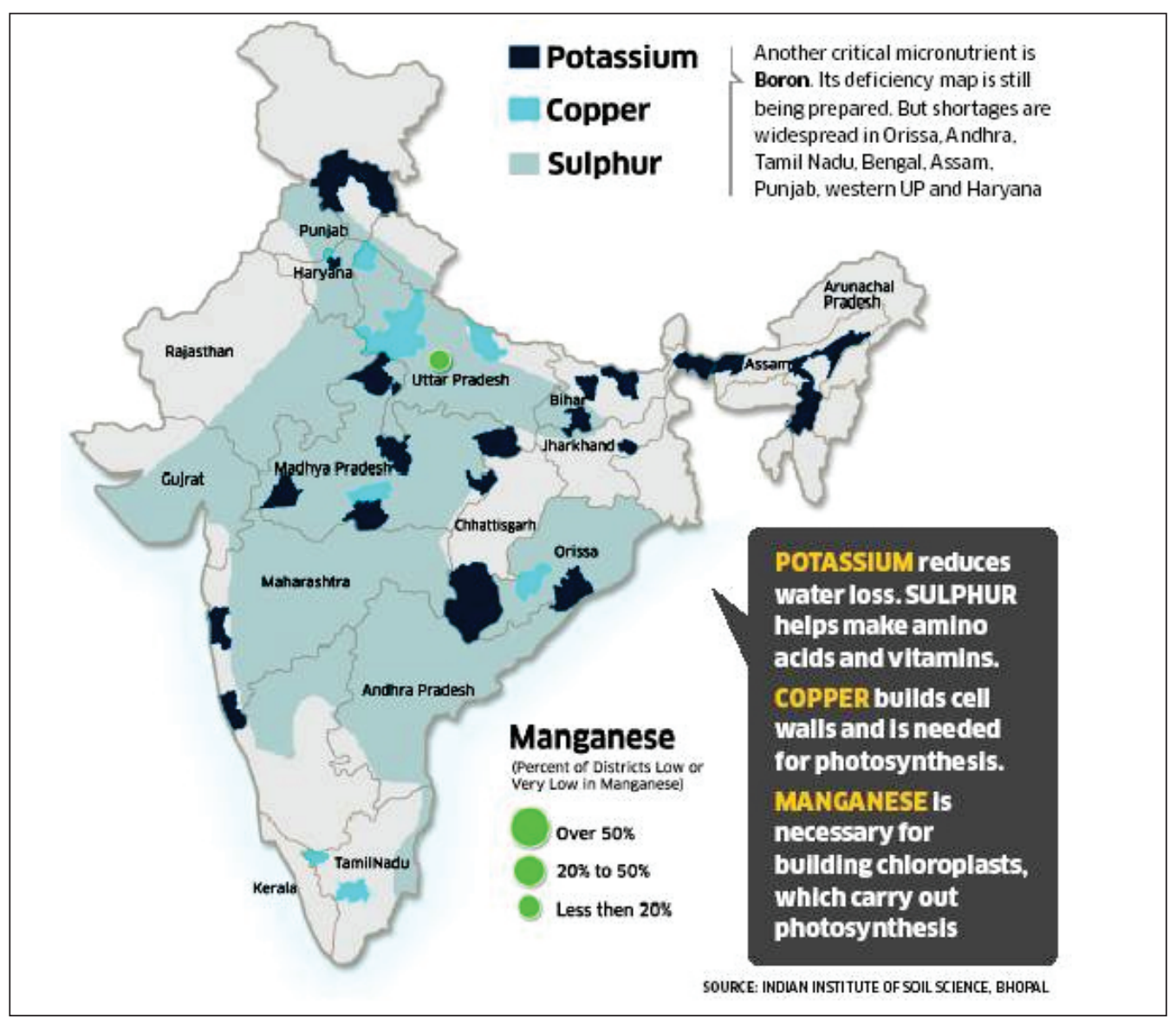

Map 3: Status of Potassium, Copper and Manganese availability in Indian soil 


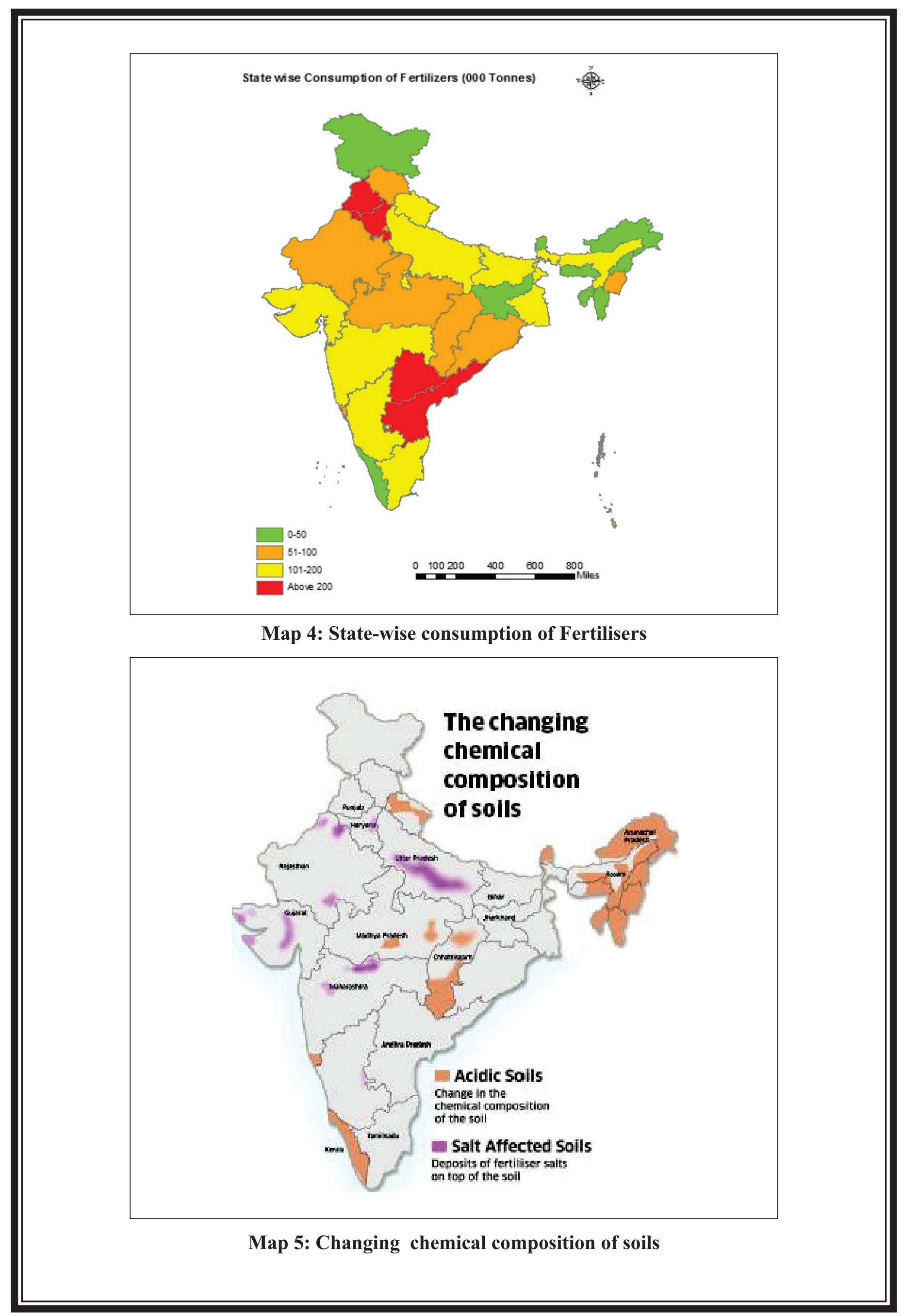




\section{Chapter - III}

\section{Policy Interventions over the Years: International and National}

Though soil management practices and policies are as old as agriculture, formal land management policies at the international level were initiated in the early 1980s with the first World Soil Charter (WSC) adopted by the FAO (Food and Agriculture Organisation) member countries in 1982 under the global soil partnership. This was followed up with a number of international policy initiatives such as the Intergovernmental Panel on Climate Change (IPCC) in 1988. Soil management received a flip with UNCCD (United Nations Convention to Combat Desertification), focusing on drought mitigation and combat desertification. This was followed by the Rio conference, which provided 27 principles to guide countries towards sustainable development. Following this, a number of conventions and protocols were initiated to help soil management at the global level. The important ones among them include:

\subsection{Global policies}

a. 1997: The Kyoto Protocol is an international treaty that extends the 1992 United Nations Framework Convention on Climate Change (UNFCCC), which commits state parties to reduce greenhouse gas emissions based on the scientific consensus that (a) global warming is occurring and (b) it is extremely likely that human-made _CO2emissions have predominantly caused it.

b. 2000: MDG's - Soil management and prevention of desertification. Implementation of soil erosion control (by wind and water) by planting windbreaks and cover crops; improvements in soil fertility with agro-forestry systems, cover crops, and conservation of ground and surface water.

c. 2005: The Millennium Ecosystem Assessment looked at the consequences of ecosystem change for human well-being. From 2001 to 2005, the MEA involved the work of more than 1,360 experts worldwide. Their findings provide a state-of-the-art scientific appraisal of the condition and trends in the world's ecosystems and the services they provide as well as the scientific basis for action to conserve and use them sustainability.

d. 2008: This UNCCD policy brief "A Sustainable Development Goal for Rio+20: Zero Net Land Degradation" provides a snapshot of the world's land, explains the causes and impacts of land degradation, and suggests pathways to land-degradation neutrality. The brief reveals that sustainable land use is a prerequisite for ensuring future water, food, and energy security. Given the increasing pressure on land from agriculture, forestry, pasture, energy production, and urbanisation, urgent action is needed to halt land degradation.

e. 2011: The Global Soil Partnership for Food Security and Climate Change Mitigation and Adaptation (GSP) brings together international, regional, and national organisations that are working in the area of soil protection and sustainable management. Launched by the Food and Agriculture Organisation of the United Nations in Rome on September 7, 2011, the partnership 
aims to implement the provisions of the 1982 World Soil Charter and raise awareness and motivate action by decision-makers on the importance of soils for food security and climate change adaptation and mitigation.

f. 2012: Sustainable Development Goal 15 of the 2030 Agenda aims to "protect, restore, and promote sustainable use of terrestrial ecosystems, sustainable forest management, combat desertification and halt and reverse land degradation and halt biodiversity loss".

g. 2013: The Intergovernmental Technical Panel on Soils (ITPS) was established in the first Plenary Assembly of the Global Soil Partnership held at FAO Headquarters on June 11 and 12, 2013. The ITPS is composed of 27 top soil experts representing all the regions of the world. The main function of the ITPS is to provide scientific and technical advice and guidance on global soil issues to the Global Soil Partnership primarily and to specific requests submitted by global or regional institutions. The ITPS will advocate for addressing sustainable soil management in the different sustainable development agendas.

h. 2015: The International Year of Soils, 2015 (IYS 2015), was declared by the 68th session of the United Nations General Assembly on December 20th, 2013, after recognising December 5 as World Soil Day. The purpose of the IYS is to raise awareness worldwide about the importance of soils for food security, agriculture, as well as in mitigation of climate change, poverty alleviation, and sustainable development.

\subsection{National Policies}

In India, formal soil and water interventions were under way since 1900 under the British rule. Post independence, soil management has become part of five year plans from the first plan onwards (refer to the appendix table). A number of initiatives have been taken up at the national level over the years. Apart from the soil reclamation programmes during the 1970s and 80s and soil and water conservation programmes going on over the years (mainly watershed development programmes), no specific soil management programme was initiated at the national level. For the first time, during the $11^{\text {th }}$ plan, National Mission for Sustainable Agriculture (NMSA) was introduced as a part of the National Action Plan on Climate Change (NAPCC). The National Project on Management of Soil Health and Fertility and the Rainfed Areas Development Programme (RADP) was also introduced. It recommended conservation agriculture, integrated nutrient management, carbon sequestration, erosion control, saline and alkaline soils management, legislation for soil protection, development of remote sensing and GPS (Global Positioning System) based on Decision Support System (DSS) and amelioration of polluted soil to rejuvenate deteriorated soils. This was followed up in the 12th plan by introducing a new scheme, 'National Project on Management of Soil Health \& Fertility' (NPMSH\&F). Under this scheme, soil health cards were introduced along with strengthening of soil testing labs and expanding their testing capacity. Furthermore, the Nutrient-Based Subsidy (NBS) system was introduced. In the recent years, some states, such as Karnataka, Gujarat, etc., have introduced soil management programmes, such as Bhoochetana and Krishi Mahotsav programmes. These programmes have provided insights and learnings related to the central schemes. 
Table 2: Soil Quality and Quantity Indicators

\begin{tabular}{|c|c|c|c|}
\hline Indicator & Poor & Medium & Good \\
\hline Earthworms & $\begin{array}{l}\text { 0-1 worms in shovelful } \\
\text { of top foot of soil. No } \\
\text { casts or holes }\end{array}$ & $\begin{array}{l}2-10 \text { in shovelful } \\
\text { few casts, kholes or } \\
\text { worms }\end{array}$ & $\begin{array}{l}10+\text { in top foot of soil. Lots } \\
\text { of casts and holes in tiled } \\
\text { clods. Birds behind tillage }\end{array}$ \\
\hline $\begin{array}{l}\text { Organic } \\
\text { matter colour }\end{array}$ & $\begin{array}{l}\text { Top soil colour similar } \\
\text { to sub-soil colour }\end{array}$ & $\begin{array}{l}\text { Surface colour } \\
\text { closer to sub-soil } \\
\text { colour }\end{array}$ & $\begin{array}{l}\text { Top soil clearly defined, } \\
\text { darker than sub-soil }\end{array}$ \\
\hline Roots/residue & $\begin{array}{l}\text { No visible residue or } \\
\text { roots }\end{array}$ & $\begin{array}{l}\text { Some residue, few } \\
\text { roots }\end{array}$ & Visible residue and roots \\
\hline $\begin{array}{l}\text { Surface } \\
\text { compaction }\end{array}$ & $\begin{array}{l}\text { Wire breaks or bends } \\
\text { when inserting } \\
\text { surveyors flag }\end{array}$ & $\begin{array}{l}\text { Have to push hard, } \\
\text { need fist to push } \\
\text { flag in }\end{array}$ & $\begin{array}{l}\text { Flag goes in easily with } \\
\text { fingers with twice the depth } \\
\text { of the plow layer }\end{array}$ \\
\hline $\begin{array}{l}\text { Soil tilth } \\
\text { mellowness } \\
\text { friability }\end{array}$ & $\begin{array}{l}\text { Looks dead. Like brick } \\
\text { or concrete cloddy. } \\
\text { Either blows apart or } \\
\text { hard to pull drill } \\
\text { through. }\end{array}$ & $\begin{array}{l}\text { Somewhat cloddy. } \\
\text { Balls up, rough } \\
\text { pulling seedbed. }\end{array}$ & $\begin{array}{l}\text { Soil crumbles well, can slice } \\
\text { through, like cutting butter. } \\
\text { Spongy when you walk on it. }\end{array}$ \\
\hline Erosion & $\begin{array}{l}\text { Large gullies over two } \\
\text { inches deep joined to } \\
\text { others, thin or no top } \\
\text { soil, rapid run-off the } \\
\text { colour of the soil }\end{array}$ & $\begin{array}{l}\text { Few rills or gullies, } \\
\text { gullies up to two } \\
\text { inches deep. Some } \\
\text { swift runoff, } \\
\text { coloured water }\end{array}$ & $\begin{array}{l}\text { No gullies or rills. Clear or } \\
\text { no runoff. }\end{array}$ \\
\hline $\begin{array}{l}\text { Water holding } \\
\text { capacity }\end{array}$ & $\begin{array}{l}\text { Plant stress two days } \\
\text { after a good rain }\end{array}$ & $\begin{array}{l}\text { Water stress after a } \\
\text { week }\end{array}$ & $\begin{array}{l}\text { Holds water for a long period } \\
\text { of time without puddling. }\end{array}$ \\
\hline $\begin{array}{l}\text { Drainage } \\
\text { infiltration }\end{array}$ & $\begin{array}{l}\text { Water lies for a long } \\
\text { time and evaporates } \\
\text { more than drains, } \\
\text { always very wet } \\
\text { aground }\end{array}$ & $\begin{array}{l}\text { Water lies for a } \\
\text { short period of the } \\
\text { time and eventually } \\
\text { drains. }\end{array}$ & $\begin{array}{l}\text { No ponding runoff water; } \\
\text { moves through soil steadily. } \\
\text { Soil not too wet, not too dry. }\end{array}$ \\
\hline $\begin{array}{l}\text { Crop } \\
\text { condition }\end{array}$ & $\begin{array}{l}\text { Problem growing } \\
\text { throughout season, } \\
\text { poor growth, yellow or } \\
\text { purple colour }\end{array}$ & $\begin{array}{l}\text { Fair growth, } \\
\text { medium green } \\
\text { colour }\end{array}$ & $\begin{array}{l}\text { Normal, healthy dark green } \\
\text { colour, excellent growth all } \\
\text { seasons across fields }\end{array}$ \\
\hline $\begin{array}{l}\text { pH nutrient } \\
\text { holding } \\
\text { capacity }\end{array}$ & $\begin{array}{l}\text { Hard to correct for } \\
\text { desired crop } \\
\text { Soil test values } \\
\text { dropping with more } \\
\text { fertiliser applied than } \\
\text { crops use }\end{array}$ & $\begin{array}{l}\text { Little or slow } \\
\text { change }\end{array}$ & $\begin{array}{l}\text { Proper } \mathrm{pH} \text { for crop } \\
\text { Fair growth, spots in field } \\
\text { different, medium green } \\
\text { colour. }\end{array}$ \\
\hline
\end{tabular}




\section{Chapter IV \\ Objectives and Methodology}

\subsection{Objectives:}

As the SHC scheme has completed more than 2 years of implementation, the ministry has initiated a nationwide impact assessment with the following objectives:

To examine the design of the SHM/ SHC scheme in terms of planning, implementation (role of state/ JDA/ADA/AO), inputs (staff, financial and other resources), activities (training, lab established and strengthened), outputs (SHCs printed and distributed to farmers).

To assess the modalities of delivery of the SHM / SHC scheme in terms of procurement, sample collection, testing, SHC printing, and disbursal.

To assess the level of utilisation of SHCs by the farmers across farm size classes in irrigated and rainfed situations.

To assess the impacts of SHC scheme on judicious use of fertilisers, biofertilisers, organic fertilisers, soil health, cropping choice, cost reduction, farm profitability, and sustainability.

To recommend improvement in the overall design of the programme.

\subsection{Methodology}

Both qualitative and quantitative approaches were used to assess the impact of the Soil Health Card Scheme. Qualitative information in the form of stakeholder interviews across the study states, expert opinion gathering at the national and state levels through workshops, and interactions with the progressive farmers were carried out. At the quantitative level, both secondary and primary data was collected at the national, state, and farmer levels. Secondary data mainly pertains to financial and physical achievements of the SHC scheme over the years, infrastructure availability, number and capacity of Soil Testing Laboratories, and utilisation capacity were collected and analysed.

A systematic sample has been drawn for the impact assessment at the farmer level. Care was taken to represent the whole country and different agro-climatic conditions. The sampling details are presented as follows.

\subsubsection{Selection of States, Districts, and Blocks}

For the secondary data, all the states were covered to understand the number of SHCs issued and farmers covered, financial and physical progress of the inputs, activities and outcomes of the SHC scheme. For primary data collection, all major states (25 major states) were divided into five zones for drawing the sample. From each zone, 2-4 states were selected, and a total of 16 states were selected for primary data collection. At the next level, two districts from each state (three districts in case of large states and one district in case of small states) were selected, i.e, a total of 29 districts. From each district, two blocks were selected randomly, i.e., a total of 65 blocks. From each block, two to three villages were selected randomly, i.e., a total of 199 villages. From each village, 16 households were selected for collecting detailed information with the help of a structured questionnaire (refer to appendix). Overall, 3,184 households were covered at the national level (Table 2).

Due care was taken to represent a few farmers who received SHC at least a year before the survey date in order to understand the impact. Hence, the sample size varies a little according to the availability of the oldest adopters in villages. Due care was also taken to cover small and marginal farmers, SC/ST farmers, educated youth, and beneficiaries under demonstrations (Table 3). The impact of SHC was assessed using the before and after methodology and also using with and without wherever possible. 
We have also classified respondents based on the period of holding SHC, oldest (received SHC more than 1 year ago), old (6 months ago), new (4 months ago), and recent (less than 4 months) to assess the impacts over the period.

All the states were grouped into zones based on standard classification. Northern Zone comprised Chandigarh, Delhi, Haryana, Himachal Pradesh, Jammu and Kashmir, Punjab, and Rajasthan; NorthEastern Zone comprised Assam, Arunachal Pradesh, Manipur, Meghalaya, Mizoram, Nagaland, Sikkim, and Tripura; Central Zone comprised the states of Chhattisgarh, Madhya Pradesh, Uttarakhand, and Uttar Pradesh; Eastern Zone comprised Bihar, Jharkhand, Odisha, and West Bengal; Western Zone comprised Dadra and Nagar Haveli, Daman and Diu, Goa, Gujarat, and Maharashtra; Southern Zone comprised Andhra Pradesh, Karnataka, Kerala, Lakshadweep, Puducherry, Tamil Nadu, and Telangana.

Table 3: Details of the sampling framework

\begin{tabular}{|l|l|l|l|l|c|}
\hline Zone & States & Districts & Blocks & Villages & $\begin{array}{c}\text { Total } \\
\text { Sample Farmers }\end{array}$ \\
\hline Central & 2 & 3 & 6 & 20 & 320 \\
\hline East & 2 & 3 & 7 & 15 & 240 \\
\hline North-East & 4 & 4 & 10 & 28 & 448 \\
\hline North & 3 & 8 & 11 & 54 & 864 \\
\hline South & 3 & 7 & 24 & 50 & 800 \\
\hline West & 2 & 4 & 7 & 32 & 512 \\
\hline Total & 16 & 29 & 65 & 199 & 3184 \\
\hline
\end{tabular}

For primary data collection, the following states were covered under each zone:

- Central Zone

- Chhattisgarh

- Madhya Pradesh

- Uttar Pradesh

- EastZone

- Jharkhand

- WestBengal

- North-East Zone

- Nagaland

- Arunachal Pradesh

- Assam

- Sikkim
- North Zone

- Haryana

- Punjab

- South Zone

- Andhra Pradesh

- Telangana

- Karnataka

- WestZone

- Gujarat

- Maharashtra 
Furthermore, states were divided into developed and less developed states based on development indicators taken from the planning commission. The developed states include Andhra Pradesh, Telangana, West Bengal, Haryana, Maharashtra, and Gujarat. Less developed states include Uttar Pradesh, Nagaland, Sikkim, Arunachal Pradesh, and Assam. This would help in understanding whether development has any role in the effectiveness of the SHC at the farmer level.

\subsubsection{Structure of Data from Farmers:}

Structured questionnaires covering all the details pertaining to SHC were canvassed among the sample farmers. Besides, focus group discussions were conducted in the sample villages to get feedback from the communities. These groups include key informants and farmers not covered under individual survey and farmers who have not received the soil health card.

All the indicators collected from field survey were classified as inputs (financial and physical inputs under the project), activities (different activities organised under the scheme), outputs (actual outputs of the project), outcomes (whether generated outputs were used by the farmers), and impacts (what are the ultimate benefits to the farmers).

\subsubsection{Indicators of inputs of the SHC Scheme}

i. Procurement of maps (patwari / pahani maps) and field instruments (with GPS) and deployment of staff for collection of samples from farmers' fields.

ii. Methodology of soil sample collection (is the 10 ha grid for rainfed and 2.5 ha for irrigated adequate? Or are any improvements needed?).

iii. Status of soil testing facilities, including soil testing labs and mobile soil testing labs (geographical distribution, adequacy, access, and reachable)

iv. Availability of equipment (colour Photostat machine, standard paper for printing, and printing machines) and mechanisms for distribution of soil health cards to farmers.

v. Time lag between the release of funds and actual utilisation.

vi. Annual action plan versus implementation.

vii. Effectiveness of partnerships (operationalisation of the Public Private Partnership mode).

viii. Technical help from agricultural officers and allied sectors.

ix. Number of skilled staff engaged and whether there is any shortage of staff

x. Number of awareness camps and trainings and effectiveness of the campaign

xi. Reaching out to remote villages (in terms of samples collected and SHCs distributed and used)

xii. Identifying problematic soils, recommendations, and application of soil amendments

\subsubsection{Indicators of Activities under SHM}

i. Number of AEOs/ToTs trained under the scheme.

ii. Number of meetings, trainings, exposure visits, and demonstrations conducted.

iii. Number of soil testing laboratories strengthened (analysing capacity and utilisation).

iv. Number of soil testing labs equipped with micro nutrient testing facilities.

v. Number of referral labs established.

vi. Number of STLs equipped with Soil Test-based Crop Response (STCR).

vii. Number of farmers covered, samples collected, tested, and SHC printed. 


\subsubsection{Indicators of Outputs of the Scheme}

i. Number of SHCs distributed among farmers.

ii. Number of SHCs distributed among small and marginal farmers and SC/ST farmers (whether main field was located in their farm)

\subsubsection{Indicators of Outcomes}

i. Awareness about SHCs among the farmers

ii. Sources of information about soil health card and reliability

iii. Knowledge gain through attending demonstrations

iv. Understanding the content and SHC's recommendations

v. SHC portal usefulness for farmers; rating from 1 to 5 ( 1 is bad; 5 is excellent)

vi. Use of fertilisers according to the $\mathrm{SHC}$ recommendations

vii. Crops recommended in SHCs and actual crops sown by farmers

viii. Use of organic manure and biofertilisers by farmers

ix. Integrated Nutrient Management practices followed by farmers

x. Expectations of the farmers

xi. Overall opinion of farmers on SHC.

\subsubsection{Indicators of Socio-economic Impact}

i. Perceptions of the farmers towards the soil health card

ii. Increase in crop yields, reduction in fertiliser use and cost, and increase in profitability.

iii. Economic returns for farmers

\subsubsection{Information From Key Stakeholders and Secondary Data}

i. Scheme design (determining whether current grid of 10 ha for rainfed and 2.5 ha for irrigated is appropriate), components, activities, and outputs suitable to local implementation.

ii. Time lag in fund allocation, release, and utilisation at different stages.

iii. Gaps in physical and financial progress.

iv. Comparative analysis of the best performing states and other states in actual utilisation of SHCs by farmers.

v. Process monitoring and evaluation (institutional and administrative procedures, roles and responsibilities, maintenance of records) were analysed for learning across states. 


\section{Chapter V \\ Soil Health Card Scheme: Design, Coverage, and Impact}

\subsection{SHC Design and Status (Inputs/Activities and Outputs):}

Under the SHC scheme, the cropped area was divided into grids of 10 ha for rainfed and 2.5 ha for irrigated area, and only one soil sample was taken from each grid. The test results will be distributed to all the farmers whose area was falling under the grid. Based on the grid system, out of the total 14.1 crore hectares of net cropped area, with 52\% of area under rainfed ( 7.3 crore ha) and 73 lakh grid samples and with $48 \%$ area under irrigated (6.8 crore ha) and 2.72 crore grid samples, a total of 3.46 crore grid samples in two years will be the target. Every year, 1.72 crore grid samples need to be covered. This comes to on average 25,000 grid samples per district/year and 29 grid samples per village/year. With this, all 10.39 crore farmers will be covered in two years. Every year, 5.2 crore farmers need to be covered. Until now, the total samples entered are 1.56 crore, the number of farmers covered is 4.82 crore, samples tested are 1.23 crore and SHCs printed are 3.05 crore. This indicates that $46 \%$ of the total farmers were covered under the scheme at a national level, but only $29.3 \%$ received SHCs.

\section{Samples Collected}

State-wise samples collected were presented in map 6. It has been observed that the highest number of samples collected was in Kerala, with a maximum of 969 samples collected per 1,000 ha. Kerala is followed by Tamil Nadu, Gujarat, Uttar Pradesh, and Bihar, with 247 to 544 samples collected per 1,000 ha. Northern states such as Jammu \& Kashmir, Himachal Pradesh, Haryana and southern states of Telangana, Andhra Pradesh, and Maharashtra showed a moderate number of sample collection ranging between 157 and 246 samples/1,000 ha. A semi-moderate number of samples-i.e., 27-156 samples per 1,000 ha-was collected from most of the central, eastern, and north-eastern states such as Odisha, Madhya Pradesh, Arunachal Pradesh, and Assam. The lowest number of samples-i.e., 0- 26 samples per 1,000 ha-was collected in Manipur and the NCT of Delhi.

State-wise samples collected per 1,000 cultivators Map 7 show that Andhra Pradesh, Telangana, and Haryana came into green with higher samples collected per 1,000 cultivators. But Himachal Pradesh and Bihar came into red, with the lowest samples collected per 1,000 cultivators. Uttar Pradesh and West Bengal turned from light green to yellow.

\section{Samples tested}

State-wise samples tested per 1,000 ha are presented in map 8. It has been observed that the highest number of samples tested per 1,000 ha was in Kerala ( 727 samples tested per 1,000 ha). Kerala is followed by Tamil Nadu, Andhra Pradesh, Gujarat, and Haryana, with 206-316 samples tested per 1,000 ha. It can be seen that in most of the states (Telangana, Maharashtra, Karnataka, Madhya Pradesh, Chhattisgarh, etc.), the tested samples were in the range of 89-205 per 1,000 ha. In the rest of the states, viz. Rajasthan, Punjab, Jharkhand, and Jammu \& Kashmir, only 24-88 samples were tested per 1,000 ha. The lowest number of samples tested-i.e., 0-23 samples tested per 1,000 ha-is seen in NE states Assam and Manipur. 


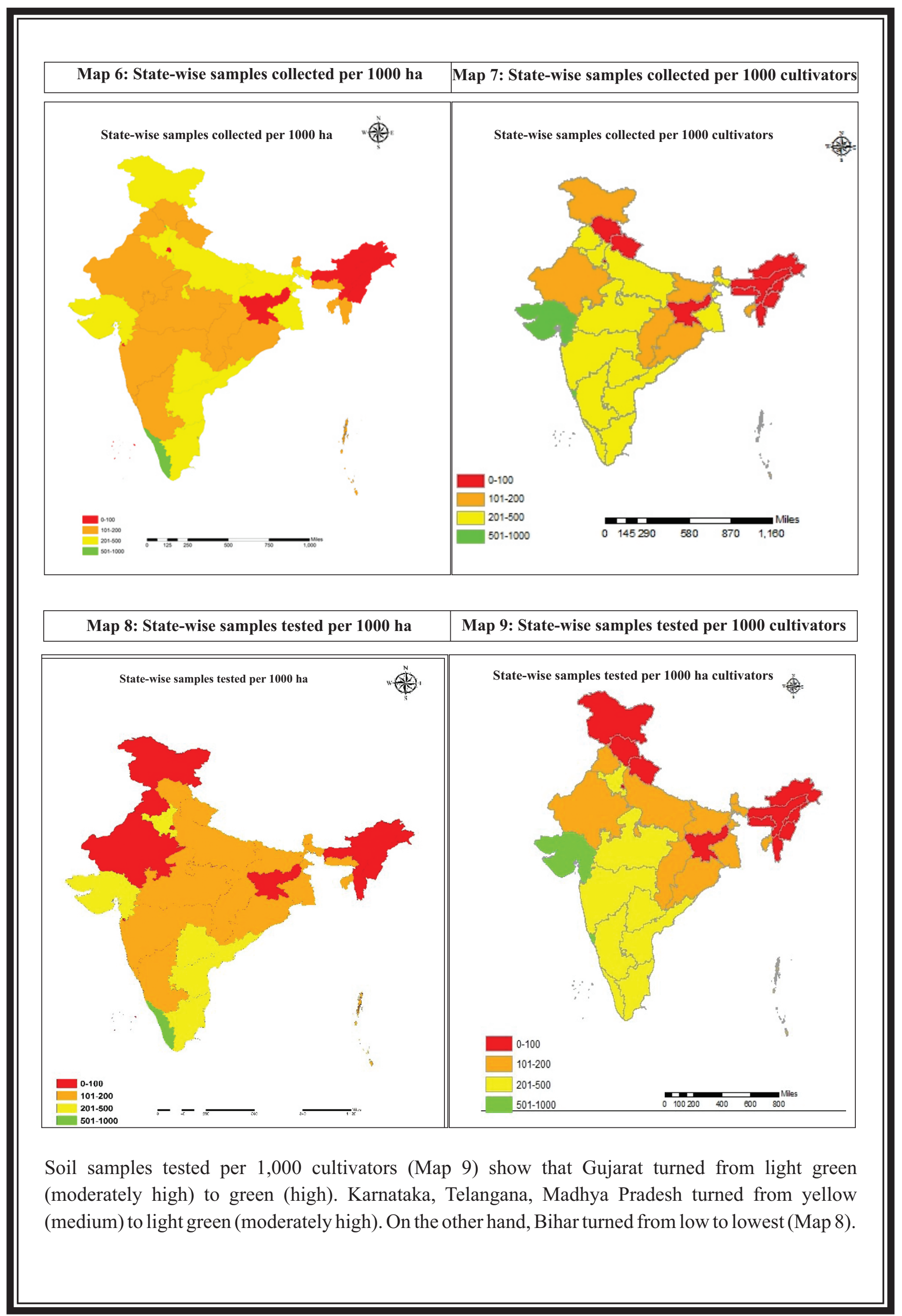




\section{SHC printed}

State-wise SHCs printed per 1,000 ha is depicted in map 10. It has been observed that the highest number of SHCs printed was in Kerala and Tamil Nadu, with above 1,000 SHCs printed per 1,000 ha. These two states are followed by Andhra Pradesh, Chhattisgarh, Himachal Pradesh, Uttarakhand, and Bihar, with about 687-1002 SHCs printed in the states. Rest of the states, such as Telangana, Maharashtra, Odisha, West Bengal, Uttar Pradesh, and parts of Jammu \& Kashmir displayed a moderate range of SHCs printed per 1,000 ha, i.e., in the range of 361-686. The low number of SHCs (i.e., 73-360 numbers per 1,000 ha) was seen in western states such as Rajasthan, Gujarat, Madhya Pradesh and northern states such as Punjab as well as Jharkhand. It was seen that the lowest number of SHCs printed, i.e., 0-72 SHCs printed per 1,000 ha was in North-eastern states, with the exception of Tripura and Nagaland, which showed about 361-686 SHCs printed per 1,000 ha.

A comparison of soil health cards printed per 1,000 ha and per 1,000 cultivators (Map 11) shows that there was a positive shift in Andhra Pradesh from light green (moderately high) to green (high), Telangana shifted from yellow to green (high). Gujarat and Madhya Pradesh shifted from low to medium, and Haryana moved from medium to moderately high. Bihar shifted from low to lowest (Map $10)$.

\section{Soil Health Cards Distributed}

State-wise SHCs distributed per 1,000 ha can be seen from map 12. It has been observed that the maximum number of SHCs distributed was in Kerala and Tamil Nadu (above 1,000 SHCs distributed per 1,000 ha). Andhra Pradesh, Chhattisgarh, Bihar, Himachal Pradesh, and Uttarakhand also showed a positive result, with 687-1001 SHCs distributed per 1,000 ha. These states are followed by Karnataka, Telangana, Odisha, West Bengal, Uttar Pradesh., and North-East states such as Sikkim, Nagaland, and Tripura, with 355-686 SHCs distributed per 1,000 ha. Northern, Western, and Northwestern states showed low range (74-354) of SHCs distributed per 1,000 ha. The lowest number of SHCs-i.e., 0-70-was distributed in Assam, Arunachal Pradesh, Mizoram, and Manipur.

When compared to SHCs distributed per 1,000 ha, SHCs distributed per 1,000 cultivators (Map 13) in Maharashtra, Karnataka, and Telangana shifted from yellow (medium) to light green (moderately high); Gujarat and Madhya Pradesh shifted from moderately low to medium; on the other hand, Kerala shifted from green (high) to yellow (medium), and Bihar shifted from moderately low to low. Himachal Pradesh and Uttarakhand's relative positions declined as well. Overall, the figures indicate that south India performed better, followed by central and western India. The performance was poor in the North-East (Map 12). 
Map 10: State-wise SHCs printed per 1000 ha Map 11: State-wise SHCs printed per 1000 cultivators

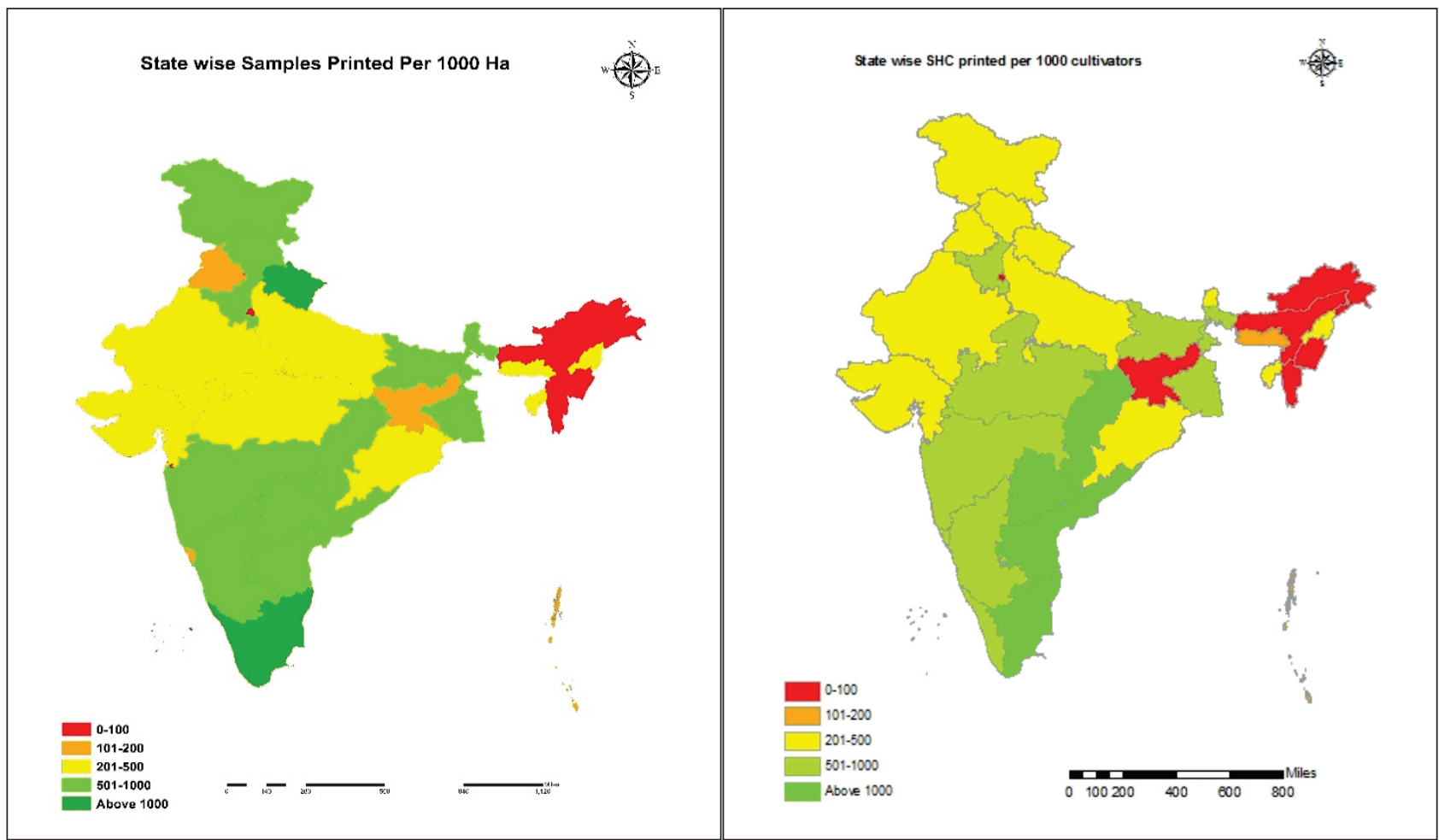

Map 12: State-wise SHCs distributed per 1000 ha Map 13: State-wise SHCs distributed per 1000 cultivators

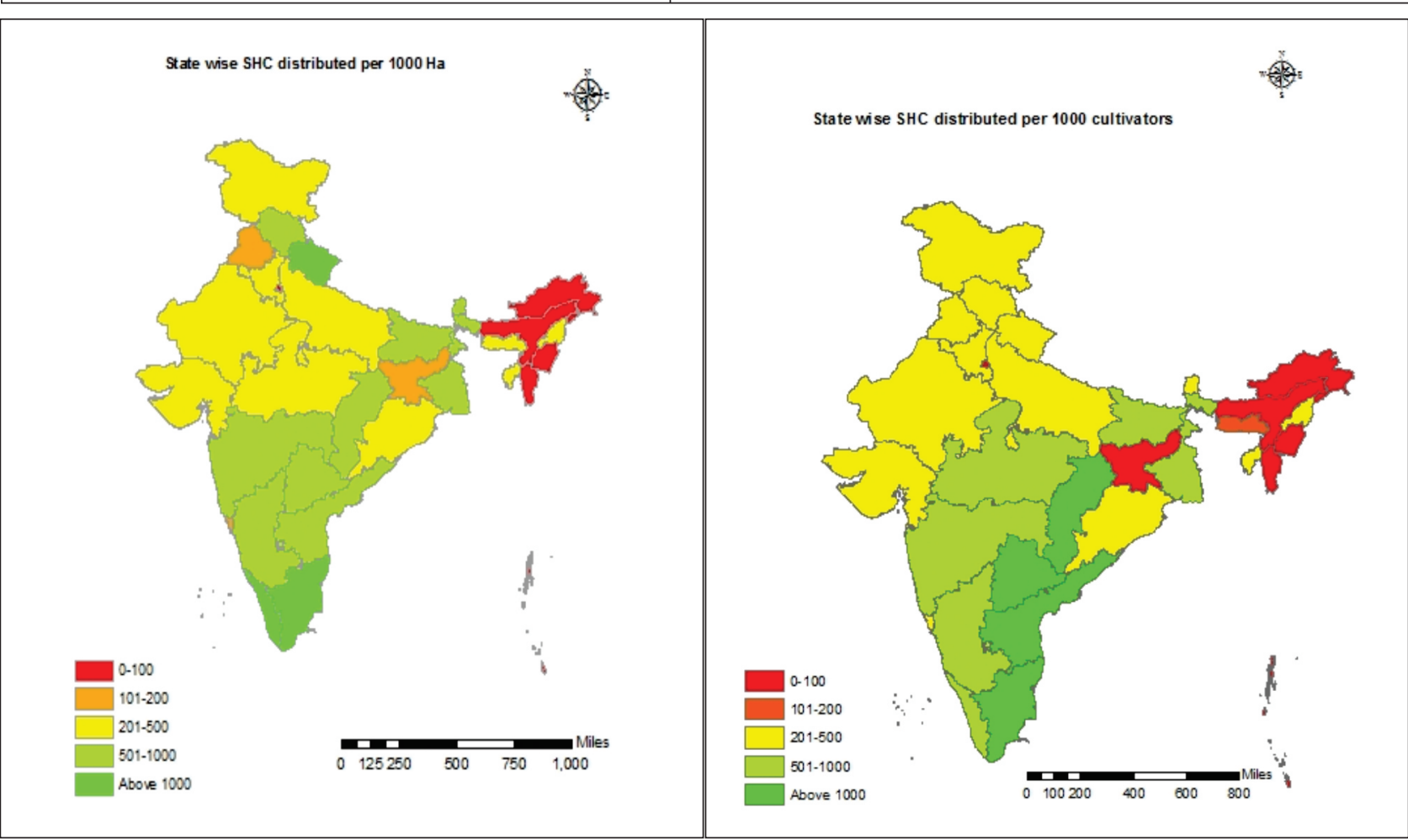




\section{District-wise Samples Collected, Tested and Printed}

District-wise data on soil samples collected (Map 14), tested (Map 15), and printed (Map 16) shows that although south-central and western Indian districts performed better, there is quite a bit of variation within the states. Even some districts in most backward states such as Bihar, Uttar Pradesh, and NorthEastern regions performed well, whereas some districts in south India performed poorly. This reflects the efficiency of district-level officers and other stakeholders. Besides, infrastructure plays an important role in the program.

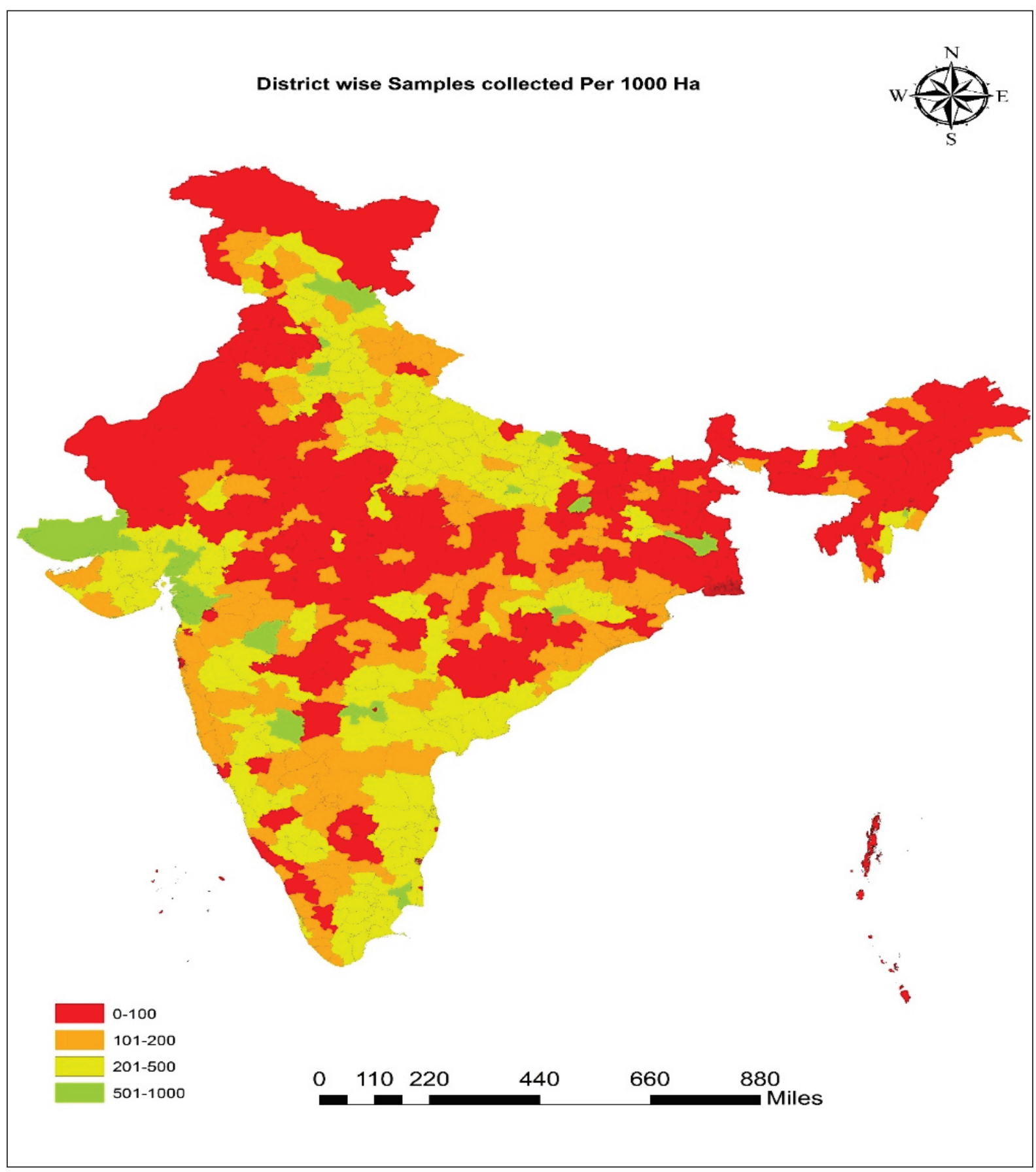

Map 14: District-wise samples collected per 1000 ha 


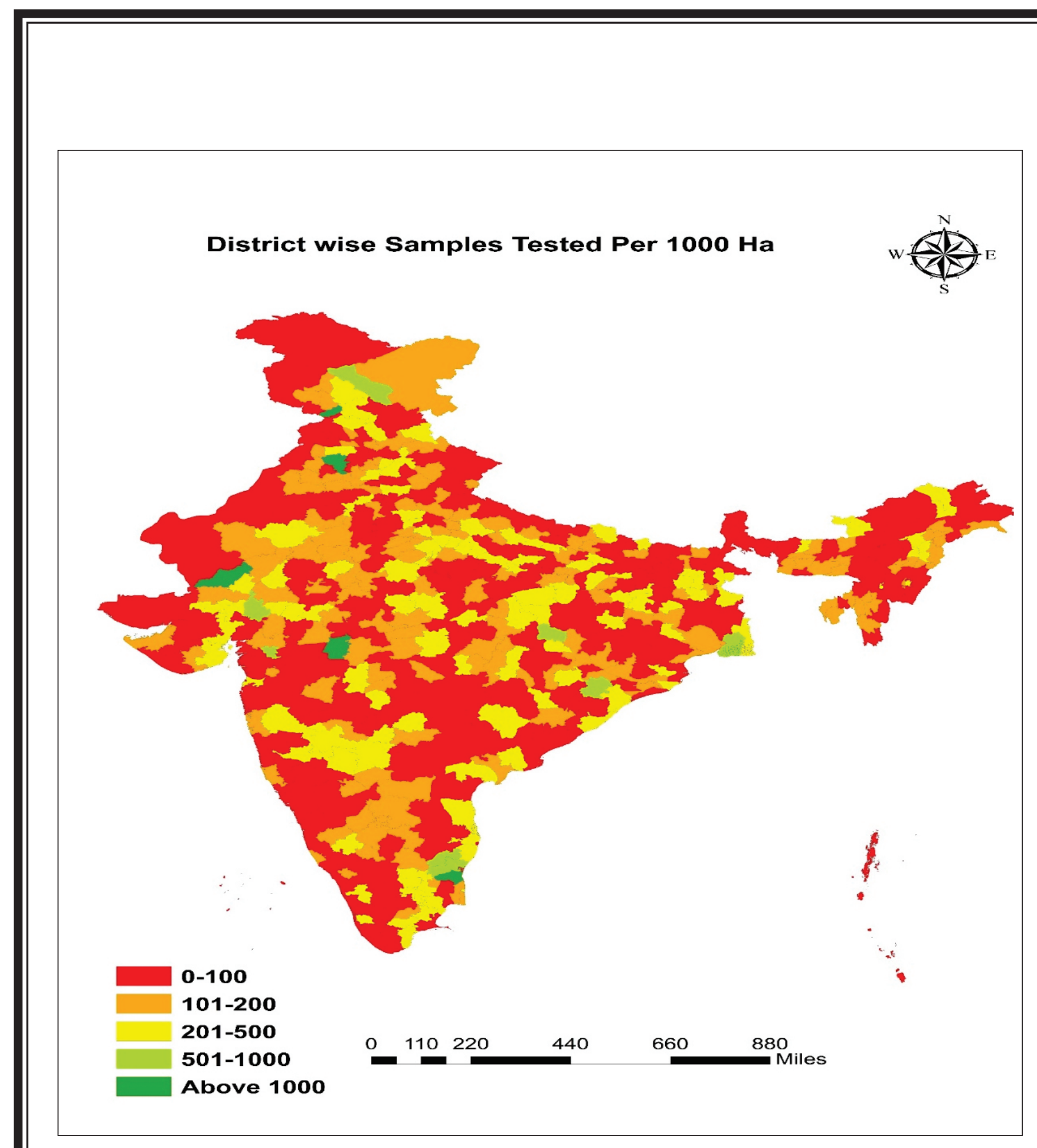

Map 15: District-wise samples tested per 1000 ha 


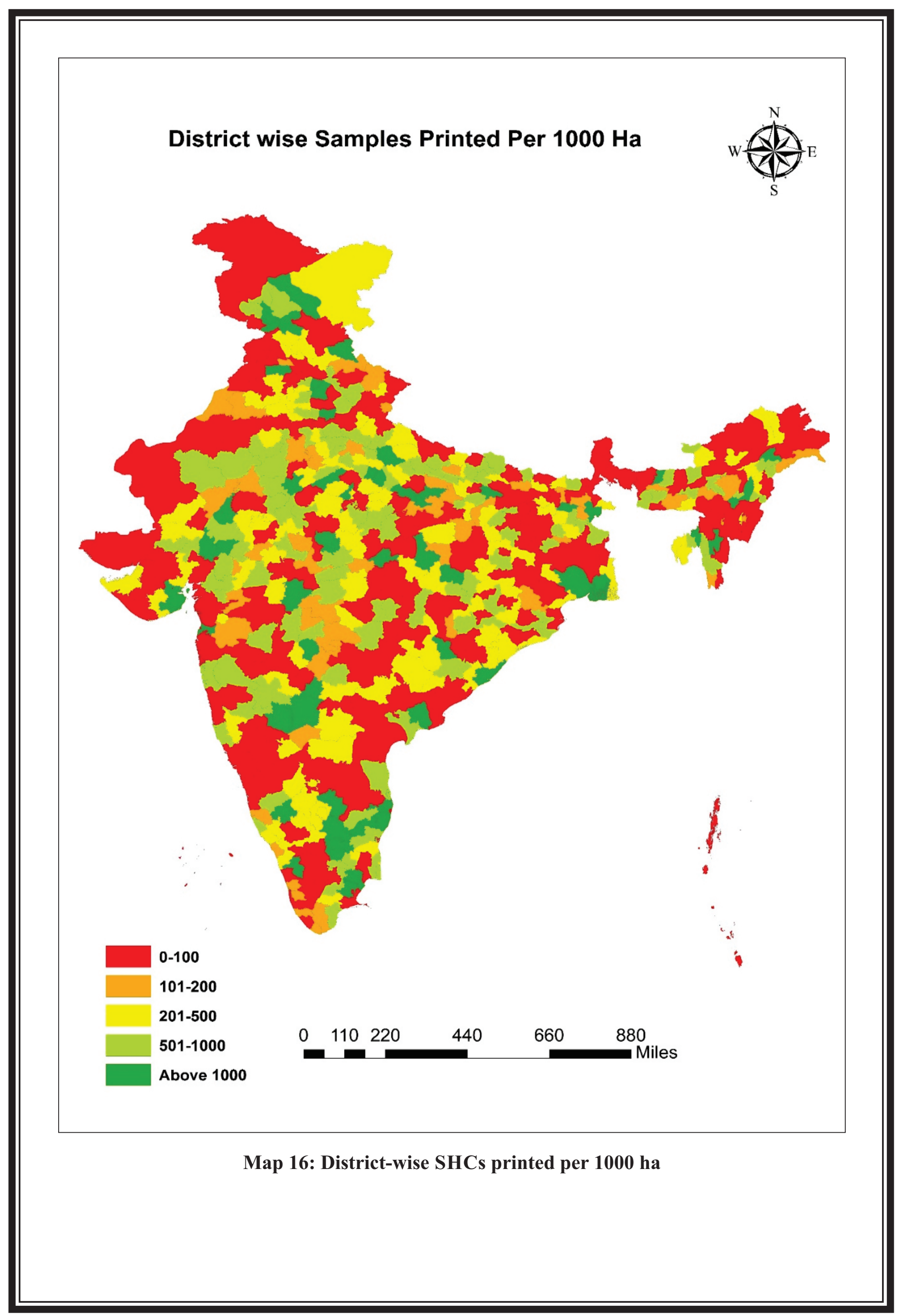




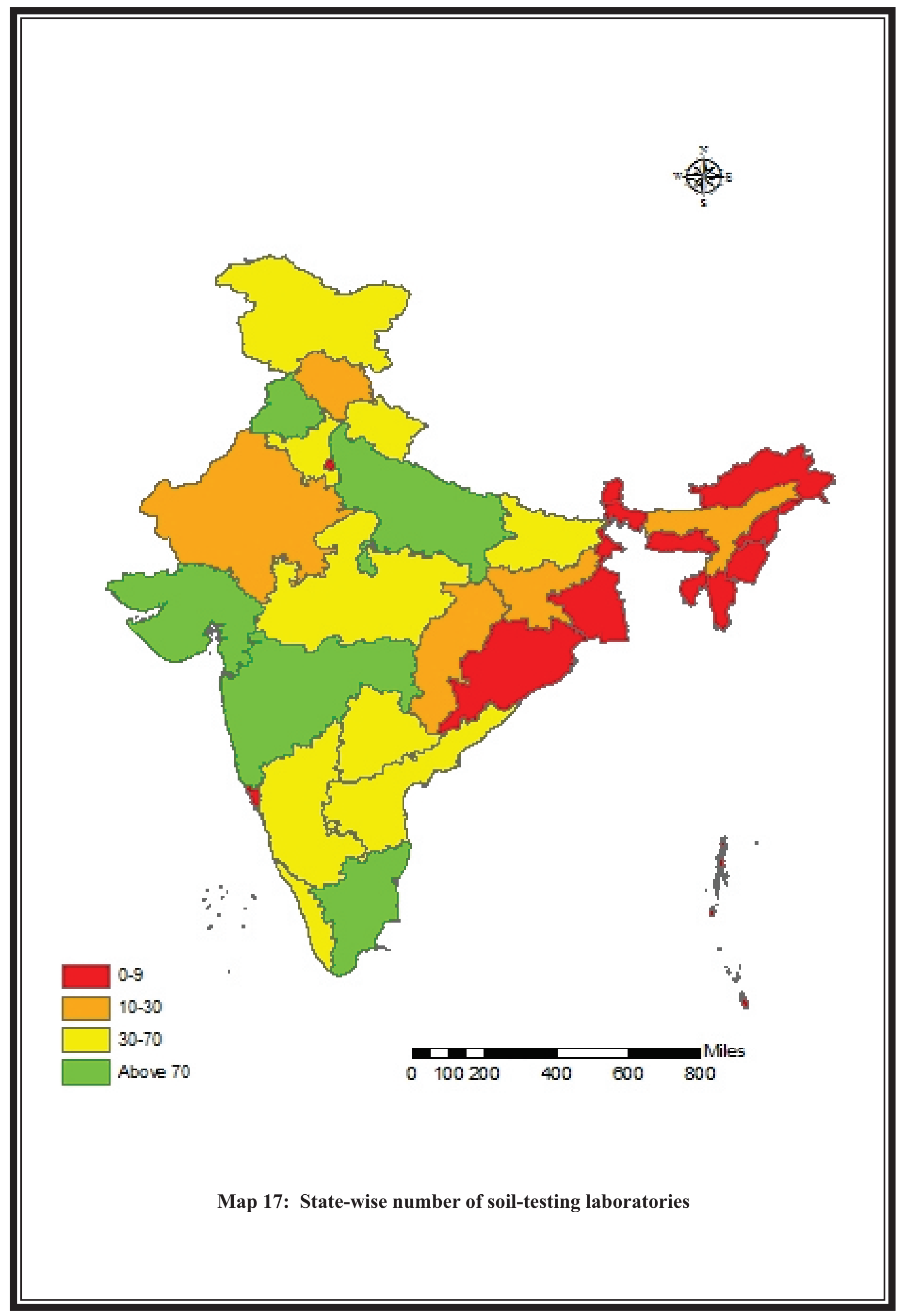


State-wise soil testing laboratories can be seen from map 17. It has been observed that the highest number of soil testing labs are found in Maharashtra and Tamil Nadu, with 156-344 labs. Gujarat and Uttar Pradesh stand second with 79-155 labs. Eastern (Chhattisgarh, Jharkhand, and West Bengal) and North-Eastern states have the lowest number (0-16) of soil testing labs. A majority of states, such as Telangana, Andhra Pradesh, Maharashtra, Karnataka, Odisha, Madhya Pradesh, Bihar, etc., have 4278 labs (moderate range). Kerala, Himachal Pradesh, Uttarakhand, and parts of Jammu \& Kashmir have 17-48 labs (semi-moderate range).

A number of soil testing laboratories per million ha are shown in map 18. This shows high density in Kerala, followed by Tamil Nadu, Himachal Pradesh, Jammu \& Kashmir, and Uttarakhand. The lowest density is in Rajasthan, West Bengal, and North-East. The density in Andhra Pradesh, Telangana, Maharashtra, Gujarat, Jharkhand, Bihar, Haryana, and Punjab is medium. District-wise labs are shown in map 19. In a few districts of Tamil Nadu, Kerala, Gujarat, Andhra Pradesh, Himachal Pradesh, Punjab, and Haryana, lab density for soil testing is high. However, in many of the north, central, eastern, and north-eastern districts, lab density for soil testing is quite low.

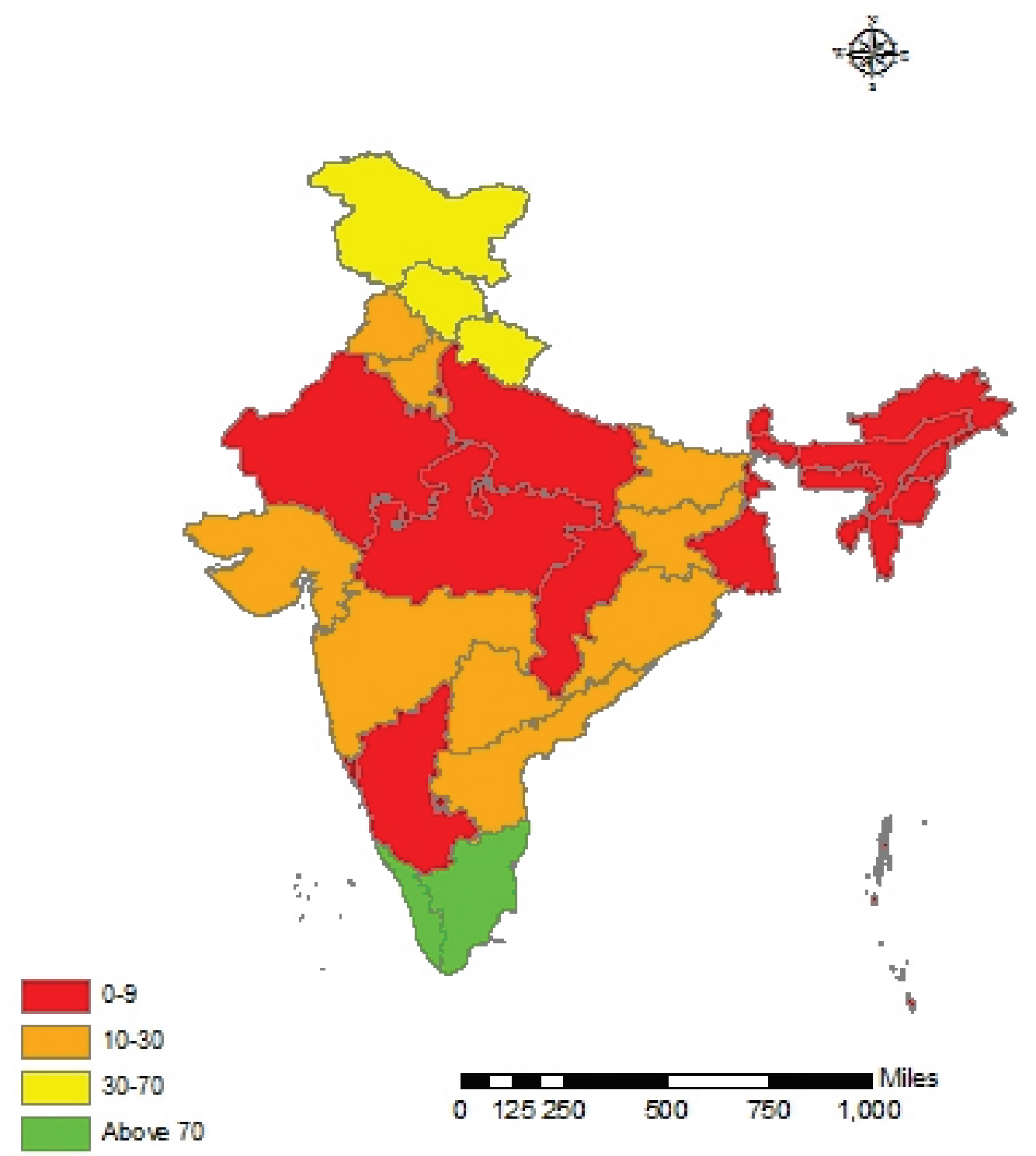

Map 18: State-wise soil testing labs per million hectares 


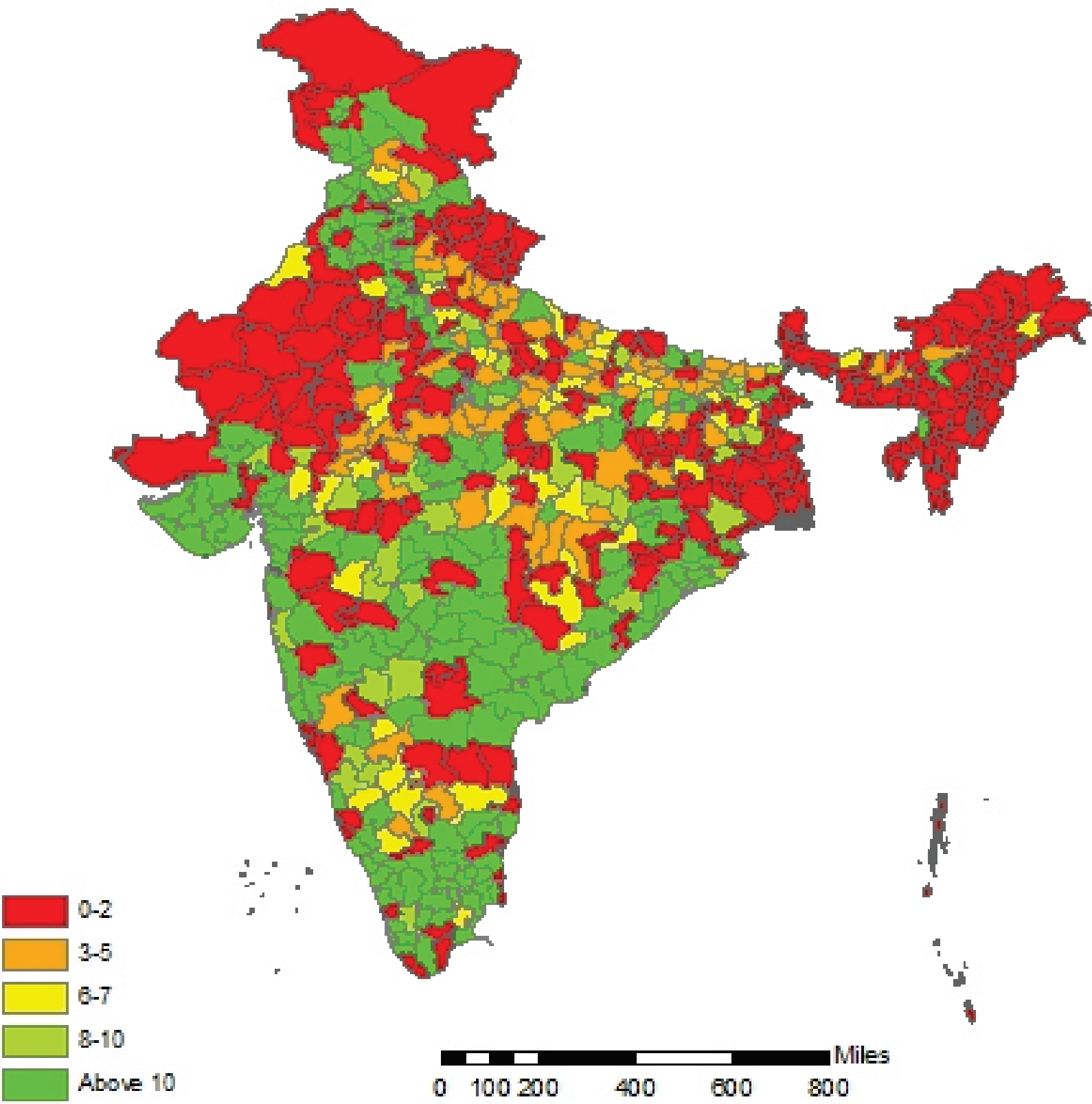

Map 19: District-wise STLs per million cultivators 


\subsection{Status of SHCs (Financial and Human Resource Allocation)}

In this section, the progress in the implementation of the SHC scheme is looked at from four important aspects, viz. financial allocations, infrastructure, human resources, and distribution of SHCs.

Allocations have been increasing over the years. In 2014-15, allocation under the project was Rs.13.68 crore, which increased to Rs.88.53 crore in 2015-16 and reached Rs. 169 crore in 2016-17. But the gap between allocation, release, and expenditure is increasing as well (Table 4A). The north zone has the highest gap. This could be attributed to the low capacities of spending. During the field visits, it has been observed that the block- and district-level agricultural officers are involved in multiple tasks assigned by state governments, and hence there was a need to have separate staff for soil health card management, especially in setting up, upgradation, and maintenance of soil testing labs. Field observations also indicated that there was frequent transfer of staff in soil testing labs to the field level and vice versa. Postings in soil testing laboratories is not a priority for many agricultural officers, although a few female agricultural officers have been interested in postings at STLs. To improve the quality of soil testing, there should be a separate cadre for working in soil testing labs. It has been indicated that female agricultural officers prefer working with STLs.

\section{Table 4A: Financial allocations and expenditure}

\begin{tabular}{|c|c|c|c|c|c|c|c|c|c|c|c|c|c|}
\hline \multicolumn{14}{|c|}{ State - wise Funds allocation, Release and Expenditure under Soil Health Cards Scheme in India (in lakhs) } \\
\hline \multirow[t]{2}{*}{ Zone } & \multicolumn{3}{|c|}{$2014-2015$} & \multicolumn{5}{|c|}{$2015-2016$} & \multicolumn{5}{|c|}{$2016-2017 *$} \\
\hline & $\begin{array}{l}\mathscr{\mathscr { J }} \\
\frac{\tilde{\Xi}}{\tilde{\Xi}} \\
\approx\end{array}$ & 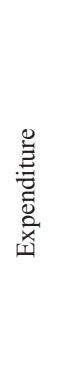 & 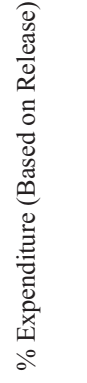 & 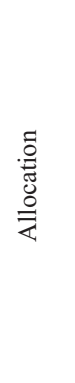 & 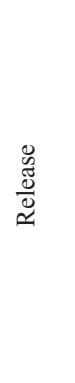 & 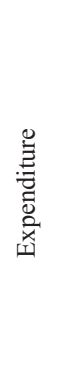 & 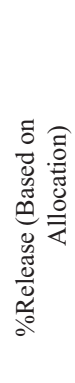 & 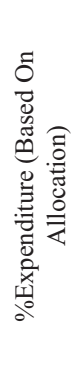 & 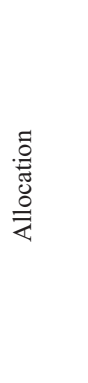 & 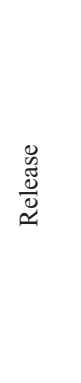 & 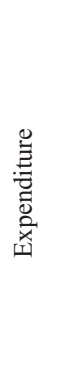 & 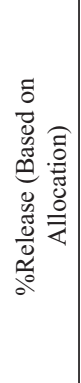 & 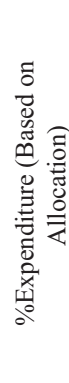 \\
\hline South & 218 & 218 & 100 & 1250 & 811 & 811 & 64 & 64 & 2331 & 1165 & 697 & 50 & 29 \\
\hline North & 389 & 371 & 95 & 2787 & 2005 & 492 & 71 & 17 & 5324 & 2442 & 0 & 4 & 0 \\
\hline West & 440 & 396 & 90 & 3348 & 2424 & 1817 & 72 & 54 & 6235 & 3117 & 1544 & 50 & 24 \\
\hline East & 234 & 219 & 93 & 1123 & 815 & 706 & 72 & 62 & 2274 & 407 & 88 & 17 & 3 \\
\hline $\begin{array}{c}\text { North } \\
\text { east }\end{array}$ & 88 & 37 & 42 & 344 & 194 & 51 & 56 & 14 & 768 & 0 & 0 & 0 & 0 \\
\hline INDIA & 1368 & 1241 & 91 & 8853 & 6248 & 3877 & 71 & 44 & 16932 & 7132 & 2329 & 42 & 14 \\
\hline
\end{tabular}

Note:* until November 2016 
Table 4B: Zone-wise analysis of funds allocation, release, and utilisation

\begin{tabular}{|c|c|c|c|c|c|c|}
\hline & \multicolumn{3}{|c|}{$2015-16$} & \multicolumn{3}{|c|}{ 2016-17 } \\
\hline Zone & $\begin{array}{l}\text { Allocation } \\
\text { (Rs. Lakh) }\end{array}$ & $\begin{array}{l}\text { Released } \\
\text { as \% of } \\
\text { allocation }\end{array}$ & $\begin{array}{l}\text { UC pending } \\
\text { as } \% \text { of } \\
\text { released }\end{array}$ & $\begin{array}{l}\text { Allocation } \\
\text { (Rs. Lakh) }\end{array}$ & $\begin{array}{l}\text { Released } \\
\text { as \% of } \\
\text { allocation }\end{array}$ & $\begin{array}{l}\text { UC pending } \\
\text { as \% of } \\
\text { released }\end{array}$ \\
\hline Central & 2528 & 43 & 17 & 4593 & 98 & 78 \\
\hline Eastern & 1094 & 77 & 58 & 2348 & 14 & 100 \\
\hline North & 1844 & 48 & 35 & 3303 & 13 & 59 \\
\hline $\begin{array}{l}\text { North - } \\
\text { Eastern }\end{array}$ & 292 & 64 & 0 & 1161 & 37 & 23 \\
\hline South & 1996 & 56 & 4 & 3829 & 56 & 23 \\
\hline Western & 1846 & 17 & 0 & 4056 & 42 & 32 \\
\hline Total & 9600 & 46 & 23 & 19290 & 50 & 54 \\
\hline
\end{tabular}

Source: Govt. of India letter dated July 27, 2017. There may be some mismatch between table 4 and 4A, as 4A is the updated one.

Table 4B shows that overall, only 46\% of the funds allocated were released in the year 2015-2016 and only 50\% were released in the year 2016-17. Utilisation certificate was pending for $23 \%$ of the funds released in the year 2015-16 and pending for 54\% of the funds released in the year 2016-17. In the year 2015-16, fund release was better in the eastern zone, followed by the north-east and north zones, while in the year 2016-17 it was better in central and southern zones. The funds utilisation needs to be increased across all the zones.

There are 1,244 soil testing laboratories in India, of which 1,048 are static and the remaining 196 are mobile. About $90 \%$ are under state governments, and the remaining are managed by the fertiliser industry. In addition, about 7,000 mini soil testing kits were distributed to block-level agricultural offices across the states. The present analysing capacity is 1.78 crore samples per annum with a utilisation of $75.8 \%$. The number of labs in India is 2016-17, as shown in Table 5.

In terms of analysing capacity (number of samples per annum), the South zone is at the top with about 7.0 million samples per annum, followed by the North zone (5.4 million samples) and the West zone (4.6 million samples). Among states, Tamil Nadu ranks first with 5.8 million samples, followed by Uttar Pradesh (4.1 million samples), Maharashtra (4.1 million samples), and Gujarat (1.4 million samples). 
Table 5: Infrastructure (number of labs) in 2016-17

\begin{tabular}{|c|c|c|c|c|c|c|c|c|c|c|}
\hline \multicolumn{8}{|c|}{ Number of Soil Testing Laboratories } & \multirow{3}{*}{$\begin{array}{l}\text { Analysing } \\
\text { Capacity } \\
\text { ('000 Nos.) }\end{array}$} & \multirow{3}{*}{\begin{tabular}{|c|} 
Number of \\
$\begin{array}{l}\text { Sample } \\
\text { Sanalysed }\end{array}$ \\
(000 \\
Nos.)
\end{tabular}} & \multirow{3}{*}{\begin{tabular}{|l|} 
Capacity \\
$\%$ Utilisation
\end{tabular}} \\
\hline \multirow[t]{2}{*}{ Zone/States/UTs } & \multicolumn{2}{|c|}{ State Govt. } & \multicolumn{2}{|c|}{$\begin{array}{l}\text { Fertiliser } \\
\text { Industry }\end{array}$} & \multicolumn{3}{|l|}{ Total } & & & \\
\hline & Static & Mobile & Static & Mobile & Static & Mobile & Total & & & \\
\hline East Zone & 105 & 37 & 1 & 2 & 106 & 39 & 145 & 959.4 & 769.2 & 80.2 \\
\hline $\begin{array}{l}\text { Arunachal } \\
\text { Pradesh }\end{array}$ & 5 & 3 & - & - & 5 & 3 & 8 & 9 & 7.9 & 87.3 \\
\hline Assam & 7 & 4 & - & - & 7 & 4 & 11 & 84 & 60.8 & 72.3 \\
\hline Bihar & 39 & - & - & - & 39 & - & 39 & 230 & 248.7 & 108.1 \\
\hline Jharkhand & 8 & - & - & - & 8 & - & 8 & 40 & 10.7 & 26.7 \\
\hline Odisha & 17 & 6 & 1 & - & 18 & 6 & 24 & 270 & 255.1 & 94.5 \\
\hline West Bengal & 10 & 8 & - & 2 & 10 & 10 & 20 & 112 & 60.4 & 53.8 \\
\hline Manipur & 4 & 4 & - & - & 4 & 4 & 8 & 40 & 1.4 & 3.4 \\
\hline Meghalaya & 3 & 3 & - & - & 3 & 3 & 6 & 30 & 27.7 & 92.2 \\
\hline Nagaland & 3 & - & - & - & 3 & - & 3 & 45 & 14.3 & 31.8 \\
\hline Sikkim & 4 & 2 & - & - & 4 & 2 & 6 & 37 & 39.9 & 107.8 \\
\hline Tripura & 2 & 4 & - & - & 2 & 4 & 6 & 35 & 17.5 & 50.1 \\
\hline Mizoram & 3 & 3 & - & - & 3 & 3 & 6 & 27 & 25 & 92.6 \\
\hline North Zone & 377 & 45 & 9 & 6 & 386 & 51 & 437 & 5444 & 4198 & 77 \\
\hline Haryana & 35 & 3 & 2 & - & 37 & 3 & 40 & 365 & 247.9 & 67.9 \\
\hline Himachal Pradesh & 11 & 4 & - & - & 11 & 4 & 15 & 125 & 124.4 & 99.5 \\
\hline $\begin{array}{l}\text { Jammu and } \\
\text { Kashmir }\end{array}$ & 8 & 5 & - & - & 8 & 5 & 13 & 52 & 43.6 & 83.9 \\
\hline Punjab & 54 & 12 & 2 & 3 & 56 & 15 & 71 & 631.5 & 282.1 & 44.7 \\
\hline Uttar Pradesh & 255 & 18 & 5 & 3 & 260 & 21 & 281 & 4159.5 & 3404.6 & 81.9 \\
\hline Uttarakhand & 13 & 3 & - & - & 13 & 3 & 16 & 106.5 & 95.2 & 89.4 \\
\hline Delhi & 1 & - & - & - & 1 & - & 1 & 5 & 0.5 & 9.2 \\
\hline South Zone & 157 & 32 & 35 & 4 & 192 & 36 & 228 & 6727.4 & 5503.2 & 81.8 \\
\hline Andhra Pradesh & 55 & 5 & 27 & 1 & 82 & 6 & 88 & 413 & 345.8 & 83.7 \\
\hline Karnataka & 56 & - & 6 & 2 & 62 & 2 & 64 & 295.7 & 194.8 & 65.9 \\
\hline Kerala & 14 & 11 & 1 & - & 15 & 11 & 26 & 218 & 134.7 & 61.8 \\
\hline Tamil Nadu & 30 & 16 & 1 & 1 & 31 & 17 & 48 & 5796.7 & 4823.5 & 83.2 \\
\hline Pondicherry & 2 & - & - & - & 2 & - & 2 & 4 & 4.4 & 110.3 \\
\hline West Zone & 348 & 59 & 16 & 11 & 364 & 70 & 434 & 4695.4 & \begin{tabular}{|l|}
3046.6 \\
\end{tabular} & 64.9 \\
\hline Gujarat & 132 & 2 & 4 & 1 & 136 & 3 & 139 & 1412 & 1199.1 & 84.9 \\
\hline Madhya & 50 & 7 & 2 & 4 & 52 & 11 & 63 & 378 & 346.5 & 91.7 \\
\hline $\begin{array}{l}\text { Pradesh } \\
\text { Chhattisgarh }\end{array}$ & 7 & 5 & 1 & - & 8 & 5 & 13 & 105 & 116 & 110.5 \\
\hline Maharashtra & 123 & 23 & 8 & 4 & 131 & 27 & 158 & 2241.4 & 967.3 & 43.2 \\
\hline Rajasthan & 34 & 22 & 1 & 2 & 35 & 24 & 59 & 536 & 402.7 & 75.1 \\
\hline Goa & 2 & - & - & - & 2 & - & 2 & 23 & 15 & 65 \\
\hline India & 987 & 173 & 61 & 23 & 1048 & 196 & 1244 & $1,78,27$ & $1,35,17$ & 75.8 \\
\hline
\end{tabular}

Source: The Fertiliser Association of India. (16851); Andhra Pradesh Figures include Telangana

Capacity utilisation is more than $90 \%$ in Chhattisgarh, Pondicherry, Bihar, Sikkim, Himachal Pradesh, Odisha, Mizoram, Meghalaya, Madhya Pradesh and Uttarakhand, but less than 50\% in Manipur, Jharkhand, Nagaland, Maharashtra and Punjab. Low capacity utilisation of funds and infrastructure could be due to lack of human resources. Since this is a new central scheme, state governments have taken the time to streamline and coordinate the activities, especially in north and eastern zones. The performance is better in southern and western zones, which is attributed to the efficient use of already 
existing skilled workers, labs, and improvements in lab capacities, especially the setting up of mini labs, although focus group interactions reveal that the results of mini labs are not as accurate as those of full-fledged labs.

Focus group interactions with local agriculture officers indicated that there was a severe shortage of infrastructure (labs) and skilled workers. Although soil sample collection, testing, and distribution of soil test values is done by multiple agencies (including KVKs, SAUs and ICAR, and some private companies such as Nagarjuna Fertilisers), under the SHC scheme, the burden is exclusively on the State Department of Agriculture. Most of the soil sample collection work is carried out by contractual agricultural extension officers, who work under the block-level agricultural officers. In developed states such as Punjab, extension officers were provided with GPS-enabled tablets. There was no statistical database on the total staff involved in the soil sample collection and testing. As the soil sample collection was seasonal (only from April and May), all the staff below the block level was engaged in the soil sample collection. Soil testing requires specialised labs and skills that are not widely available at the block level and hence sent to district-level soil testing labs. Some estimates show that at the national level, the gap between requirement and availability is $-148 \%$. The gap is the highest in the South zone, followed by west and north-east zones. The gap could be much higher if we include other activities as well, i.e., after sample collection drying, grinding, sieving, etc. Soil sample collection should be done in the campaign mode by involving the staff of all agricultural and allied department employees, as this activity is exclusively carried out during April-May. There is a need for developing a separate soil testing cadre and strengthening district-level soil testing labs with an estimated cost of Rs. 4-5 crore per district. Overall, it requires Rs. 2,800 to set up one state-of-the-art lab in each of 700 districts in India. Field-level observations indicated that the mini lab results are not too reliable, take a lot of time, and are also not suitable for large-scale testing. Mini labs are more suitable in remote and tribal villages as well as for the analysis of highly volatile nitrogen and other major elements. They should complement rather than substitute full-fledged labs.

Under the SHC scheme, the cropped area was divided into grids of 10 ha for rainfed and 2.5 ha for irrigated. One soil sample from each grid will be taken and test results will be distributed to all the farmers whose land falls under the grid. Based on the grid system, out of the total 14.1 crore hectare of net cropped area, 73 lakh grid samples were to be collected to cover 7.3 crore ha area under rainfed situations and 2.7 crore grid samples were to be covered under 6.8 crore ha irrigated land, with a total of 3.46 crore grid samples to be collected in two years, i.e., 1.72 crore grid samples per year. On average, this comes to 25,000 grid samples per district/year or 29 grid samples per village/year. With this, all 14 crore farmers will be covered in two years.

Under cycle 1, 2.54 crore samples were collected, 2.36 crore samples tested, 9.62 crore soil health cards printed, but only 9.33 crore SHCs distributed. This indicates that $100 \%$ target was archived in sample collection, $93 \%$ of the target was achieved in soil testing, but only $80 \%$ of the target was achieved in SHC printing. $97 \%$ of the SHCs printed have been distributed among the farmers as on September 24, 2017 (Table 6A). The progress in samples collected, tested, printed, and distributed in a short span is gigantic. However, the gap in the number of farmers covered and the number of SHCs printed and distributed needs to be bridged with proper quality checks at all stages. The progress under cycle 2 is shown in table $6 \mathrm{~B}$. 
Table 6A: Samples entered, farmers covered, samples tested, and SHCs printed (Cycle1) (in Lakhs)

\begin{tabular}{|c|c|c|c|c|c|c|c|c|c|c|c|}
\hline Sl.No. & State & $\begin{array}{l}\text { Cumulative } \\
\text { Target for } \\
\text { Soil Samples } \\
\text { Collection \& } \\
\text { Testing during } \\
\text { Cycle-I } \\
(2015-16 \text { \& } \\
2016-17)\end{array}$ & $\begin{array}{l}\text { No. of } \\
\text { Samples } \\
\text { Collected } \\
\text { (Cycle - I) }\end{array}$ & $\begin{array}{l}\text { \% Progress } \\
\text { of Soil } \\
\text { Samples } \\
\text { Collected } \\
\text { (Cycle - I) }\end{array}$ & $\begin{array}{l}\text { No. of } \\
\text { Samples } \\
\text { Tested } \\
\text { (Cycle - I) }\end{array}$ & $\begin{array}{l}\% \text { Progress } \\
\text { of Soil } \\
\text { Samples } \\
\text { Tested } \\
(\text { Cycle - I) }\end{array}$ & \begin{tabular}{|l|} 
Cumulative \\
Target for \\
Printing \& \\
Distribution \\
of SHCs for \\
Cycle - I \\
$(2015-16$ \& \\
$2016-17)$
\end{tabular} & $\begin{array}{l}\text { No. of } \\
\text { SHCs } \\
\text { Printed } \\
\text { (Cycle - I) }\end{array}$ & $\begin{array}{l}\text { \% Progress } \\
\text { of SHCs } \\
\text { Printed } \\
\text { (Cycle - I) }\end{array}$ & $\begin{array}{l}\text { No. of SHCs } \\
\text { Distributed } \\
\text { (Cycle - I) }\end{array}$ & $\begin{array}{l}\% \text { Progress } \\
\text { of SHCs } \\
\text { Distributed } \\
\text { (Cycle - I) }\end{array}$ \\
\hline \multicolumn{12}{|c|}{ Group - I } \\
\hline 1 & Uttar Pradesh & 47.7 & 47.7 & 100 & 39.34 & 82 & 233.25 & 106.24 & 46 & 106.24 & 100 \\
\hline 2 & Maharashtra & 23.5 & 23.5 & 100 & 23.47 & 100 & 129.77 & 129.77 & 100 & 129.77 & 100 \\
\hline 3 & Madhya Pradesh & 23.1 & 23.1 & 100 & 23.14 & 100 & 88.72 & 88.72 & 100 & 88.72 & 100 \\
\hline 4 & Rajasthan & 23.1 & 23.1 & 100 & 23.08 & 100 & 68.86 & 69.56 & 101 & 68.67 & 99 \\
\hline \multicolumn{12}{|c|}{ Group - I I } \\
\hline 1 & Karnataka & 16.7 & 16.7 & 100 & 16.66 & 100 & 78.32 & 78.32 & 100 & 78.32 & 100 \\
\hline 2 & Gujarat & 15.9 & 15.9 & 100 & 15.89 & 100 & 51.09 & 48.61 & 95 & 48.61 & 100 \\
\hline 3 & Andhra Pradesh & 13.5 & 13.5 & 100 & 13.48 & 100 & 74.55 & 74.55 & 100 & 74.55 & 100 \\
\hline 4 & Bihar & 13.1 & 13.1 & 100 & 10.85 & 83 & 72.36 & 48.02 & 66 & 48.02 & 100 \\
\hline 5 & West Bengal & 13.0 & 13.0 & 100 & 13.00 & 100 & 50.41 & 41.08 & 81 & 41.00 & 100 \\
\hline 6 & Tamil Nadu & 12.7 & 12.7 & 100 & 12.75 & 100 & 70.00 & 70.00 & 100 & 70.00 & 100 \\
\hline 7 & Telangana & 10.3 & 10.3 & 100 & 10.35 & 100 & 57.21 & 57.21 & 100 & 57.21 & 100 \\
\hline \multicolumn{12}{|c|}{ Group - III } \\
\hline 1 & Punjab & 8.4 & 8.4 & 100 & 4.11 & 49 & 46.20 & 8.59 & 19 & 8.52 & 99 \\
\hline 2 & Haryana & 7.9 & 7.9 & 100 & 7.89 & 100 & 43.61 & 28.92 & 66 & 16.35 & 57 \\
\hline 3 & Chhattisgarh & 7.0 & 7.0 & 100 & 7.04 & 100 & 38.91 & 41.14 & 106 & 38.91 & 95 \\
\hline 4 & Odisha & 6.7 & 6.7 & 100 & 6.69 & 100 & 36.97 & 32.16 & 87 & 24.03 & 75 \\
\hline \multicolumn{12}{|c|}{ Group - IV } \\
\hline 1 & Kerala & 1.3 & 1.3 & 100 & 1.28 & 100 & 7.05 & 7.05 & 100 & 7.05 & 100 \\
\hline 2 & Goa & 0.3 & 0.3 & 100 & 0.25 & 100 & 0.25 & 0.20 & 81 & 0.20 & 100 \\
\hline 3 & Uttarakhand & 1.4 & 1.4 & 100 & 1.36 & 100 & 7.50 & 7.50 & 100 & 7.50 & 100 \\
\hline 4 & HP & 0.7 & $\sigma$ & 100 & 0.70 & 100 & 3.85 & 5.43 & 141 & 3.85 & 71 \\
\hline 5 & $J \& K$ & 1.7 & 1.7 & 100 & 1.40 & 85 & 9.14 & 5.11 & 56 & 2.50 & 49 \\
\hline 6 & Jharkhand & 1.2 & 1.2 & 100 & 1.15 & 100 & 6.38 & 6.38 & 100 & 5.23 & 82 \\
\hline 7 & Arunachal Pradesh & 0.2 & 0.2 & 100 & 0.19 & 93 & 1.14 & 0.14 & 12 & 0.11 & 80 \\
\hline 8 & Assam & 2.8 & 2.8 & 100 & 0.85 & 30 & 15.41 & 1.74 & 11 & 1.58 & 91 \\
\hline 9 & Manipur & 0.2 & 0.2 & 100 & 0.06 & 31 & 1.15 & 0.06 & 5 & 0.05 & 90 \\
\hline 10 & Meghalaya & 0.4 & 0.4 & 100 & 0.39 & 100 & 2.10 & 2.10 & 100 & 2.10 & 100 \\
\hline 11 & Mizoram & 0.1 & 0.1 & 100 & 0.10 & 86 & 0.12 & 0.08 & 69 & 0.08 & 100 \\
\hline 12 & Nagaland & 0.3 & 0.3 & 100 & 0.33 & 100 & 1.85 & 1.85 & 100 & 1.85 & 100 \\
\hline 13 & Sikkim & 0.1 & 0.1 & 100 & 0.13 & 100 & 0.46 & 0.46 & 100 & 0.46 & 100 \\
\hline 14 & Tripura & 0.3 & 0.3 & 100 & 0.33 & 100 & 1.18 & 1.18 & 100 & 1.18 & 100 \\
\hline \multicolumn{12}{|c|}{ Union Territories } \\
\hline 1 & $\begin{array}{l}\text { Andaman \& } \\
\text { Nicobar }\end{array}$ & 0.01 & 0.01 & 100 & 0.01 & 100 & 0.08 & 0.02 & 27 & 0.02 & 90 \\
\hline 2 & $\begin{array}{l}\text { Dadra \& Nagar } \\
\text { Haveli }\end{array}$ & 0.02 & 0.02 & 100 & 0.02 & 100 & 0.12 & 0.00 & 0 & 0.00 & \\
\hline 3 & Puducherry & 0.04 & 0.04 & 100 & 0.04 & 100 & 0.20 & 0.20 & 100 & 0.20 & 100 \\
\hline \multicolumn{2}{|c|}{ Total } & 254 & 254 & 100 & 236 & 93 & 1198 & 962 & 80 & 933 & 97 \\
\hline
\end{tabular}


Table 6B: Samples entered, farmers covered, samples tested, and SHCs printed (Cycle-2) (In Lakhs)

\begin{tabular}{|c|c|c|c|c|c|c|c|c|c|c|c|}
\hline Sl.No. & State & $\begin{array}{l}\text { Target for } \\
\text { Soil Samples } \\
\text { Collection } \\
\text { \& Testing } \\
\text { during } \\
\text { Cycle - II } \\
(2017-18)\end{array}$ & $\begin{array}{c}\text { No. of } \\
\text { Samples } \\
\text { Collected } \\
\text { (Cycle - II) }\end{array}$ & $\begin{array}{c}\% \text { Progress } \\
\text { of Soil } \\
\text { Samples } \\
\text { Collected } \\
\text { (Cycle - II) }\end{array}$ & $\begin{array}{c}\text { No. of } \\
\text { Samples } \\
\text { Tested } \\
\text { (Cycle } \\
\text {-II) }\end{array}$ & $\begin{array}{c}\% \text { Progress } \\
\text { of Soil } \\
\text { Samples } \\
\text { Tested } \\
\text { (Cycle - II) }\end{array}$ & \begin{tabular}{|c} 
Target for \\
Printing \& \\
Distribution \\
of SHCs for \\
Cycle - II \\
$(2016$-18)
\end{tabular} & $\begin{array}{c}\text { No. of } \\
\text { SHCs } \\
\text { Printed } \\
\text { (Cycle - II) }\end{array}$ & $\begin{array}{c}\% \text { Progress } \\
\text { of SHCs } \\
\text { Printed } \\
\text { (Cycle - II) }\end{array}$ & $\begin{array}{c}\text { No. of SHCs } \\
\text { Distributed } \\
\text { (Cycle - II) }\end{array}$ & $\begin{array}{l}\% \text { Progress } \\
\text { of SHCs } \\
\text { Distributed } \\
(\text { Cycle }- \text { I) }\end{array}$ \\
\hline \multicolumn{12}{|c|}{ Group - I } \\
\hline 1 & Uttar Pradesh & 23.85 & 12.67 & 53 & 3.44 & 14 & 116.63 & 1.96 & 2 & 1.96 & 2 \\
\hline 2 & Maharashtra & 11.74 & 14.31 & 100 & 6.87 & 59 & 64.89 & 3.57 & 6 & 3.57 & 6 \\
\hline 3 & $\begin{array}{l}\text { Madhya } \\
\text { Pradesh }\end{array}$ & 11.57 & 6.63 & 57 & 2.93 & 25 & 44.36 & 8.82 & 20 & 8.80 & 20 \\
\hline 4 & Rajasthan & 11.54 & 6.40 & 55 & 0.00 & 0 & 34.43 & 0.00 & 0 & 0.00 & 0 \\
\hline \multicolumn{12}{|c|}{ Group - II } \\
\hline 1 & Karnataka & 8.33 & 4.27 & 51 & 3.21 & 39 & 39.16 & 518 & 15 & 2.32 & 6 \\
\hline 2 & Gujarat & 7.95 & 8.14 & 100 & 0.18 & 2 & 25.54 & 0.00 & 0 & 0.00 & 0 \\
\hline 3 & $\begin{array}{l}\text { Andhra } \\
\text { Pradesh }\end{array}$ & 6.74 & 2.54 & 38 & 2.54 & 38 & 37.28 & 10.12 & 27 & 10.12 & 27 \\
\hline 4 & Bihar & 6.54 & 2.20 & 34 & 0.94 & 14 & 36.18 & 2.12 & 6 & 2.12 & 6 \\
\hline 5 & West Bengal & 6.50 & 2.99 & 46 & 0.90 & 14 & 25.20 & 2.79 & 11 & 0.00 & 0 \\
\hline 6 & Tamil Nadu & 6.37 & 6.40 & 100 & 3.09 & 48 & 35.00 & 0.00 & 0 & 0.00 & 0 \\
\hline 7 & Telangana & 5.17 & 4.01 & 78 & 0.76 & 15 & 28.60 & 0.00 & 0 & 0.00 & 0 \\
\hline \multicolumn{12}{|c|}{ Group - III } \\
\hline 1 & Punjab & 4.18 & 1.15 & 27 & 0.00 & 0 & 23.10 & 0.00 & 0 & 0.00 & 0 \\
\hline 2 & Haryana & 3.94 & 2.77 & 70 & 0.04 & 1 & 21.80 & 0.04 & 0 & 0.02 & 0 \\
\hline 3 & Chhattisgarh & 3.52 & 3.10 & 88 & 1.90 & 54 & 19.45 & 4.56 & 23 & 4.08 & 21 \\
\hline 4 & Odisha & 3.34 & 1.80 & 54 & 0.83 & 25 & 18.48 & 0.91 & 5 & 0.76 & 4 \\
\hline \multicolumn{12}{|c|}{ Group - IV } \\
\hline 1 & Kerala & 0.64 & 0.00 & 0 & 0.00 & 0 & 3.53 & 0.00 & 0 & 0.00 & 0 \\
\hline 2 & Goa & 0.13 & 0.07 & 54 & 0.04 & 36 & 0.13 & 0.04 & 34 & 0.04 & 34 \\
\hline 3 & Uttarakhand & 0.68 & 0.44 & 65 & 0.31 & 46 & 3.75 & 0.69 & 18 & D1 & 14 \\
\hline 4 & $\begin{array}{l}\text { Himachal } \\
\text { Pradesh }\end{array}$ & 0.35 & 0.43 & 100 & 0.42 & 100 & 1.93 & 2.42 & 100 & 2.42 & 100 \\
\hline 5 & $\mathrm{~J} \& \mathrm{~K}$ & 0.83 & 0.05 & 6 & 0.00 & 1 & 4.57 & 0.00 & 0 & 0.00 & 0 \\
\hline 6 & Jharkhand & 0.58 & 0.47 & 81 & 0.34 & 58 & 3.19 & 0.55 & 17 & 0.55 & 17 \\
\hline 7 & $\begin{array}{l}\text { Arunachal } \\
\text { Pradesh }\end{array}$ & 0.10 & 0.00 & 0 & 0.00 & 0 & 0.57 & 0.00 & 0 & 0.00 & 0 \\
\hline 8 & Assam & 1.39 & 0.00 & 0 & 0 & 0 & 7.70 & 0.00 & 0 & 0.00 & 0 \\
\hline 9 & Manipur & 0.10 & 0.00 & 0 & 0.00 & 0 & 0.57 & 0.00 & 0 & 0.00 & 0 \\
\hline 10 & Meghalaya & 0.20 & 0.12 & 61 & 0.09 & 45 & 1.05 & 0.30 & 29 & 0.25 & 24 \\
\hline 11 & Mizoram & 0.06 & 0.00 & 7 & 0.00 & 0 & 0.06 & 0.00 & 0 & 0.00 & 0 \\
\hline 12 & Nagaland & 0.17 & 0.01 & 4 & 0.01 & 3 & 0.92 & 0.00 & 0 & 0.00 & 0 \\
\hline 13 & Sikkim & 0.07 & 0.00 & 0 & 000 & 0 & 0.23 & 0.00 & 0 & 0.00 & 0 \\
\hline 14 & Tripura & 0.16 & 0.07 & 43 & 0.05 & 31 & 0.59 & 0.02 & 3 & 0.02 & 3 \\
\hline \multicolumn{12}{|c|}{ Union Territories } \\
\hline 1 & $\begin{array}{l}\text { Andaman \& } \\
\text { Nicobar }\end{array}$ & 0.01 & 0.01 & 81 & 0.00 & 47 & 0.04 & 0.00 & 0 & 0.00 & 0 \\
\hline 2 & $\begin{array}{l}\text { Dadra \& } \\
\text { Nagar Haveli }\end{array}$ & 0.01 & 0.00 & 0 & 0.00 & 0 & 0.06 & 0.00 & 0 & 0.00 & 0 \\
\hline 3 & Puducherry & 0.02 & 0.03 & 100 & 0.01 & 79 & 0.10 & 0.00 & 0 & 0.00 & 0 \\
\hline \multicolumn{2}{|c|}{ Total } & 126.8 & 81.1 & 64 & 28.9 & 23 & 599.1 & 44.7 & 7 & 37.5 & 6 \\
\hline
\end{tabular}




\subsection{Farmers' Feedback on the Design}

The design of SHCs needs to be looked at from the point of view of coverage and intensity of soil testing. Coverage means the scale at which the samples are taken and how representative they are in identifying the variations in soil quality. In the case of intensity, what are the parameters covered while testing the soils? While farmers would benefit more from a comprehensive SHC that is more representative of their plots and covers all the important aspects of soils, it could be time consuming and expensive on the administrative side. More soil indicators mean more sophisticated STLs and better equipment and skilled personnel.

Soil experts and farmers feel that the present scale (2.5 ha grid for irrigated areas and 10 ha grid for the rainfed area) is not representative of all the soil types. Given the high fragmentation in India, each farmer may have a number of fragments, that too not at one place. Farmers want more soil samples to be collected and tested so that they can rely on the recommendations. The number of soil samples per unit area should be based on soil variability. In most of the developed countries, soils are tested as per the requirement by crop.

It has also been observed in the field that the norms prescribed in the SHC scheme are not followed due to various reasons. The timing of soil sampling and the methods of sampling are not adopted in a number of cases. Moreover, the time taken for sample collection and its testing in the lab (although it improved after the SHC scheme) is much longer than usually prescribed. This results in samples losing their characters due to exposure. Hence, the accuracy of the tests and the recommendations prescribed may not be reliable. In some areas, SHCs are not provided to all the farmers. Besides, it has been observed that SHCs are not provided in time. Lack of accuracy, along with the absence of timely provision of recommendations, has affected the credibility of SHCs among farmers. Lack of skilled staff, equipped laboratories, and other infrastructure is the main reason for these shortcomings in the scheme (for details, refer to the appendix on soil health and soil testing and field observations as well as opinion expressed by different stakeholders).

A comparison of indicators included in SHCs in India with other countries such as the USA (across its states) indicates that only nutrient availability, along with some physical soil characters such as $\mathrm{PH}$ and EC, are included in India, while a number of states in USA use many other indicators, such as physical indicators, topography, water, soil indicators, biological indicators and nutrient holding capacity (Table 7). Some of these indicators, such as water quality, soil erosion, slope, crop residue, etc., are very important for proper soil management. Experts feel that soil texture, direction of slope, water quality, irrigation source, cracks on soil surface, depth of the soil and crop residues can be included in the Soil Health Card. However, cost may be an issue, but in the case of some aspects such as the irrigation source, depth of soil etc. could be collected from general observation and through the farmer's knowledge about his farm. The importance of including water test in the SHC can be seen in Fig. 5. 
Fig. 5: Importance of including water test in the SHC

Salt-affected Irrigation Water

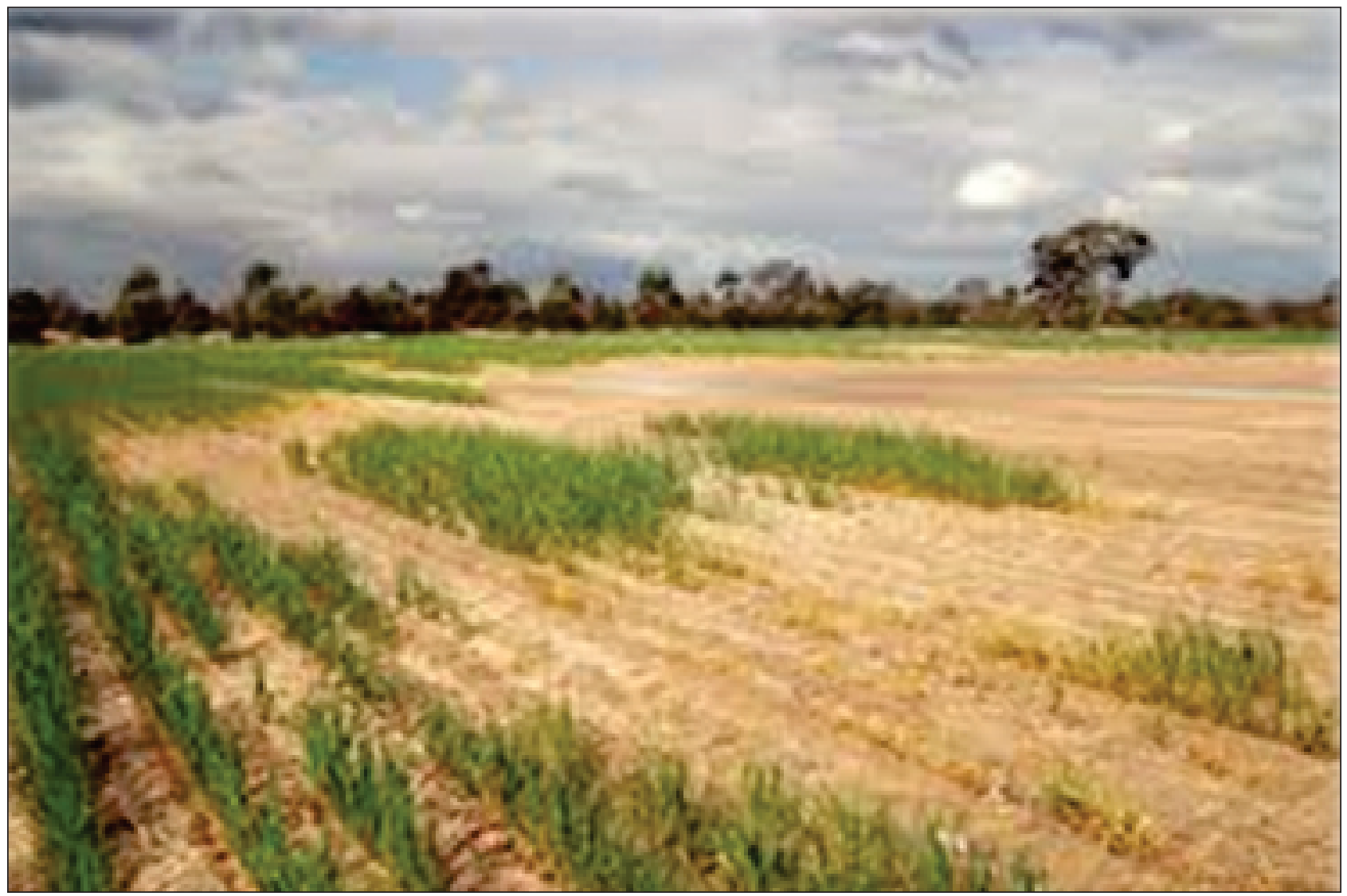

Normal Irrigation Water

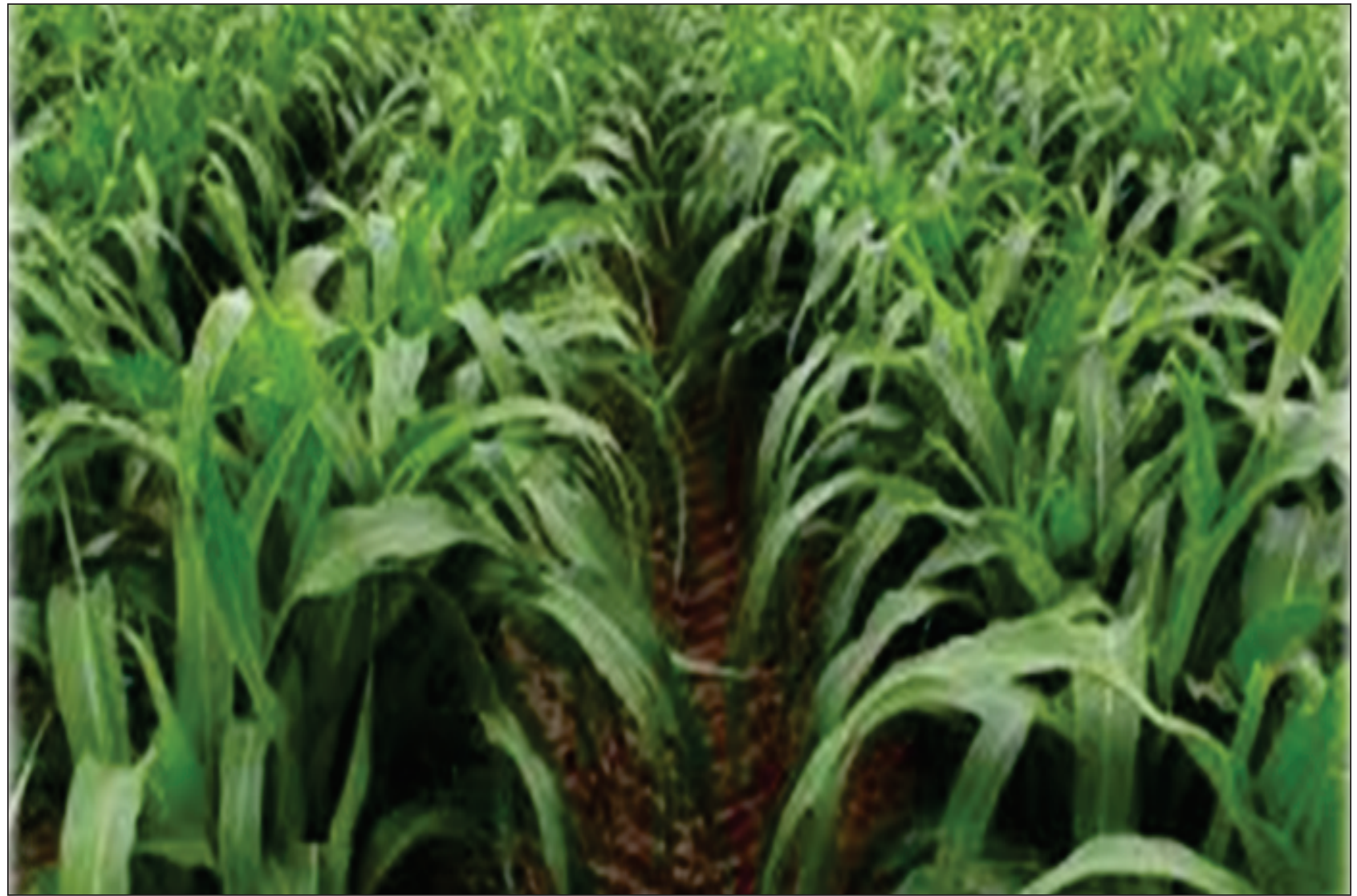


Table 7A: Indicators mentioned in SHCs in different states of USA

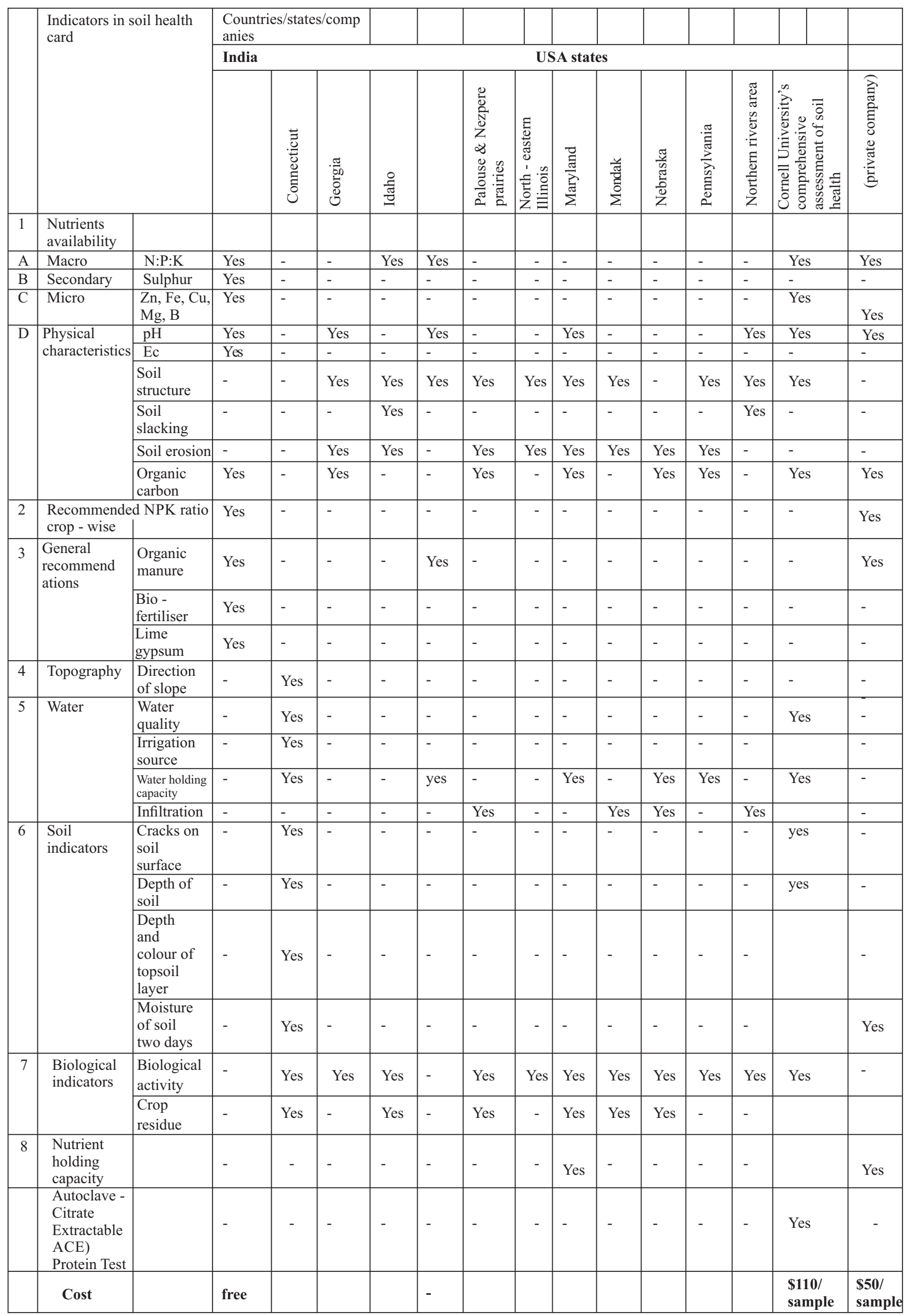


Table 7B: Indicators mentioned in SHCs in other countries

\begin{tabular}{|c|c|c|c|c|c|c|c|c|c|c|c|}
\hline 1 & $\begin{array}{c}\text { Nutrients } \\
\text { Availability }\end{array}$ & & $\begin{array}{l}\text { Yes (only } \\
\text { N) }\end{array}$ & $\begin{array}{l}\text { Yes (only } \\
\mathrm{N} \text { ) }\end{array}$ & $\begin{array}{l}\text { Yes (only } \\
\text { N) }\end{array}$ & $\begin{array}{l}\text { Yes (only } \\
\mathrm{N})\end{array}$ & Yes & Yes & Yes & Yes & Yes \\
\hline A & Macro & $\mathrm{N}: \mathrm{P}: \mathrm{K}$ & - & - & - & - & Yes & - & - & Yes & \\
\hline B & Secondary & Sulphur & Yes & Yes & Yes & Yes & - & - & - & - & \\
\hline \multirow[t]{2}{*}{$\mathrm{C}$} & \multirow[t]{2}{*}{ Micro } & \multirow[t]{2}{*}{$\begin{array}{l}\mathrm{Zn}, \mathrm{Fe}, \mathrm{Cu}, \\
\mathrm{Mg}, \mathrm{B}\end{array}$} & & & & & $\begin{array}{l}\text { Yes (only } \\
\text { B) }\end{array}$ & - & Yes & - & \\
\hline & & & Yes & Yes & Yes & Yes & Yes & Yes & Yes & Yes & Yes \\
\hline \multirow[t]{6}{*}{$\mathrm{D}$} & \multirow{6}{*}{$\begin{array}{c}\text { Physical } \\
\text { characteristics }\end{array}$} & $\mathrm{pH}$ & Yes & Yes & Yes & Yes & Yes & Yes & - & - & Yes \\
\hline & & $\mathrm{Ec}$ & - & - & - & - & - & - & - & Yes & \\
\hline & & Soil structure & - & - & - & - & - & - & - & - & \\
\hline & & Soil slacking & - & - & - & - & - & - & - & Yes & \\
\hline & & Soil erosion & Yes & Yes & Yes & Yes & Yes & Yes & Yes & Yes & Yes \\
\hline & & $\begin{array}{l}\text { Organic } \\
\text { carbon }\end{array}$ & - & & - & - & - & - & - & - & \\
\hline 2 & $\begin{array}{l}\text { Recommended NPK } \\
\text { ratio crop wise }\end{array}$ & & Yes & Yes & Yes & $\begin{array}{c}- \\
\text { Yes }\end{array}$ & $\begin{array}{c}- \\
\text { Yes }\end{array}$ & - & - & $\begin{array}{c}- \\
\text { Yes }\end{array}$ & \\
\hline \multirow[t]{3}{*}{3} & \multirow[t]{3}{*}{$\begin{array}{c}\text { General } \\
\text { recommendations }\end{array}$} & $\begin{array}{l}\text { Organic } \\
\text { manure }\end{array}$ & - & - & - & - & - & - & - & - & \\
\hline & & Bio fertiliser & - & - & - & - & - & - & - & - & \\
\hline & & Lime/gypsum & - & - & - & - & - & - & - & - & \\
\hline 4 & Topography & $\begin{array}{c}\text { Direction of } \\
\text { slope }\end{array}$ & - & - & - & - & - & - & - & - & \\
\hline \multirow[t]{4}{*}{5} & \multirow[t]{4}{*}{ Water } & $\begin{array}{c}\text { Water } \\
\text { quality }\end{array}$ & - & - & - & - & - & - & - & - & \\
\hline & & $\begin{array}{c}\text { Irrigation } \\
\text { source }\end{array}$ & Yes & Yes & Yes & Yes & - & - & - & Yes & \\
\hline & & $\begin{array}{c}\text { Water } \\
\text { holding } \\
\text { capacity }\end{array}$ & & & & & - & - & - & - & \\
\hline & & Infiltration & - & - & - & - & - & - & - & - & \\
\hline \multirow[t]{7}{*}{6} & \multirow[t]{7}{*}{ Soil indicators } & $\begin{array}{c}\text { Cracks on } \\
\text { soil surface }\end{array}$ & - & - & - & - & - & - & - & - & \\
\hline & & Depth of soil & - & - & - & - & - & - & - & - & \\
\hline & & $\begin{array}{c}\text { Depth and } \\
\text { colour of } \\
\text { topsoil layer }\end{array}$ & - & - & - & - & - & - & - & Yes & \\
\hline & & $\begin{array}{c}\text { Moisture of } \\
\text { soil two days } \\
\text { after heavy } \\
\text { rain }\end{array}$ & - & - & - & - & - & - & - & - & \\
\hline & & $\begin{array}{l}\text { How moist } \\
\text { soil particles } \\
\text { hold together }\end{array}$ & - & - & - & - & - & - & - & - & Yes \\
\hline & & $\begin{array}{l}\text { Rooting } \\
\text { system }\end{array}$ & - & - & - & - & - & - & - & - & \\
\hline & & $\begin{array}{c}\text { Soil } \\
\text { respiration } \\
\end{array}$ & yes & yes & yes & yes & - & - & - & Yes & \\
\hline \multirow[t]{2}{*}{7} & \multirow[t]{2}{*}{ Biological indicators } & $\begin{array}{c}\text { Biological } \\
\text { activity }\end{array}$ & - & - & - & - & - & - & - & - & \\
\hline & & Crop residue & - & - & - & - & - & - & Yes & - & \\
\hline \multirow[t]{3}{*}{8} & $\begin{array}{l}\text { Nutrient holding } \\
\text { capacity }\end{array}$ & & - & - & - & - & - & - & - & - & \\
\hline & $\begin{array}{c}\text { Autoclave-Citrate } \\
\text { Extractable (ACE) } \\
\text { Protein Test } \\
\end{array}$ & & & & & & - & - & - & - & \\
\hline & Cost & & & & & & & & & & \\
\hline
\end{tabular}




\subsection{Designs in Different States}

\section{Bhoochetana in Karnataka}

The Government of Karnataka initiated a novel mission with the project 'Bhoochetana' from the year 2009-10 with the mission goal of increasing the average productivity of soil by $20 \%$. The consortium partners of the project are Karnataka State Department of Agriculture, Watershed Development Department, UAS, Bengaluru/Dharwad/Raichur, while ICRISAT Hyderabad is the technical consultant.

Main strategies: Soil-test-based nutrient management with a major emphasis on micro nutrients, distribution of inputs at $50 \%$ subsidy at the cluster village level, services of farmer facilitators for transfer of technology, farmer field schools, wide publicity through wall writings, posters, village meetings and mass media, effective project monitoring, and feedback.

Under Bhoochetana, stratified soil sampling method was used. Districts were divided into three toposequences. In each topo-sequence location, samples were taken proportionately from small, medium, and large farmholding farmers' fields to represent different soil colour, texture, cropping system, and agronomic management.

Soil sampling was not done for all the farmers in the village but was collected from only about $20 \%$ of the farmers, and the soil sample size was based on the soil variability index with a larger number of samples from higher variability index and fewer number from lower variability index to economise on costs without losing relevance of soil test results for farmers. Test procedures were carried out accurately and in a timely manner. In addition, micro nutrients such as $\mathrm{S}, \mathrm{Mg}$, and $\mathrm{B}$ were supplied at $50 \%$ subsidy, if there was deficiency in soils.

Project implementation started during Kharif 2009-10 in six districts, covering 2.25 lakh hectares, 1440 villages, and 2 lakh farmers. The Rabi area coverage during 2009-10 was 0.59 lakh Ha. An enhancement in yields of $33-45 \%$ was observed in the treated areas. The project was extended to 16 districts during 2010-11, covering 12.0 lakh hectares during the Kharif season, including 5,030 villages and 8.50 lakh farmers. The rabi area coverage during 2010-11 was 3.32 lakh Ha. An enhancement in yields of $21-41 \%$ was observed in the treated areas. During Kharif 2011-12, the Bhoochetana programme was implemented in all 30 districts, covering 25.4 lakh hectares in 13,800 villages and 20 lakh farmers. The rabi area coverage during 2011-12 was 5.40 lakh Ha. An enhancement in yields of 29$41 \%$ was observed in the treated areas. The programme was extended to 50 lakh ha of a dryland area and 5 lakh ha of irrigated area during 2012-13. By the fourth year, the project reach was to 26,000 villages covering 42 lakh farmers. There was a considerable area coverage during Rabi season as well, i.e., 27 lakh ha during 2012-13. An enhancement in yields of 11-37\% was observed in the treated areas.

\section{IFPRI Bihar randomised an experiment of the SHC design}

International Food Policy Research Institute (IFPRI) conducted a randomised controlled trial in Bihar to understand the effectiveness of the soil health cards on farmers' incomes on an experimental basis before the SHC scheme of the Government of India. They found no evidence of any impact of soil testing and customized fertiliser recommendations on actual fertiliser use or the willingness to pay for the soil testing services. The study was conducted by the Department of Soil Science of Rajendra Agricultural University (RAU), Bihar, and IFPRI. The three possible explanations for the lack of response are as follows:

a) Farmers simply did not understand the content of the SHC; we should not expect farmers to change their behaviour on the basis of recommendations that they do not understand. 
b) Farmers understood the contents of the SHC but did not find the soil analysis and fertiliser recommendations to be reliable or compelling.

c) Farmers did in fact internalise recommendations, and the information did alter their preferred fertiliser mix, but other factors (such as cost, liquidity, or timely availability of specific fertilisers) prevented them from acting on these preferences by shifting their actual application.

\subsection{Improvements Required in the SHC Scheme Design}

\section{The Scheme}

Soil health card is field-specific detailed report of soil fertility status and other important soil parameters that affect crop productivity. Besides soil health, it provides an advisory on soil-test-based use of fertilisers and amendments. As per the design, soil health assessment of farmer fields will be taken up once in two years and soil health cards will be issued. Districts, blocks, and villages within them will be selected in such a way that an action plan is in place to cover them every two years. The nodal soil test lab shall prepare timelines for scheduling the soil health cards in the district in phases. The year-wise coverage of the number of talukas / blocks can be prepared in such a manner that a continuous soil analysis takes place every two years.

Selection Process: The State Governments will prepare yearly action plans indicating the number of districts to be covered, the number of irrigated holdings and rainfed holdings in the selected districts, the number of soil samples to be drawn from irrigated holdings, the number of samples to be drawn from rainfed holdings, and finally, the total number of samples to be drawn and tested. Soil sample collection should be done during the summer months, when there was no standing crop. In most of the cases, this window was open only in April and May, just for 60 days. Hence, all the sample collection should be completed within these two to three months and the sample test results should reach farmers by July. But, generally it takes six to nine months to issue soil health cards. And one season will be over by the time the test results come in. This needs to be rectified and the soil test results should reach farmers before the onset of monsoons so that they can plan the cropping pattern and fertiliser use.

Agencies: a) Agriculture Department staff; b) Science Colleges and students and soil testing/chemistry laboratory staff; c) State Agricultural Universities and their soil testing staff. Soil testing is to be outsourced to private agencies through tenders wherever feasible (based on the technical and financial bids, price quoted for one sample test). Science colleges could be nominated with a provision of providing equipment. Direct aid for setting up of soil testing laboratories is another option. Many farmers expressed faith in private soil testing laboratories as they maintained quality and timely distribution of test results. But only a few farmers are willing to pay for soil tests. Hence, there was a need for promoting the Public-Private Partnership mode of soil testing labs at different locations. In this, investments may be through private sectors with a subsidy component from the government towards payments for testing (per sample basis). The rate per sample is determined in a competitive bidding process from the technically qualified labs that employ qualified and trained chemists. Though this system is currently working, there is a need for increasing competitiveness among private institutions to maintain quality at a reasonable cost. Farmer Producer Organisations need to be encouraged to participate in the bidding process through special incentives.

Sampling norms: The quality of soil testing results and fertiliser recommendations depend upon soil sampling. The following scientific norms are prescribed for this:

i. In the irrigated areas, samples will be drawn in a grid of $2.5 \mathrm{ha}$. In rainfed areas, sampling will be drawn in a 10 ha grid. 
ii. In irrigated areas, large, medium, and semi-medium holdings will be sampled and tested holding-wise. In case of marginal and small holdings, sampling in a 2.5 ha grid will be followed. However, field observations indicate that only one sample is taken and tested per grid and the same results are printed on SHCs of all grid farmers.

iii. In rainfed areas, all the large holdings will be sampled and tested. In case of medium or semimedium, small and marginal holdings will be sampled and tested in a 10 ha grid. Here too, field observations indicate that only one sample per grid is taken and tested. The sample was collected from 3-4 locations in the grid and pooled for testing.

iv. The ideal time for the collection of soil samples is between sowing/planting of the other crop, i.e., when fields are vacant. This happens mostly in the months of March to June. In many locations, this window was open just for two months, April and May. Often, samples were taken on buds, and only road side plots were covered without following proper sampling framework. However, to meet the target, sample collection should be done in the campaign mode by involving agriculture and allied departments, science collages, and village youth. The agricultural department should monitor the programme closely in order to maintain the quality of samples collected.

v. The sampling depth for field crops should be 0 to $15 \mathrm{~cm}$.

vi. Samples have to be collected preferably with the help of stainless steel tube augur, or with a khurpi / spade or kassi.

vii. A brief training for the soil sampling staff/students/farmers/field extension machinery would be necessary to ensure the collection of representative soil sample and their labelling and transportation to the STLs. Field observations indicated that samples collected were kept idle for months. They need to be properly dried, sieved, packed, and labelled in time to avoid exposure to atmosphere.

viii. GPS coordinates have to be essentially recorded at the time of soil sampling, which will be downloaded in the STL computer. It is also important to adopt a computerised pre-determined grid system with randomised sampling points, as adopted by Punjab's agricultural department. Punjab's agricultural department distributed tablets with a software application, in which predetermined grids were mapped in GPS-enabled software for the identification of grids in the fields and taking random samples within the grid. This will reduce human error in sampling and collection.

ix. The target villages will use stratified sampling techniques. Samples will be collected from marginal, small, and large farms to address variations that arise due to different management practices. Within each farm size class, samples will be chosen to represent all possible soil fertility variations.

x. The focus group discussions and key informant interviews indicated that the uniform grid size does not take into account differences in variation in soil types and cropping pattern. The grid size should be larger if there is less variability in soils and vice versa. This will not only represent soil types based on statistical principles, but it will also reduce costs and workforce. Some studies show that covering $20-30 \%$ of the farmers or 20-30 samples per 500 ha is enough for reasonable soil test values if the sample is collected scientifically.

xi. There is a need for introducing flexible mechanisms for grid sample sizes according to the 
variability in the soil fertility index. In this regard, soil fertility variability maps should be developed for each village. Based on this, the grid size should be reduced in low variability villages and increased in high variability villages. In this way, the collected samples will represent the farmer's actual soil conditions with little sampling error, and work burden on the local staff can be reduced to some extent and representativeness of soil samples can be enhanced, which is crucial for increasing the confidence of farmers in the SHC.

Soil analysis: Soil samples should be processed following standard procedures and analysed for various parameters, namely $\mathrm{pH}$; electrical conductivity (EC); Organic Carbon (OC); and available N, $\mathrm{P}, \mathrm{K}, \mathrm{S}$ and micronutrients ( $\mathrm{Zn}, \mathrm{Cu}, \mathrm{Fe}, \mathrm{Mn} \& \mathrm{~B})$. However, only a few soil testing laboratories had facilities for micro nutrient tests. In some laboratories, instruments are outdated and take a lot of time to analyse just $\mathrm{N}, \mathrm{P}$, and $\mathrm{K}$. There were frequent power cuts, and some were not in a working condition. In some of the laboratories, there was a shortage of chemical reagents to test for basic elements such as NPK. In the recent years, state departments procured mini soil testing kits. In some of the block agricultural offices/labs, five to six mini kits were procured, but agricultural extension officers were too busy with multiple tasks and hardly had any time to test soil samples. It was observed that soil testing through mini kits was time consuming, and the test results were not as accurate as those of full-fledged labs. Hence, in addition to the department soil testing labs, science colleges with soil testing laboratories were involved and assigned the task of soil testing. This was a good decision for timely and accurate dispatch of soil test results to farmers. The students did the work of soil testing under the guidance and supervision of professors. To overcome staff shortage with the state government agricultural department, private agencies were engaged through a competitive bidding process. Field observations indicated that although some private companies maintained quality, some did not. There was a need for proper monitoring and evaluation of the work of private companies. Alternatively, contractual staff can be employed for the testing of soil samples. The soil analysis has to be completed within three weeks of receipt of soil samples in the STL. In the field visits, it was observed that the process of drying, grinding of soil and bottling, etc. was not followed properly by many soil testing labs. There was an inordinate delay in sample testing up to six to nine months. This needed to be rectified to increase the confidence of the farmers in SHC.

There was a significant gap between farmers covered and SHCs distributed. It was observed that awareness camps, campaigns, and Kisan Melas should be the main channel for the distribution of SHCs as that would achieve two goals of handing over the SHCs and explaining how to use SHC simultaneously. It was noted that SHCs were distributed by agricultural officers through democratically elected president or block-level elected representatives in campaigns and through village revenue assistant or by post/online. It was also observed that whenever the SHC was distributed by elected representatives after explaining the content, farmers felt that they understood the utility of the cards and followed recommendations.

Soil Health Card: SHC contains information regarding soil fertility and provides recommendations on fertiliser application for crops and soil amendments required in the case of saline or alkaline soils. Suggestions are made regarding integrated nutrient management. Based on the soil analysis, these are the observations:

i. Fertiliser recommendations will be developed after considering the available infrastructure/financial resources for the small holders.

ii. The critical values for delineating deficiency levels will be tested and doses will be recommended for applications.

iii. Soil-test-based applications for removing deficiencies will be standardised as a component of agronomic practice for the selected crops. 
iv. Timelines will be determined by nutrient status mapping based on soil fertility analysis and productivity enhancement through the application of deficient nutrients. Data will be developed for diagnostic soil analysis and deficient fields in each district. Nutrient recommendations will be prepared separately for Kharif and rabi crops. Block-wise fertiliser dosage adjusted for soil test nutrient status for various crops will be developed.

Cross Checking: Mechanisms are in place for random checking of $1 \%$ of the total samples that will be analysed by external agencies in order to ensure the quality of soil analysis. A team of Deputy Director of Agriculture (Ext.), District Agriculture Officer, Assistant Director of Agriculture (STL), and a Soil Scientist from SAU/ ICAR would jointly monitor, inspect, and evaluate the functioning of STLs / other concerned agencies pertaining to the issue of soil health cards to the respective districts. The joint certificate will be issued by the District Agriculture Officer, Sarpanch, and Gram Sevak regarding satisfactory sample collection work. Also, a list of farmers whose soil sample has been collected will be displayed at the Gram Panchayat Office.

At the district level, a state-of-the-art soil testing lab needs to be developed either by a public or private agency, which will be accredited by an international agency. This lab should act as referral lab and develop block-wise soil fertility maps to determine the grid size in each block.

\subsection{Socio-economic Characteristics of the Sample Farmers}

The basic socio-economic background of the sample farmers is given in Table 8. Overall, the share of small and marginal farmers is $38.2 \%$ and SC/ST farmers is $22.1 \%$. The region-wise differences in the share of small and marginal framers is given in the table.

Table 8: Basic Features of the Sample Households (HH)

\begin{tabular}{|l|c|c|c|c|c|c|}
\hline \multirow{2}{*}{$\begin{array}{l}\text { Region / } \\
\text { State }\end{array}$} & $\begin{array}{l}\text { Sample } \\
\text { Size (no.) }\end{array}$ & $\begin{array}{l}\text { Coverage of } \\
\text { social groups } \\
\text { (\% SC/ST) }\end{array}$ & \multicolumn{2}{|c|}{ Coverage of Economic Groups } & $\begin{array}{l}\text { Average } \\
\text { Farm Size } \\
\text { (acres) }\end{array}$ \\
\cline { 5 - 7 } & & & \% of S\&MF & $\begin{array}{l}\text { \% of } \\
\text { Medium } \\
\text { Farmers }\end{array}$ & $\begin{array}{l}\text { \% of } \\
\text { Large } \\
\text { Farmers }\end{array}$ & \\
\hline Central & 320 & 12.7 & 20.9 & 43.9 & 35.2 & 7.5 \\
\hline East & 240 & 51.4 & 78.7 & 21.3 & 0.0 & 1.7 \\
\hline North East & 448 & 55.4 & 47.0 & 51.0 & 2.0 & 3.1 \\
\hline North & 864 & 15.1 & 25.9 & 27.1 & 47.0 & 8.3 \\
\hline South & 800 & 12.7 & 28.1 & 56.7 & 15.2 & 4.7 \\
\hline West & 512 & 8.0 & 51.0 & 42.5 & 6.5 & 3.0 \\
\hline Total & 3184 & 22.1 & 38.2 & 41.3 & 20.4 & 5.1 \\
\hline
\end{tabular}

Note: $\mathrm{S} \& M F=$ Small and Marginal farmers $(<2.5$ acres $)$; Medium Farmers= 2.5 to 7.5 Acres; Large Farmers $=>7.5$ acres

Table 9: Basic Features of the Sample Households (HH) by irrigation status

\begin{tabular}{|l|c|c|c|c|c|}
\hline \multirow{2}{*}{$\begin{array}{l}\text { \% irrigated } \\
\text { group }\end{array}$} & \multirow{2}{*}{$\begin{array}{l}\text { Coverage of } \\
\text { social groups } \\
\text { (\% SC/ST) }\end{array}$} & \multicolumn{3}{|c|}{ Coverage of Economic Groups } & \multirow{2}{*}{$\begin{array}{l}\text { Average } \\
\text { Farm Size } \\
\text { (acres) }\end{array}$} \\
\cline { 3 - 5 } & & \% of S\&MF & $\begin{array}{l}\text { \% of } \\
\text { Medium } \\
\text { Farmers }\end{array}$ & $\begin{array}{l}\text { \% of Large } \\
\text { Farmers }\end{array}$ & \\
\hline Less irrigated & 27.0 & 26.8 & 58.5 & 28.0 & 4.6 \\
\hline Medium irrigated & 54.4 & 14.0 & 66.7 & 18.7 & 4.8 \\
\hline Mostly irrigated & 17.9 & 56.8 & 34.4 & 42.8 & 6.0 \\
\hline All & 22.1 & 49.0 & 41.3 & 38.2 & 5.1 \\
\hline
\end{tabular}

Note: Less irrigated (less than $50 \%$ of the total area irrigated); medium irrigated (50 to $80 \%$ ); mostly irrigated (more than $80 \%$ of total area is irrigated) 
The study grouped farmers based on the share of irrigated area in the total area (Table 9). Farmers who possess less than $50 \%$ of area under irrigation were classified as "less irrigated", farmers with $50 \%$ to $80 \%$ irrigated area were classified as "medium irrigated", and farmers with more than $80 \%$ irrigated area were classified as "mostly irrigated". The average area of farmers was higher in "mostly irrigated" than "less irrigated" and "medium irrigated" group of farmers. Table 9 shows that among SC/ST farmers, about $27.0 \%$ had irrigation facilities for less than $50 \%$ of their total cultivated area, about $54.4 \%$ of the farmers had irrigated area between $50 \%$ and $80 \%$ of their total land, and the remaining $17.9 \%$ farmers had land with more than $80 \%$ irrigated. The percentage of irrigated area was higher among small and marginal farmers compared to other farmers.

\subsection{Awareness, Utilisation, and Outputs under the SHC Scheme}

Farm-level impacts are assessed in terms of awareness, participation in the activities, fertiliser use, and impact on crop yields, cost reduction, and profitability. Analysis is carried out across farm size classes and social groups. The analysis is presented by region (zone), development, and time of card issued (old, recent, new, etc).

\section{Awareness}

Awareness levels are quite good in South, West, Central, and Eastern zones, with about $80 \%$ to $90 \%$ awareness. North-East has the lowest awareness at 31.8\%, followed by North (78.4\%). At the national level, $82.2 \%$ of the sample farmers are aware of SHC (Table 10). The high awareness in some zones could be attributed to the proactive nature of the state governments in the soil health card initiative. Very poor awareness in the North-East may be due to prolonged attachment to traditional ways of farming and less use of fertilisers. It should also be noted that organic farming is practiced on a large scale here. So, the priority for SHC appears to be low at the official as well as farmer level.

Table 10: Zone-wise awareness about SHC

\begin{tabular}{|l|c|c|c|c|}
\hline \multirow{2}{*}{ Region/State } & \multicolumn{4}{|c|}{ \% of Sample Farmers } \\
\cline { 2 - 5 } & $\begin{array}{l}\text { Awareness } \\
\text { about SHC }\end{array}$ & Discussion of results & $\begin{array}{l}\text { Awareness } \\
\text { about portal }\end{array}$ & Portal info useful \\
\hline Central & 84.9 & 71.5 & 47.1 & 35.1 \\
\hline East & 84.4 & 70.2 & 33.6 & 24.2 \\
\hline North-East & 31.8 & 10.9 & 3.5 & 2.1 \\
\hline North & 78.4 & 30.4 & 4.5 & 1.2 \\
\hline South & 89.8 & 72.8 & 33.4 & 23.1 \\
\hline West & 88.5 & 69.4 & 15.2 & 12.2 \\
\hline All & 82.1 & 58.6 & 18.1 & 16.8 \\
\hline
\end{tabular}

Across the size classes (Table 11), variations in awareness are not much, though higher proportion of medium and large farmers are aware that the SHC is higher among large farmers, reflecting their better access to officials and other community members. Interestingly, awareness about the SHC portal is higher among small and marginal farmers, and it may be the reason that these farmers don't get cards directly from the extension workers and depend on the portal for printing their cards instead. Cards were issued to large farmers at their doorsteps or through campaigns. 
Table 11: Farm size class-wise awareness about SHC

\begin{tabular}{|c|c|c|c|c|}
\hline \multirow{2}{*}{$\begin{array}{l}\text { Farm size } \\
\text { category }\end{array}$} & \multicolumn{4}{|c|}{$\%$ of Sample Farmers are / saying } \\
\hline & $\begin{array}{c}\text { Awareness about } \\
\text { SHC }\end{array}$ & $\begin{array}{l}\text { Discussion of } \\
\text { results }\end{array}$ & $\begin{array}{l}\text { Awareness } \\
\text { about portal }\end{array}$ & $\begin{array}{l}\text { Portal info } \\
\text { useful }\end{array}$ \\
\hline Small \& Marginal & 79.4 & 57.3 & 21.6 & 21.4 \\
\hline Medium & 81.1 & 61.5 & 12.6 & 11.1 \\
\hline Large & 89.1 & 54.9 & 21.1 & 19.8 \\
\hline All & 82.1 & 58.6 & 18.1 & 16.8 \\
\hline
\end{tabular}

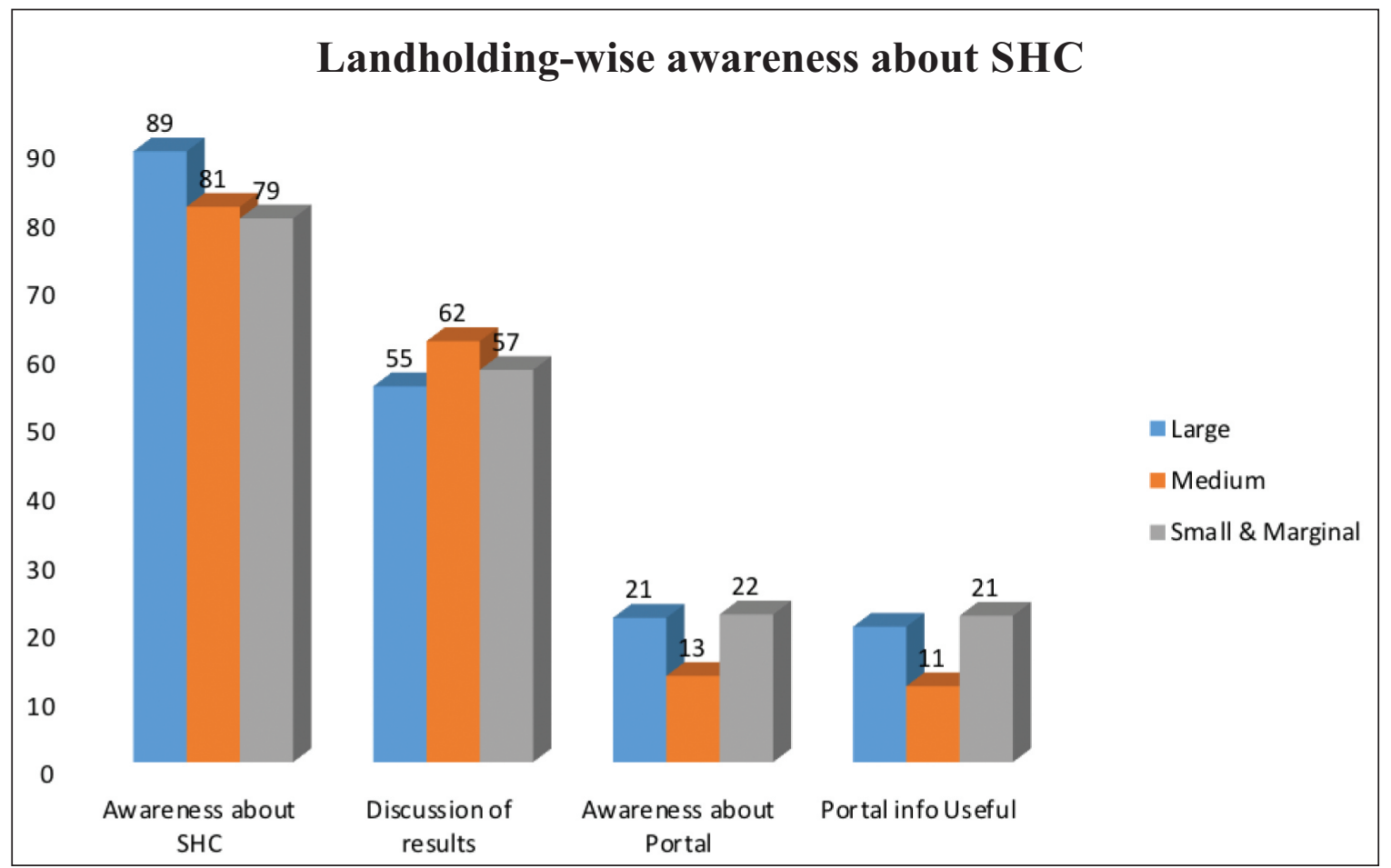

Fig. 6: Landholding-wise awareness about SHC

The social class-wise analysis indicates that Other Backward Caste $(\mathrm{OBC})$ farmers are more aware of SHC (Table 12). This could be due to the reason that they own poor quality lands when compared to FC farmers. Moreover, of late, these communities are showing more interest in and attachment towards farming (Reddy, 2016).

Table 12: Social group-wise awareness about SHC

\begin{tabular}{|l|c|c|c|c|}
\hline \multirow{2}{*}{ Region / State } & \multicolumn{4}{|c|}{ \% of Sample Farmers are / saying } \\
\cline { 2 - 5 } & $\begin{array}{c}\text { Awareness about } \\
\text { SHC }\end{array}$ & $\begin{array}{c}\text { Discussion of } \\
\text { results }\end{array}$ & $\begin{array}{c}\text { Awareness } \\
\text { about portal }\end{array}$ & $\begin{array}{c}\text { Portal info } \\
\text { useful }\end{array}$ \\
\hline \multirow{2}{*}{ FCs } & 80.5 & 56.6 & 15.7 & 14.0 \\
\hline BCs & 95.2 & 73.6 & 19.5 & 19.2 \\
\hline SC/ STs & 67.4 & 41.9 & 19.8 & 19.4 \\
\hline All & 82.1 & 58.6 & 18.1 & 16.8 \\
\hline
\end{tabular}



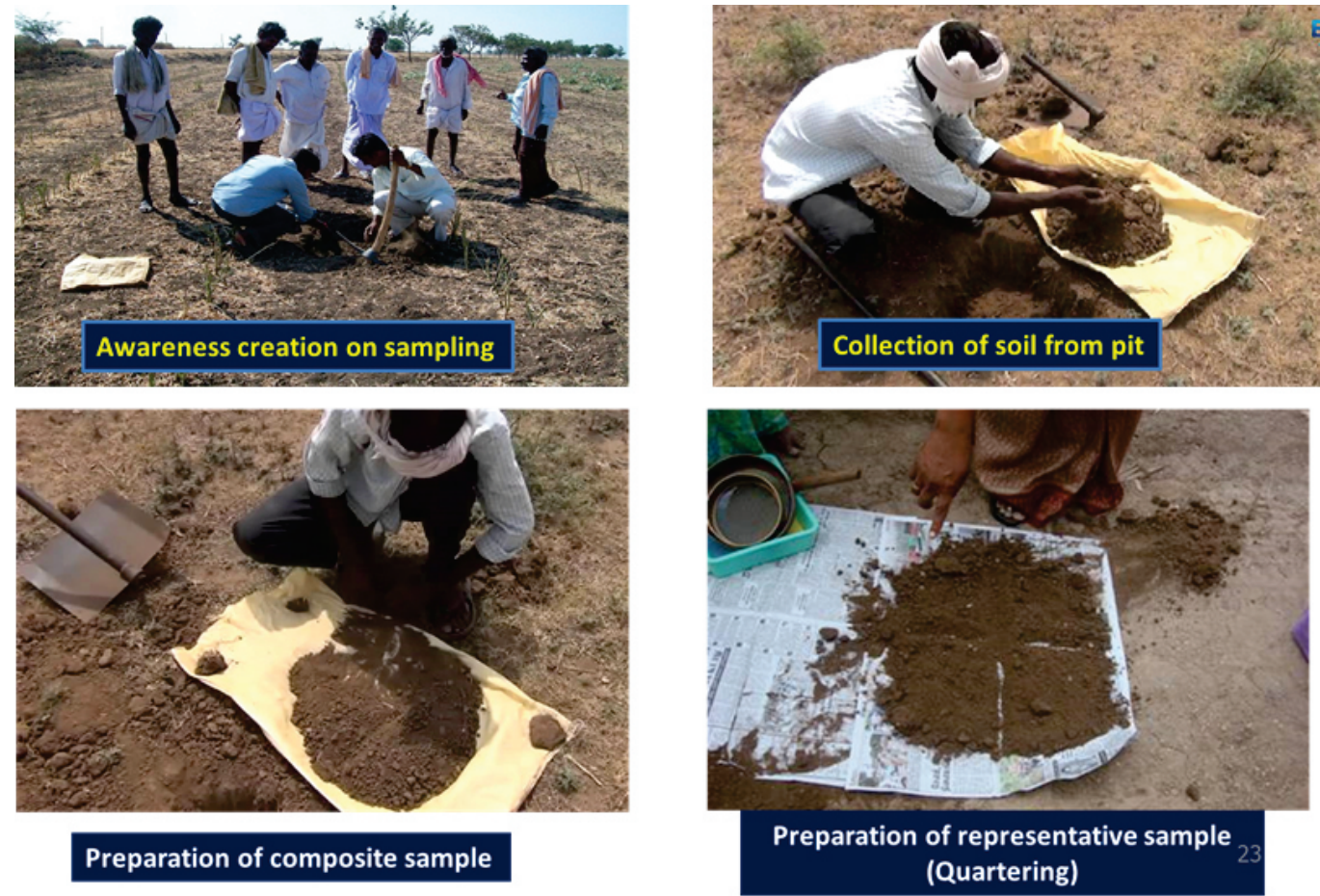

Preparation of composite sample (Quartering)

Fig. 7: Method of Soil Sample Collection

Table 13: Awareness about SHC in developed and less developed states

\begin{tabular}{|l|c|c|c|c|}
\hline \multirow{2}{*}{ State Group } & \multicolumn{4}{|c|}{ \% of Sample Farmers are / saying } \\
\cline { 2 - 5 } & $\begin{array}{c}\text { Awareness about } \\
\text { SHC }\end{array}$ & $\begin{array}{c}\text { Discussion of } \\
\text { results }\end{array}$ & $\begin{array}{c}\text { Awareness } \\
\text { about portal }\end{array}$ & $\begin{array}{c}\text { Portal info } \\
\text { useful }\end{array}$ \\
\hline Developed & 92.4 & 74.2 & 24.2 & 22.9 \\
\hline Less Developed & 55.1 & 17.2 & 0.8 & 0.7 \\
\hline All & 82.1 & 58.6 & 18.1 & 16.8 \\
\hline
\end{tabular}

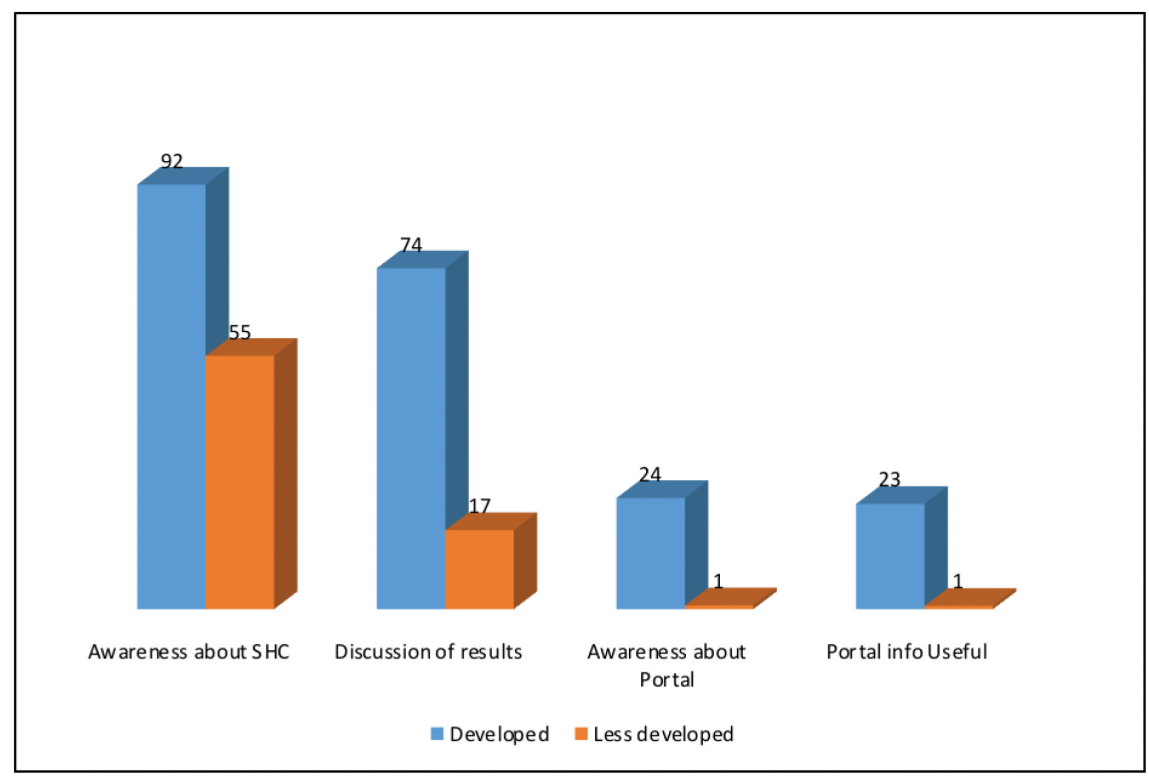

Fig. 8: Awareness about the SHC scheme 
The most significant difference in awareness was between developed and less developed states (Table 13) rather than zone-wise. $92.4 \%$ of the farmers in developed states are aware about SHC compared to only $55.1 \%$ of farmers in less developed states. Awareness about the SHC portal was about $22.9 \%$ among developed state farmers, compared to negligible farmers $(0.7 \%)$ in case of less developed states.

Table 14. Awareness about SHC by irrigation status of the farmers

\begin{tabular}{|l|c|c|c|c|}
\hline \multirow{2}{*}{ \% Irrigated Group } & \multicolumn{4}{|c|}{ \% of Sample Farmers / saying yes } \\
\cline { 2 - 5 } & $\begin{array}{c}\text { Awareness about } \\
\text { SHC }\end{array}$ & $\begin{array}{c}\text { Discussion of } \\
\text { results }\end{array}$ & $\begin{array}{c}\text { Awareness } \\
\text { about portal }\end{array}$ & $\begin{array}{c}\text { Portal info } \\
\text { useful }\end{array}$ \\
\hline Less Irrigated & 84.6 & 59.1 & 4.5 & 3.4 \\
\hline Medium Irrigated & 76.1 & 49.2 & 5.8 & 4.2 \\
\hline Mostly Irrigated & 80.1 & 57.4 & 23.7 & 22.4 \\
\hline All & 82.1 & 58.6 & 18.1 & 16.8 \\
\hline
\end{tabular}

Awareness about SHC was high among "less irrigated" farmers (84.6\%), but awareness about the SHC portal and the usefulness of the portal was higher among "mostly irrigated" farmers (22.4\%). Again, discussion about the results was higher among "less irrigated" farmers (Table 14).

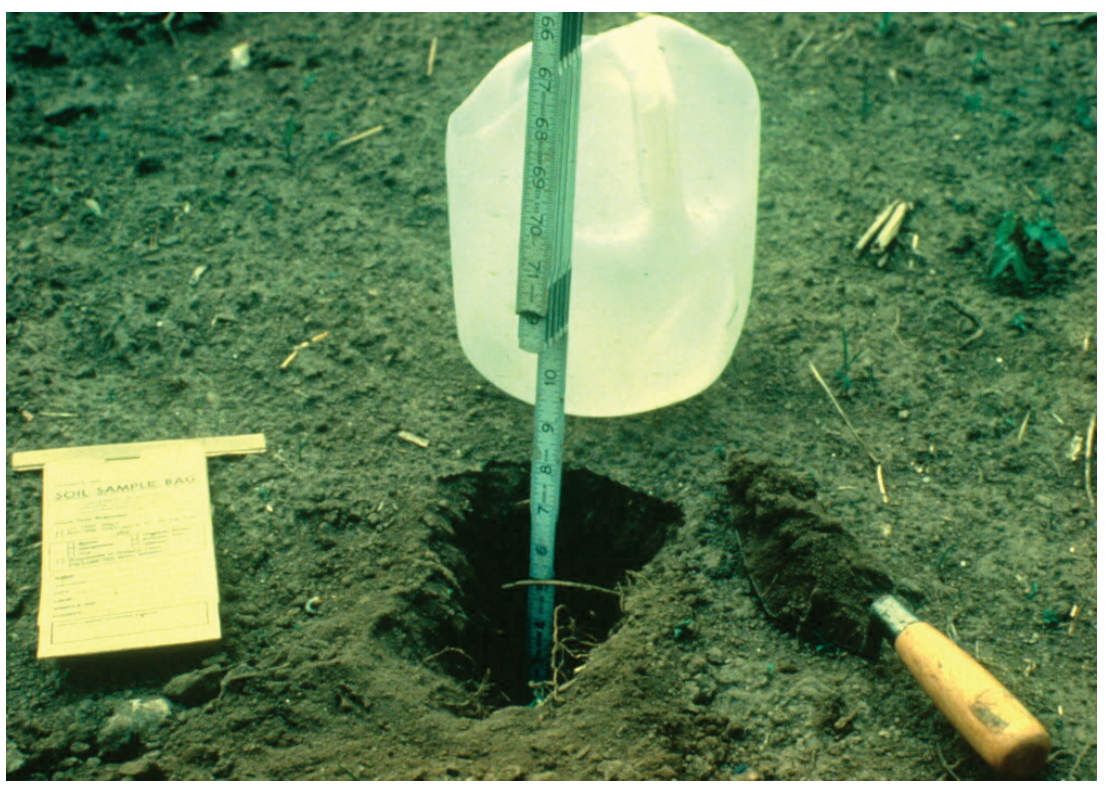

Fig 9: Soil sampling equipment

\section{- Participation}

Overall, it was observed that $36.3 \%$ of the sample farmers participate in meetings, $25.9 \%$ of the farmers participate in exposure visits, and $26.3 \%$ of the farmers participate in the trainings conducted by agricultural officers. About $25 \%$ and $22 \%$ of the farmers said that they have benefited from the trainings and exposure visits, respectively. The participation of farmers from the Central and Eastern zones in SHC activities is the highest, whereas North-East and the Northern region were less than $10 \%$ (Table $15)$. 
Table 15: Participation of farmers in SHC activities across regions

\begin{tabular}{|c|c|c|c|c|c|c|}
\hline \multirow{2}{*}{ Region/State } & \multicolumn{3}{|c|}{$\%$ of Sample Farmers Participating in } & \multicolumn{3}{|c|}{$\%$ of Farmers Benefiting from } \\
\hline & Meetings & $\begin{array}{c}\text { Exposure } \\
\text { visits }\end{array}$ & Trainings & Meetings & Exposure visits & Trainings \\
\hline Central & 65.9 & 63.4 & 67.5 & 63.4 & 61.7 & 61.5 \\
\hline East & 63.9 & 62.0 & 75.5 & 61.2 & 57.3 & 70.5 \\
\hline North-East & 10.3 & 9.4 & 5.1 & 5.8 & 2.8 & 2.0 \\
\hline North & 16.3 & 10.2 & 5.6 & 5.0 & 3.4 & 5.1 \\
\hline South & 51.5 & 27.6 & 27.5 & 47.8 & 26.4 & 26.7 \\
\hline West & 35.1 & 13.4 & 3.7 & 29.9 & 6.2 & 0.7 \\
\hline All & 36.3 & 25.9 & 26.3 & 33.6 & 21.8 & 24.8 \\
\hline
\end{tabular}

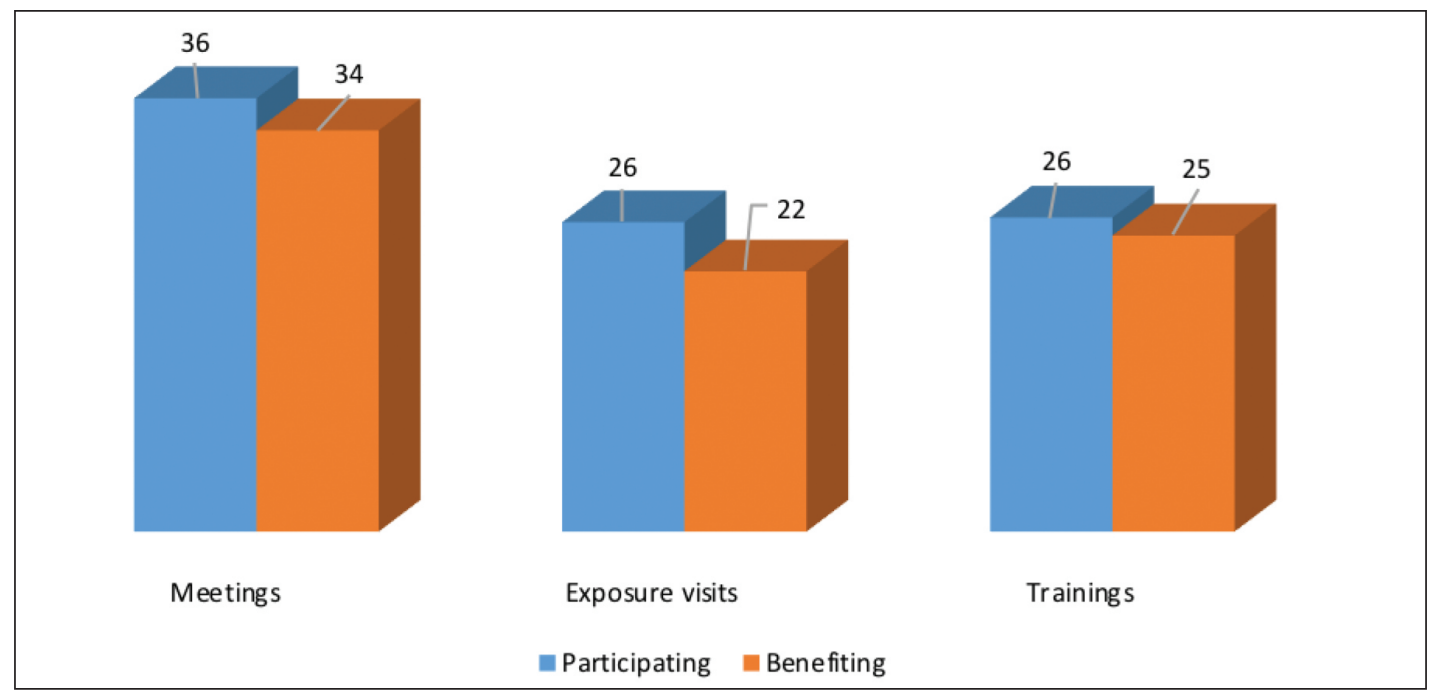

Fig 10 : Percentage of Farmers in SHC Activities and Perception

Table 16: Participation of farmers in SHC activities across states

\begin{tabular}{|c|c|c|c|c|c|c|}
\hline \multirow{2}{*}{ State Group } & \multicolumn{3}{|c|}{ \% of Sample Farmers Participating in } & \multicolumn{3}{c|}{ \% of Farmers Benefitting from } \\
\cline { 2 - 8 } & Meetings & Exposure visits & Trainings & Meetings & Exposure visits & Trainings \\
\hline Developed & 46.3 & 33.4 & 32.6 & 43.6 & 29.4 & 31.1 \\
\hline Less developed & 9.7 & 6.1 & 9.8 & 7.1 & 1.8 & 8.2 \\
\hline All & 36.3 & 25.9 & 26.3 & 33.6 & 21.8 & 24.8 \\
\hline
\end{tabular}

As in the case of awareness, participation in different meetings, exposure visits, and trainings is also significantly higher in developed states (46.3\%) compared to less-developed states $(9.7 \%)$ (Table 16$)$. Significant differences exist even in the percentage of farmers benefiting from exposure visits and trainings.

Although there was no significant difference in the participation of different size class farmers, generally, participation by small and marginal farmers is higher among all the size classes (Table 17). It is interesting to see that small and marginal farmers are more interested and get benefits from government training programmes and exposure visits. Large farmers' participation may be less due to other sources of information. 
Table 17: Participation of farmers in SHC activities across size classes

\begin{tabular}{|c|c|c|c|c|c|c|}
\hline \multirow{2}{*}{ Region / State } & \multicolumn{3}{|c|}{ \% of Sample Farmers Participating in } & \multicolumn{3}{c|}{ \% of Farmers Benefitting from } \\
\cline { 2 - 7 } & Meetings & Exposure visits & Trainings & Meetings & Exposure visits & Trainings \\
\hline Large & 33.4 & 26.1 & 26.9 & 30.9 & 25.7 & 26.6 \\
\hline Medium & 38.7 & 23.4 & 23.2 & 35.6 & 19.8 & 21.9 \\
\hline Small \& Marginal & 35.1 & 28.4 & 29.4 & 32.9 & 22.0 & 27.0 \\
\hline All & 36.3 & 25.9 & 26.3 & 33.6 & 21.8 & 24.8 \\
\hline
\end{tabular}

Participation of farmers from the OBC group is the highest across all activities (Table 18). On the other hand, the percentage of farmers benefiting from these activities was the highest among SC/ST farmers. As far as participation and related benefits are concerned, lower socioeconomic groups (both small and marginal farmers and ST/SC farmers) benefit more when compared to others.

Table 18: Participation of farmers in SHC activities across social groups

\begin{tabular}{|l|l|l|l|l|l|l|}
\hline \multirow{2}{*}{ Social Group } & \multicolumn{2}{|l|}{$\%$} & \multicolumn{2}{l|}{ \% of Farmers Benefiting from } \\
\cline { 2 - 6 } & Meetings & Exposure visits & Trainings & Meetings & Exposure visits & Trainings \\
FCs & 30.1 & 21.9 & 19.9 & 28.7 & 17.1 & 29.0 \\
\hline OBCs & 50.3 & 32.4 & 34.1 & 46.0 & 22.1 & 33.5 \\
\hline SC/STs & 29.9 & 25.2 & 29.3 & 26.6 & 21.8 & 24.1 \\
\hline All & 36.3 & 25.9 & 26.3 & 33.6 & \\
\hline
\end{tabular}

Again, Table 19 indicates that the less irrigated farmers participate more in meetings, while most irrigated farmers participate in exposure visits and trainings when compared to less and medium irrigated farmers. In the case of benefits, a high proportion of most irrigated category farmers get the most in all the three activities. This is in line with our overall observations that the small and marginal farmers and resource-poor farmers are trying to participate in more promotional government programmes, though the benefits are skewed in favour of the resource-rich within the groups. The reason is that their livelihoods are mostly dependent on agriculture compared to large farmers, who can also get income from other sources.

Table 19: Participation of farmers in SHC activities across irrigated area groups

\begin{tabular}{|l|l|l|l|l|l|c|}
\hline \multirow{2}{*}{$\begin{array}{l}\text { Irrigated of } \\
\text { Lroup }\end{array}$} & \multicolumn{2}{|c|}{ \% of Sample Farmers Participating in } & \multicolumn{2}{c|}{ \% of Farmers Benefiting from } \\
\cline { 2 - 7 } & Meetings & $\begin{array}{l}\text { Exposure } \\
\text { visits }\end{array}$ & Trainings & Meetings & $\begin{array}{c}\text { Exposure } \\
\text { visits }\end{array}$ & Trainings \\
\hline Less irrigated & 38.0 & 21.4 & 20.9 & 33.8 & 20.5 & 20.3 \\
\hline Medium irrigated & 26.9 & 21.6 & 21.1 & 25.7 & 14.0 & 17.0 \\
\hline Mostly irrigated & 36.6 & 27.5 & 28.3 & 34.2 & 22.9 & 26.7 \\
\hline All & 36.3 & 25.9 & 26.3 & 33.6 & 21.8 & 24.8 \\
\hline
\end{tabular}




\subsection{Farmers' Perception and Source of Information about SHC}

Overall, $57 \%$ of the sample farmers understand the SHC information. Farmers opine that easy language and colours (green for sufficiency; yellow/brown for deficit; red for severely deficit) should be used to indicate the necessary information to the farmers (Table 20). About $62.8 \%$ of the farmers use fertilisers according to the recommendations made by the SHC. This should be improved by imparting awareness about the need for soil management. 38.7\% of the sample farmers received assistance from local agricultural extension staff regarding the adoption of recommendations as per the SHC. About $73.1 \%$ of the sample farmers said that recommendations are suitable for all plots of the land. About $78 \%$ of the sample farmers indicated that the samples represent all the soil types. However, it should be noted that the sample is slightly based towards better performing districts within states. Proper sampling methods need to be used to increase coverage and relevance of the soil samples collected and tested among all plots. About $68 \%$ of the sample farmers said that the results are provided in time, indicating $32 \%$ of the sample farmers did not get SHC in time. It seems that there was a delay in sample testing and disbursal of SHCs after sample collection. Agricultural officers should take care that the SHC should reach the farmers in time. It is recommended that the SHCs be distributed during the campaigns and kisan melas through elected representatives in the presence of local agricultural officers. Agricultural officers should display and demonstrate the utility of the content of SHC and show how to adopt the recommended doses of fertilisers as per the SHC.

About $60 \%$ of the sample farmers reported that agricultural officers/agricultural extension officers explained the content of the SHC. About $67 \%$ of the sample farmers found the recommendations practical. $46 \%$ of sample farmers reported difficulties in adopting practices. Most of the reasons cited are (i) costly to purchase fertilisers, (ii) non-availability of micro nutrients, (iii) perception that traditional high doses of fertilisers will provide more yields than the recommended lower doses, (iv) little difference in existing practice and SHC recommended practice, (v) there was little reduction in fertiliser doses for small farmers and farmers generally prefer more fertilisers as a result, and (vi) agricultural officers are too busy to give proper advice. Agricultural officers are an important link between the farmers and the information they need. At the block level, agricultural officers are burdened with multiple activities. Information dissemination and soil extension has become a low priority compared to distribution of seed and financial assistance under different government programmes. There is a need for pro-active PPP models, under which rural educated youth and entrepreneurs can actively participate in soil sample collection, testing, and dissemination of SHCs for wider adoption of recommended practices by the farmers.

Table 20: Farmers' perception about SHC across regions

\begin{tabular}{|c|c|c|c|c|c|c|c|c|c|}
\hline \multirow[t]{2}{*}{ Region } & \multicolumn{9}{|c|}{$\%$ of sample farmers saying yes } \\
\hline & 1 & 2 & 3 & 4 & 5 & 6 & 7 & 8 & 9 \\
\hline Central & 79.0 & 77.2 & 50.4 & 80.4 & 85.51 & 82.6 & 88.4 & 77.5 & 52.2 \\
\hline East & 84.4 & 83.6 & 30.5 & 89.1 & 92.97 & 89.8 & 82.0 & 83.2 & 50.8 \\
\hline North - East & 32.3 & 21.0 & 14.9 & 57.6 & 76.52 & 80.3 & 20.2 & 39.9 & 59.6 \\
\hline North & 49.0 & 63.1 & 0.8 & 71.3 & 78.90 & 39.0 & 58.8 & 63.5 & 36.5 \\
\hline South & 71.0 & 68.3 & 51.2 & 73.1 & 77.21 & 76.7 & 78.1 & 76.4 & 31.9 \\
\hline West & 75.6 & 90.0 & 96.3 & 90.3 & 92.54 & 81.5 & 91.0 & 77.6 & 73.6 \\
\hline All & 62.8 & 65.7 & 38.7 & 75.3 & 82.34 & 71.2 & 68.2 & 68.8 & 47.8 \\
\hline
\end{tabular}

1= Understanding; $2=$ Using fertilisers and micronutrients according to SHC; $3=$ Received financial assistance from govt.; $4=$ Recommendations suitable to all plots; $5=$ Do samples represent all the soil types; $6=$ Results provided in time; $7=$ Do extension worker explain content; $8=$ Recommendations practical; $9=$ Difficulties in adopting practices. 
Table 21: Farmers' perception about SHC across size classes

\begin{tabular}{|c|c|c|c|c|c|c|c|c|c|}
\hline \multirow{2}{*}{ Size class } & \multicolumn{9}{|c|}{$\%$ of sample farmers saying yes } \\
\hline & 1 & 2 & 3 & 4 & 5 & 6 & 7 & 8 & 9 \\
\hline Large & 78.7 & 78.3 & 27.6 & 81.0 & 87.6 & 78.5 & 84.0 & 76.6 & 42.7 \\
\hline Medium & 55.8 & 56.9 & 42.8 & 67.7 & 72.5 & 66.4 & 61.8 & 58.7 & 46.0 \\
\hline Small \& Marginal & 61.9 & 68.4 & 40.3 & 80.6 & 90.2 & 72.4 & 66.7 & 75.4 & 52.5 \\
\hline All & 62.8 & 65.7 & 38.7 & 75.3 & 82.3 & 71.2 & 68.2 & 68.8 & 47.8 \\
\hline
\end{tabular}

$1=$ Understanding; $2=$ Using fertilisers and micronutrients according to SHC; $3=$ Received financial assistance from govt.; $4=$ Recommendations suitable to all plots; $5=$ Do samples represent all the soil types; $6=$ Results provided in time; $7=$ Do extension worker explain content; $8=$ Recommendations practical; $9=$ Difficulties in adopting practices.

Zone-wise farmers' opinion about the implementation of the SHC scheme was shown in Table 20. Overall, the perception index was higher in Eastern India, Western India, and Southern India. It was low in North and North-Eastern India. Hence, there was a need for more intensive efforts in North and North-Eastern zones. In many indicators of adoption of the SHC scheme, small and marginal farmers seem to be better compared to large farmers (Table 21). Farmers in more developed states and districts had better knowledge about the soil health card, and they practised recommended practices (Table 22). In the developed states, farmers face fewer difficulties in adopting recommended practices.

\section{Methods for evaluating soil nutrient status}

- Determination of available nutrients by extraction solution

- Determination of exchangeable cations

- Soil test correlations with crop response to the applied fertilizer

- Rapid soil tests
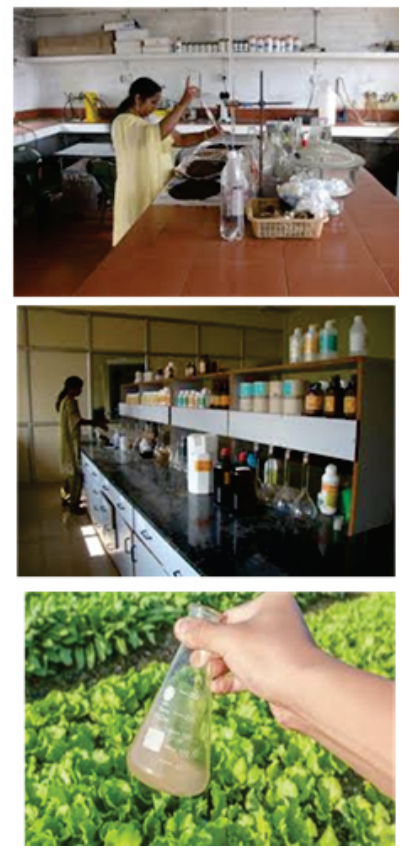

Fig. 11: Methods for Evaluating Soil Nutrient Status 
Table 22: Farmers opinion about SHC in developed and less developed states

\begin{tabular}{|c|c|c|c|c|c|c|c|c|c|}
\hline \multirow[t]{2}{*}{ State Group } & \multicolumn{9}{|c|}{$\%$ of sample farmers saying yes } \\
\hline & 1 & 2 & 3 & 4 & 5 & 6 & 7 & 8 & 9 \\
\hline Developed & 74.8 & 76.2 & 49.8 & 80.3 & 84.8 & 77.5 & 83.6 & 76.3 & 47.0 \\
\hline Less developed & 31.1 & 37.9 & 9.3 & 62.2 & 76.0 & 54.3 & 27.4 & 48.9 & 49.9 \\
\hline All & 62.8 & 65.7 & 38.7 & 75.3 & 82.3 & 71.2 & 68.2 & 68.8 & 47.8 \\
\hline
\end{tabular}

1= Understanding; $2=$ Using fertilisers and micronutrients according to SHC; $3=$ Financial assistance from govt.; $4=$ Recommendations suitable to all plots; $5=$ Do samples represent all the soil types; $6=$ Results provided in time; $7=$ Do extension worker explain content; $8=$ Recommendations practical; $9=$ Difficulties in adopting practices.

Table 23: Farmers' opinion about SHC across Irrigation Categories

\begin{tabular}{|l|l|l|l|l|l|l|l|l|l|}
\hline \multirow{2}{*}{ \% irrigated group } & \multicolumn{10}{|c|}{ \% of sample farmers saying yes } \\
\cline { 2 - 11 } & 1 & 2 & 3 & 4 & 5 & 6 & 7 & 8 & 9 \\
\hline Less irrigated & 57.9 & 57.4 & 47.7 & 76.4 & 88.6 & 70.8 & 76.3 & 66.0 & 45.4 \\
\hline Medium irrigated & 49.7 & 37.4 & 15.2 & 66.7 & 76.6 & 78.4 & 41.5 & 54.4 & 54.4 \\
\hline Mostly irrigated & 65.4 & 70.5 & 38.4 & 75.8 & 81.1 & 70.6 & 68.4 & 70.8 & 47.9 \\
\hline All & 62.8 & 65.7 & 38.7 & 75.3 & 82.3 & 71.2 & 68.2 & 68.8 & 47.8 \\
\hline
\end{tabular}

1= Understanding; $2=$ Using fertilisers and micronutrients according to SHC; $3=$ Received financial assistance from govt.; $4=$ Recommendations suitable to all plots; $5=$ Do samples represent all the soil types; $6=$ Results provided in time; $7=$ Do extension workers explain content; $8=$ Recommendations practical; $9=$ Difficulties in adopting practices.

Table 23 reveals that a higher percentage of the "less irrigated" farmers opine that they understand the SHC scheme, using fertilisers and micro nutrients as per the SHC, getting assistance from agricultural officers, recommendations suitable to their soils, sample test values representing their soils, results provided in time, etc. This indicates that the SHC scheme is more pro-poor compared to other government programmes.

It is prescribed that in a grid of 10 hectare of dry land, the soil sample should be collected from the land of all large and medium farmers falling in the grid and also should cover some plots of small farmers through random selection. However, in practice, most of the soil samplers collect sub-samples from 34 locations of grid farmers and don't covering small farmers' plots (Table 24). Field surveys show that most of the sub-samples are collected from only one plot of the grid (large) farmers. About $51 \%$ of the farmers said that sub-samples were taken from only one plot of the farmers, whereas about $28 \%$ of the farmers responded that sub-samples were taken from a few plots of the farmers, and about $18 \%$ of the farmers said that the sub-sample was taken from all the plots. However, if the soil is homogenous, representativeness may not be lost with small a number of sub-samples, but if the soil variability is higher, samplers must collect samples from each plot and test them separately. Because of this reason, the study suggests that the grid size should vary with soil variability so that soil test values represent soils correctly without any sampling error. In North-East and South India, there is better coverage compared to other states. A few farmers also reported (2.5\%) that they received SHCs without any sample taken from their fields. Many of the field extension officers don't know the exact procedure to be followed in soil sample collection, and they said that they don't see the field manual on soil sample collection. Hence, every block-level office should have the soil sampling manual, and this needs to be properly explained to the soil sample collectors. There is a need for standard protocols for soil sample collection. The soil sample collection of different soil conditions and seasons needs to be standardised. The procedures should vary according to the variability of soil, i.e. the slope of the land, the water sources, etc. 
Table 24: Number of plots covered in soil testing across zones

\begin{tabular}{|l|l|l|l|l|}
\hline Zone & All (\%) & Some (\%) & One plot (\%) & None (\%) \\
\hline Central & 63.4 & 19.2 & 12.7 & 4.7 \\
\hline East & 6.6 & 5.1 & 84.0 & 4.3 \\
\hline North-East & 18.9 & 55.6 & 23.0 & 2.5 \\
\hline North & 1.5 & 54.3 & 41.0 & 3.2 \\
\hline South & 42.8 & 20.3 & 36.3 & 0.6 \\
\hline West & 25.6 & 21.6 & 45.5 & 7.2 \\
\hline All & 25.4 & 32.2 & 39.0 & 3.3 \\
\hline
\end{tabular}

According to farm size groups, $68 \%$ among small and marginal farmers indicated that only one plot of their land was covered for soil sample collection, about 19\% mentioned that some of their plots were covered, and only $14.5 \%$ mentioned that all their plots were covered for soil sampling (Table 25). While $17.5 \%$ of large farmers said that all their plots were covered for sampling, $26 \%$ said that only one plot was considered for sample collection, and the remaining 55\% said that some of their plots were considered for sample collection. Farmers who have land with less irrigated area also mentioned that their soils are covered in soil sampling, which is a good sign. There was no significant difference between developed and less developed states in the coverage of the samples (Tables 25 to 27).

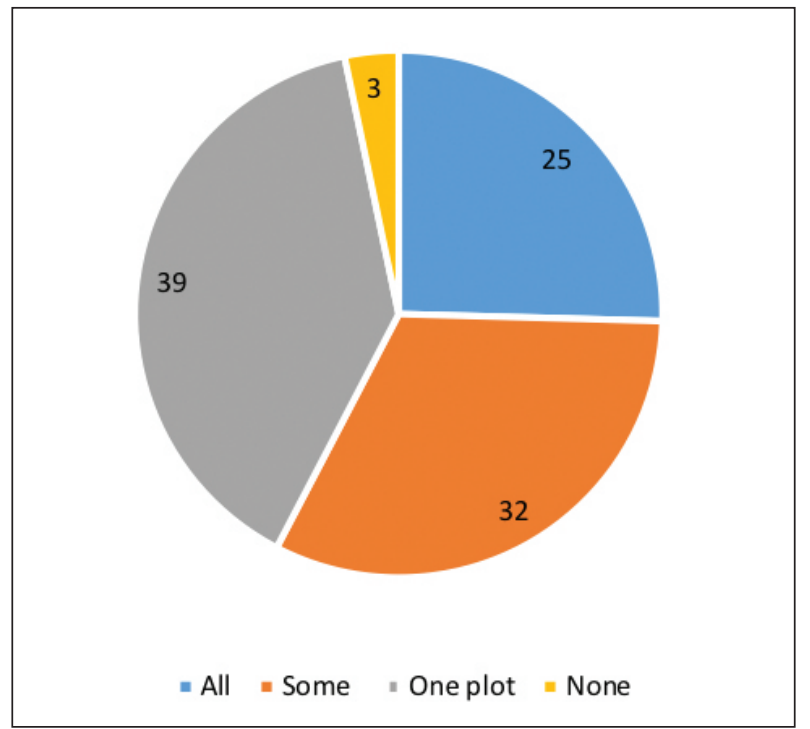

Fig. 12: Number of Plots Covered for Soil Testing

Table 25: Number of plots covered in soil testing across size classes

\begin{tabular}{|l|l|l|l|l|}
\hline Size class & All (\%) & Some $(\%)$ & One & $(\%)$ None $(\%)$ \\
\hline Large & 18.9 & 37.1 & 42.4 & 1.6 \\
\hline Medium & 35.6 & 21.8 & 36.6 & 6.1 \\
\hline Small and marginal & 25.1 & 36.5 & 35.1 & 3.3 \\
\hline All & 25.4 & 32.2 & 39.0 & 3.3 \\
\hline
\end{tabular}


Table 26: Number of plots Covered in Soil Testing

\begin{tabular}{|l|l|l|l|l|}
\hline State group & All (\%) & Some (\%) & One (\%) & None (\%) \\
\hline Developed & 29.8 & 32.5 & 35.0 & 2.7 \\
\hline Less developed & 13.9 & 31.5 & 49.5 & 5.1 \\
\hline Total & 25.4 & 32.2 & 39.0 & 3.3 \\
\hline
\end{tabular}

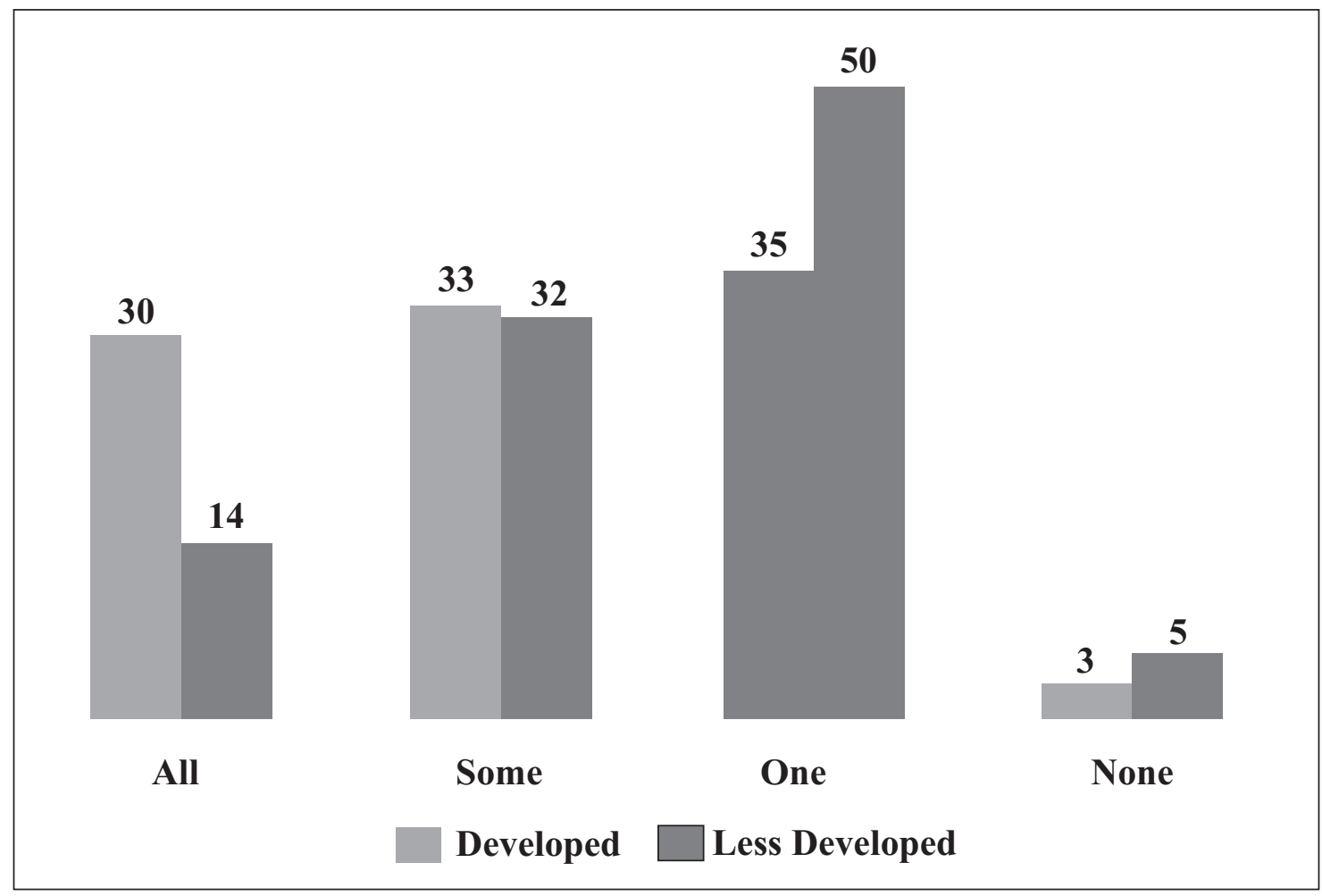

Fig. 13: Number of plots covered in developed and less developed states

Table 27: Number of plots covered in irrigated groups

\begin{tabular}{|l|l|l|l|l|}
\hline \% irrigated group & All (\%) & Some (\%) & One (\%) & None (\%) \\
\hline Less irrigated & 48.5 & 24.7 & 23.2 & 3.7 \\
\hline Medium irrigated & 19.9 & 44.4 & 28.1 & 7.6 \\
\hline Mostly irrigated & 19.6 & 33.2 & 44.3 & 2.9 \\
\hline All & 25.4 & 32.2 & 39.0 & 3.3 \\
\hline
\end{tabular}

\section{Source of Information}

Most of the information was provided by agricultural extension officers and agricultural officers.

KVKs and NGOs are active in North-East and Western India. The role of KVKs and NGOs should be highlighted and encouraged by the government for easy dissemination of information (Table 28). 
Table 28: Zone-wise sources of information about the SHC content

\begin{tabular}{|l|l|l|l|l|}
\hline Region & \multicolumn{4}{|l|}{ \% of the farmers received information from } \\
\hline & KVK & AEO/AOs & $\begin{array}{l}\text { Scientists of } \\
\text { SAU/ICAR }\end{array}$ & NGOs \\
\hline Central & 39.3 & 58.8 & 1.5 & 0.4 \\
\hline East & 5.4 & 87.4 & 4.8 & 2.4 \\
\hline North-East & 10.6 & 77.5 & 2.8 & 9.1 \\
\hline North & 5.8 & 89.8 & 4.2 & 0.2 \\
\hline South & 6.9 & 85.6 & 3 & 4.5 \\
\hline West & 1.0 & 90.1 & 3.4 & 5.5 \\
\hline All & 10.3 & 84.6 & 2.6 & 2.5 \\
\hline
\end{tabular}

Main Source of Information (\%)

Scientist of SAU / ICAR, 2.6

KVK, 10.3

\author{
AEO/AOs, 84.6 \\ KVK \\ AEO / AOs \\ Scientist of SAU / ICAR \\ NGO'S
}

Fig. 14: Main source of information (\%)

KVKs and NGOs are active in providing information in less developed states and also cover most of the small and marginal farmers (Table 29) as the extension system in the less developed states are not able to cover all the farmers, given the shortage of skilled workforce and infrastructure (Table $30 \& 31$ ). "Less irrigated" farmers mostly got information from AEOs/AOs, while KVKs and NGOs mostly provide information to medium and mostly irrigated farmers (Table 30). 
Table 29: Source of information about SHC content across size classes

\begin{tabular}{|l|l|l|c|c|}
\hline \multirow{2}{*}{ Size class } & \multicolumn{4}{|c|}{ \% of the farmers received information from } \\
\cline { 2 - 5 } & KVK & AEO/AOs & $\begin{array}{c}\text { Scientists of } \\
\text { SAU/ICAR }\end{array}$ & NGOs \\
\hline Large & 18.4 & 76.1 & 3.2 & 2.3 \\
\hline Medium & 12.1 & 83.1 & 2.9 & 1.9 \\
\hline Small \& Marginal & 5.0 & 90.2 & 1.2 & 3.6 \\
\hline All & 10.3 & 84.6 & 2.6 & 2.5 \\
\hline
\end{tabular}

Table 30: Source of information about SHC content by state groups

\begin{tabular}{|l|l|l|l|c|}
\hline State group & KVK & AEO/AOs & $\begin{array}{l}\text { Scientists of } \\
\text { SAU/ICAR }\end{array}$ & NGOs \\
\hline Developed & 8.8 & 86.6 & 3.1 & 1.5 \\
\hline Less developed & 10.9 & 81.9 & 2.1 & 5.1 \\
\hline Total & 10.3 & 84.6 & 2.6 & 2.5 \\
\hline
\end{tabular}

Table 31: Source of information about SHC content by level of irrigation

\begin{tabular}{|l|l|l|l|c|}
\hline \multirow{2}{*}{$\%$ irrigated group } & \multicolumn{4}{|c|}{$\%$ of the farmers received information from } \\
\cline { 2 - 5 } & KVK & AEO/AOs & $\begin{array}{l}\text { Scientist of } \\
\text { SAU/ICAR }\end{array}$ & NGO's \\
\hline Less irrigated & 5.3 & 89.7 & 1.5 & 3.5 \\
\hline Medium irrigated & 4.5 & 88.9 & 2.6 & 4.0 \\
\hline Mostly irrigated & 12.8 & 80.8 & 4.1 & 2.3 \\
\hline All & 10.3 & 84.6 & 2.6 & 2.5 \\
\hline
\end{tabular}

Perceptions about SHC benefits

On an average, $70 \%$ of the farmers indicated that they benefited from SHC, while the remaining suggested improvement (Table 32). In most regions, except North-East, farmers feel that the benefits from the SHC scheme are huge in terms of reduction in fertiliser use and cost of cultivation and increased yields. About $45.5 \%$ of the farmers are inclined to go to private STLs. About $23.3 \%$ of the sample farmers are willing to pay for the services. However, farmers are willing to pay only in the North and the East as government machinery does not meet the expectations of the farmers in these zones. The zone-wise, farm-size-category-wise, and social-group-wise farmers' perceptions were given in Table 32, Table 33, and Table 34, respectively. It was observed that the farmers in less developed states did not benefit as much as farmers in developed states (Table 35). A majority of the farmers mentioned that they benefited through: 
$\checkmark$ Reduction in fertiliser use

$\checkmark$ Identification and application of micro nutrients

$\checkmark$ Increase in yield

$\checkmark$ Knowledge gain

Farmers suggest the following:

$\checkmark$ They should get information in time

$\checkmark$ There is a need for more awareness camps

$\checkmark$ Recommended inputs should be provided free/on a subsidy basis by the government

Table 32: Farmers perceptions about SHC across Zones

\begin{tabular}{|c|c|c|c|c|c|c|}
\hline \multirow[b]{2}{*}{ Zone } & \multicolumn{4}{|c|}{$\%$ of Sample Farmers } & \multirow[b]{2}{*}{$\begin{array}{c}\text { Type of } \\
\text { benefits (by } \\
\text { priority) }\end{array}$} & \multirow[b]{2}{*}{$\begin{array}{c}\text { Nature of } \\
\text { improvement }\end{array}$} \\
\hline & Benefitting & $\begin{array}{c}\text { Need } \\
\text { improvement }\end{array}$ & $\begin{array}{l}\text { Willing to } \\
\text { go to } \\
\text { private } \\
\text { STL }\end{array}$ & $\begin{array}{l}\text { Willing } \\
\text { to pay }\end{array}$ & & \\
\hline Central & 80.8 & 73.6 & 7.6 & 16.7 & $\begin{array}{l}\text { Reduce } \\
\text { fertiliser use }\end{array}$ & $\begin{array}{c}\text { Timely } \\
\text { distribution of } \\
\text { SHCs }\end{array}$ \\
\hline East & 84.8 & 83.7 & 47.8 & 13.6 & $\begin{array}{l}\text { Reduce } \\
\text { fertiliser use }\end{array}$ & $\begin{array}{l}\text { Sample to be } \\
\text { taken from all } \\
\text { fields }\end{array}$ \\
\hline $\begin{array}{l}\text { North - } \\
\text { East }\end{array}$ & 15.9 & 13.6 & 42.9 & 13.1 & Reduce cost & $\begin{array}{c}\text { Subsidised } \\
\text { micro - nutrient } \\
\text { supply }\end{array}$ \\
\hline North & 63.3 & 12.5 & 31.9 & 22.4 & $\begin{array}{c}\text { Awareness } \\
\text { about soil } \\
\text { nutrition }\end{array}$ & $\begin{array}{c}\text { Make farmers } \\
\text { aware about } \\
\text { SHC }\end{array}$ \\
\hline South & 86.6 & 24.7 & 12.1 & 10.7 & $\begin{array}{l}\text { Save fertiliser } \\
\text { doses }\end{array}$ & $\begin{array}{l}\text { Information } \\
\text { about SHC in } \\
\text { time }\end{array}$ \\
\hline West & 86.8 & 10.9 & 43.0 & 41.3 & $\begin{array}{l}\text { Increase of } \\
\text { production }\end{array}$ & $\begin{array}{c}\text { Recommended } \\
\text { practices in more } \\
\text { understandable } \\
\text { ways }\end{array}$ \\
\hline All & 73.6 & 29.1 & 32.4 & 19.5 & & \\
\hline
\end{tabular}

Table 33: Farmers perceptions about SHC across Size classes

\begin{tabular}{|l|c|c|c|c|c|c|}
\hline \multirow{2}{*}{$\begin{array}{l}\text { Region/ } \\
\text { State }\end{array}$} & Benefitting & $\begin{array}{c}\text { Need } \\
\text { improvement }\end{array}$ & $\begin{array}{c}\text { Willing to } \\
\text { go to private } \\
\text { STL }\end{array}$ & $\begin{array}{c}\text { Willing } \\
\text { to pay }\end{array}$ & $\begin{array}{c}\text { Type of } \\
\text { benefits } \\
\text { (by priority) }\end{array}$ & $\begin{array}{c}\text { Nature of } \\
\text { improvement }\end{array}$ \\
\hline Large & 82.9 & 26.4 & 19.2 & 17.1 & $\begin{array}{c}\text { Reduce } \\
\text { fertiliser use }\end{array}$ & $\begin{array}{c}\text { Give the SHC } \\
\text { reports in time }\end{array}$ \\
\hline Medium & 73.8 & 26.7 & 27.5 & 19.4 & $\begin{array}{c}\text { Knowledge } \\
\text { about SHC }\end{array}$ & $\begin{array}{c}\text { Free nutrients } \\
\text { from govt }\end{array}$ \\
\hline $\begin{array}{l}\text { Small } \\
\text { and } \\
\text { marginal }\end{array}$ & 68.4 & 33.1 & 44.6 & 20.9 & Get knowledge & $\begin{array}{c}\text { Free/subsidized } \\
\text { micro nutrients } \\
\text { from govt }\end{array}$ \\
\hline All & 73.6 & 29.1 & 32.4 & 19.5 & & \\
\hline
\end{tabular}




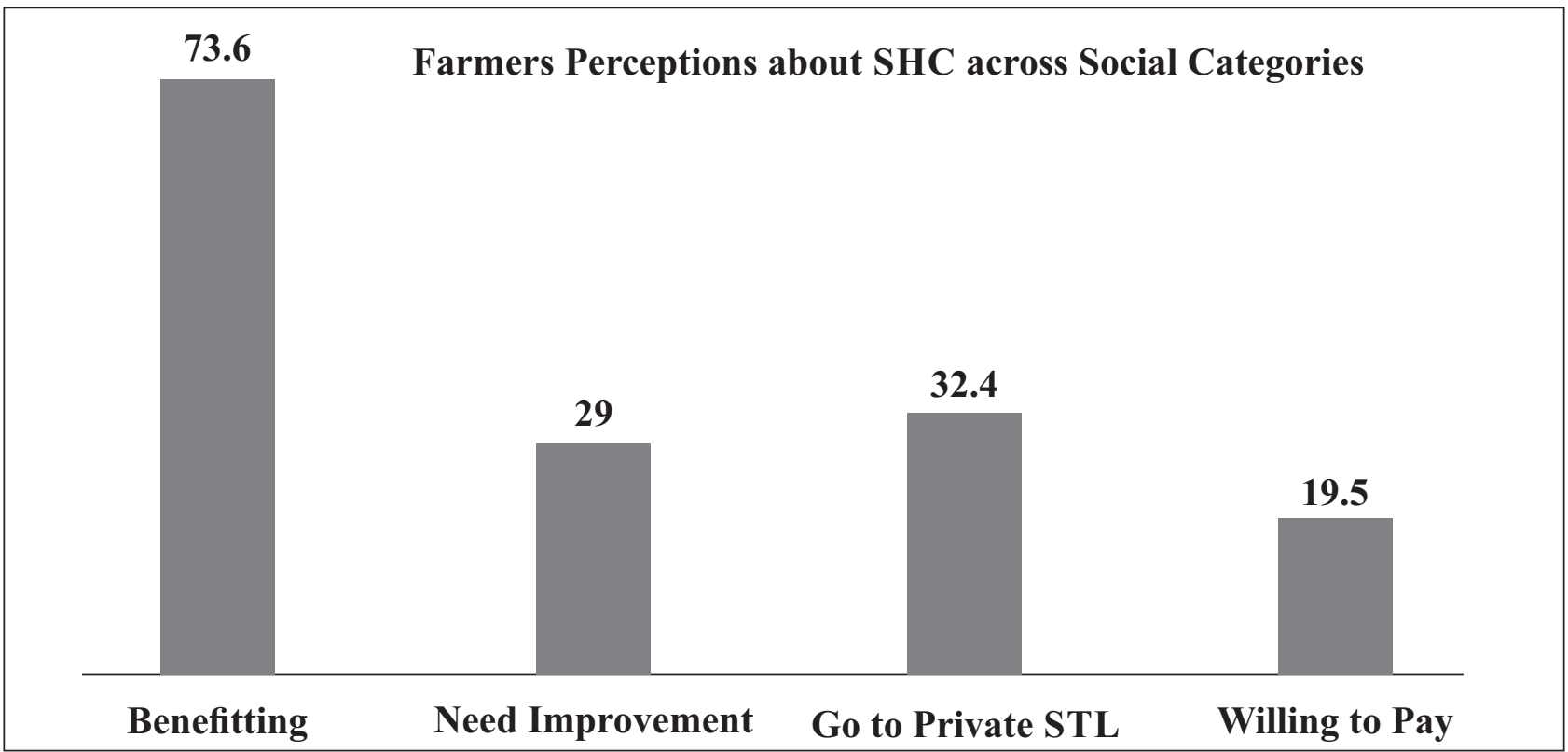

Fig. 15: Farmers perceptions about SHC across social categories

Table 34: Farmers perceptions about SHC across Social Categories

\begin{tabular}{|c|c|c|c|c|c|c|}
\hline \multirow{2}{*}{ Region/State } & \multicolumn{4}{|c|}{ \% of sample farmers } & \multicolumn{1}{|c|}{} \\
\cline { 2 - 7 } & Benefitting & $\begin{array}{l}\text { Need } \\
\text { improvement }\end{array}$ & $\begin{array}{l}\text { Willing } \\
\text { to go to } \\
\text { private } \\
\text { STL }\end{array}$ & $\begin{array}{l}\text { Willing } \\
\text { to pay }\end{array}$ & $\begin{array}{c}\text { Type of } \\
\text { benefits } \\
\text { (by priority) }\end{array}$ & $\begin{array}{c}\text { Nature of } \\
\text { improvement* }\end{array}$ \\
\hline OCs & 78.3 & 23.5 & 37.1 & 21.3 & $\begin{array}{l}\text { Reduces } \\
\text { fertilisers } \\
\text { use }\end{array}$ & $\begin{array}{l}\text { Give the SHC } \\
\text { reports in time }\end{array}$ \\
\hline BCs & 82.8 & 33.5 & 18.5 & 19.5 & $\begin{array}{l}\text { Reduces } \\
\text { cost }\end{array}$ & $\begin{array}{l}\text { More trainings } \\
\text { needed }\end{array}$ \\
\hline SC/STs & 50.8 & 34.9 & 41.3 & 15.8 & $\begin{array}{l}\text { Awareness } \\
\text { about soils }\end{array}$ & $\begin{array}{l}\text { Free soil } \\
\text { nutrients by } \\
\text { govt }\end{array}$ \\
\hline All & 73.6 & 29.1 & 32.4 & 19.5 & $\begin{array}{l}\text { Reduces } \\
\text { fertiliser } \\
\text { use }\end{array}$ & $\begin{array}{l}\text { More trainings } \\
\text { needed }\end{array}$ \\
\hline
\end{tabular}

Table 35: Farmers perceptions about SHC across states

\begin{tabular}{|l|c|c|c|c|c|c|}
\hline \multirow{2}{*}{ State Group } & \multicolumn{4}{|c|}{ \% of sample farmers } & & \\
\cline { 2 - 7 } & Benefitting & $\begin{array}{c}\text { Need } \\
\text { improvement }\end{array}$ & $\begin{array}{l}\text { Willing } \\
\text { to go to } \\
\text { private } \\
\text { STL }\end{array}$ & $\begin{array}{c}\text { Willing } \\
\text { to pay }\end{array}$ & $\begin{array}{c}\text { Type of } \\
\text { benefits } \\
\text { (by priority) }\end{array}$ & $\begin{array}{c}\text { Nature of } \\
\text { improvement* }\end{array}$ \\
\hline Developed & 91.6 & 32.9 & 32.2 & 21.8 & $\begin{array}{l}\text { Optimal } \\
\text { dose of } \\
\text { fertilisers }\end{array}$ & $\begin{array}{l}\text { Give } \\
\text { information of } \\
\text { SHC in time }\end{array}$ \\
\hline $\begin{array}{l}\text { Less } \\
\text { developed }\end{array}$ & 26.0 & 18.9 & 32.6 & 13.6 & $\begin{array}{l}\text { Awareness } \\
\text { about SHC }\end{array}$ & $\begin{array}{l}\text { Free inputs from } \\
\text { agricultural dept }\end{array}$ \\
\hline All & 73.6 & 29.1 & 32.4 & 19.5 & & \\
\hline
\end{tabular}




\section{Farmers Perceptions about SHC across States}

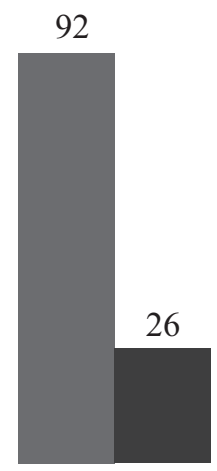

Benefitting

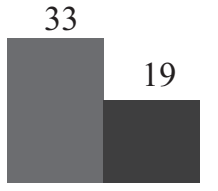

Need Improvement

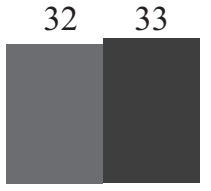

Go to Private STL

Less Developed

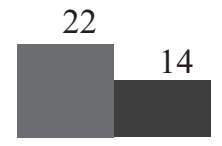

Willing to pay

Fig. 16: Farmers' perceptions about SHC across states

Table 36 shows that the "mostly irrigated" farmers mentioned that there is a need for improvement in the SHC scheme. About $50 \%$ of them are willing to go for private soil testing labs and about $25 \%$ of them are willing to pay.

Table 36: Farmers' perceptions about SHC Irrigated Groups

\begin{tabular}{|l|c|l|l|l|l|l|}
\hline \multirow{2}{*}{$\begin{array}{l}\text { \% irrigated } \\
\text { groups }\end{array}$} & \multicolumn{4}{|c|}{ \% of sample farmers } & \multicolumn{1}{|c|}{} \\
\cline { 2 - 7 } & Benefitting & $\begin{array}{l}\text { Need } \\
\text { improvement }\end{array}$ & $\begin{array}{l}\text { Go to } \\
\text { private } \\
\text { STL }\end{array}$ & $\begin{array}{l}\text { Willing } \\
\text { to pay }\end{array}$ & $\begin{array}{c}\text { Type of } \\
\text { benefits } \\
\text { (by priority) }\end{array}$ & $\begin{array}{c}\text { Nature of } \\
\text { improvement }\end{array}$ \\
\hline Less irrigated & 78.6 & 17.8 & 13.7 & 16.8 & $\begin{array}{l}\text { Awareness } \\
\text { about SHC }\end{array}$ & $\begin{array}{l}\text { Timely } \\
\text { Information } \\
\text { about SHC }\end{array}$ \\
\hline $\begin{array}{l}\text { Medium } \\
\text { irrigated }\end{array}$ & 44.4 & 21.1 & 39.2 & 24.0 & $\begin{array}{l}\text { Save } \\
\text { fertiliser doses }\end{array}$ & $\begin{array}{l}\text { Free fertilisers } \\
\text { from the dept. }\end{array}$ \\
\hline Mostly irrigated & 74.9 & 32.9 & 36.8 & 19.9 & $\begin{array}{l}\text { Reduces } \\
\text { fertiliser use }\end{array}$ & $\begin{array}{l}\text { Make farmers } \\
\text { aware about } \\
\text { SHC }\end{array}$ \\
\hline All & 73.6 & 29.1 & 32.4 & 19.5 & $\begin{array}{l}\text { Reduces } \\
\text { fertiliser use }\end{array}$ & $\begin{array}{l}\text { Timely } \\
\text { Information } \\
\text { about SHC }\end{array}$ \\
\hline
\end{tabular}

\subsection{Outcomes (Input Use and Cost Per Hectare) of the SHC Scheme}

The impact of SHC was assessed for three important crops, viz paddy, cotton, and soybean, by comparing fertiliser use and yield before possessing SHC and after following the recommendations of SHC. The study has assessed change in the area under the crops, use of major fertilisers (urea, DAP/SSP and MoP), cost of cultivation, and yields. For these three crops farmers, reported a decline in the area after the SHC scheme, indicating that most of the farmers have diversified to less inputintensive crops from more input-intensive crops, such as paddy and cotton, after the introduction of SHCs. Overall, paddy farmers reduced urea use by about $13 \%$, DAP/SSP by about $12 \%$, and 
Potassium by about $4 \%$. This is a healthy sign of moving towards a balanced use of fertilisers. All the three crops showed a decline in costs per acre by about 8 to $10 \%$. There was a substantial increase in the use of manures, especially in paddy, which resulted in decreased cost of cultivation per unit area. On the other hand, soybean farmers indicated an increase in fertiliser use, although marginally (Table 37). Crop yields have increased slightly after introducing SHC to all three crops. Among different farm size classes, small and marginal as well as large farmers experienced decline in costs in all the selected crops, while medium farmers reported decline in the case of paddy and soybean crops (Table 38).

Table 37. Impact of SHC on fertiliser use, costs, and crop yields (per ha)

\begin{tabular}{|c|c|c|c|c|c|c|c|c|c|c|c|c|c|c|}
\hline $\begin{array}{l}\text { Crop/re } \\
\text { gion }\end{array}$ & $\begin{array}{l}\mathrm{S} \\
\mathrm{H} \\
\mathrm{C}\end{array}$ & Cost C2 & $\begin{array}{l}\text { Gross } \\
\text { return }\end{array}$ & $\begin{array}{c}\text { Net } \\
\text { Return }\end{array}$ & $\begin{array}{l}\text { Yield } \\
\text { (qtl) }\end{array}$ & N (kg) & $P(\mathrm{~kg})$ & K (kg) & $\begin{array}{c}\text { Fertili } \\
\text { ser } \\
(\mathrm{kg})\end{array}$ & $\begin{array}{l}\text { Fert } \\
\text { (Rs) }\end{array}$ & $\begin{array}{l}\text { Man } \\
\text { ure } \\
\text { (qtl) }\end{array}$ & $\begin{array}{c}\text { Manure } \\
\text { (Rs.) }\end{array}$ & $\begin{array}{l}\text { Cost } \\
\mathrm{A} 2+\mathrm{FL}\end{array}$ & $\begin{array}{l}\text { Returns } \\
\text { over } \\
\text { variable } \\
\text { cost A2+FL }\end{array}$ \\
\hline \multicolumn{15}{|l|}{ Cotton } \\
\hline \multirow[t]{2}{*}{ South } & B & 66613 & 80500 & 13887 & 17.5 & 124 & 64 & 33 & 221 & 6904 & 9 & 1004 & 49136 & 31364 \\
\hline & $A$ & 63283 & 82800 & 19517 & 18 & 105 & 60 & 28 & 193 & 5912 & 12 & 1256 & 44106 & 38694 \\
\hline \multirow[t]{2}{*}{ West } & $B$ & 73327 & 96600 & 23273 & 21 & 131 & 62 & 22 & 215 & 7172 & 22 & 2553 & 52730 & 43870 \\
\hline & $\mathrm{A}$ & 70807 & 101200 & 30393 & 22 & 106 & 55 & 20 & 181 & 5976 & 28 & 3273 & 47736 & 53464 \\
\hline \multirow[t]{2}{*}{ Total } & B & 69970 & 88550 & 18580 & 19.25 & 127.5 & 63 & 27.5 & 218 & 7038 & 15.5 & 1778.5 & 50933 & 37617 \\
\hline & $A$ & 67045 & 92000 & 24955 & 20 & 105.5 & 57.5 & 24 & 187 & 5944 & 20 & 2264.5 & 45921 & 46079 \\
\hline $\begin{array}{c}\% \\
\text { change }\end{array}$ & & -4.2 & 3.9 & 34.3 & 3.9 & -17.3 & -8.7 & -12.7 & -14.2 & -15.5 & 29.0 & 27.3 & -9.8 & 22.5 \\
\hline \multicolumn{15}{|l|}{ Paddy } \\
\hline \multirow[t]{2}{*}{ North } & $B$ & 54895 & 81675 & 26780 & 45 & 78 & 34 & 18 & 130 & 4373 & 9.5 & 399 & 38839 & 42836 \\
\hline & A & 52968 & 81675 & 28707 & 45 & 68 & 29 & 17 & 114 & 3786 & 10.5 & 473 & 35103 & 46572 \\
\hline \multirow[t]{2}{*}{ South } & $\mathrm{B}$ & 73886 & 92565 & 18680 & 51 & 79 & 42 & 22 & 143 & 7441 & 15.5 & 651 & 49854 & 42711 \\
\hline & A & 70397 & 96195 & 25798 & 53 & 67 & 41 & 20.5 & 128.5 & 6290 & 19 & 855 & 45218 & 50977 \\
\hline \multirow[t]{2}{*}{ Total } & $B$ & 64390.5 & 87120 & 22730 & 48 & 78.5 & 38 & 20 & 136.5 & 5907 & 12.5 & 525 & 44347 & 42773 \\
\hline & $A$ & 61682.5 & 88935 & $\begin{array}{c}27252 . \\
5\end{array}$ & 49 & 67.5 & 35 & 18.75 & $\begin{array}{c}121.2 \\
5\end{array}$ & 5038 & 14.75 & 664 & 40161 & 48774 \\
\hline $\begin{array}{c}\% \\
\text { change }\end{array}$ & & -4.2 & 2.1 & 19.9 & 2.1 & -14.0 & -7.9 & -6.3 & -11.2 & -14.7 & 18.0 & 26.4 & -9.4 & 14 \\
\hline \multicolumn{15}{|l|}{ Soybean } \\
\hline \multirow[t]{2}{*}{ South } & $B$ & 24459 & 30800 & 6341 & 11 & 31 & 46 & 6 & 83 & 2074 & 4 & 572 & 21910 & 8890 \\
\hline & $\mathrm{A}$ & 23529 & 30800 & 10271 & 11 & 26 & 42 & 6 & 74 & 1850 & 5 & 762 & 19500 & 11300 \\
\hline \multirow[t]{2}{*}{ West } & $B$ & 35590 & 42000 & 6410 & 15 & 30 & 45 & 6.5 & 81.5 & 3597 & 4 & 848 & 28525 & 13475 \\
\hline & $A$ & 33646 & 44800 & 11154 & 16 & 26.5 & 38 & 7 & 71.5 & 2976 & 5 & 1087 & 26552 & 18248 \\
\hline \multirow[t]{2}{*}{ Total } & $B$ & 30024.5 & 36400 & 6375.5 & 13 & 30.5 & 45.5 & 6.25 & 82.25 & 2835.5 & 4 & 710 & 25618 & 11182 \\
\hline & $A$ & 28587.5 & 37800 & $\begin{array}{c}10712 . \\
5\end{array}$ & 13.5 & 26.25 & 40 & 6.5 & 72.75 & 2413 & 5 & 924.5 & 23026 & 14774 \\
\hline $\begin{array}{c}\% \\
\text { change }\end{array}$ & & -4.8 & 3.8 & 68.0 & 3.8 & -13.9 & -12.1 & 4.0 & -11.6 & -14.9 & 25.0 & 30.2 & -8.7 & 32.1 \\
\hline
\end{tabular}

Note: $\mathrm{B}=$ Before soil health card; $\mathrm{A}=\mathrm{After}$ soil health card scheme * because of the lack of availability of bio-fertilisers farmers are not able to adopt.

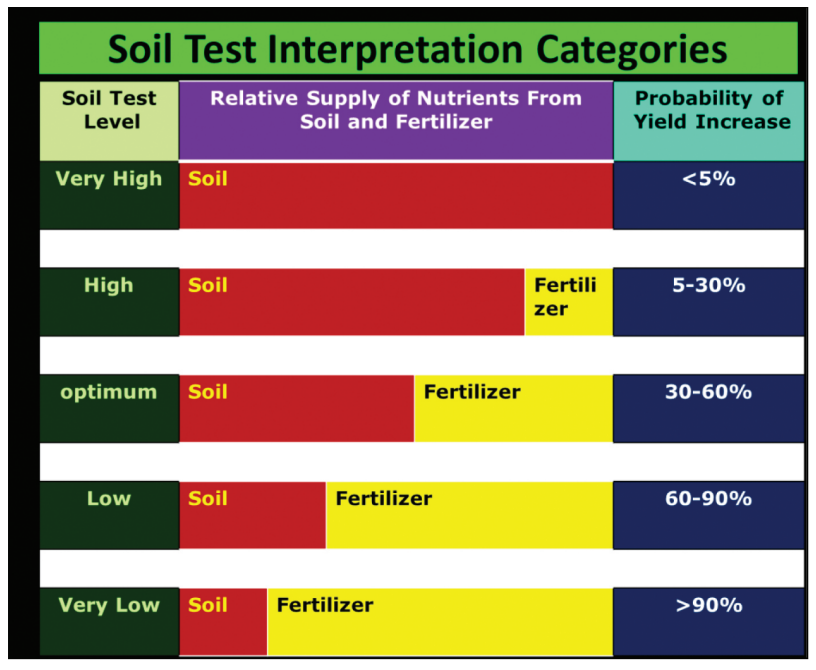

Fig 17: Soil test interpretation categories 
Fig.18: Azolla- a potential source of bio-fertiliser

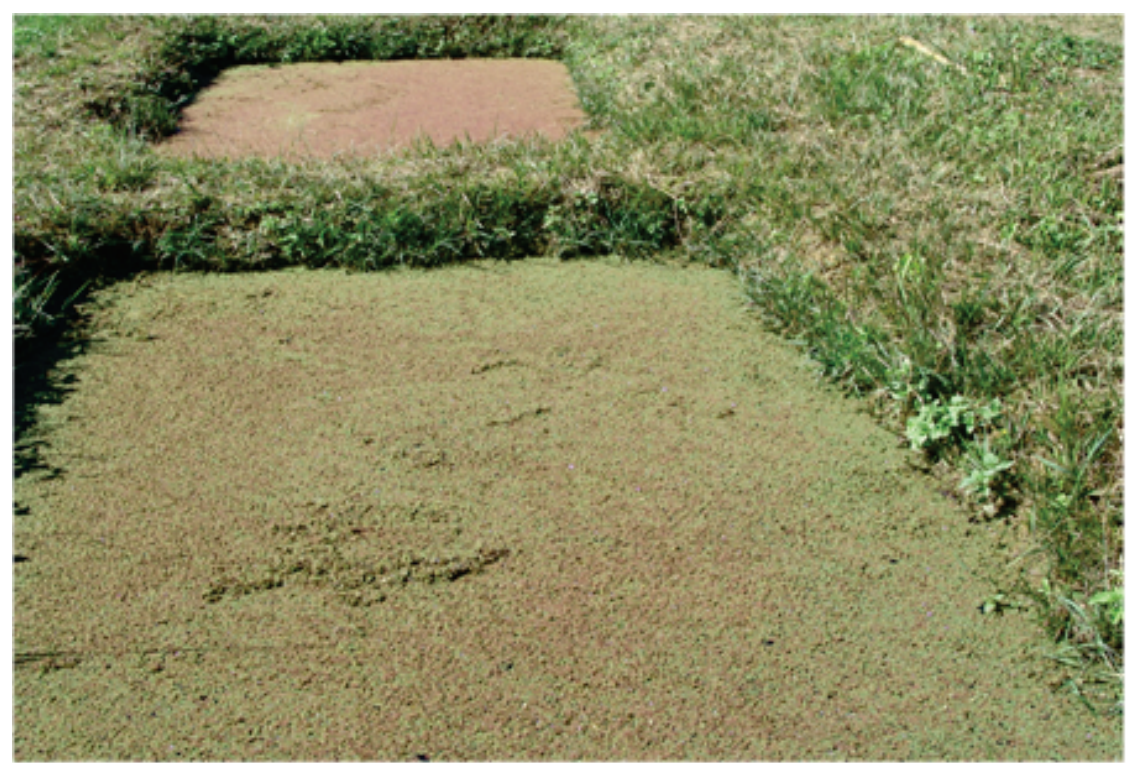

Table 38. Impact of SHC on fertiliser use, costs, and crop yields by farm size category

\begin{tabular}{|c|c|c|c|c|c|c|c|c|c|c|c|c|c|c|}
\hline $\begin{array}{l}\text { Crop/Far } \\
\text { m size }\end{array}$ & $\begin{array}{l}\text { SH } \\
\text { C }\end{array}$ & $\begin{array}{l}\text { Cost } \\
\text { C2 }\end{array}$ & $\begin{array}{l}\text { Gross } \\
\text { return }\end{array}$ & $\begin{array}{l}\text { Net } \\
\text { Return }\end{array}$ & $\begin{array}{l}\text { Yield } \\
\text { (qtl) }\end{array}$ & N (kg) & P (kg) & K (kg) & $\begin{array}{l}\text { Fertilis } \\
\text { er (kg) }\end{array}$ & Fert. (Rs) & $\begin{array}{l}\text { Manure } \\
\text { (qtl) }\end{array}$ & $\begin{array}{l}\text { Man } \\
\text { ure } \\
\text { (Rs.) }\end{array}$ & $\begin{array}{l}\text { Cost } \\
\text { A2+FL }\end{array}$ & \begin{tabular}{|l} 
Returns \\
over \\
variable \\
cost $\mathbf{A 2}+\mathrm{FL}$
\end{tabular} \\
\hline \multicolumn{15}{|l|}{ Cotton } \\
\hline \multirow[t]{2}{*}{ Large } & B & 53173 & 87400 & 34227 & 19 & 128.5 & 66 & 30 & 224.5 & 7144 & 14 & 1580 & 48990 & 38410 \\
\hline & A & 49891 & 92000 & 46709 & 20 & 108.5 & 59 & 26 & 193.5 & 6170 & 16 & 2045 & 44150 & 47850 \\
\hline$\%$ change & & -6.2 & 5.3 & 36.5 & 5.3 & -15.6 & -10.6 & -13.3 & -13.8 & -13.6 & 14.3 & 29.4 & -9.9 & 15 \\
\hline \multirow[t]{2}{*}{ S\&MF } & B & 63136 & 87400 & 24264 & 18 & 126.5 & 60 & 25 & 211.5 & 6934 & 17 & 1973 & 52877 & 34523 \\
\hline & $\mathrm{A}$ & 61701 & 92000 & 30299 & 18.5 & 102.75 & 56 & 22 & 180.75 & 5725 & 24.45 & 2485 & 47717 & 44283 \\
\hline$\%$ change & & -2.3 & 5.3 & 24.9 & 2.8 & -18.8 & -6.7 & -12.0 & -14.5 & -17.4 & 43.8 & 26.0 & -9.8 & 15 \\
\hline \multicolumn{15}{|l|}{ Paddy } \\
\hline \multirow[t]{2}{*}{ Large } & B & 71075 & 99825 & 28750 & 55 & 85 & 43.25 & 21 & 149.25 & 6195 & 11.75 & 485 & 48024 & 51801 \\
\hline & $\mathrm{A}$ & 68995 & 103455 & 34460 & 57 & 69 & 38 & 19.5 & 126.5 & 5115 & 13.75 & 580 & 44077 & 59378 \\
\hline$\%$ change & & -2.9 & 3.6 & 19.9 & 3.6 & -18.8 & -12.1 & -7.1 & -15.2 & -17.4 & 17.0 & 19.6 & -8.2 & 12 \\
\hline \multirow[t]{2}{*}{ S\&MF } & B & 57690 & 73508 & 15818 & 40.5 & 72 & 33 & 19.2 & 124.2 & 5617 & 13 & 659 & 40670 & 32838 \\
\hline & $\mathrm{A}$ & 54360 & 73961 & 19601 & 40.75 & 66 & 31.7 & 18.2 & 115.9 & 4956 & 15.5 & 878 & 36244 & 37717 \\
\hline$\%$ change & & -5.8 & 0.6 & 23.9 & 0.6 & -8.3 & -3.9 & -5.2 & -6.7 & -11.8 & 19.2 & 33.2 & -10.9 & 11 \\
\hline \multicolumn{15}{|l|}{ Soybean } \\
\hline \multirow[t]{2}{*}{ Large } & $\mathrm{B}$ & 31082 & 36400 & 5318 & 13 & 33 & 47 & 8 & 88 & 2811 & 4 & 595 & 25811 & 10589 \\
\hline & A & 29620 & 36400 & 6780 & 13 & 28 & 42 & 8.7 & 78.7 & 2500 & 5 & 850 & 23472 & 12928 \\
\hline$\%$ change & & -4.7 & 0.0 & 27.5 & 0.0 & -15.2 & -10.6 & 8.7 & -10.6 & -11.1 & 25.0 & 42.9 & -9.1 & 9 \\
\hline \multirow[t]{2}{*}{ S\&MF } & B & 28984 & 36400 & 7416 & 13 & 28 & 44 & 7 & 79 & 2524 & 4.5 & 790 & 24625 & 11775 \\
\hline & $\mathrm{A}$ & 27560 & 39200 & 11640 & 14 & 24.55 & 38 & 7 & 69.55 & 2050 & 5.65 & 933 & 22582 & 16618 \\
\hline$\%$ change & & -4.9 & 7.7 & 57.0 & 7.7 & -12.3 & -13.6 & 0.0 & -12.0 & -18.8 & 25.6 & 18.1 & -8.3 & 16 \\
\hline
\end{tabular}

Note: $\mathrm{B}=$ before SHC scheme; $\mathrm{A}=$ after SHC scheme 
Table 39: Status according to longevity of card (cotton/ha)

\begin{tabular}{|c|c|c|c|c|c|c|c|c|c|c|c|c|c|}
\hline $\begin{array}{l}\text { Before } \\
\text { SHC } \\
\text { scheme }\end{array}$ & Cost C2 & $\begin{array}{l}\text { Return } \\
\text { over } \\
\text { Cost C2 } \\
\end{array}$ & $\begin{array}{l}\text { Net } \\
\text { Return }\end{array}$ & $\begin{array}{l}\text { Yield } \\
(\mathrm{q} / \mathrm{ha})\end{array}$ & $\begin{array}{l}\mathrm{N}(\mathrm{kg} \\
\text { /ha) }\end{array}$ & $\mathrm{p}(\mathrm{kg})$ & k (kg) & $\begin{array}{c}\text { Fertiliser } \\
(\mathrm{kg})\end{array}$ & $\begin{array}{l}\text { Fert } \\
\text { (Rs.) }\end{array}$ & $\begin{array}{l}\text { Manure } \\
\text { (Qtl) }\end{array}$ & $\begin{array}{l}\text { Manure } \\
\text { (Rs.) }\end{array}$ & $\begin{array}{l}\text { Cost } \\
\text { A2+FL }\end{array}$ & $\begin{array}{l}\text { Returns } \\
\text { over cost } \\
\text { A2+FL } \\
\end{array}$ \\
\hline Old & 70905 & 87400 & 16495 & 19 & 114 & 57 & 21 & 192 & 6381 & 24 & 2550 & 49030 & 38370 \\
\hline New & 69793 & 82800 & 13007 & 18 & 121 & 54 & 20 & 195 & 6472 & 22 & 2447 & 50083 & 32717 \\
\hline \multicolumn{14}{|c|}{$\begin{array}{l}\% \text { change } \\
\text { after SHC } \\
\text { scheme }\end{array}$} \\
\hline Old & -5.1 & 4.5 & 35 & 4.3 & -20 & -10 & -15 & -17 & -18 & 31 & 28 & 11 & 17 \\
\hline \multirow[t]{3}{*}{ New } & -3.4 & 3.4 & 33 & 3.5 & -15 & -8 & -11 & -12 & -14 & 27 & 27 & 9.2 & 14 \\
\hline & -4.25 & 3.95 & 34 & 3.9 & -17.5 & -9 & -13 & -14.5 & -16 & 29 & 27.5 & 10.1 & 15.5 \\
\hline & -4.2 & 3.9 & 34.3 & 3.9 & -17.3 & -8.7 & -12.7 & -14.2 & -15.5 & 29.0 & 27.3 & -10.0 & 15.7 \\
\hline
\end{tabular}

Table 39 shows that in case of the cotton crop, farmers who possessed SHC for one year reduced fertiliser use significantly compared to farmers who possessed SHC just three months earlier. Yields increased by near about $4 \%$ in both old and new cluster groups, while cost of cultivation was significantly lower (3.4\%) compared to the farmers who possessed SHC for one year $(5.1 \%)$.

Table 40: Status according to longevity of card (Paddy/ha)

\begin{tabular}{|c|c|c|c|c|c|c|c|c|c|c|c|c|c|}
\hline $\begin{array}{l}\text { Percentile } \\
\text { Group based } \\
\text { on period of } \\
\text { holding SHC }\end{array}$ & Cost C2 & $\begin{array}{l}\text { Return } \\
\text { over } \\
\text { Cost C2 }\end{array}$ & \begin{tabular}{|l|} 
Net \\
Return
\end{tabular} & $\begin{array}{l}\text { Yield } \\
(\mathbf{q} / \mathbf{h a})\end{array}$ & $\begin{array}{l}\mathrm{N} \\
(\mathrm{kg})\end{array}$ & $\begin{array}{l}\text { p (kg } \\
\text { /ha) }\end{array}$ & $\mathrm{k}(\mathrm{kg})$ & $\begin{array}{c}\text { Fertiliser } \\
(\mathrm{kg})\end{array}$ & $\begin{array}{l}\text { Fert } \\
\text { (Rs.) }\end{array}$ & $\begin{array}{l}\text { Manure } \\
\text { re(q) }\end{array}$ & $\begin{array}{l}\text { Manure } \\
\text { (Rs.) }\end{array}$ & $\begin{array}{l}\text { Cost } \\
\text { A2+FL }\end{array}$ & $\begin{array}{l}\text { Returns } \\
\text { over cost } \\
\text { A2+FL }\end{array}$ \\
\hline Old & 54668 & 68970 & 14302 & 38 & 79 & 35 & 22 & 136 & 4482 & 14 & 1237 & 39646 & 29324 \\
\hline New & 55223 & 72600 & 17377 & 40 & 82 & 65 & 25 & 172 & 4570 & 13 & 1250 & 44595 & 28005 \\
\hline \multicolumn{14}{|l|}{$\begin{array}{l}\% \text { change } \\
\text { after SHC } \\
\text { scheme }\end{array}$} \\
\hline Old & -5.2 & 2.3 & 22.9 & 2.6 & -16 & -9 & -5.5 & -12.2 & -16 & 16.5 & 25 & -11 & 12 \\
\hline New & -3.2 & 2.1 & 16.85 & 1.5 & -12 & -7 & -7.2 & -10 & -13.5 & 20 & 28 & -8.5 & 10.2 \\
\hline
\end{tabular}

In case of Paddy (Table 40), yields have gone up among farmers who possessed SHC for one year (2.6 $\%)$. NPK use has been consistently less after the SHC scheme. There has been a consistent decrease in fertiliser use, which is the case across all farmer categories. Net returns of the farmers who possessed the SHC for one year (22.9\%) increased compared to the farmers who received SHC just three months earlier $(16.85 \%)$.

Table 41: Status according to longevity of card (Soybean/ha)

\begin{tabular}{|c|c|c|c|c|c|c|c|c|c|c|c|c|c|}
\hline $\begin{array}{l}\text { Percentile } \\
\text { Group based } \\
\text { on period of } \\
\text { holding SHC }\end{array}$ & Cost C2 & $\begin{array}{l}\text { Return } \\
\text { over } \\
\text { Cost C2 }\end{array}$ & $\begin{array}{l}\text { Net } \\
\text { Return }\end{array}$ & $\begin{array}{l}\text { Yield } \\
(q / h a)\end{array}$ & $\begin{array}{l}\mathrm{N} \\
(\mathrm{kg})\end{array}$ & $\begin{array}{l}\mathbf{p}(\mathrm{kg} \\
\text { /ha) }\end{array}$ & k (kg) & $\begin{array}{l}\text { Fertilser } \\
(\mathbf{k g})\end{array}$ & $\begin{array}{l}\text { Fert } \\
\text { (Rs.) }\end{array}$ & $\begin{array}{l}\text { Manure } \\
\text { re(q) }\end{array}$ & $\begin{array}{l}\text { Manure } \\
\text { (Rs.) }\end{array}$ & $\begin{array}{l}\text { Cost } \\
\text { A2+FL }\end{array}$ & $\begin{array}{l}\text { Returns } \\
\text { over cost } \\
\text { A2+FL }\end{array}$ \\
\hline Old & 28496 & 39200 & 1304 & 14 & 20 & 37 & 3 & 60 & 2687 & 5 & 937 & 23959 & 15241 \\
\hline New & 26760 & 33600 & 3840 & 12 & 22 & 35 & 4 & 61 & 2590 & 4 & 1,000 & 23052 & 10548 \\
\hline $\begin{array}{l}\% \text { change after } \\
\text { SHC scheme } \\
\text { Old }\end{array}$ & -5.8 & 4.5 & 72 & 5 & -16 & -13.8 & 5 & -13 & -16 & 27 & 33.5 & 9.8 & 23 \\
\hline New & -3.7 & 3.2 & 64 & 2.8 & -11.5 & -10.5 & 3 & -10.3 & -13.6 & 23 & 28 & 7.2 & 20.8 \\
\hline
\end{tabular}


Interestingly, fertiliser use has reduced to nearly $10-13 \%$ in soybean after SHC (Table 41). Among the farmers who possessed SHC for the last one year, crop yields increased by $5 \%$ with the reduced cost of $6 \%$. NPK use has been consistently less after the SHC scheme was observed for soybean.

Table 42: Status according to longevity of card (Pigeon pea/ha)

\begin{tabular}{|c|c|c|c|c|c|c|c|c|c|c|c|c|c|}
\hline $\begin{array}{l}\text { Percentile } \\
\text { Group of } \\
\text { month, Year } \\
\text { SHC }\end{array}$ & Cost C2 & $\begin{array}{l}\text { Return } \\
\text { over } \\
\text { Cost C2 }\end{array}$ & $\begin{array}{l}\text { Net } \\
\text { Return }\end{array}$ & $\begin{array}{l}\text { Yield } \\
\text { (q/ha) }\end{array}$ & $\begin{array}{l}\mathrm{N} \\
(\mathrm{kg})\end{array}$ & $\begin{array}{l}\mathbf{p} \\
(\mathbf{k})\end{array}$ & $\begin{array}{l}\mathrm{k} \\
(\mathrm{kg})\end{array}$ & $\begin{array}{l}\text { Fertiliser } \\
(\mathrm{kg})\end{array}$ & $\begin{array}{l}\text { Fert } \\
\text { (Rs.) }\end{array}$ & $\begin{array}{l}\text { Manure } \\
\text { (q) }\end{array}$ & $\begin{array}{l}\text { Manure } \\
\text { (Rs.) }\end{array}$ & \begin{tabular}{|l|} 
Cost \\
A2+FL
\end{tabular} & $\begin{array}{l}\text { Returns } \\
\text { over cost } \\
\text { A2+FL }\end{array}$ \\
\hline \multicolumn{14}{|l|}{$\begin{array}{l}\text { Before SHC } \\
\text { scheme }\end{array}$} \\
\hline Old & 62437 & 92398 & 29960 & 19 & 48 & 41 & 9 & 98 & 4030 & 2 & 209 & 43362 & 49036 \\
\hline New & 61950 & 91800 & 29850 & 18.5 & 47 & 40 & 10 & 97 & 4150 & 2 & 200 & 44431 & 47369 \\
\hline \multicolumn{14}{|l|}{$\begin{array}{l}\% \text { change } \\
\text { after SHC } \\
\text { scheme }\end{array}$} \\
\hline Old & -4.5 & -9.9 & -21.1 & 6.7 & -16.9 & \begin{tabular}{|l|}
-13.9 \\
\end{tabular} & -10 & -18.9 & -7 & 4.9 & 5.3 & 112 & 24 \\
\hline New & -4.5 & -9.7 & -20.4 & 5.4 & -12.8 & -10 & -7 & -16.7 & -7.2 & 5 & 7.5 & 10.5 & 21 \\
\hline
\end{tabular}

The use of fertilisers has reduced to $19 \%$ in case of pigeon pea, which is appreciable. This is a good sign, as farmers generally don't apply fertilisers for pulse crops, as indicated in Table 42. In line with this, the yields have increased slightly among the oldest SHC users (6.7\%) although from a very high base for Pigeon pea as the crop is mostly grown under rainfed conditions and farmers give lower priority to these crops. This also highlights that the design of the SHC scheme (10 ha unit) under rainfed conditions needs to be further improved.

Table 43: Status according to longevity of card (Wheat/ha)

\begin{tabular}{|c|c|c|c|c|c|c|c|c|c|c|c|c|c|}
\hline $\begin{array}{l}\text { Percentile } \\
\text { Group of } \\
\text { month, Year } \\
\text { SHC }\end{array}$ & $\begin{array}{l}\text { Cost } \\
\text { C2 }\end{array}$ & $\begin{array}{l}\text { Return } \\
\text { over } \\
\text { Cost C2 }\end{array}$ & $\begin{array}{l}\text { Net } \\
\text { Return }\end{array}$ & $\begin{array}{l}\text { Yield } \\
\text { (q/ha) }\end{array}$ & $\begin{array}{l}\mathrm{N} \\
(\mathrm{kg})\end{array}$ & $\begin{array}{l}\text { p (kg/ } \\
\text { ha) }\end{array}$ & $\begin{array}{l}\mathrm{k} \\
(\mathrm{kg})\end{array}$ & $\begin{array}{c}\text { Fertiliser } \\
\text { (kg) }\end{array}$ & $\begin{array}{l}\text { Fert } \\
\text { (Rs.) }\end{array}$ & $\begin{array}{l}\text { Manure } \\
\text { (q) }\end{array}$ & $\begin{array}{l}\text { Manure } \\
\text { (Rs.) }\end{array}$ & $\begin{array}{l}\text { Cost } \\
\text { A2+FL }\end{array}$ & $\begin{array}{l}\text { Returns } \\
\text { over cost } \\
\text { A2+FL }\end{array}$ \\
\hline \multicolumn{14}{|l|}{$\begin{array}{l}\text { Before SHC } \\
\text { scheme }\end{array}$} \\
\hline Old & 48202 & 70606 & 22404 & 34 & 106 & 49 & 5 & 160 & 4716 & 4 & 253 & 33457 & 37149 \\
\hline New & 48525 & 70514 & \begin{tabular}{|l|}
21989 \\
\end{tabular} & 35 & 110 & 48 & 6 & 164 & 4800 & 4 & 270 & 34345 & 36169 \\
\hline \multicolumn{14}{|l|}{$\begin{array}{l}\% \text { change } \\
\text { after SHC } \\
\text { scheme }\end{array}$} \\
\hline Old & -7 & 4 & 28 & 4 & -10 & -18 & -11 & -7 & -6 & 11 & 7 & 10.5 & 13 \\
\hline New & -6 & 3 & 25 & 3 & -9 & -15 & -9 & -4 & -4 & 8 & 4 & 8 & 10 \\
\hline
\end{tabular}

In the case of wheat, farmers who possessed SHC for the last one year reduced fertiliser use as well as the total cost of cultivation (Table 43). At the same time, their average yield went up by $4 \%$. Urea use reduced by $10 \%$, phosphorous use reduced by $18 \%$, and potassium use reduced by $11 \%$. As a result, the total cost came down by $7 \%$. Although yields increased among other farmers after the SHC scheme, there was no consistency in fertiliser use. 


\subsection{Success stories and potential benefits of the SHC scheme}

More intensive data was collected from 157 farmers across the states during the study (Table 44). This section illustrates the changes observed among these farmers. Out of 157 farmers, 149 farmers reduced nitrogen use and only eight farmers increased after getting the SHC. Average reduction is $30 \mathrm{~kg} /$ acre (reduction ranged between 0 and $210 \mathrm{~kg}$ per hectare). Out of 157 farmers, 119 farmers decreased phosphorous use and only 38 farmers increased their phosphorus use after SHC. On average, farmers reduced phosphorus use by $11.8 \mathrm{~kg} / \mathrm{acre} .60$ farmers increased their potassium use after SHC, with an average increase of $12 \mathrm{~kg} / \mathrm{acre}$. About $50 \%$ of the farmers said SHC made them aware about soil health and helped them reduce the fertiliser use, which ultimately leads to decrease in the cost of cultivation. Out of 157 farmers, 143 farmers experienced increase in productivity after applying the recommended doses as per SHC information. Overall, after getting SHC, farmers have reduced $\mathrm{N}$, P, and $\mathrm{K}$ use, especially nitrogen and increased micro nutrients.

Table 44: Success stories of reduction in fertiliser use

\begin{tabular}{|c|c|c|c|c|c|c|c|c|c|c|c|c|c|c|c|c|c|c|c|c|}
\hline \multirow[t]{2}{*}{$\begin{array}{l}\text { Crop } \\
\text { cultivated }\end{array}$} & \multicolumn{4}{|c|}{ Before SHC (kg/ha) } & \multicolumn{4}{|c|}{ After SHC (kg/ha) } & \multicolumn{4}{|c|}{$\%$ change after $\mathrm{SHC}$} & \multirow[t]{2}{*}{$\begin{array}{c}\text { Production } \\
\text { Before SHC } \\
(\mathrm{kg} / \mathrm{ha})\end{array}$} & \multirow[t]{2}{*}{$\begin{array}{c}\text { increase in } \\
\text { production } \\
\text { (kg/ha) }\end{array}$} & \multicolumn{4}{|c|}{$\begin{array}{l}\text { Decreased in Value } \\
\text { (Rs/ha) }\end{array}$} & \multirow{2}{*}{$\begin{array}{c}\text { Incre } \\
\text { ased } \\
\text { produ } \\
\text { ction } \\
\text { value }\end{array}$} & \multirow[t]{2}{*}{$\begin{array}{c}\text { Total } \\
\text { gain } \\
\text { (Rs/ha) }\end{array}$} \\
\hline & $\mathrm{N}$ & $P$ & $\mathrm{~K}$ & MN & $\mathrm{N}$ & $P$ & $\mathrm{~K}$ & MN & $\mathrm{N}$ & $\mathrm{P}$ & $\mathrm{K}$ & $\mathrm{MN}$ & & & $\mathrm{N}$ & $\mathrm{P}$ & $\mathrm{K}$ & $\mathrm{MN}$ & & \\
\hline Cotton & 316 & 119 & 56 & 0 & 237 & 43 & 30 & 0 & -25 & -64 & -46 & 0 & 1850 & 300 & 632 & 1371 & 464 & 0 & 10500 & 12967 \\
\hline $\begin{array}{l}\text { Groun } \\
\text { dnut }\end{array}$ & 92 & 106 & 28 & 0 & 32 & 51 & 44 & 0 & -65 & -52 & 57 & 0 & 1680 & 466 & 478 & 992 & -287 & 0 & 16310 & 17493 \\
\hline Maize & 283 & 70 & 99 & 0 & 173 & 51 & 55 & 125 & -39 & -27 & -44 & 125 & 2750 & 863 & 883 & 340 & 784 & -1250 & 9493 & 10250 \\
\hline Paddy & 182 & 81 & 53 & 3 & 109 & 59 & 42 & 18 & -40 & -27 & -21 & 18 & 3280 & 1141 & 582 & 394 & 200 & -150 & 15974 & 17000 \\
\hline $\begin{array}{l}\text { Paddy, } \\
\text { gram }\end{array}$ & 20 & 14 & 2 & 10 & 12 & 6 & 2 & 10 & -40 & -57 & 0 & 10 & 3165 & 927 & 64 & 144 & 0 & 0 & 12978 & 13186 \\
\hline Ragi & 109 & 132 & 66 & 0 & 75 & 54 & 35 & 18 & -31 & -59 & -47 & 18 & 1940 & 1317 & 270 & 1402 & 558 & -180 & 15804 & 17855 \\
\hline $\begin{array}{l}\text { Soybean } \\
\text { gram }\end{array}$ & 28 & 73 & 16 & 0 & 46 & 111 & 13 & 0 & 64 & 52 & -19 & 0 & 1350 & 630 & -143 & -683 & 55 & 0 & 15750 & 14978 \\
\hline Sunflower & 119 & 79 & 0 & 0 & 96 & 62 & 0 & 0 & -19 & -22 & & 0 & 2030 & 1519 & 181 & 313 & 0 & 0 & 45570 & 46064 \\
\hline Total & 174 & 88 & 49 & 0 & 106 & 59 & 41 & 20 & -39 & -33 & -16 & 20 & 2268 & 1010 & 543 & 523 & 141 & -198 & 17797 & 18807 \\
\hline
\end{tabular}

Estimates from table 44 show that the gains from the practices of the recommended doses of fertilisers as per the SHC show that up to Rs.1,000 can be saved from the reduction in fertiliser expenditure per hectare, and major gain arises from the increase in yields due to adoption of balanced fertilisers to the extent of Rs.17, 000 per hectare. 


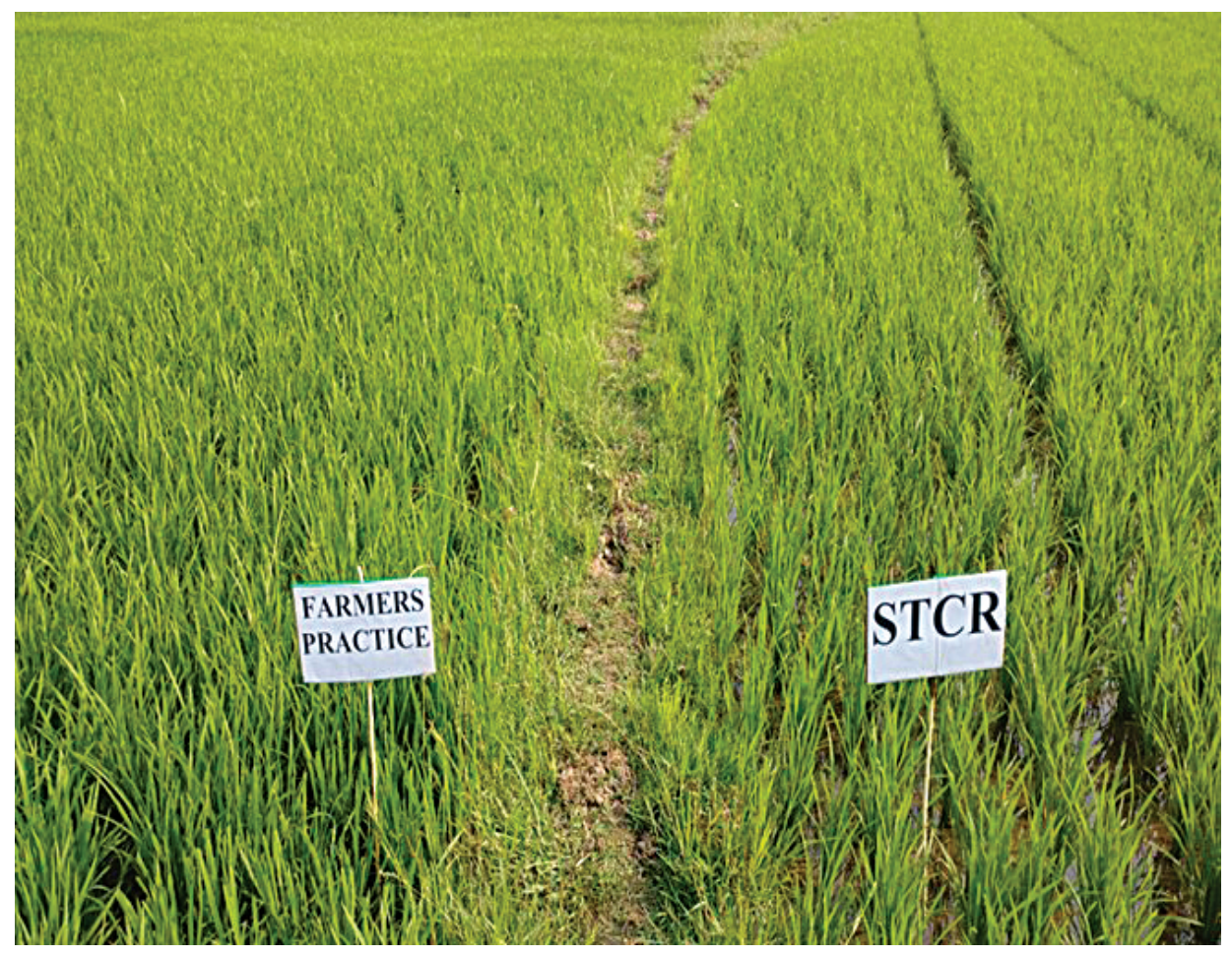

Fig. 19: Soil-test-crop-response-based fertiliser recommendation system

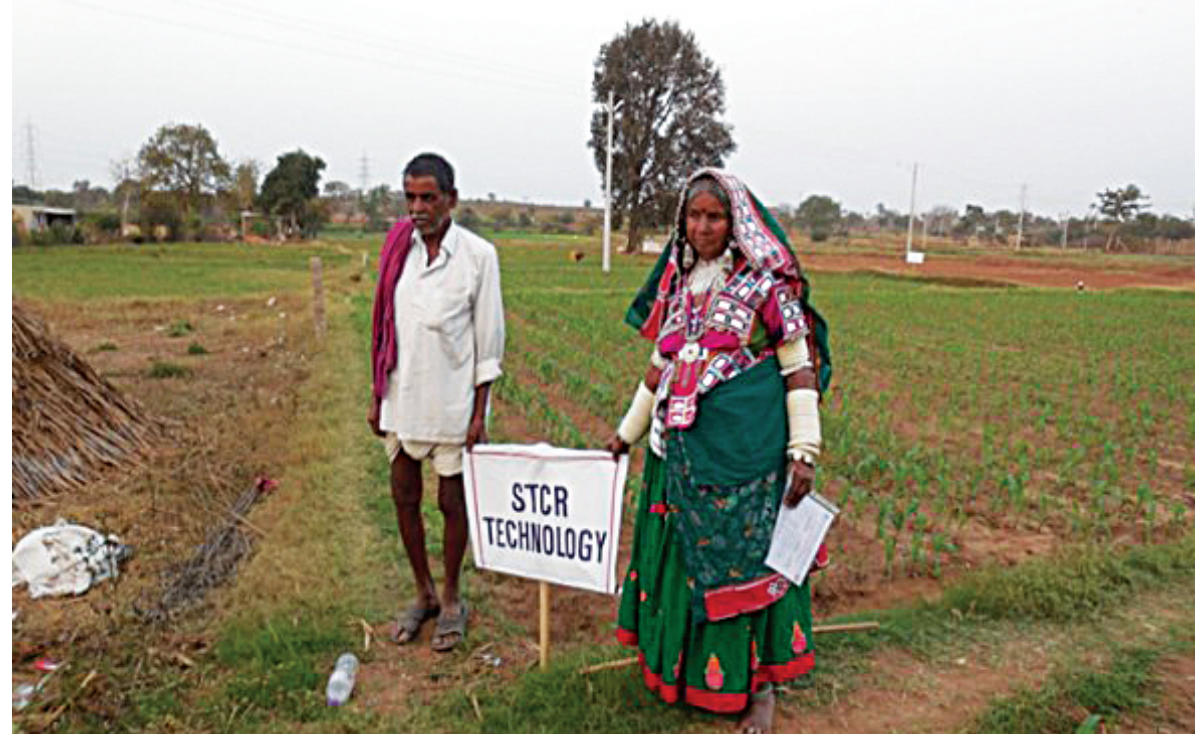

Figure 20: Soil-test-crop-response-based fertiliser recommendation system

\subsection{State-wise and crop-wise fertiliser consumption}

\section{State-wise consumption of fertilisers:}

As per the Commission for Agricultural Costs and Prices (CACP) data, there was a wide variation in fertiliser application among different states (Table 46). For example, in the case of cotton fertiliser, consumption was the highest in Maharashtra (256 kg/ha) and lowest in Madhya Pradesh (107 kg/ha). Similarly, in case of maize fertiliser, consumption was the highest in Andhra Pradesh $(244 \mathrm{~kg} / \mathrm{ha})$ and lowest in Chhattisgarh (only $21 \mathrm{~kg} / \mathrm{ha}$ ). In case of paddy, highest fertiliser use was in Karnataka (313 $\mathrm{kg} / \mathrm{ha})$ and lowest in Assam $(17 \mathrm{~kg} / \mathrm{ha})$. These types of anomalies can be eliminated through the adoption of SHCs, and this will also reduce regional yield gaps to a significant extent. 
Table 45: Analysis of fertiliser use by crop across states (CACP data) 2013

\begin{tabular}{|c|c|c|c|c|}
\hline Crop & State & $\begin{array}{l}\text { Yield } \\
\text { (qtl/ha) }\end{array}$ & $\begin{array}{l}\text { Fertiliser use } \\
\text { (kg/ha) }\end{array}$ & $\begin{array}{l}\text { Gross return } \\
\text { (Rs/ha) }\end{array}$ \\
\hline \multirow[t]{11}{*}{ Cotton } & Maharashtra & 19 & 256 & 86947 \\
\hline & AP & 17 & 221 & 70240 \\
\hline & Gujarat & 22 & 216 & 106209 \\
\hline & Punjab & 17 & 197 & 94563 \\
\hline & $\mathrm{TN}$ & 15 & 180 & 70542 \\
\hline & Odisha & 12 & 167 & 47586 \\
\hline & Karnataka & 15 & 158 & 74865 \\
\hline & Haryana & 16 & 139 & 85466 \\
\hline & Rajasthan & 20 & 114 & 105814 \\
\hline & MP & 17 & 107 & 79010 \\
\hline & Total & 19 & 201 & 90385 \\
\hline \multirow[t]{11}{*}{ Maize } & AP & 61 & 244 & 76205 \\
\hline & $\mathrm{TN}$ & 49 & 212 & 65552 \\
\hline & Karnataka & 40 & 206 & 50524 \\
\hline & Gujarat & 17 & 147 & 33291 \\
\hline & Rajasthan & 20 & 111 & 31409 \\
\hline & Bihar & 23 & 100 & 31992 \\
\hline & MP & 19 & 71 & 24940 \\
\hline & UP & 20 & 70 & 28512 \\
\hline & HP & 14 & 46 & 22486 \\
\hline & Chhattisgarh & 15 & 21 & 18356 \\
\hline & Total & 29 & 130 & 40194 \\
\hline \multirow[t]{19}{*}{ Paddy } & Karnataka & 57 & 313 & 93307 \\
\hline & $\mathrm{TN}$ & 51 & 235 & 77414 \\
\hline & AP & 54 & 230 & 79154 \\
\hline & Haryana & 48 & 209 & 124345 \\
\hline & Punjab & 58 & 199 & 97222 \\
\hline & Kerala & 47 & 176 & 97428 \\
\hline & Gujarat & 34 & 173 & 54250 \\
\hline & UP & 39 & 160 & 62707 \\
\hline & Uttarakhand & 41 & 157 & 59953 \\
\hline & WB & 42 & 141 & 60384 \\
\hline & Chhattisgarh & 31 & 131 & 42507 \\
\hline & MP & 34 & 114 & 61441 \\
\hline & Bihar & 25 & 106 & 32557 \\
\hline & Maharashtra & 31 & 102 & 53874 \\
\hline & Odisha & 28 & 85 & 37616 \\
\hline & Jharkhand & 19 & 53 & 25634 \\
\hline & HP & 24 & 30 & 43420 \\
\hline & Assam & 30 & 17 & 34753 \\
\hline & Total & 38 & 138 & 58543 \\
\hline
\end{tabular}




\begin{tabular}{|c|c|c|c|c|}
\hline \multirow[t]{8}{*}{ Sugarcane } & Maharashtra & 1072 & 665 & 244612 \\
\hline & $\mathrm{TN}$ & 951 & 415 & 237486 \\
\hline & Karnataka & 848 & 383 & 180535 \\
\hline & Haryana & 572 & 263 & 175556 \\
\hline & UP & 497 & 202 & 140784 \\
\hline & AP & 723 & 180 & 168031 \\
\hline & Uttarakhand & 463 & 149 & 127016 \\
\hline & Total & 814 & 418 & 199182 \\
\hline \multirow[t]{14}{*}{ Wheat } & Punjab & 49 & 242 & 76828 \\
\hline & Haryana & 46 & 205 & 82292 \\
\hline & WB & 32 & 191 & 46693 \\
\hline & Gujarat & 32 & 188 & 56414 \\
\hline & UP & 36 & 179 & 62352 \\
\hline & Maharashtra & 24 & 157 & 45308 \\
\hline & Uttarakhand & 28 & 154 & 51012 \\
\hline & Bihar & 27 & 144 & 49135 \\
\hline & Rajasthan & 41 & 127 & 78468 \\
\hline & Chhattisgarh & 16 & 123 & 24359 \\
\hline & Jharkhand & 23 & 114 & 38478 \\
\hline & MP & 32 & 108 & 54649 \\
\hline & HP & 16 & 57 & 31029 \\
\hline & Total & 34 & 161 & 59333 \\
\hline
\end{tabular}


Table 46: Fertiliser use (kg/ha) in 2014-15

\begin{tabular}{|c|c|c|c|c|c|c|c|}
\hline \multirow[t]{2}{*}{ State/Zone } & \multicolumn{4}{|c|}{ 2014-15 } & \multicolumn{3}{|c|}{ NPK ratio } \\
\hline & $\mathbf{N}$ & $\mathbf{P}$ & $\mathbf{K}$ & Total & $\mathbf{N}$ & $\mathbf{P}$ & $\mathbf{K}$ \\
\hline Pondicherry & 196 & 43 & 46 & 285 & 4.3 & 0.9 & 1 \\
\hline AP & 147 & 61 & 30 & 237 & 4.9 & 2.0 & 1 \\
\hline Telangana & 163 & 53 & 16 & 231 & 10.0 & 3.3 & 1 \\
\hline Karnataka & 96 & 48 & 32 & 176 & 3.0 & 1.5 & 1 \\
\hline $\mathrm{TN}$ & 97 & 36 & 31 & 164 & 3.2 & 1.2 & 1 \\
\hline Kerala & 20 & 8 & 12 & 41 & 1.7 & 0.7 & 1 \\
\hline A\&N Islands & 13 & 10 & 7 & 29 & 1.9 & 1.5 & 1 \\
\hline South Zone & 106 & 43 & 26 & 175 & 4.1 & 1.7 & 1 \\
\hline Gujarat & 96 & 28 & 9 & 133 & 10.6 & 3.1 & 1 \\
\hline Maharashtra & 69 & 34 & 23 & 126 & 3.0 & 1.5 & 1 \\
\hline Chhattisgarh & 57 & 27 & 9 & 92 & 6.6 & 3.1 & 1 \\
\hline MP & 49 & 26 & 3 & 78 & 15.5 & 8.4 & 1 \\
\hline Rajasthan & 40 & 14 & 1 & 55 & 62.5 & 21.7 & 1 \\
\hline West Zone & 59 & 25 & 9 & 93 & 6.7 & 2.9 & 1 \\
\hline Punjab & 179 & 43 & 5 & 227 & 36.0 & 8.7 & 1 \\
\hline Haryana & 172 & 43 & 6 & 221 & 28.0 & 7.0 & 1 \\
\hline Uttarakhand & 129 & 24 & 7 & 160 & 18.7 & 3.5 & 1 \\
\hline UP & 112 & 32 & 7 & 150 & 16.9 & 4.9 & 1 \\
\hline HP & 36 & 9 & 10 & 54 & 3.7 & 0.9 & 1 \\
\hline North Zone & 131 & 36 & 7 & 174 & 19.7 & 5.3 & 1 \\
\hline Bihar & 133 & 31 & 15 & 179 & 9.0 & 2.1 & 1 \\
\hline WB & 78 & 40 & 33 & 151 & 2.4 & 1.2 & 1 \\
\hline Odisha & 36 & 15 & 7 & 57 & 5.3 & 2.1 & 1 \\
\hline Jharkhand & 31 & 7 & 1 & 38 & 28.2 & 6.0 & 1 \\
\hline East Zone & 75 & 27 & 17 & 118 & 4.4 & 1.6 & 1 \\
\hline Assam & 68 & 22 & 35 & 125 & 1.9 & 0.6 & 1 \\
\hline Manipur & 45 & 9 & 8 & 62 & 5.7 & 1.1 & 1 \\
\hline Tripura & 18 & 14 & 8 & 41 & 2.2 & 1.7 & 1 \\
\hline Nagaland & 3 & 2 & 1 & 6 & 2.8 & 1.6 & 1 \\
\hline Meghalaya & & & & & & & \\
\hline Arunachal Pradesh & & & & & & & \\
\hline Mizoram & & & & & & & \\
\hline Sikkim & & & & & & & \\
\hline NE zone & 45 & 15 & 22 & 83 & 2.0 & 0.7 & 1 \\
\hline All-India & 85 & 31 & 13 & 128 & 6.7 & 2.4 & 1 \\
\hline
\end{tabular}

Source: Fertiliser Statistics 
The state-wise fertiliser use is given in table 46. It shows that fertiliser use per hectare was the highest in Puducherry (285 kg/ha), followed by Andhra Pradesh (237 kg/ha), Telangana (231 kg/ha), Karnataka (176 kg/ha), and Tamil Nadu (164 kg/ha). The NPK ratio was close to the recommended practice for states such as Pondicherry, Andhra Pradesh, Karnataka, Tamil Nadu, Himachal Pradesh, and Maharashtra. In general, NPK ratio for southern and eastern zones is closer to the recommendation. But in case of northern states, Jharkhand, Rajasthan, Punjab, Haryana, Uttarakhand, and Uttar Pradesh are much different from the recommended doses, and this needs to be changed. SHC-based recommendations will help in reducing these imbalances in fertiliser application, which will help soil health in turn. 


\section{Chapter VI \\ Policy Recommendations}

Soil health and fertility form the basis for sustainable profitability of the farmers. Using optimal doses of fertilisers and cropping pattern as per the scientific recommendation are the first step towards sustainable farming. Soil testing is a science-based and time-tested tool for assessment of soil fertility status and soil ailments and for nutrient amendment recommendations. Soil testing, as a tool for judicious fertiliser use, works on the principle of profitability, which means if all other factors of production are optimum and none of them are limiting, there is a probability of obtaining a more profitable response to applied nutrients based on soil testing than those applied on an ad hoc basis.

In India, the current consumption of NPK ratio is 6.7:2.4:1, which is highly skewed towards nitrogen as against the ideal ratio of 4:2:1. India spends nearly Rs. 70,000 crore on fertiliser subsidy every year. According to the estimates, subsidy amount is about Rs. 5,000/ha of net cropped area and about Rs. 5,100/farmer, resulting in excessive use of fertilisers, especially NPK, at the cost of micro nutrients and manure. Hence, there is a need for balanced use of fertilisers. Keeping this in mind, the Government of India introduced Soil Health Card Scheme across India (GoI, 2017).

On December 5, 2015, the Ministry of Agriculture introduced the Soil Health Card scheme. It was approved for implementation in the remaining period of 12 th plan. SHC will be provided to all farmers in the country at an interval of two years to enable the farmers to apply recommended doses of nutrients based on soil test values for improved and sustainable soil health and fertility, low costs, and higher profits.

Under the SHC scheme, cropped area was divided into grids of 10 ha for rainfed and 2.5 ha for irrigated. One soil sample from each grid was be taken, and the test results were to be distributed to all the farmers whose lands fell under the grid. Based on the grid system, of the total 14.1 crore hectare of net cropped area, 73 lakh grid samples were to be collected to cover 7.3 crore ha in rainfed areas and 2.7 crore grid samples were to be collected to cover 6.8 crore ha irrigated land. That is, a total of 3.46 crore grid samples in two years ( 1.73 crore grid samples per year) and an average of 25,000 grid samples per district/year or 29 grid samples per village/year. With this, all 10.39 crore farmers will be covered in two years. Every year, 5.2 crore farmers need to be covered.

Under cycle 1,2.54 crore samples were collected, 2.36 crore samples tested, 9.62 crore soil health cards printed, but only 9.33 crore SHCs distributed. This indicates that $100 \%$ target was archived in sample collection, $93 \%$ of the target was achieved in soil testing, but only $80 \%$ of the target was achieved in SHC printing. 97\% of the SHCs printed were distributed among the farmers as on September 24,2017. Cycle 2 has already started in many states. 


\section{Objectives of the Impact Study}

As the SHC scheme has completed more than 2 years of implementation, the ministry has initiated a nationwide impact assessment with the following objectives:

o To examine the design of the SHC scheme in terms of planning, implementation, inputs (staff, financial, and other resources), activities (trainings, lab established, and strengthened), outputs (SHCs printed and distributed to farmers).

o To assess the modalities of delivery of the SHC scheme regarding procurement, sample collection, testing, SHC printing, and disbursal.

o To assess the level of utilisation of SHCs by the farmers across farm size classes in irrigated and rainfed situations.

o To assess the impacts of the SHC scheme on judicious use of fertilisers, bio-fertilisers, organic fertilisers, soil health, cropping choice, cost reduction, farm profitability, and sustainability.

o To provide recommendations for improvement of the overall design of the programme.

\section{* Methodology}

Both quantitative and qualitative approaches were adopted to achieve the objectives of the study. Qualitative information was in the form of stakeholder interviews across the states under the study, expert opinion gathering at the national and state level workshops, and interactions with the progressive farmers and agricultural officers. At the quantitative level, both secondary and primary data was collected at the national, state, and farmer levels. Secondary data mostly pertains collection and analysis of financial and physical achievements of the SHC scheme over the years, infrastructure availability, coverage of SHCs across the states, etc. Besides, information at the international level was collected for some selected countries to see the best practices in the design of soil health cards.

The secondary data was analysed for all the states, while primary data was analysed for 16 states of India representing all agro-climatic zones. A systematic sample was drawn for the impact assessment at the farmer level. Care was taken to represent the whole country and its agro-climatic conditions. A structured questionnaire was canvassed among 3,184 sample farmers across 199 villages in 16 states. In addition, focus group discussions were conducted in each village to get feedback from the key informants, farmers not covered for individual surveys and farmers who had not received soil health card. All indicators collected from the field survey were classified as inputs (financial and physical inputs under the project), activities (different activities organised under the scheme), outputs (actual outputs of the project), outcomes (whether generated outputs were utilised by the farmers), and impacts (what are the ultimate benefits to the farmers); they're listed here. The analyses were carried out across zones/states and completed by the date of receiving SHC by the farmers, i.e., those who received SHC more than a year back and those who received it recently. This would help understand the long-term impacts as well as provide insights into whether agriculture development helps better awareness and demand for SHC. 


\section{Cost Concepts Used in Calculating the Net Returns and Returns over Variable Costs}

\section{Costs are generated through certain cost concepts.}

These cost concepts and the items of costs included under each concept are as follows:

Cost A1 (all paid out costs incurred by owner-cultivator):
i. Value of hired human labour
ii. Value of hired bullock labour
iii. Value of owned bullock labour
iv. Value of hired machinery labour
v. Hired machinery charges
vi. Value of seed (both farm produced and purchased)
vii. Value of insecticides and pesticides
viii. Value of manure (owned and purchased)
ix. Value of fertiliser
x. Depreciation on implements and farm buildings
xi. Irrigation charges
xii. Land revenue, cesses, and other taxes
xiii. Interest on working capital
xiv. Miscellaneous expenses (artisans etc.)

Cost A2: Cost A1+ rent paid for leased-in land

Cost B1: Cost A1+ interest on value of owned fixed capital assets(excluding land).

Cost B2: Cost B1+ rental value of owned land (net of land revenue) and rent paid for leased-in land

Cost $\mathrm{C} 1$ : Cost $\mathrm{B} 1+$ imputed value of family labour

Cost C2: Cost B2+ imputed value of family labour

Cost C2*: Cost $\mathrm{C} 2$ adjusted to take into account valuation of human labour at market rate or statutory minimum wage rate, whichever is higher.

Cost C3: $\quad \operatorname{Cost} \mathrm{C} 2 *+$ value of management input at $10 \%$ of total $\operatorname{cost}(\mathrm{C} 2 *)$.

In this study, only coast $\mathrm{A} 1$ and cost $\mathrm{C} 2$ were used to calculate returns over variable costs and net returns, respectively, by deducting costs from gross returns.

\section{Imputation Methods}

Some of the inputs used in the production process are provided by family sources. The criteria adopted for deriving imputed values of these inputs are as follows: 


\begin{tabular}{|c|c|c|}
\hline $\begin{array}{l}\text { Sl. } \\
\text { No. }\end{array}$ & Items & Criteria \\
\hline$(1)$ & (2) & (3) \\
\hline i. & Family Labour & $\begin{array}{l}\text { On the basis of statutory wage rate or the } \\
\text { actual market rate, whichever is higher }\end{array}$ \\
\hline ii. & Owned animal labour & $\begin{array}{l}\text { On the basis of cost of maintenance, which } \\
\text { includes cost of green and dry fodder and } \\
\text { concentrates, depreciation on animal and } \\
\text { cattle shed, upkeep labour charges and } \\
\text { other expenses. }\end{array}$ \\
\hline iii. & Owned machinery charges & $\begin{array}{l}\text { On the basis of cost of maintenance of farm } \\
\text { machinery, which includes diesel, } \\
\text { electricity, lubricants, depreciation, repairs } \\
\text { and other maintenance expenses. }\end{array}$ \\
\hline iv. & Implements & $\begin{array}{l}\text { Depreciation and charges on account of } \\
\text { minor repairs. }\end{array}$ \\
\hline $\mathrm{v}$. & Farm produced manure & Evaluated at rates prevailing in the village. \\
\hline vi. & Rent of owned land & $\begin{array}{l}\text { Estimated on the basis of prevailing rents } \\
\text { in the village for identical type of land or as } \\
\text { reported by the sample farmers subject to } \\
\text { the ceiling of fair rents given in the land } \\
\text { legislation of the concerned state. }\end{array}$ \\
\hline vii. & $\begin{array}{l}\text { Interest on onward fixed } \\
\text { capital }\end{array}$ & $\begin{array}{l}\text { Interest on present value of fixed assets } \\
\text { charged at the rate of } 10 \% \text { per annum. }\end{array}$ \\
\hline
\end{tabular}

\section{Allocation/Apportion of Joint Costs:}

The expenditure incurred on, or imputed for, some of the cost items relate to the farm as a whole. Such joint costs are allocated to individual enterprises, among different categories of livestock, and so on. Depreciation on farm buildings and implements, land rents, land revenue, cesses and taxes, interest on owned fixed capital are such costs that are allocated to each category of crops in proportion to their areas. The cost for livestock is allocated to each category of animals in proportion of their numbers to the total number of animals owned by the farmer.

The apportionment of total costs incurred jointly on different crops grown in mixture crops is done in proportion to the total value of output contributed by individual crops in the crop mixtures. The apportionment of total costs of cultivation between the main product and the by product(s) is done in proportion to their contribution to the total value of output. 


\section{* Results}

It should be noted that the analysis is based on the representative, though limited, sample size across regions. It is too short a time for the scheme (only two-years old) to carry out a full-fledged impact assessment. The present analysis provides insights about the direction and cautions about any shortcomings. While the following conclusions and recommendations are based on the analysis, the weakness of the assessment needs to be kept in mind.

$\checkmark$ Given the short duration of the scheme, awareness levels are good. At the same time, participation of farmers in meetings and exposure visits is not high. Awareness campaigns need to be organised on the content of SHCs, use of recommended practices, reduction in fertiliser use, and costs and increase in profitability.

$\checkmark$ There is no apparent or significant bias against socio-economically vulnerable sections. In contrast, small and marginal farmers benefit more in some cases.

$\checkmark$ There is some reduction in fertiliser use, especially nitrogen and increase in bio-fertilisers and other micro nutrients use. This is a good sign as the N: P: K ratio was highly skewed towards nitrogen. Costs were reduced due to low fertiliser use. Crop yields also increased for a majority of the crops, although only moderately.

$\checkmark$ A significant impact is the increase in the use of gypsum and other micro nutrients to some extent.

$\checkmark$ There is a need to strengthen the SHC-related extension services to provide better advisories.

$\checkmark$ Two-thirds of the sample farmers indicated that SHC is beneficial, which is encouraging given the short span of the programme.

$\checkmark$ The main complaint from the farmers is the timeliness of providing the results. This, however, is linked to the infrastructure (soil testing labs) and human resources. However, after the introduction of the SHC scheme, the time lag has significantly reduced. Results needs to be disseminated before the sowing season so that farmers will practice the recommended crop choice and fertilisers.

$\checkmark$ It is important to address these issues to gain confidence of the farmers in adoption of the fertilisers as per the recommendations included in the SHC.

$\checkmark$ The scheme has poor backing from infrastructure and human resources, with significant gaps. Although some southern and western states performed better, in some states, even the allocated resources are not being spent or utilised due to lack of capacities. This should be of high priority in the immediate future.

$\checkmark$ Proactive regions seem to be better in this regard.

$\checkmark$ Lack of capacities with regard to skilled personnel and STLs affects the quality of services, which in turn affects the credibility of the scheme and needs immediate attention.

$\checkmark$ Results need to be provided in time so that farmers can benefit better.

\subsection{Soil Sampling(SHC Design)}

- There is a need to identify best practices in soil sample collection and testing by examining across countries and different state governments practices. There is also a need for coordination and cooperation. 
- The existing uniform grid of 10 ha for dry lands and 2.5 ha for irrigated lands does not take local soil variability into consideration. Grid size should be variable based on the soil variability index. It should be decided at least at the block level based on soil heterogeneity, fertility maps, cropping pattern, irrigation facilities, and remote sensing maps. If soil is more variable, grid size should be reduced, and vice versa. Sampling errors needs to be reduced by using variogram. There should be a separate cell to monitor and recommend grid size across the country. This will also reduce cost, money, and manpower and increase the relevance of recommendations to farmers. In order to gain credibility of the farmers, at least one sample from each farmer should be included where soil variability is high.

- Soil variograms need to be developed at each block level. Grid size can be determined based on the soil variability. Variogram gives information about the spatial pattern of continuous soil attributes. The variogram may be used as a critical input to decide required soil samples to be collected based on the soil variability index. More soil samples should be collected if the blocklevel soil variability index was high and vice versa. Variogram is a tool to investigate and quantify the spatial variability of soil properties. The geostatistical literature shows that the following soil quality indicators were found to be the most important for variogram analysis, which can also be considered by the ministry. The available data with Indian Institute of Soil Science, Satellite maps of remote sensing agency of ISRO, and Land use planning data can be used to estimate blocklevel soil variograms.

- The following soil indicators may be considered to construct block-level soil variograms: (1) Soil Colour, (2) Slop, (3) Sand (\%), (4) Silt (\%), (5) Clay (\%), (6) Nitrogen (N), (7) Phosphorus (P), (8) Potassium (K), (9)Organic Matter (OM), (10) Organic Carbon (OC), (11) pH, (12) Cation Exchange Capacity (CEC), (13) Electrical conductivity (EC), (14) C:N Ratio, Cropping Pattern. The ICAR-Indian Institute of Soil Science (IISC), Bhopal; ICAR-IISWCIndian Institute of Soil and Water Conservation, National Remote Sensing Agency (NRSA), Hyderabad; and land classification/atlas can be consulted for developing block-level soil variograms.

- Evidence shows that samples collected from $20 \%$ to $30 \%$ of the farmers in a village are enough to get reasonable soil quality for advising farmers, and hence there was no additional benefit in covering each grid of 10 ha in case of dry lands and 2.5 ha in case of irrigated land if the soil was fairly uniform. In some cases, only $20-30$ samples/500 ha are sufficient, as is evident from ICRISAT experiments. This, however, needs to be explained to the farmers so that they would take the SHC recommendations seriously. One needs to be mindful of the efforts and resources gone into ICRISAT experiments.

- Although grids in some states were predetermined in the mobile app (such as in Punjab), in other cases, the procedure that's followed in dividing the cultivated village land into grids is not known to many agricultural officers and needs to be widely disseminated for accurate sampling, and this should be mentioned in the guidelines. Interestingly, Punjab is adopting a GIS-tablet grid identification and GPS-based soil sample collection application, which seems to be working well and is likely to solve many field-level sample collection problems. This model should be adopted across all the states after an in-depth understanding (study) of the model. 
- High density soil maps need to be developed for increasing precision at the village level.

- Agricultural officers and agricultural extension officers need to be given appropriate training, transport, and easy-to-use sampling tools and incentives for scientific sample collection.

- Coordination of agricultural extension officers and farmers needs to be enhanced, and extension officers should make sure that most of the grid farmers, if not all, should be present at the time of soil sample collection. This will build farmers' confidence in the soil health cards.

- It was observed by the study team that in some of the block agricultural offices, soil samples were kept aside for many days and soils were exposed to moisture and weather. After soil sampling, drying should be done within 15-20 days, and grinding, machine sieving, and bottling should be done in time for proper test results. Sample test results should reach farmers before the sowing season. It might be a good idea to limit samples to the capacities. The target should be to provide more accurate results rather than coverage. This would create demand for soil testing once the credibility of the testing is established.

\subsection{Soil Health Indicators (SHC Design)}

- The whole chain of soil health-plant-health-human health should be taken into account, and there is a need for promotion of balanced application of soil (macro and micro) nutrients.

- Excess application of urea results in accumulation of nitrate in the soil, and water is becoming a huge environmental problem in India. Hence, water quality information needs to be included in the SHC.

- The soil health card is more focused on chemical nutrient indicators; among physical and biological properties, only soil colour is included. Some more physical properties, such as slop of the land etc. needs to be incorporated as well.

- Microbial activity and moisture retention activity are essential but missing in SHC. Although soil organic matter is indicated, many soil testing labs are not equipped with the latest tools to measure it.

- At least one or two physical and micro-biological indicators (such as soil texture, water holding capacity, water quality and bacterial content) need to be incorporated. Soil health index needs to be developed and incorporated into SHC, which indicates the overall health of the soil.

- Although the basic structure of SHC should be uniform, states should adopt/change as per their agro-climatic zones and needs. Some of the indicators that need to be included in SHC are (i) cropping history, (ii) water resources (soil moisture), (iii) slope of soil, (iv) depth of soil, (v) colour of soil, (vi) soil texture (bulk density), and (vii) micro-biological activity. 


\subsection{Soil Testing Infrastructure}

- About 1,454 labs exist in India, of which only 700 are equipped with micro nutrient testing facilities. Although agricultural departments procured about 7,000 mobile kits recently, they are not as good as full-fledged labs. Very few labs could take up micro nutrient analysis. They are neither equipped with skilled personnel nor chemicals or functional equipment. The infrastructure is grossly inadequate by any standard, given that 11 crore farmers need to be covered.

- Under the current PPP model, investments in labs are to be done by private companies with an element of subsidy. A competitive bidding process based on technical and financial bids needs to be announced, and companies that quote reasonable cost (per sample) should be selected. The government will pay on a per-sample basis with the condition that they employ qualified and trained chemists. This model will be successful when there is no strong government presence in soil testing. However, the quality of such reports should got checked at random by authentic agencies.

- About $45 \%$ of the sample farmers are inclined to go to private STLs. At the same time, only $20 \%$ of the farmers are willing to pay for the services. Hence, one must find ways to support farmers in this regard, i.e., direct subsidy to the farmers or private STLs, etc. A competitive PPP model could be explored in this regard, while the government should take up the monitoring of the functioning of these labs more seriously. At the same time, there should be special incentive for Farmer Produce Companies (FPCs) to establish soil testing labs. There is a need for encouraging competition among private companies in setting up and running the soil testing labs so that they maintain quality at a reasonable cost. Institutional modalities could be worked out regarding how to equip and manage STL within the FPCs framework.

- Some of the private soil testing labs indicated that the cost of sample collection and testing was up to Rs. 1,000/sample. Some private companies are charging Rs. 75/element; accordingly, for 12 elements, the total cost will be Rs. 900/sample. The government should be more realistic in fixing the prices for private parties. It should focus more on the quality of services at an acceptable (market) cost.

- There should be strengthening and upgrading of at least one soil testing lab per district as a stateof-the-art lab, equipped with world class infrastructure and accredited by internationally recognised agencies either in the public or the private sector. So, nearly 700 state-of-the-art labs are needed to act as referral labs and to give broad advice to farmers. The cost per unit will be about Rs. 4-5 crore/unit, with a total of Rs. 2,800 crore. However, if this resulted in Rs. 1,000/ha savings in fertiliser use even if we don't consider the yield increase resulting in a saving of Rs. 14,500 crore in a year for the economy. This could be a more worthwhile investment than spending money and providing services that have little value to farmers year after year, i.e., spending more in the long run.

- State-of-the-art district-level soil testing labs at a direct level should be equipped with Inductively Coupled Plasma Atomic Emission Spectrometry (ICP-AES), which costs about Rs. 
40-50 lakh. These labs should have a 24-hour generator for uninterrupted power supply, computer labs with colour printing facility, and air conditioned laboratories. In addition, the lab should have the following equipment for conducting soil testing on a large scale:

o KEL PLUS automatic nitrogen determination distiller

o Automated Flame Photometer (for Potassium)

o Automated Spectrophotometer (for Phosphorus)

o Atomic Absorption Spectrophotometer (for $\mathrm{Zn}, \mathrm{Fe}, \mathrm{Mn}, \mathrm{Cu}$ )

o Water distillation still (20 lit/hour)

o All glass distillation unit (5 litre/hour)

o Auto analyser (N\&P)

o Automated $\mathrm{pH}$ meter

o Automated EC meter

o Centrifuge

- Some soil scientists and agricultural officers are of the opinion that test results of mini kits (mini labs) are not as accurate enough as those of full-fledged labs. Mini kits need to be standardised and tested for errors in calibrations. A mini kit costs about Rs. 94,800. With this, the per-sample cost comes about Rs. 170-200. A mini kit is useful for remote villages and tribal communities and should also be used to measure highly volatile elements such as Nitrogen, which needs more frequent measurement. Some block agricultural offices received five-six mini kits, but they were not able to utilise them as they are involved in multiple activities.

- Soil testing is a specialised and highly skill-oriented job. Frequent transfers of soil testing staff adversely affect the skill development within labs as well as the test results. There is a need to build some permanent staff in the labs who are interested and specialised in soil testing. Field observations indicate that only female officers are interested in working with soil testing labs.

- Management of state-of-the-art soil testing labs could be established under the purview of FPC's federations or nodal FPCs at the district level. The governance responsibilities should be handed over to them to be run them as business models. The back of the envelop indicates that establishing a state-of-the-art lab with a Rs. 6 crore loan from NABARD in each district looks viable given that an average of 25,000 samples need to be collected and processed per year. At Rs. 1,500-2,000 per sample (at half the market price for a detailed soil analysis), the investments will be paid back in less than 2 years. The state department can have a monitoring cell created especially for this purpose, and extension services need to gear up to deal with soil health advisories. FPCs should be encouraged to set up demonstration plots.

\subsection{Soil Extension}

- SHC recommendations should be accompanied by block-level recommendations. There should be an intermediate solution (based on both village-level soil maps and SHC recommendations) to be able to reach the farmer's level. 
- There is a need for demonstration of SHC benefits on an experimental basis in each block by adopting a comprehensive approach (systematic and scientific analysis of soil and water) and recommended doses. This would have much greater impact than subsidised and less authentic information. General SHG schemes and model farm initiatives should go together.

- In many villages, agricultural officers are distributing SHCs in awareness campaigns through village presidents and mandals/blocks' democratically elected representatives. However, in some villages, the village revenue assistant distributes SHC and takes signatures without explaining the content. Whenever SHC is distributed in awareness campaigns and meetings directly, a greater number of farmers feel that they are convinced to use recommended practices. There is a need to follow standard protocol to inform farmers about the recommendations of the SHC when it is handed over to farmers.

- A specialised body is needed both at the central as well as the state level for the management of soils. They should be given the responsibility of monitoring the quality of service by various agencies. This also provides continuity in the workings of the department.

- Development of GIS-based soil fertility maps at the village/block level and wider publicity through wall posters and display boards in village panchayats should be promoted. Advertisements, slogans, etc. should be developed in local languages to increase awareness. This should be taken up in a campaign mode, i.e., on the lines of the anti-smoking/tobacco campaign.

- Many farmers are not aware of the SHC portal. The SHC portal should be more farmer-friendly and simplified. A professional body may be employed to design the portal in more farmerfriendly and effective manner.

- A simple tool to assess the quantity of urea, DAP, and MoP based on SHC needs to be displayed as wall posters in the villages.

- It should be mandatory to enter fertiliser purchases by the farmers on the soil health card by each fertiliser dealer along with the signature. This will not only increase awareness, but will also help in adoption as per the recommendation.

\subsection{Policy-related}

- If the SHC programme is to be successful, the high fertiliser subsidy for NPK needs to be reduced. Prices should reflect true cost to the economy; only then will farmers have incentives to use fertilisers judiciously according to the recommendations of the SHC. On the contrary, subsidy on micro nutrients should be increased. However, the quality of micro nutrients supplied on a subsidy basis in some states is highly doubtful.

- The government should set up state-of-the-art labs to test the quality of micro nutrients supplied. Accreditation of such labs to national/international standard institutes should be initiated as well. Supply of phosphorous soluble bacteria should be mandatory along with phosphate fertilisers and 
rock phosphate-like neem-coated urea. FPCs need to be encouraged to take up the SHC scheme as a business model by setting up state-of-the-art labs at the district level. Since FPCs are already involved in selling fertilisers, they are in a better position to stock all the required (according to SHC recommendations) fertiliser and micro-nutrient compositions and supply them to individual FPCs across the district.

- State-of-the-art district-level soil testing labs should be equipped with Inductively Coupled Plasma Atomic Emission Spectrometry (ICP-AES), which costs about Rs. 40-50 lakh. These labs should have a 24-hour generator for uninterrupted power supply, computer labs with colour printing facility, and air conditioned laboratories. In addition, the lab should have the following equipment for conducting soil testing on a large scale:

o KEL PLUS automatic nitrogen determination distiller

o Automated Flame Photometer (for Potassium)

o Automated Spectrophotometer (for phosphorus)

o Atomic Absorption Spectrophotometer (for $\mathrm{Zn}, \mathrm{Fe}, \mathrm{Mn}, \mathrm{Cu}$ )

o Water distillation still (20 lit/hour)

o All glass distillation unit (5 litre/hour)

o Auto-analyser (N\&P)

o Automated $\mathrm{Ph}$ meter

o Automated EC meter

o Centrifuge

- There should be some incentives/awards for the farmers who grow green manure and vermicompost and whose soil fertility increased over the years based on Soil Health Card.

- Some incentives should be provided to local bodies that encourage good practices such as recycling crop residues, encouraging common lands for corporates, etc.

- Similarly, incentives can be given to villages when they adopt crop rotation with legumes.

- Innovative techniques such as neem-coated urea (for slow release of fertiliser into the soil) need to be promoted by the government. There should be $45 \mathrm{~kg}$ urea bags instead of $50 \mathrm{~kg}$ ones, which will reduce the loss/excessive use of fertilisers by about $10-20 \%$, especially by small and marginal farmers.

- Soil sample collection, testing, and printing at the district level is significantly positively influenced by fertiliser use, number of bank accounts, net sown area, number of soil testing labs, and households with mobiles.

- Other policies, such as water exploitation, electricity, etc., should be in line so that crop diversity that can protect soil health in the long run. 


\section{$\underline{\text { References }}$}

1. GoI (2016); Desertification and Land Degradation Atlas of India (Based on IRS AWiFS data of 2011-13 and 2003-05); Space Applications Centre Indian Space Research Organisation Department of Space, Government of India, Ahmedabad, June.

http://www.indiaenvironmentportal.org.in/files/file/Desertification_Atlas_2016.pdf

2. Reddy, B. Suresh. "Dynamics of soil fertility management practices in semi-arid regions: a case study of AP." Economic and Political Weekly (2011): 56-63.

3. Fishman, R., Kishore, A., Rothler, Y. and Ward, P., 2016. Can Information Help Reduce Imbalanced Application of Fertilisers in India? Experimental Evidence from Bihar (No. 235705). Agricultural and Applied Economics Association.

4. Chander, G., Wani, S.P., Sahrawat, K.L., Dixit, S., Venkateswarlu, B., Rajesh, C., Rao, P.N. and Pardhasaradhi, G., 2014. Soil test-based nutrient balancing improved crop productivity and rural livelihoods: case study from rainfed semi-arid tropics in Andhra Pradesh, India. Archives of Agronomy and Soil Science, 60(8), pp.1051-1066.

5. Raju, K.V., Gaur, A. and Wani, S.P., 2015. Poverty reduction approach in South Asia: Rejuvenating centuries old water bodies to improve rural livelihoods, A case of Karnataka state, India.

6. Rajashekar (2011) India's Soil Crisis, The Economic Times Mumbai; Date: Jul 12, 2011.

7. Reddy V. Ratna (2003); "Land Degradation in India: Extents, Costs and Determinants”, Economic and Political Weekly, Vol. XXXVIII, No. 44, November 1-7, 2003 
Feedback from agricultural officers on status of soil health card and improvement needed

Questions

\section{Status of soil health card scheme}

Status of procurement of maps (patawari maps), Majority of officers mentioned that they don't field instruments (GPS), and deployment of have patawari maps; instead, they use remote staff for collection of samples from farmers' fields sensing data. They use the GPS system on their mobile and face shortage of manpower and funds.

Is the methodology of soil sample collection (10 ha grid for rained and 2.5 for irrigated) adequate?

Only nine officers said sampling methodology is adequate. Others said it is okay for homogenous land but inadequate in a majority of cases because of variability, topography, and because 10 ha is too big for precise analysis.

Quality of almost all labs is poor. Many of them are capable of measuring only NPK, not micronutrients. Most of them are outdated and face shortage of expert manpower.

16 officers said laboratory infrastructure is good.

Availability of colour Photostat machine, standard paper for printing, printing machines, and mechanism for distribution of soil health cards to farmers

Release of funds, time lags between release of funds to actual utilisation

SHC portal usefulness to farmers: rating from 1 to 5

All officers said portal is useful but farmers are not aware of it and they don't have required facilities.

Overall targets versus achievements as per the annual action plan

23 officers said they achieved their annual targets but faced manpower shortage.

\section{Soil health management (indicators)}

Number of AEOs/TOTs trained under the scheme
Very few out of the total district-level officers are trained.

20 officers said there is at least one good lab at the district level but its capacity is low, and hence there is a need for more labs. 


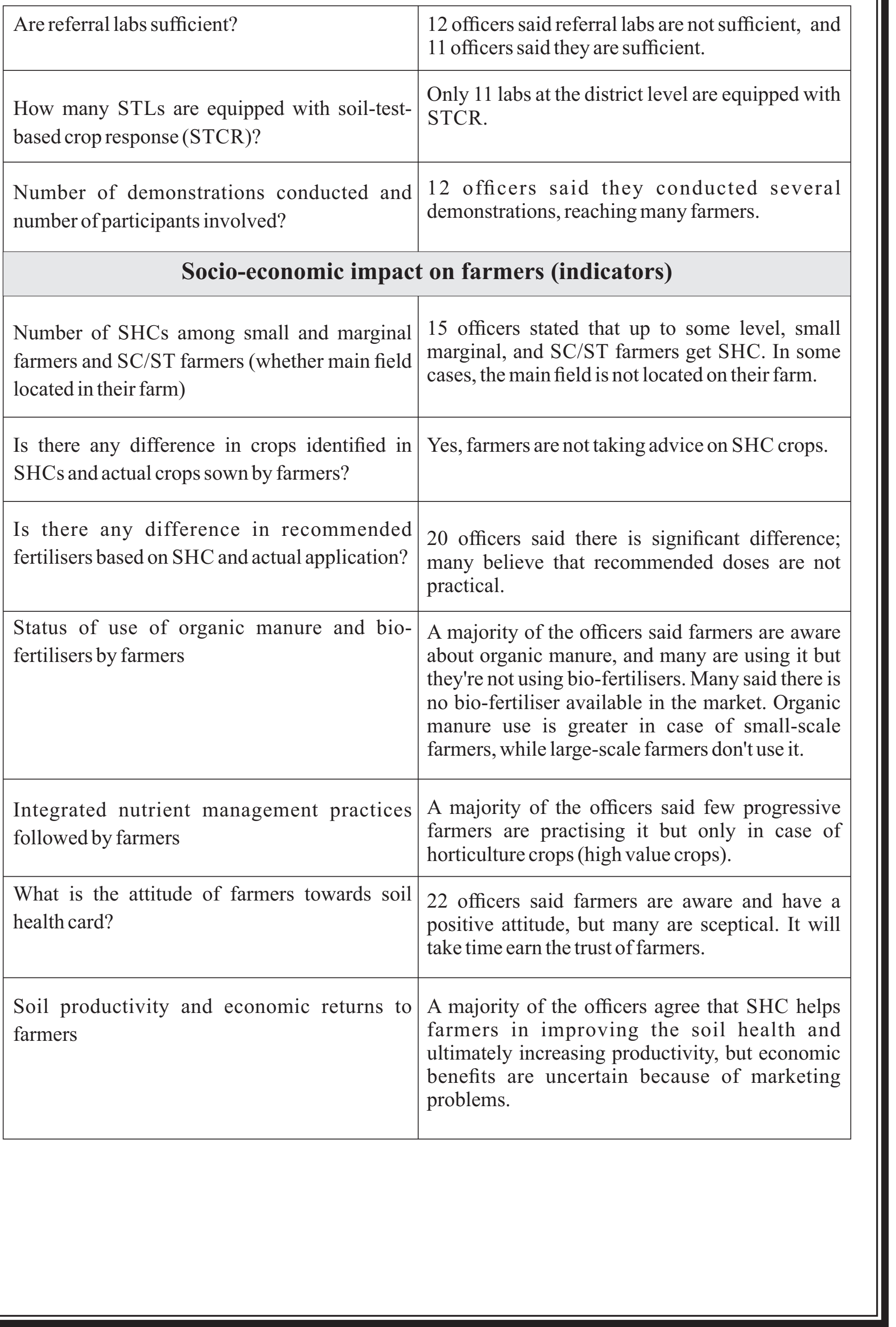


Annexure - 2

\section{Soil Health and Soil Testing: Some Practical Issues (Expert Opinions)}

Soil testing is a science-based and time-tested tool for assessment of soil fertility status and soil ailments and nutrient and amendment recommendations. Soil testing as a tool for judicious fertiliser use works on the principle of profitability, which means if all other factors of productivity are optimum and none of them are limiting, there is a high probability to obtain a more profitable response to applied nutrients based on soil testing than those applied on an ad hoc basis. Unfortunately, soil testing in India continues to be a government-driven programme rather than a farmer-driven one. The number of STLs is inadequate vis-à-vis the number of operational holdings, but it is equally true that the demand for soil testing is extremely low. Farmers do not opt for soil testing as a basis for their fertiliser use decisions.

In my opinion, the qualification peaks developed by ASCI hold true when you have a large number of private soil testing laboratories that are self-financed and can gain sufficient income. Unfortunately, the soil testing and soil health care issue is a skill development activity with little income generation. It serves as a decision tool for making fertiliser recommendations.

One of the reasons for the failure of soil testing in making a breakthrough year all these be grouped as follows:

1. Lack of awareness among the farmers

2. Soil sampling techniques being followed

3. Inordinate delay in the analysis of soil samples; sometimes, the results are given 3-4 months after the sample is analysed.

4. Lack of proper laboratory facilities, including frequent power breakdown, availability of chemicals, glassware, water facilities, upkeep of instruments and equipment.

In this context, the ASCI has suggested training for three QPS, namely:

- Soil samplers/collectors

- Soil and water testing lab analysts

- Soil and water testing lab assistants

5. It is worth mentioning that the soil sample collection work is normally taken up during the months of May-June of every year, i.e., 1-2 months in a year, and the rest of the time, the soil samplers do not have any work. Once the sample is collected, where should the sample be sent? Who has to carry out the analysis? Where are the laboratory facilities? Who are the people to man these laboratories? What are the standard procedures being followed? Do we have standard practical manuals for use in STLs?

6. Unfortunately, soil testing is a government driven initiative in India with very little farmer participation.

Some of the reasons behind the failure of STLs indicate that lack of qualification and manpower capability in STC is a major constraint as most of the staff in STL is not qualified and not competent enough to do the analysis. 
Another major constraint is the lack of or weak linkage between Dept. of Agricultural and other research organisations such as SAUs, NGOs, etc.

- As per critical analysis, lack of qualified and capable manpower in STL is the major constraint as most of the STL staff is not qualified and not competent enough to perform analysis.

- Training support from research organisations for STL personnel is at a poor level. Consequently, the scientific fertiliser recommendations don't get transferred from SAU and research organisations to extension agencies.

- Lack of knowledge about improved analytical methods, lack of latest and sophisticated equipment, inadequate and lack of automation are the major technical and financial constraints.

- Lack of computers and adequate software in STL also results in non-optimal utilisation of STL capacity.

- To focus on soil testing, there needs to be a separate directorate on soil testing at the state level on the lines of Dept. of Agriculture.

- There is need to appoint a continuous monitoring committee on soil testing at the state, district, mandal level. The monitoring committee at the state level may involve Dept. of Agriculture, SAU, fertiliser firms, and farmer representatives.

- Qualified and capable personnel should be appointed.

- Capacity building should be provided through practical methods to all the staff involved in soil testing up to the grassroot level, which includes the method of sampling, laboratory methodology, and interpretation of STCR recommendations for a reasonable period.

- Cross-checking of soil sample analysis should be done at the central laboratory.

- High targets should be reduced and be made reasonable

- Anominal fee should be charged instead of free-of-cost soil sample analysis.

- Farmer awareness and training programs on representative soil sample collection and analysis and application of fertilisers as per STCR technology should be organised as well. A few select farmers from each mandal may be sent to other research organisations such as IISS, Bhopal, to learn about the latest technology.

- Motivation techniques for soil testing personnel, such as performance-based promotions, special increments, exposure visits, deputation for related seminars, and workshops should be followed as well.

- Publicity programmes should be conducted on soil testing and information should be sent through pamphlets, newspapers, mass media, even up to the village level, along with fertility status maps and recommendations.

- Financial powers such as contingency amount to a minimal extent to the in-charge of soil testing should meet day-to-day constraints at the laboratory level.

- Soil testing should be made a central subject.

- Soil testing programmes should be brought administratively under the Dept. of Agriculture and technically under the State Agriculture University.

- Transfer of STL staff must be from one lab to the other lab but not to other depts. No additional unrelated works should be assigned to them, such as election duty, etc. 


\section{Efficiency Factors}

- Collection of soil samples will be done mostly in the summer season, when there is no crop.

- Thousands of samples will reach laboratories for analysis during that period.

- A minimum of 30-35 samples a day (all parameters included) could be a possible target.

- Running the labs at 10,000 samples/year capacity would need very efficient, effective systems and processes in place for $100 \%$ capacity utilisation.

- Time saving without compromising on quality and reliability is a challenge.

\section{Practical Issues and Steps to Improve the Facilities}

- Most of the laboratories in India are still adopting single extractants for individual estimation of nutrients, such as $\mathrm{P}, \mathrm{K}$, and $\mathrm{S}$, etc.

- There is no problem with them, but they consume more time and resources and strain the workers a lot.

- Availability of qualified passionate and dedicated manpower to work in labs is a challenge.

- Manpower with specific qualification, aptitude, and passion should be allotted this job to obtain desirable results.

- They should be trained often to enhance operational efficiency.

- Operations should be incentivised, building motivation and enhancing work efficiency.

- There is inconsistent power supply and unfavourable working environment in rural and semiurban areas where most of the laboratories are situated.

- In order to have uninterrupted operations, alternative power sources such as generator and battery backup will be useful.

- Adopt those instruments that can work with a chargeable battery as well as power sources.

- Instruments shall be more rugged, reliable, and be able to perform under abnormal working conditions.

- Use of semi-automatic/manually operable equipment (which can be serviced locally, with reduced power dependency) is a more practical option than using fully automated equipment that will have no control over the operator.

- Induction of a new system is important.

- There is a need to update recommendations with the current knowledge based on sound agronomic and research. There should also be a Decision Support System (DSS). Models shall be widely used to make appropriate fertiliser recommendations.

- Networking and frequent upgradation of soil test information in the public domain will help implement new ways and means of fertilisation practices and site-specific nutrient management options on a large scale.

- Delays in reporting of test scale.

- Automation in operation from sample registrations to test results data entry until generation of test reports will save considerable time for routine operations.

- It's great that some states have implemented online or web-based report generations.

- There should be linking of soil health cards and the issue of soil passbooks, linking them to fertiliser subsides, green manure seeds, organic manure. Only the fertilisers needed for field crops should be provided, and excess use of fertilisers should be avoided. 
In order to make soil testing a viable tool for sustainable productivity, the following may be attempted:

- Soil testing is a great tool to assess soil fertility and nutrient supplying capacity

- Timely reporting of soil test results to farmers is crucial in the whole programme.

- Speed and reliability of the operation is the most important.

- Appropriate systems and processes should be in place to effectively implement the programme to get desired results.

Instead of planning the training for soil samplers/collectors, soil and water testing lab analysis, and soil and water testing lab assistants, an alternative suggestion could be that since most of the states offer a two-year diploma in agriculture, such training may be given to these diploma holders, as they already have a preliminary idea about the subject and its importance. During the slack season, their services could be utilised for other agriculture-related activities. Furthermore, in many states, there are VDOs/AEOs (below the rank of AOs) who could drafted the soil and water analysis and the AOs could be trained on advanced aspects such as GPS, induction systems, soil health cards, fertiliser recommendations, etc., as their services could be utilised in a more efficient way. 


\section{Field Observations (Compiled across States)}

- In some states, the progress is not satisfactory.

- A majority of AEOs and farmers do not have awareness about the process of collection of soil in the fields.

- A majority of farmers did not get SHCs even six months after sample collection as there was a shortage of soil testing laboratories at the local/district level.

- In most cases, farmers were not involved in the collection of the soil samples and their fields were often not covered. Hence, farmers did not take this seriously.

- Farmers expressed that they have more than two parcels of land with varied soil quality but samples were taken from one parcel only. SHC based on one parcel is not suitable to another parcel of land.

- They wanted to take soil samples from each plot.

- Some farmers did not have awareness about the utility of SHC results and lost their cards.

- Even AO/AEO did not explain the content and use of SHCs to a majority of farmers while distributing them.

- Some farmers said that even AEOs were not too aware about the results and need sensitisation about the scheme for proper dissemination of knowledge related to SHC.

- Some illiterate and marginal farmers said that AEOs did not contact them and met only big and progressive farmers.

- Progressive farmers or big farmers followed the recommendations of SHC.

- In most mandals, micro nutrients in the soil are very poor. Marginal and small farmers were unable to adapt these practices due to high cost and also non-availability of nutrients. Only some big farmers are able to use them.

- Some farmers did not follow SHC recommendations because (i) they don't understand the content, (ii) they are costly, (iii) non-availability, (iv) they believe in high doses of fertilisers, (v) they followed traditional application of fertilisers.

- Sensitisation meetings, trainings, distribution of SHCs through elected representatives and follow-ups by the agriculture department are factors that help increase the utility of SHC.

- Farmers expressed that results of soil sample were given for a specific crop. Hence, they could not understand the application of fertilisers for the rest of the crops. SHCs also did not mentioning the alternative cropping pattern suitable for the local conditions.

- Farmers were not convinced about the soil test because earlier, the agriculture department took soil samples four to five times from some of the farmers, but results were not communicated even after 2-3 years. They got SHC only from this scheme.

- Farmers feel that if they follow SHC recommendations, they face some problems. For example, as per SHC, in tribal areas, if they use more 'N', crop would be attacked by more pests and diseases. Although some farmers adopted the recommended doses of fertilisers, they went back to their traditional methods.

- Some farmers got (one-two farmers for GP) soil tests from NGOs, private fertiliser companies, and KVKs etc. from 2008 to 2013. KVKs and private labs charged for this, but they explained the content to farmers, and most of the farmers practised the recommendations promptly. 
- Overall, some farmers reduce fertiliser application by getting advice from progressive, largescale, or educated farmers.

- After soil test, a majority of the farmers started using micro nutrients that they were not aware of earlier.

\section{Study Limitations}

- GPS not captured in some villages.

- In Telangana, new AEOs were appointed in February, 2017. So, they were unable to mobilise farmers who got SHC last year.

- In some mandals/villages, SHCs were not distributed to farmers due to shortage of soil testing labs.

\section{Recommendations:}

- This scheme is very useful for farmers. Some constraints and gaps were observed in implementing the scheme.

- Farmers need to be made aware about SHC and its results, importance, etc.

- To build capacity of AOs or AEOs for promotion of fertiliser/nutrient management practices,

- More meetings and trainings are needed for farmers and follow-ups are necessary for the success of the scheme.

- Separate staff is required for SHC to more efficiently promote recommendations to all farmers.

- Establishment of state-of-the-art labs in all district headquarters with large capacities to meet the target for districts is the need of the hour. Mini labs need to be further upgraded for accuracy and speed.

- Micro nutrients may be provided at subsidised prices to the farmers for 2-3 years

- AEOs are not able to actively participate in the SHC scheme as they have multiple tasks and are under pressure

- KVKs, SAUs, ICAR institutions, and private companies should participate in the programme by involving educated local youth in soil sample collection, testing, and distribution. 


\section{Review of Recent Studies}

\begin{tabular}{|l|l|l|l|l|}
\hline No & Reference & Context & Methodology & Analysis \\
\hline
\end{tabular}

1 Can information help reduce imbalanced use of fertilisers in India?

Evidence from Bihar

\begin{tabular}{|c|c|c|c|}
\hline $\begin{array}{l}\text { Ram Fishman, } \\
\text { Avinash } \\
\text { Kishore, Yoav } \\
\text { Rothler, Patrick } \\
\text { S. Ward, } \\
\text { Shankar Jha, } \\
\text { R. K. P. Singh. }\end{array}$ & $\begin{array}{l}\text { Three districts } \\
\text { from Bihar. } \\
\text { Period of study: } \\
\text { April } 2014\end{array}$ & $\begin{array}{l}\text { Samples from } 509 \\
\text { households (treatment) } \\
\text { and } 294 \text { households } \\
\text { (controlled) were } \\
\text { collected. } \\
\text { A simplified becker- } \\
\text { degroot-marschak } \\
\text { method was used to } \\
\text { calculate the WTP of } \\
\text { farmers for zinc } \\
\text { deficiency. }\end{array}$ & $\begin{array}{l}\text { Data from sample fields } \\
\text { shows that the gap } \\
\text { between recommended } \\
\text { fertiliser application and } \\
\text { actual application is huge } \\
\text { and especially big in the } \\
\text { case of urea. The main } \\
\text { reasons for farmers } \\
\text { i g n o } \mathrm{r} \text { a } \mathrm{n} \text { c e o f } \\
\text { recommendations of soil } \\
\text { health card were as follows: } \\
\text { 1. F a r m e } \mathrm{s} \text { i d n ' } \mathrm{t} \\
\text { understand the contents of } \\
\text { the SHC } \\
\text { 2. Farmers didn't find the } \\
\text { soil analysis and fertiliser } \\
\text { recommendations to be } \\
\text { reliable or compelling. } \\
\text { 3. Other factors such as } \\
\text { cost, liquidity, or timely } \\
\text { availability of specific } \\
\text { fertilisers were constraints. }\end{array}$ \\
\hline
\end{tabular}




\begin{tabular}{|l|l|l|l|l|}
\hline No & Reference & Context & Methodology & Analysis \\
\hline
\end{tabular}

2 Soil health mapping and direct benefit: transfer of fertiliser subsidy

\begin{tabular}{|c|c|c|}
\hline $\begin{array}{l}\text { ICRISAT } \\
\text { research report } \\
\text { IDC-6 }\end{array}$ & $\begin{array}{l}\text { Authors collected } \\
\text { data from various } \\
\text { government } \\
\text { authorities and } \\
\text { ground-level farm } \\
\text { results after } \\
\text { implementation of } \\
\text { the bhoomichetana } \\
\text { project. }\end{array}$ & $\begin{array}{l}\text { Introduced direct benefit } \\
\text { transfer in fertiliser subsidy to } \\
\text { increase efficiency and } \\
\text { strengthen fertiliser supply } \\
\text { chain. } \\
\text { Apply integrated nutrient } \\
\text { management with emphasis } \\
\text { on organic fertilisers. } \\
\text { Authors calculated with some } \\
\text { assumptions that total benefits } \\
\text { with soil health mapping and } \\
\text { soil test based fertiliser } \\
\text { recommendations along with } \\
\text { improved practices will be Rs. } \\
4.33 \text { lakh, while the cost was } \\
\text { estimated at Rs } 0.254 \text { lakh } \\
\text { crore. The benefit-cost ratio } \\
\text { would be } 17: 1 \text {. In addition to } \\
\text { economic benefits, there } \\
\text { would be several environment } \\
\text { be ne fits, e m p loy m ent } \\
\text { generation, and enhanced } \\
\text { sustainability of Indian } \\
\text { agriculture. }\end{array}$ \\
\hline
\end{tabular}




\begin{tabular}{|c|c|c|c|c|}
\hline No & Reference & Context & Methodology & Analysis \\
\hline 3 & \multicolumn{4}{|c|}{$\begin{array}{l}\text { Dynamics of soil fertility management practices in semi-arid regions: A case study of } \\
\text { AP }\end{array}$} \\
\hline & $\begin{array}{l}\text { B Suresh Reddy } \\
- \\
\text { EPW }\end{array}$ & Andhra Pradesh & $\begin{array}{l}\text { A total of } 360 \text { farmers } \\
\text { were gathered from } \\
\text { three district of AP } \\
\text { and were personally } \\
\text { interviewed using a } \\
\text { structured schedule } \\
\text { and ex post facto } \\
\text { research design } \\
\text { coupled with case } \\
\text { studies and PRA } \\
\text { methods. Secondary } \\
\text { d a t a w a s l s o } \\
\text { collected, Fertiliser } \\
\text { recommendations } \\
\text { were obtained. The } \\
\text { data gathered was } \\
\text { an alys ed using } \\
\text { average frequency } \\
\text { and percentages. The } \\
\text { Baletese \& Coelli } \\
\text { model was used to } \\
\text { calculate the average } \\
\text { technical efficiency. } \\
\text { A fter regression } \\
\text { a n a lys is using } \\
\text { frontier production } \\
\text { function, the average } \\
\text { TE was calculated. }\end{array}$ & 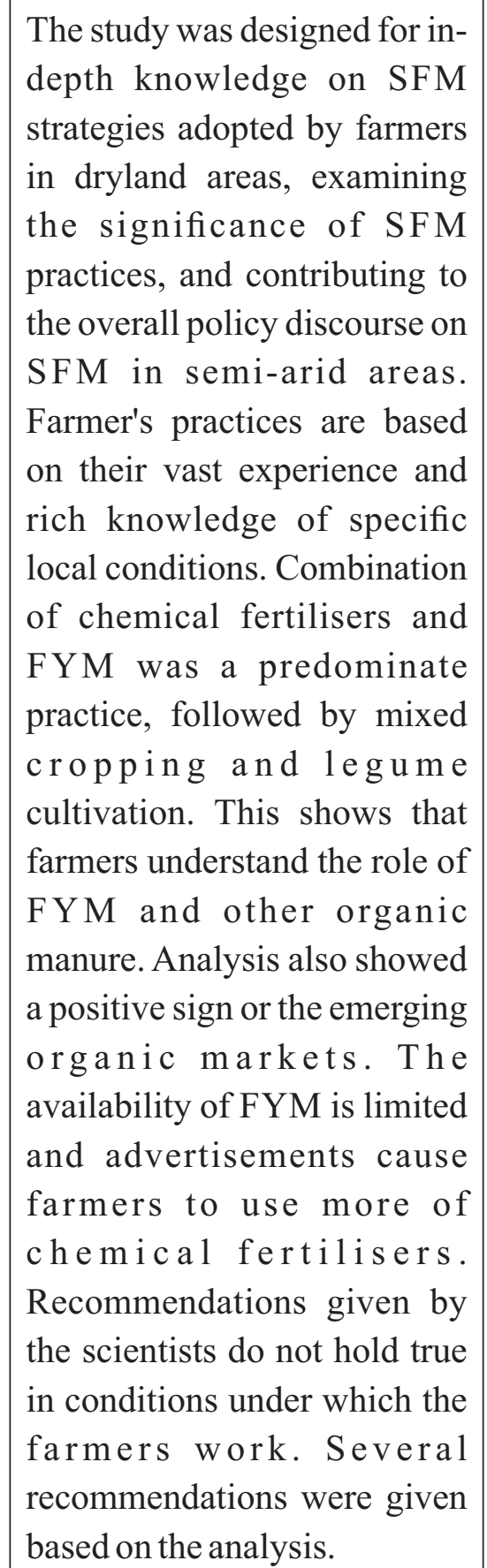 \\
\hline
\end{tabular}




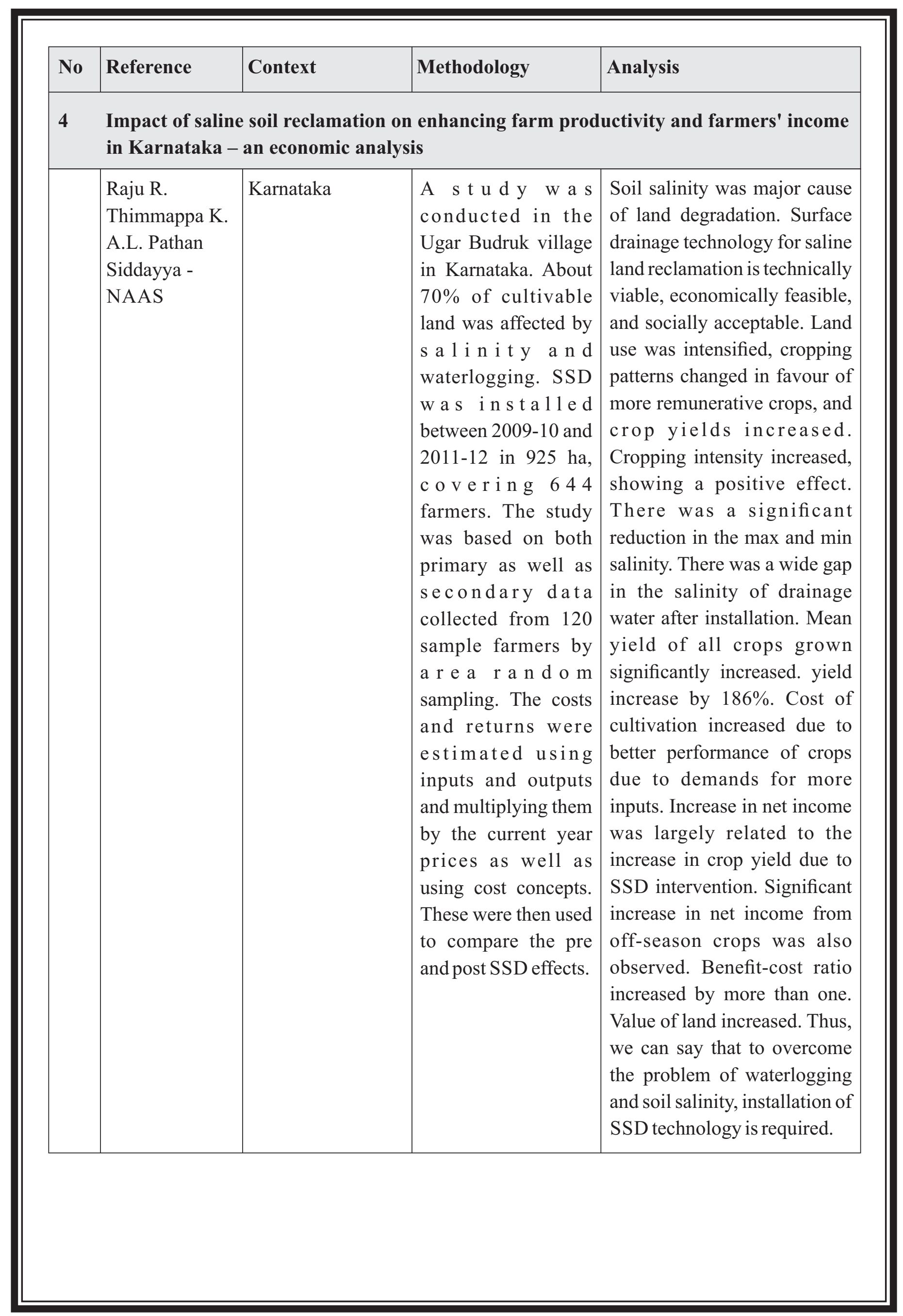




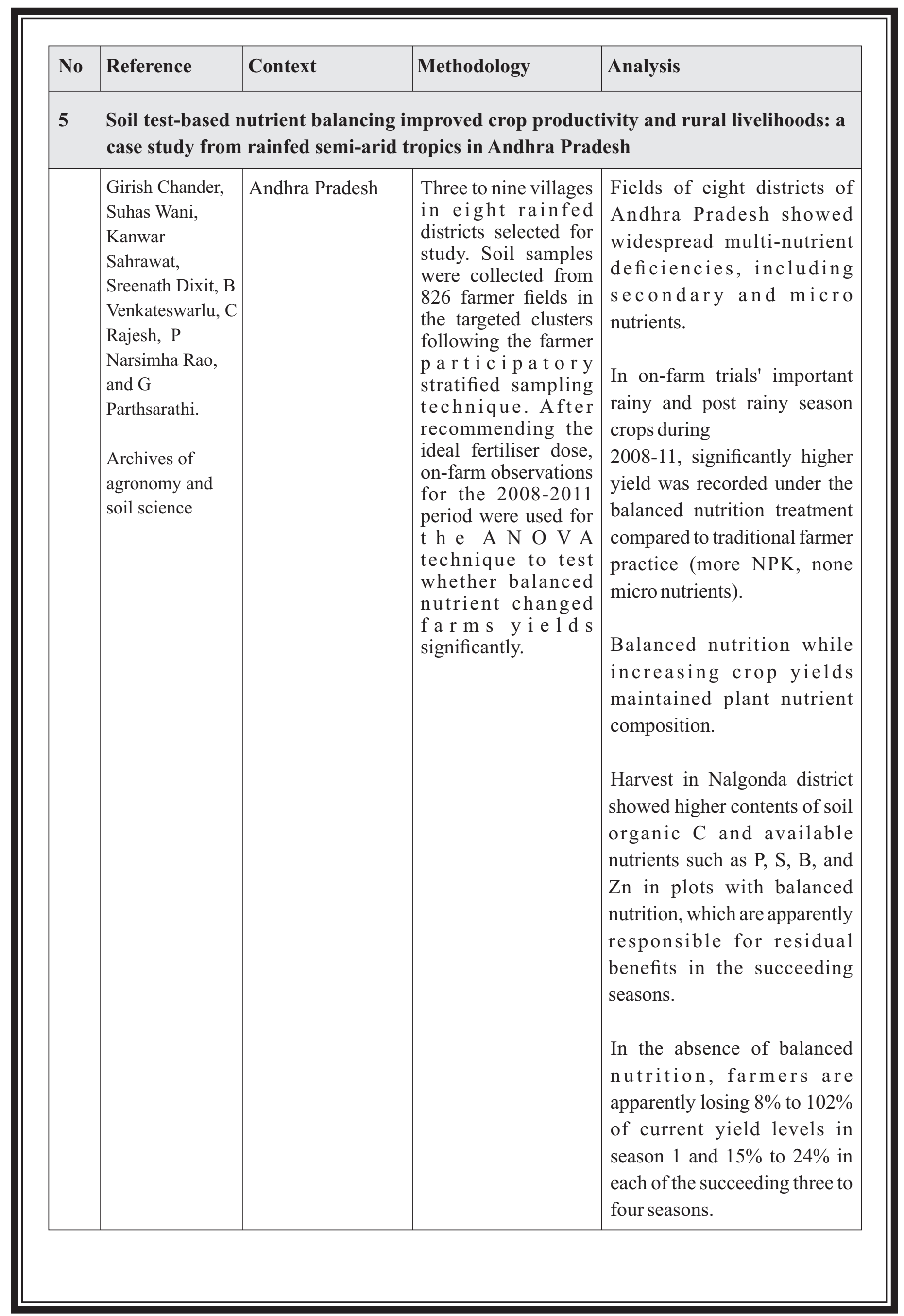




\section{National Policies on Soil Management}

\begin{tabular}{|c|c|c|c|}
\hline Plan & Years & Policies & Progress \\
\hline \multirow[t]{7}{*}{ 1st FYP } & $1951-1956$ & Soil conservation associatioans & $\begin{array}{l}1953 \text { - Central soil conservation board } \\
\text { set up }\end{array}$ \\
\hline & & $\begin{array}{l}\text { Establishment of a Soil } \\
\text { Conservation Branch at the Forest } \\
\text { Research Institute, Dehradun }\end{array}$ & Sum of about Rs. 1.6 crore was spent \\
\hline & & Soil and land utilisation survey & $\begin{array}{l}\text { Contour bunding and terracing of about } \\
700,000 \text { acres of agricultural lands }\end{array}$ \\
\hline & & $\begin{array}{l}\text { Soil conservation in community } \\
\text { development projects }\end{array}$ & $\begin{array}{l}\text { Desert Afforestation and Research Station } \\
\text { was set up at Jodhpur }\end{array}$ \\
\hline & & $\begin{array}{l}\text { Soil conservation in river valley } \\
\text { projectareas }\end{array}$ & $\begin{array}{l}\text { Eight regional research-cum-demonstration } \\
\text { centres were established }\end{array}$ \\
\hline & & \multicolumn{2}{|c|}{ Central Land Utilisation and Soil Conservation Organisation at the Centre } \\
\hline & & \multicolumn{2}{|c|}{ Land Utilisation and Soil Conservation Board in every State. } \\
\hline \multirow[t]{6}{*}{ 2nd FYP } & $1956-1961$ & $\begin{array}{l}\text { Training centres have been } \\
\text { established by the Government of } \\
\text { India at the research stations }\end{array}$ & Rs. 18 crore spent \\
\hline & & $\begin{array}{l}\text { Pilot project demonstration centres } \\
\text { to be established in different parts of } \\
\text { the country for giving } \\
\text { demonstrations of soil conservation } \\
\text { practices to farmers }\end{array}$ & $\begin{array}{l}\text { An area of } 2 \text { million acres covered under } \\
\text { contour bunding and terracing }\end{array}$ \\
\hline & & $\begin{array}{l}\text { Erosion control programmes should } \\
\text { therefore be accompanied by } \\
\text { appropriate programmes of } \\
\text { educationand resettlement }\end{array}$ & $\begin{array}{l}\text { An integrated all-India Soil Conservation } \\
\text { and Land Use Survey was initiated }\end{array}$ \\
\hline & & $\begin{array}{l}\text { Agency of the national extension } \\
\text { service }\end{array}$ & $\begin{array}{l}70 \text { officers and } 900 \text { assistants have been } \\
\text { trained }\end{array}$ \\
\hline & & $\begin{array}{l}\text { Village panchayat should become } \\
\text { responsible for soil conservation } \\
\text { measures and ensuring minimum } \\
\text { standards of land management by } \\
\text { individual cultivators. They should } \\
\text { also receive such technical and } \\
\text { financial assistance as may be } \\
\text { needed. }\end{array}$ & $\begin{array}{l}40 \text { demonstration projects, each covering } \\
\text { about } 1,000 \text { acres, were undertaken on a } \\
\text { catchment basis }\end{array}$ \\
\hline & & Central fertiliser pool & $\begin{array}{l}\text { The Desert Afforestation and Research } \\
\text { Station at Jodhpur was reorganised as a } \\
\text { Central Arid Zone Research Institute in } \\
\text { collaboration with UNESCO }\end{array}$ \\
\hline
\end{tabular}




\begin{tabular}{|c|c|c|c|}
\hline \multirow[t]{8}{*}{ 3rd FYP } & 1961- 1966 & $\begin{array}{l}\text { Intensive Agriculture Development } \\
\text { program (IADP) was the first major } \\
\text { experiment of the Indian } \\
\text { government in the field of } \\
\text { agriculture, and it was also known } \\
\text { as a "package programme" as it was } \\
\text { based on the package approach }\end{array}$ & $\begin{array}{l}\text { An area of } 1.9 \text { million hectares was } \\
\text { reclaimed }\end{array}$ \\
\hline & & River valley projects & $\begin{array}{l}\text { The work was initiated in } 13 \text { river valley } \\
\text { projects }\end{array}$ \\
\hline & & \multicolumn{2}{|l|}{ Reclamation of alkaline and usar lands } \\
\hline & & \multicolumn{2}{|c|}{ The Central Arid Zone Research Institute For desert reclamation } \\
\hline & & \multicolumn{2}{|c|}{$\begin{array}{l}\text { Empowering State Governments to frame soil conservation schemes for the basin } \\
\text { of a river or a stream or for groups of villages has been recommended }\end{array}$} \\
\hline & & \multicolumn{2}{|c|}{ The Fertiliser Distribution Enquiry Committee } \\
\hline & & \multicolumn{2}{|c|}{ A Central Fertiliser Marketing Corporation } \\
\hline & & \multicolumn{2}{|c|}{ Set up a Central Institute of Pedology and Soil Mechanics. } \\
\hline \multirow[t]{3}{*}{ 4th FYP } & $1969-1974$ & $\begin{array}{l}\text { Adopt an "area saturation" } \\
\text { approach so as to treat all types of } \\
\text { land on a complete watershed basis. }\end{array}$ & $\begin{array}{l}\text { The chemical fertilisers in terms of } \\
\text { nitrogenous and phosphatic recorded } 10.58 \\
\text { lakh and } 4.1 \text { lakh tones, respectively, ending } \\
\text { in 1973-74 }\end{array}$ \\
\hline & & $\begin{array}{l}\text { A resource inventory unit was } \\
\text { established at the centre during } \\
1966-67\end{array}$ & $\begin{array}{l}\text { At the end of } 1968-69 \text {, there were } 65 \text { soil- } \\
\text { testing laboratories all over the country with } \\
\text { a total annual capacity of handling } 1.08 \\
\text { million samples }\end{array}$ \\
\hline & & \multicolumn{2}{|c|}{ The scheme of soil conservation in the catchments of river valley projects } \\
\hline \multirow[t]{4}{*}{ 5th FYP } & $1974-1979$ & $\begin{array}{l}\text { Sharp increase in the prices of food, } \\
\text { fertilisers, and oil seriously upset } \\
\text { the assumption on which draft had } \\
\text { been framed }\end{array}$ & $\begin{array}{l}\text { The total coverage under soil and water } \\
\text { conservation was } 21.7 \text { million hectare in } \\
1977-78\end{array}$ \\
\hline & & $\begin{array}{l}\text { Soil and water conservation } \\
\text { programmes have also been taken } \\
\text { up with institutional credit support, } \\
\text { and the targets of physical } \\
\text { performance are likely to be } \\
\text { achieved. }\end{array}$ & $\begin{array}{l}\text { The area covered by soil conservation } \\
\text { measures is only } 23.40 \text { million hectares so } \\
\text { far. }\end{array}$ \\
\hline & & \multicolumn{2}{|c|}{$\begin{array}{l}\text { A centrally sponsored scheme of soil conservation in the catchments of river } \\
\text { valley project(RVP) was started }\end{array}$} \\
\hline & & \multicolumn{2}{|c|}{$\begin{array}{l}\text { Soil and water conservation programmes are being taken up on the watershed } \\
\text { approach }\end{array}$} \\
\hline
\end{tabular}




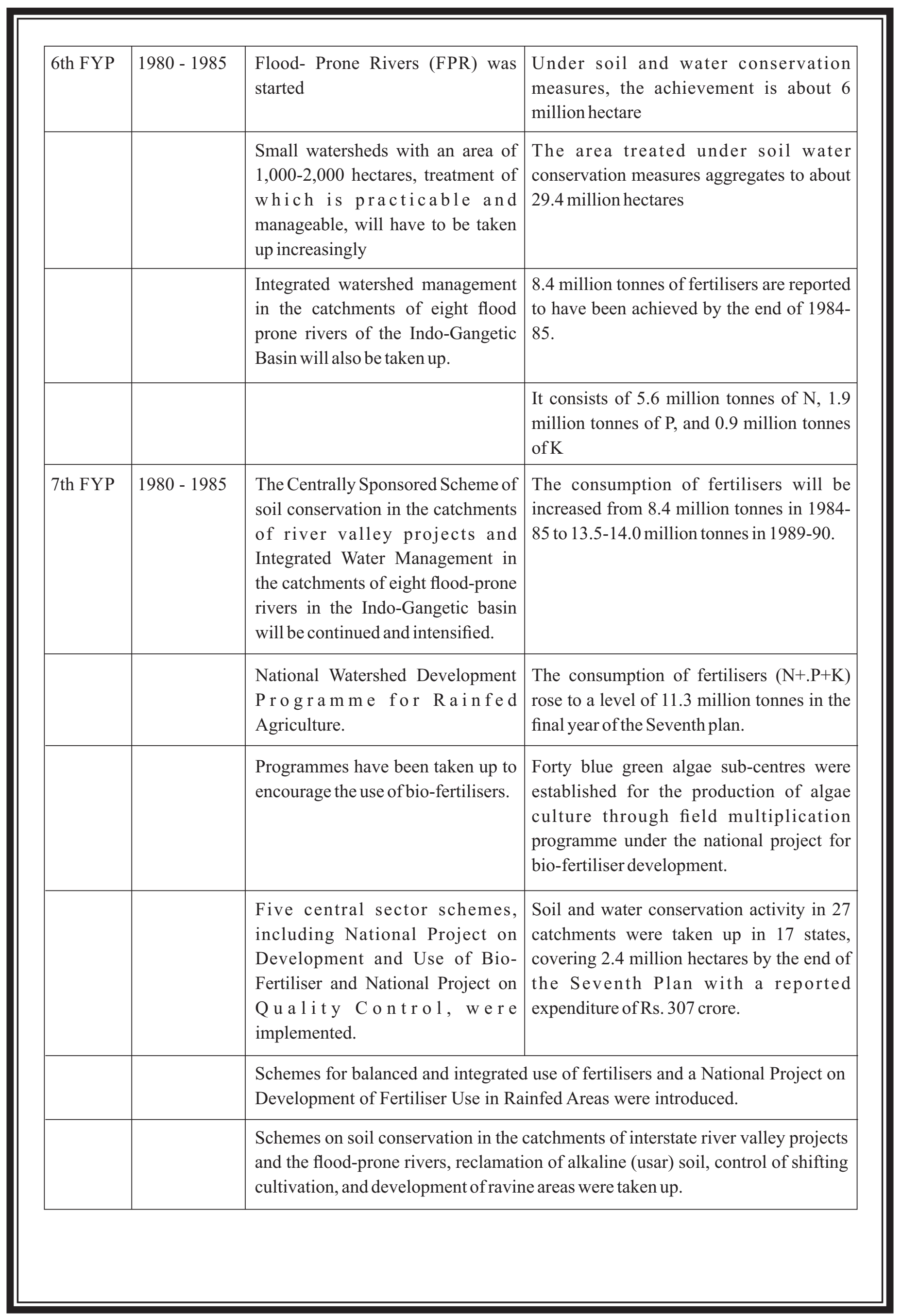




\begin{tabular}{|c|c|c|c|}
\hline 8th FYP & $1992-1997$ & $\begin{array}{l}\text { Efficient use of chemical fertilisers, } \\
\text { recycling of organic wastes, and use } \\
\text { of bio-fertilisers have an important } \\
\text { place in the sustainable agricultural } \\
\text { development process }\end{array}$ & $\begin{array}{l}\text { An amount of Rs } 40.826 \text { crore was released } \\
\text { to the States of the North-East region and } \\
0.67 \text { lakh ha. The area was treated through } \\
\text { treatment packages. }\end{array}$ \\
\hline & & $\begin{array}{l}\text { A centrally sponsored scheme of } \\
\text { reclamation of alkali soil was } \\
\text { continued from the seventh plan. }\end{array}$ & $\begin{array}{l}\text { The level of } 14.3 \text { million tonnes was } \\
\text { reached in 1996-97. }\end{array}$ \\
\hline & & $\begin{array}{l}\text { The scheme of Watershed } \\
\text { Development Project in Shifting } \\
\text { Cultivation Areas (WDPSCA) was } \\
\text { launched in seven north-eastern } \\
\text { states. }\end{array}$ & $\begin{array}{l}\text { Phosphatic and potassic fertilisers were } \\
\text { decontrolled in August 1992. Only urea } \\
\text { (nitrogenous fertiliser) continued to be } \\
\text { under the price control system and involves } \\
\text { a heavy subsidy for keeping the farm gate } \\
\text { prices low. }\end{array}$ \\
\hline & & $\begin{array}{l}\text { To make soil treatment cost- } \\
\text { effective, the guidelines } \\
\text { emphasised on the vegetative } \\
\text { conservation measures with active } \\
\text { involvement of the beneficiaries } \\
\text { and the non-governmental } \\
\text { organisations (NGOs). }\end{array}$ & $\begin{array}{l}\text { The All India Soil and Land Use Survey has } \\
\text { covered } 1155.74 \text { lakh ha so far under } \\
\text { priority delineation survey and } 85.65 \text { lakh } \\
\text { ha under detailed soil survey. }\end{array}$ \\
\hline & & $\begin{array}{l}\text { The "Application of Remote } \\
\text { Sensing Technology for Soil Survey } \\
\text { and Land Use Planning" scheme. }\end{array}$ & $\begin{array}{l}\text { Up to the end of the Eighth Plan, only } 17.96 \\
\mathrm{~m} \text { ha had been covered/treated. }\end{array}$ \\
\hline & & \multicolumn{2}{|c|}{$\begin{array}{l}\text { Seventh Plan Centrally Sponsored Schemes of Soil Conservation in the } \\
\text { catchments of River Valley Projects (RVP) and Integrated Watershed } \\
\text { Management in the catchments of Flood Prone Rivers (FPR) were continued. }\end{array}$} \\
\hline \multirow[t]{4}{*}{ 9th FYP } & $1997-2002$ & $\begin{array}{l}\text { Community and village institutions } \\
\text { will be encouraged to participate in } \\
\text { protecting natural resources from } \\
\text { degradation. }\end{array}$ & $\begin{array}{l}1.5 \text { lakh ha. has been treated with an } \\
\text { expenditure of Rs } 82 \text { crore under watershed } \\
\text { management. }\end{array}$ \\
\hline & & $\begin{array}{l}\text { Programmes for regeneration of } \\
\text { land and water resources will be } \\
\text { strengthened }\end{array}$ & $\begin{array}{l}\text { An area of } 0.60 \mathrm{~m} . \text { ha. Out of } 3.5 \mathrm{~m} . \text { ha. of } \\
\text { alkali, land has been reclaimed until the end } \\
\text { of } 2002-03 \text {. }\end{array}$ \\
\hline & & \multicolumn{2}{|c|}{$\begin{array}{l}\text { Macro Management Mode brings together } 27 \text { centrally sponsored schemes under } \\
\text { one umbrella - Reclamation \& Development of Alkali \& Acid Soil (R\&DAAS) }\end{array}$} \\
\hline & & \multicolumn{2}{|c|}{$\begin{array}{l}\text { Centrally sponsored scheme of reclamation of alkali soil - extension of the scheme } \\
\text { to all other states of India was approved where alkali soil problems exist as per } \\
\text { scientific parameter. }\end{array}$} \\
\hline 10th FYP & $2002-2007$ & $\begin{array}{l}\text { Unsustainable practices such as } \\
\text { excessive use of water together with } \\
\text { imbalanced use of fertilisers were } \\
\text { seen. }\end{array}$ & $\begin{array}{l}\text { Around } 22 \text { million hectares of degraded } \\
\text { land was reportedly treated under these } \\
\text { various schemes at a cost of Rs. } 8,810 \text { crore. }\end{array}$ \\
\hline
\end{tabular}




\begin{tabular}{|l|l|l|l|}
\hline & & $\begin{array}{l}\text { A condition that a certain percentage of allotted land (say 40 or 50\%) must be } \\
\text { utilised for tree cover can be stipulated so as to increase the crown area for } \\
\text { improving the environmental and ecological conditions }\end{array}$ \\
\hline 11 th FYP $2007-2012$ & $\begin{array}{l}\text { Soil survey and land degradation mapping of the entire country would be } \\
\text { conducted from the Tenth Plan onwards in a mission mode approach. }\end{array}$ \\
\hline $\begin{array}{l}\text { Adoption of Integrated Nutrient Management (INM)/Integrated Plant Nutrient } \\
\text { Supply (IPNS) }\end{array}$ & $\begin{array}{l}\text { The Centre introduced a new } \\
\text { scheme, the 'National Project on } \\
\text { Management of Soil Health \& } \\
\text { Fertility' (NPMSH\&F). }\end{array}$ & $\begin{array}{l}\text { Fertiliser consumption rose over } 30 \% \\
\text { during the Eleventh Plan, the main reason } \\
\text { and feedstock doubled since 2006 }\end{array}$ \\
\hline 12 th FYP $2012-2017$ & $\begin{array}{l}\text { Soil health cards and strengthening } \\
\text { of soil testing labs and expanding } \\
\text { their testing capacity }\end{array}$ & $\begin{array}{l}\text { By 2010-11, there were 1,049 soil test labs } \\
\text { in the country with a soil analysis capacity } \\
\text { of 106 lakh soil samples per annum }\end{array}$ \\
\hline & $\begin{array}{l}\text { Minimum investment of Rs 36,000 crore in Natural Resources Management } \\
\text { (NRM) }\end{array}$ \\
\hline part ofthe National Action Plan on Climate Change (NAPCC) \\
\hline $\begin{array}{l}\text { Nutrient-based subsidy (NBS) system was adopted } \\
\text { The National Project on Management of Soil Health and Fertility and the Rainfed } \\
\text { Areas Development Programme (RADP) }\end{array}$ \\
\hline $\begin{array}{l}\text { Conservation agriculture (CA), integrated nutrient management, carbon } \\
\text { sequestration, erosion control, saline and alkaline soils management, legislation } \\
\text { for soil protection, development of remote sensing and GPS-based Decision } \\
\text { Support System (DSS), and amelioration of polluted soil are required to } \\
\text { rejuvenate deteriorated soils. }\end{array}$ \\
\hline
\end{tabular}


Regression analysis: Determinants of performance indicators of the SHC scheme (District level)

\section{Variables included in the district-level regression analysis}

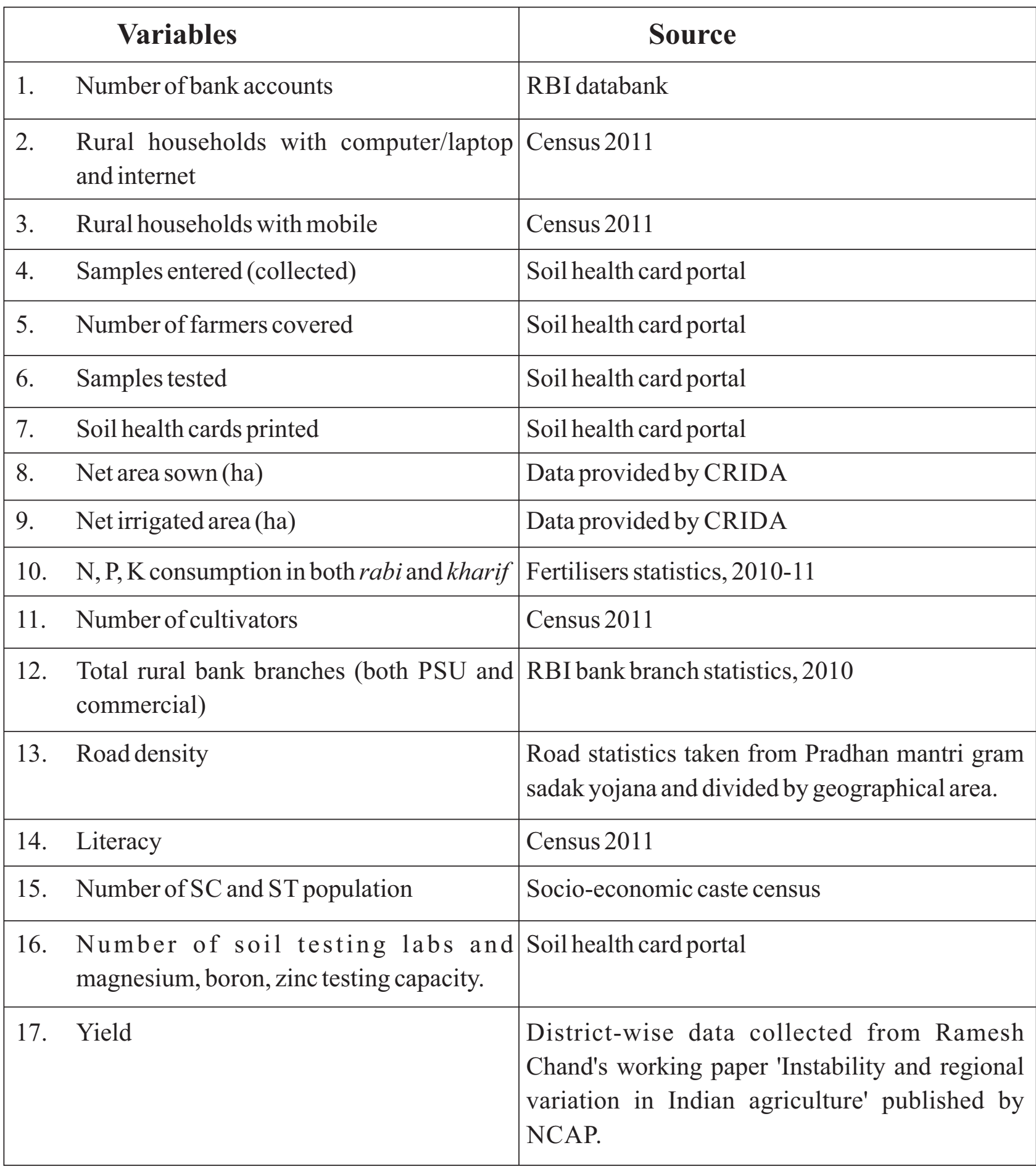




\section{Basic regression model:}

1) $\mathrm{Y}($ samples entered[collected] $)=\mathrm{f}($ number of bank accounts, households with computer and internet, households with mobile, net irrigated area, net sown area, total fertiliser consumption, rural bank branches, road density, literate population, number of SC and ST population, number oflabs)

\section{Determinants of samples collected (district level)}

\begin{tabular}{|l|r|r|}
\hline Dependent variable: samples collected & B & Significance level \\
\hline (Constant) & -1963 & .587 \\
\hline Total fertiliser use (Tonnes) & .233 & .000 \\
\hline No. of bank accounts & .032 & .000 \\
\hline Net sown area (ha) & .050 & .000 \\
\hline Net irrigated area (ha) & -.096 & .000 \\
\hline Households with computer/laptop an internet & -3.481 & .000 \\
\hline Households with mobile & .071 & .006 \\
\hline No. of labs & 1098.157 & .021 \\
\hline Total rural bank branches (both PSU and commercial) & 78.164 & .041 \\
\hline
\end{tabular}

2) $\mathrm{Y}$ (samples tested) $=\mathrm{f}$ (number of bank accounts, households with a computer and internet, households with mobile, net irrigated area, net sown area, total fertiliser consumption, rural bank branches, road density, literate population, number of SC and ST population, number of labs)

\section{Determinants of samples tested (district level)}

\begin{tabular}{|l|r|r|}
\hline Dependent variable: samples tested & B & Sig. \\
\hline (Constant) & -2577 & .438 \\
\hline Total fertiliser use (Tonnes) & .241 & .000 \\
\hline No. of bank accounts & .040 & .000 \\
\hline Net sown area (ha) & .039 & .000 \\
\hline Net irrigated area (ha) & -.102 & .000 \\
\hline Households with computer/laptop and internet & -3.286 & .000 \\
\hline Total rural bank branches (both PSU and commercial) & 88.392 & .013 \\
\hline Households with mobile & .052 & .030 \\
\hline
\end{tabular}

3) $\quad \mathrm{Y}$ (Soil health card printed $)=\mathrm{f}$ (number of bank accounts, households with computer and internet, households with mobile, net irrigated area, net sown area, total fertiliser consumption, rural bank branches, road density, literate population, number of SC and ST population, number of labs) 


\section{Determinants of SHCs printed (district level)}

\begin{tabular}{|l|r|r|}
\hline Y $=$ SHCs printed & B & Sig. \\
\hline (Constant) & 16000 & .133 \\
\hline No. of bank accounts & .126 & .000 \\
\hline Net sown area (ha) & .101 & .000 \\
\hline Total rural bank branches (both PSU and commercial) & 474.2 & .000 \\
\hline Net irrigated area (ha) & -.217 & .000 \\
\hline Total fertiliser use (Tonnes) & .288 & .021 \\
\hline
\end{tabular}


1. Farmer Questionnaire

\section{Farmer questionnaire}

Soil Health Card Scheme 2017

National Institute of Agricultural Extension Management (MANAGE), Hyderabad

\section{Section I: Household Details}

1. State

2. District

3. Block

4. Village

5. Name of the farmer:

Mobile No.

6. Social group: $\mathrm{FC} / \mathrm{OBC} / \mathrm{SC} / \mathrm{ST}$

7. Age:

8. Sex:

9. Family size: $\mathrm{M}-\quad$; F- $\quad$; C-

10. Number of family members working on the farm: M- ; F-

11. Education (no. of years of head of family):

12. Landholding

a. Irrigated area..........number of plots

b. Rainfed area......number of plots

13. Annual net income after deducting costs (Rs.)
a. Agriculture:
b. Livestock:
c. Labour:
d. Others:

\section{Section II: About soil health card}

14. Are you aware about soil health card? Y/N

15. Are you aware of the soil health card portal? $\mathrm{Y} / \mathrm{N}$

16. How many soil samples have been taken from your village?

17. Are the results discussed among farmers in the village? $\mathrm{Y} / \mathrm{N}$

18. Does the soil health card portal give useful information?

19. Details of soil health card scheme operation in your village. 
Section III: Initial activities under the SHC scheme

\begin{tabular}{|l|l|l|l|l|l|}
\hline Purpose & $\begin{array}{l}\text { Participation Number } \\
(\mathrm{Y} / \mathrm{N})\end{array}$ & $\begin{array}{l}\text { Distance } \\
\text { from village }\end{array}$ & $\begin{array}{l}\text { Number } \\
\text { of days }\end{array}$ & $\begin{array}{l}\text { Nature } \\
\text { of Inputs }\end{array}$ & $\begin{array}{l}\text { Benefits } \\
\text { if any }\end{array}$ \\
\hline Mobilisation (farmers) & \multicolumn{5}{|l|}{} \\
\hline Meetings conducted & & & & & \\
\hline Exposure visits & & & & & \\
\hline Trainings conducted & & & & \\
\hline
\end{tabular}

Section-IV Cropping Pattern (for all)

\begin{tabular}{|c|c|c|c|c|c|c|c|c|c|c|c|c|}
\hline Crop name & $\begin{array}{l}\text { Season } \\
\mathrm{K} / \mathrm{R} / \\
\text { annual }\end{array}$ & $\begin{array}{l}\text { Area } \\
\text { (acre) }\end{array}$ & $\begin{array}{l}\text { Yield } \\
\text { (per } \\
\text { care) }\end{array}$ & $\begin{array}{l}\text { Fertiliser } \\
\text { use Urea } \\
\text { (bags) }\end{array}$ & $\begin{array}{l}\text { DAP } \\
\text { (bags) }\end{array}$ & $\begin{array}{l}\text { MoP } \\
\text { (bags) }\end{array}$ & $\begin{array}{l}\text { Gypsum } \\
\text { (Kg) }\end{array}$ & $\begin{array}{l}\text { Micro } \\
\text { Nutrients } \\
(\mathrm{Kg})\end{array}$ & $\begin{array}{l}\text { Bio- } \\
\text { fertili } \\
\text { sers } \\
(\mathrm{Kg})\end{array}$ & $\begin{array}{l}\text { Liming } \\
\text { material } \\
(\mathrm{Kg})\end{array}$ & Others & $\begin{array}{l}\text { Total } \\
\text { Cost }\end{array}$ \\
\hline $\begin{array}{l}\text { Before } \\
\text { SHC } \\
\text { scheme }\end{array}$ & & & & & & & & & & & & \\
\hline Crop 1 & & & & & & & & & & & & \\
\hline Crop 2 & & & & & & & & & & & & \\
\hline Crop 3 & & & & & & & & & & & & \\
\hline $\begin{array}{l}\text { Last year } \\
2016-17\end{array}$ & & & & & & & & & & & & \\
\hline Crop 1 & & & & & & & & & & & & \\
\hline Crop 2 & & & & & & & & & & & & \\
\hline Crop 3 & & & & & & & & & & & & \\
\hline
\end{tabular}

\section{Section V: Soil Health Card holders}

20. Are you having a soil health card? $\mathrm{Y} / \mathrm{N}$

If yes

21. In which month and year was soil testing done?

22. In which year and month did you get the SHC?

23. From where did you get the SHC?

24. Are you able to understand the information in the soil health card? Y/N

25. Are you using fertilisers and micro nutrients as per the SHC? Y/N

26. Have you received any financial assistance from the government? Y/N

27. If you are not following recommendation, why is that?

28. How many of your plots are covered for soil testing?

One / none /some/all

29. Are the recommendations suitable for all your plots?

$\mathrm{Y} / \mathrm{N}$

30. How many soil samples were taken from your farm?

31. Do you think the samples represent all the soil types in your farm? Y/N

32. If no, how many samples are required? 
33. Are the results provided in time? Y/N

34. Did the agricultural extension worker explain the content of SHC? Y/N

35. Who informed you about the content of SHC?
a. KVK
b. Agricultural Extension Officer/Agricultural Officer
c. Scientist of SAU/ICAR
d. NGOs

36. Are the recommendations practical? Y / N

37. Are the recommended inputs easily available in the market?

38. Did you face any difficulties in adopting the practices? Y/N

Section 4: Perception of the SHC scheme

39. What is the main benefit (s) from SHC?

40. Would you like to suggest any improvement to the SHC system? Y/N

41. If yes, provide details.

42. Would you like to take your soils to private testing labs? Y/N

43. Are you willing to pay for the soil health card?

44. Observations from the investigators.

45. Name of the investigator. 
State-wise fund released and unspent balance under the Soil Health Card scheme

(As on 30.01.2017)

(Rs. In lakh)

\begin{tabular}{|c|c|c|c|c|c|c|c|c|c|c|c|c|c|c|}
\hline \multirow[t]{3}{*}{ State } & \multicolumn{3}{|c|}{$\begin{array}{c}2014- \\
15\end{array}$} & \multicolumn{4}{|c|}{ 2015-16 } & \multicolumn{4}{|c|}{ 2016-17 } & \multicolumn{3}{|c|}{ Total } \\
\hline & \multirow{2}{*}{ Released } & UC & UC & \multirow{2}{*}{$\begin{array}{c}\text { Allocatio } \\
n\end{array}$} & \multirow{2}{*}{$\begin{array}{c}\text { Releas } \\
\text { ed }\end{array}$} & UC & UC & \multirow{2}{*}{$\begin{array}{c}\text { Allocatio } \\
n\end{array}$} & \multirow{2}{*}{$\begin{array}{c}\text { Release } \\
\text { d }\end{array}$} & UC & UC & $\begin{array}{c}\text { Release } \\
\mathrm{d}\end{array}$ & UC & UC \\
\hline & & $\begin{array}{c}\text { Receive } \\
\text { d }\end{array}$ & $\begin{array}{c}\text { Pendin } \\
\mathrm{g}\end{array}$ & & & Received & $\begin{array}{c}\text { pendin } \\
\mathrm{g}\end{array}$ & & & $\begin{array}{c}\text { Receive } \\
\mathrm{d}\end{array}$ & $\begin{array}{c}\text { pendin } \\
\mathrm{g}\end{array}$ & & $\begin{array}{c}\text { Receive } \\
\text { d }\end{array}$ & Pending \\
\hline Andhra Pr. & 124 & 124 & 0 & 706 & 458 & 458 & 0 & 1394 & 697 & 0 & 697 & 1279 & 582 & 697 \\
\hline Arunachal Pr. & 12 & 12 & 0 & 30 & 17 & 17 & 0 & 50 & 0 & 0 & 0 & 29 & 29 & 0 \\
\hline Assam & 51 & 0 & 51 & 253 & 142 & 3 & 139 & 619 & 0 & 0 & 0 & 193 & 3 & 190 \\
\hline Bihar & 253 & 150 & 103 & 674 & 488 & 240 & 248 & 1289 & 0 & 0 & 0 & 742 & 390 & 351 \\
\hline Chhattisgarh & 66 & 66 & 0 & 383 & 281 & 195 & 86 & 685 & 343 & 0 & 343 & 690 & 261 & 429 \\
\hline Goa & 12 & 0 & 12 & 17 & 12 & 0 & 12 & 19 & 0 & 0 & 0 & 24 & 0 & 24 \\
\hline Gujarat & 81 & 81 & 0 & 836 & 603 & 420 & 184 & 1057 & 529 & 0 & 529 & 1213 & 501 & 712 \\
\hline Haryana & 34 & 17 & 18 & 401 & 288 & 210 & 78 & 440 & 0 & 0 & 0 & 322 & 227 & 96 \\
\hline Himachal Pr. & 24 & 24 & 0 & 71 & 47 & 47 & 0 & 59 & 29 & 0 & 29 & 101 & 71 & 29 \\
\hline J \& K & 32 & 0 & 32 & 141 & 77 & 49 & 28 & 326 & 0 & 0 & 0 & 109 & 49 & 60 \\
\hline Jharkhand & 51 & 36 & 15 & 73 & 54 & 31 & 23 & 128 & 64 & 0 & 64 & 169 & 66 & 103 \\
\hline Karnataka & 127 & 101 & 26 & 894 & 650 & 650 & 0 & 2060 & 1030 & 649 & 381 & 1807 & 1400 & 407 \\
\hline Kerala & 113 & 0 & 113 & 83 & 61 & 0 & 61 & 132 & 0 & 0 & 0 & 174 & 0 & 174 \\
\hline Madhya Pr. & 143 & 99 & 44 & 1228 & 888 & 465 & 423 & 2747 & 1374 & 329 & 1044 & 2404 & 894 & 1511 \\
\hline Maharashtra & 216 & 216 & 0 & 1285 & 932 & 932 & 0 & 2430 & 1215 & 1215 & 0 & 2363 & 2363 & 0 \\
\hline Manipur & 13 & 13 & 0 & 31 & 18 & 12 & 6 & 63 & 0 & 0 & 0 & 30 & 25 & 6 \\
\hline Meghalaya & 14 & 0 & 14 & 36 & 21 & 0 & 21 & 43 & 0 & 0 & 0 & 34 & 0 & 34 \\
\hline Mizoram & 12 & 0 & 12 & 24 & 14 & 14 & 0 & 36 & 0 & 0 & 0 & 26 & 14 & 12 \\
\hline Nagaland & 13 & 13 & 0 & 40 & 22 & 22 & 0 & 74 & 0 & 0 & 0 & 36 & 36 & 0 \\
\hline Odisha & 80 & 80 & 0 & 371 & 270 & 121 & 148 & 609 & 304 & 304 & 0 & 655 & 506 & 148 \\
\hline Punjab & 26 & 0 & 26 & 424 & 305 & 0 & 305 & 958 & 0 & 0 & 0 & 331 & 0 & 331 \\
\hline Rajasthan & 143 & 143 & 0 & 1213 & 876 & 90 & 786 & 2217 & 1108 & 0 & 1108 & 2128 & 233 & 1894 \\
\hline Sikkim & 12 & 12 & 0 & 20 & 12 & 8 & 4 & 25 & 0 & 0 & 0 & 24 & 20 & 4 \\
\hline Tamil Nadu & 132 & 132 & 0 & 652 & 470 & 470 & 0 & 1290 & 645 & 0 & 645 & 1246 & 601 & 645 \\
\hline Telangana & 93 & 93 & 0 & 544 & 353 & 353 & 0 & 937 & 468 & 0 & 468 & 915 & 446 & 468 \\
\hline \begin{tabular}{|l} 
Tripura \\
\end{tabular} & 18 & 18 & 0 & 40 & 23 & 23 & 0 & 79 & 0 & 0 & 0 & 41 & 41 & 0 \\
\hline Uttar Pr. & 354 & 354 & 0 & 2387 & 1716 & 282 & 1434 & 4884 & 2442 & 0 & 2442 & 4513 & 637 & 3876 \\
\hline Uttarakhand & 23 & 23 & 0 & 119 & 65 & 44 & 22 & 236 & 0 & 0 & 0 & 89 & 67 & 22 \\
\hline West Bengal & 117 & 117 & 0 & 667 & 480 & 480 & 0 & 1460 & 0 & 0 & 0 & 597 & 597 & 0 \\
\hline Total & 2390 & 1926 & 464 & 13642 & 9644 & 5636 & 4008 & 26346 & 10249 & 2497 & 7751 & 22282 & 10059 & 12223 \\
\hline
\end{tabular}




\section{Soil Health Card}

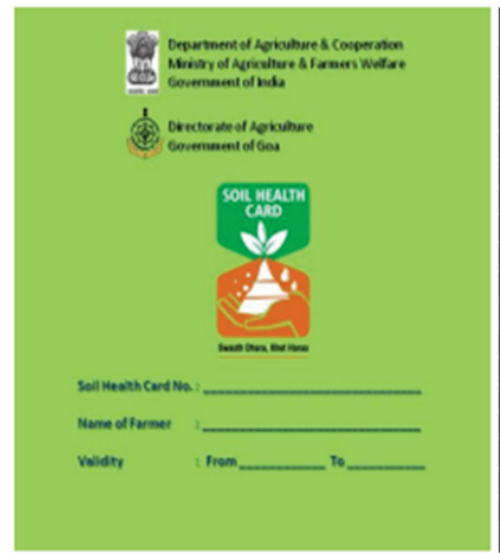

\begin{tabular}{|c|c|c|c|c|c|c|c|}
\hline \multicolumn{2}{|c|}{ SOIL HEALTH CARD } & \multirow{2}{*}{\multicolumn{2}{|c|}{$\begin{array}{c}\text { Name of } \\
\text { Laboratory }\end{array}$}} & & & & \\
\hline \multicolumn{2}{|r|}{ Farmer's Details } & & & & & & \\
\hline Name & & \multirow{2}{*}{\multicolumn{6}{|c|}{ SOIL TEST RESULTS }} \\
\hline \multicolumn{2}{|l|}{ Address } & & & & & & \\
\hline Village & & S. & \multirow{2}{*}{\multicolumn{2}{|c|}{ Parameter }} & \multirow{2}{*}{$\begin{array}{l}\text { Test } \\
\text { Value }\end{array}$} & \multirow[t]{2}{*}{ Unit } & \multirow{2}{*}{ Rating } \\
\hline Sub-District & & No. & & & & & \\
\hline District & & 1 & $\mathrm{pH}$ & & & & \\
\hline PIN & & 2 & EC & & & & \\
\hline Aadhaar Number & & 3 & Orga & c Carbon $(O C)$ & & & \\
\hline Mobile Number & & 4 & Avail & le Nitrogen $(\mathrm{N})$ & & & \\
\hline \multicolumn{2}{|c|}{ Soil Sample Details } & 5 & Avail & le Phosphorus (P) & & & \\
\hline Soll Sample Number & & 6 & Avail. & le Potassium (K) & & & \\
\hline Sample Collected on & & 7 & Avail & le Sulphur (S) & & & \\
\hline Survey No. & & 8 & Avail & le Zinc $(Z n)$ & & & \\
\hline Khasra No. / Dag No. & & 9 & Avail & le Boron (B) & & & \\
\hline Farm Size & & 10 & Avail & ple Iron (Fe) & & & \\
\hline Geo Position (GPS) & \begin{tabular}{|l|} 
Longitude: \\
\end{tabular} & 11 & Avail & le Manganese (Mn) & & & \\
\hline Irrigated / Rainfed & & 12 & Avail & le Copper (Cu) & & & \\
\hline
\end{tabular}

\begin{tabular}{|c|c|c|c|}
\hline \multicolumn{3}{|c|}{ Secondary \& Micro Nutrients Recommendations } & \\
\hline $\begin{array}{l}\text { St. } \\
\text { No. }\end{array}$ & \multicolumn{2}{|c|}{ Parameter } & $\begin{array}{l}\text { Recommendations } \\
\text { for Soil Applications }\end{array}$ \\
\hline 1 & \multicolumn{2}{|l|}{ Sulphur (S) } & \\
\hline 2 & \multicolumn{2}{|l|}{$\operatorname{Zinc}(\mathrm{Zn})$} & \\
\hline 3 & \multicolumn{2}{|l|}{ Boron (B) } & \\
\hline 4 & \multicolumn{2}{|l|}{$\operatorname{Iron}(\mathrm{Fe})$} & \\
\hline 5 & \multicolumn{2}{|c|}{ Manganese (Mn) } & \\
\hline 6 & \multicolumn{2}{|c|}{ Copper (Cu) } & \\
\hline \multicolumn{4}{|c|}{ General Recommendations } \\
\hline 1 & \multicolumn{2}{|c|}{ Organic Manure } & \\
\hline 2 & \multicolumn{2}{|c|}{ Biofertiliser } & \\
\hline 3 & \multicolumn{2}{|c|}{ Lime / Gypsum } & \\
\hline \multicolumn{2}{|c|}{$\begin{array}{l}\text { International } \\
\text { Year of Soils }\end{array}$} & & $\begin{array}{l}\text { Healthy Soils } \\
\text { for } \\
\text { a Healthy Life }\end{array}$ \\
\hline
\end{tabular}

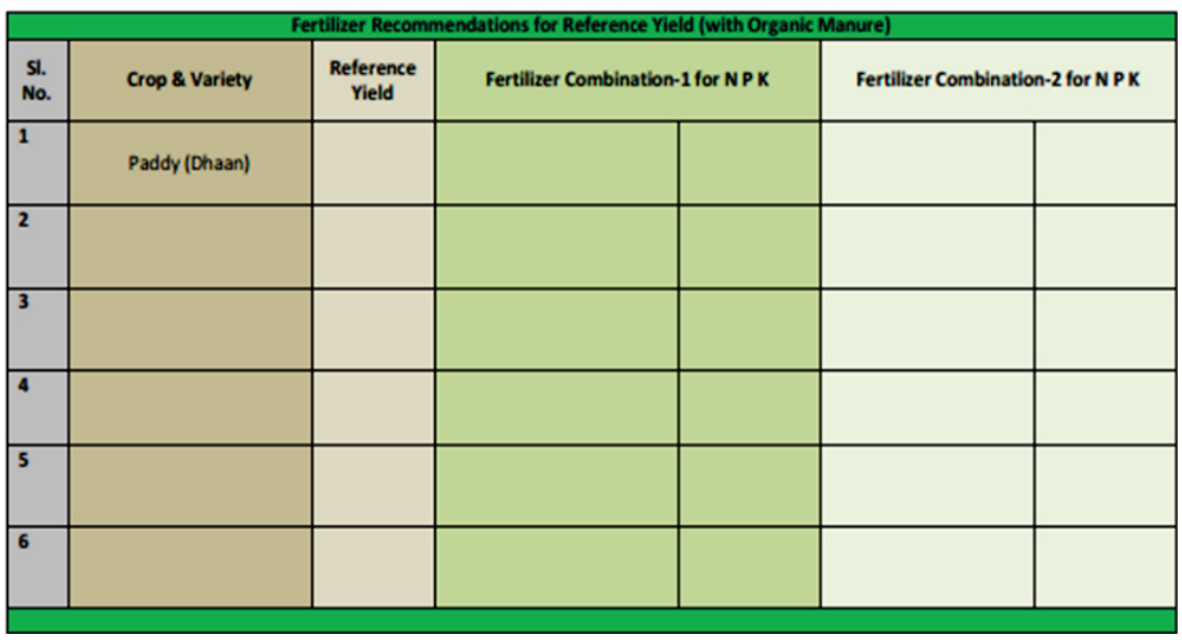


